\title{
Preliminary Siting Characterization Salt Disposition Facility - Site
} B

by

D. Wyatt

Westinghouse Savannah River Company

Savannah River Site

Aiken, South Carolina 29808

F. H. Syms

This paper was prepared in connection with work done under the above contract number with the U.S. Department of Energy. By acceptance of this paper, the publisher and/or recipient acknowledges the U.S. Government's right to retain a nonexclusive, royalty-free license in and to any copyright covering this paper, along with the right to reproduce and to authorize others to reproduce all or part of the copyrighted paper. 
K-TRT-S-00001

Rev. 0

July 1999

\section{Preliminary Siting Characterization Salt Disposition Facility - Site B (U)}

Site Geotechnical Services Department

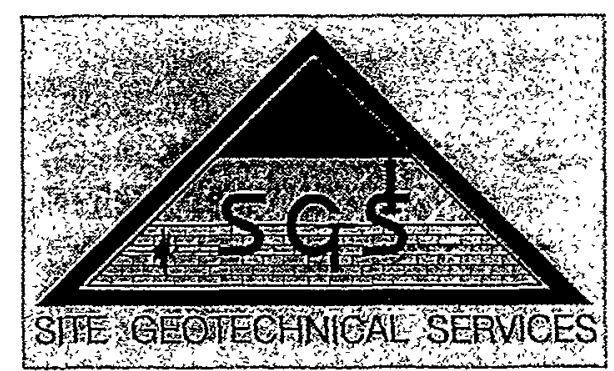

Westinghouse Savannah River Company Savannah River Site Aiken, SC 29808

Prepared for the U.S. Department of Energy Under Contract No. DE-AC09-96SR18500 


\section{DISCLAIMER}

Portions of this document may be illegible in electronic image products. Images are produced from the best available original document. 
Project:

Salt Disposition Facility

Document:

K-TRT-S-00001, Rev. 0

Title:

Preliminary Siting Characterization

Salt Disposition Facility - Site B (U)

Prepared by:

D. E.Wyatt, Situc Charecterization, SGS Department
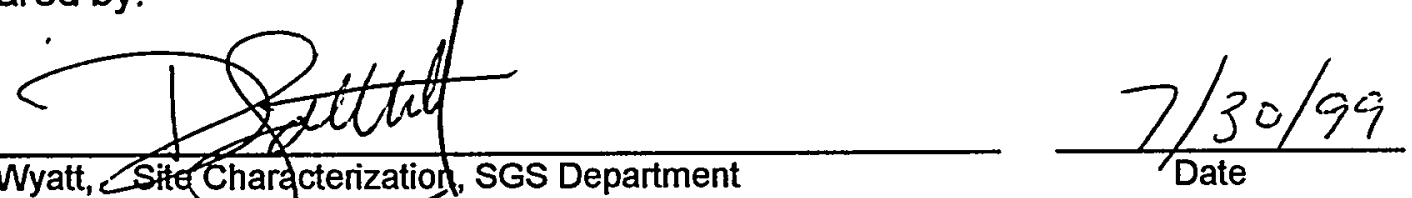

F.H. Syms, Geotechnicarf Ergineering, SGS Department

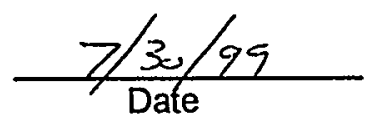

Approvals:

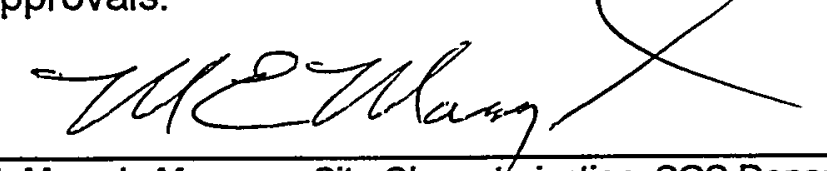

M. Maryak, Manager, Site Characterization, SGS Department
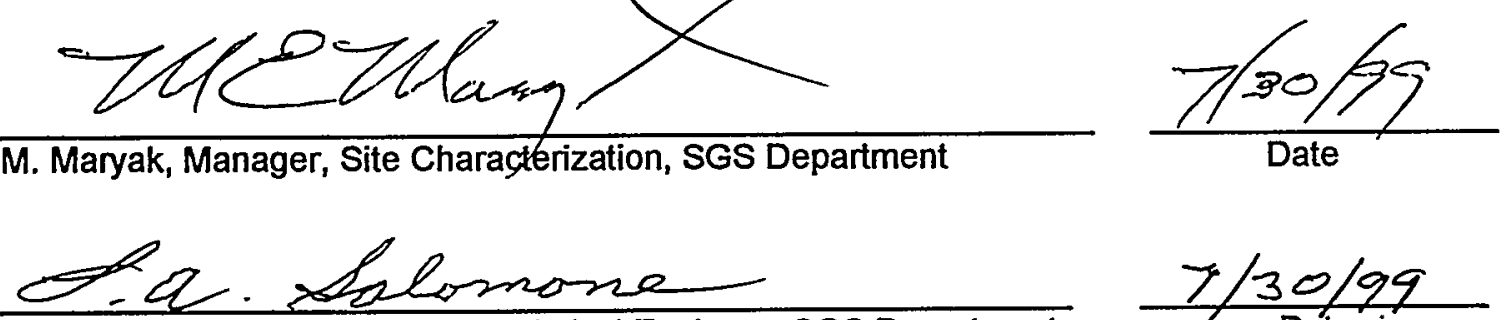

L. A. Salomone, Site Chief Geotechnical Engineer, SGS Department

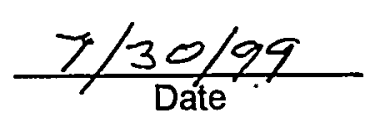




\section{DISCLAIMER}

This report was prepared as an account of work sponsored by an agency of the United States Government. Neither the United States Government nor any agency thereof, nor any of their employees, makes any warranty, express or implied, or assumes any legal liability or responsibility for the accuracy, completeness, or usefulness of any information, apparatus, product, or process disclosed, or represents that its use would not infringe privately owned rights. Reference herein to any specific commercial product, process, or service by trade name, trademark, manufacturer, or otherwise does not necessarily constitute or imply its endorsement, recommendation, or favoring by the United States Government or any agency thereof. The views and opinions of authors expressed herein do not necessarily state or reflect those of the United States Government or any agency thereof.

This report has been reproduced directly from the best available copy.

Available to DOE and DOE contractors from the Office of Scientific and Technical Information, P.O. Box 62, Oak Ridge, TN 37831; prices available from (615) 576-8401.

Available to the public from the National Technical Information Service, U.S. Department of Commerce; 5285 Port Royal Road, Springfield, VA 22161. 


\section{TABLE OF CONTENTS}

TABLE OF CONTENTS .. $v$

LIST OF TABLES vi

LIST OF FIGURES vi

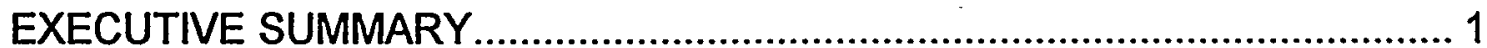

1 INTRODUCTION

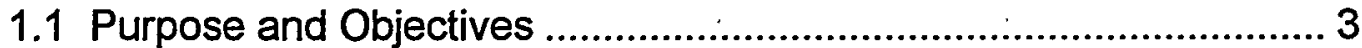

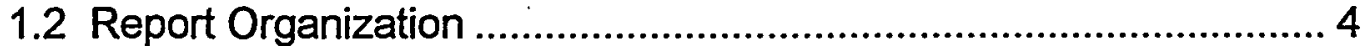

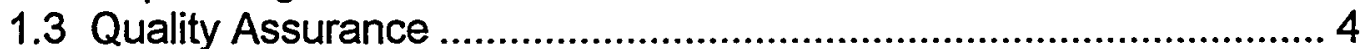

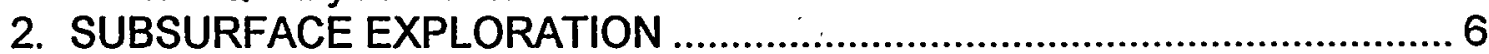

2.1 Field Test Location and Clearance ............................................. 6

2.2 Equipment and Field Test Methods ............................................... 7

2.2.1 Exploration Contractor(s) and Equipment.............................. 7

2.2.2 Standard Penetration Test (SPT) .......................................... 8

2.2.3 Undisturbed Sampling ......................................................... 9

2.2.4 Piezocone Penetration Test Soundings (CPTU)....................... 9

2.2.5 Borehole and Penetration Abandonment................................ 9

2.3 Sample Preparation, Handling, Storage, Transportation, Control... 10 3. SUBSURFACE CONDITIONS ............................................................ 11

3.1 Regional Geological Evaluation................................................ 11

3.2 The Atlantic Coastal Plain Stratigraphy Underlying Site B.............. 11

3.3 Basement Geology Underlying Site B ........................................ 13

3.4 Geological Structure Underlying Site B .................................... 13

3.5 Engineering Stratigraphy ........................................................ 14

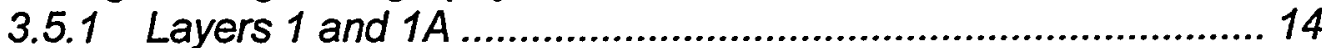

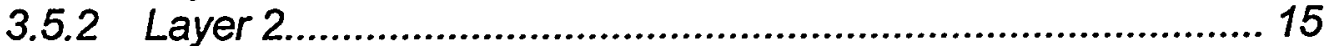

3.5.3 Layers 3 and $3 A$.............................................................. 15

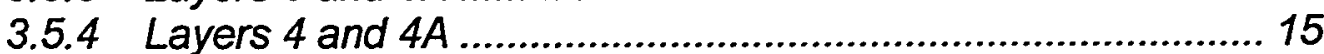

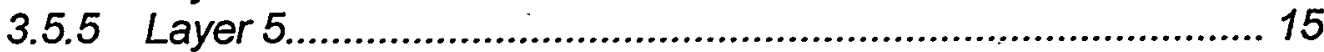

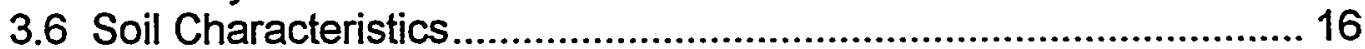

3.7 Soft Zone Characteristics ....................................................... 16

3.8 Groundwater Conditions........................................................... 17

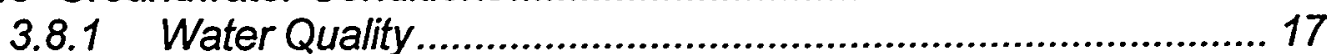

3.9 Topography and Surface Hydrology .............................................. 18

4. GEOTECHNICAL AND FOUNDATION ASSESSMENT .......................... 19

5. CONCLUSIONS AND RECOMMENDATIONS .......................................20

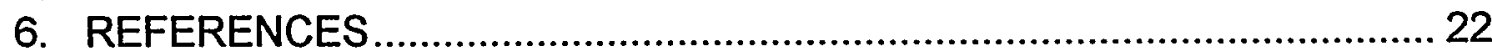




\section{LIST OF TABLES}

Table 1.1-1 Geotechnical Siting Criteria.......................................4

Table 3.5-1 Engineering Layer Horizon Picks....................................23

Table 3.5-2 Average Soil Parameters...........................................24

\section{LIST OF FIGURES}

Figure 0-1 Location of Site B Relative to $\mathrm{H}$ and $\mathrm{S}$ Areas......................25

Figure 1.0-1 Location of Boring SDFB-B1 and CPT's on Site B Footprint.........26

Figure 3.0-1 Correlation Tie Line from SDB-B1 to Well P-27 ...................27

Figure 3.0-2 Correlation Panel, P-27 to SDFB-B1 .............................28

Figure 3.0-3 Correlation Between CPTs C1 and C5 and SDFB-B1 .............29

Figure 3.2-1 Generalized Coastal Plain Stratigraphy .............................30

Figure 3.2-2 Photograph of Subsurface Sediments...............................31

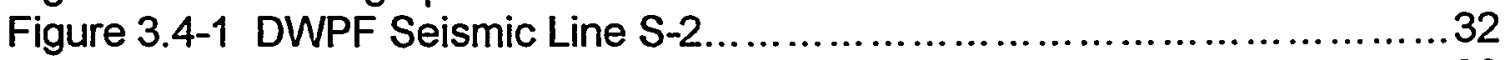

Figure $3.4-2$ DWPF Seismic Line S-7 ........................................ 33

Figure 3.4-3 Engineering Layer Three-Dimensional Model.......................34

Figure 3.4-4 CPT Cross-Section A - A' ....................................... 35

Figure 3.4-5 Three-dimensional Model of Tip Stress from the CPT Data.........36

Figure 3.4-6 Three-dimensional Model of Friction Ratio from the CPT Data.....37

Figure 3.6-1 Average Shear Wave Velocity from the CPT Data...................38

Figure 3.6-2 Average Tip Stress from the CPT Data .............................39

Figure 3.6-3 Average Friction Ratio from the CPT Data .......................40

Figure 3.6-4 Average $\mathrm{N}$-Values from the CPT Data ............................41

Figure 3.7-1 Interpreted Soft Zones from the CPT Data ........................44

Figure 3.8-1 Historical Water Table Elevation In Well SBG-4...................43

\section{APPENDICES}

Appendix A Boring Logs

Appendix B Seismic Cone Penetrometer Test Data

Appendix C Resistivity Cone Penetrometer Test data

Appendix D Laboratory Test Data

Appendix E Groundwater Sample Analysis 


\section{EXECUTIVE SUMMARY}

A siting and reconnaissance geotechnical program has been completed in S-Area at the Savannah River Site (SRS) in South Carolina. This program investigated the subsurface conditions for the area known as "Salt Disposition Facility (SDF), Site $B^{n}$ located northeast of $\mathrm{H}$-Area and within the S-Area (Figure 0-1). Data acquired from the Site $B$ investigation includes both field exploration and laboratory test data.

The purpose of the investigation was to obtain geotechnical information to characterize the subsurface conditions within the proposed Site B footprint. Specific characterization objectives included the preliminary definition of the engineering stratigraphy, a comparison of the continuity, thickness and relative elevation of stratigraphic units; a determination of the index properties of each stratigraphic layer; an evaluation of the presence, thickness and stratigraphic position of soft zones, if any; an evaluation of the presence, style, orientation, and age of potential faulting within the area, and an evaluation of the subsurface conditions in terms of relative geotechnical and foundation suitability. The field exploration scope completed for the SDF Site B investigation included: 6 Seismic Piezocone Penetrometer Test Soundings, 4 Resistivity Piezocone Penetrometer Soundings, 1 Standard Penetration Test Boring to 180 feet with laboratory index properties and coring from 180 to 340 feet, and 1 groundwater sample obtained from the cone penetrometer. The CPT soundings were pushed to refusal (depths ranging from 130.1 to 156.7 feet). Data from two existing borings were also utilized for correlation. Seismic data, located near Site B and obtained during the DWPF characterization, were also reviewed for local geologic structure.

The CPT data were correlated and interpreted for engineering stratigraphy. Boring SDFB-B1 was stratigraphically correlated with local borings and regional type well $\mathrm{P}-27$. The boring and CPT data were then correlated. Soil samples from the boring were analyzed in the laboratory for index properties associated with each engineering layer.

The results of this investigation are:

- Site topography is suitable for potential construction. There are no natural drainage, cut and fill or road and rail profile problems.

- There are no surface hydrology or potential floodplain problems that might affect construction suitability.

- Groundwater was encountered at an elevation (approximately 238 feet, $\mathrm{msl}$ ) which may impact excavation, depending on final facility design. 
- The groundwater sample was analyzed for tritium and volatile organic analytes. Analyses of the groundwater sample indicate that tritium and organic volatiles were below the drinking water standards.

- Soft zones were detected in two of the ten CPT soundings and along the northeastern portion of Site B. Further evaluation of these soft zones may be warranted. Siting and design of new facilities in this area should account for the presence of these soils either by avoiding the placement of critical facilities where these zones are known to exist, or determining the potential settlement and then designing the facility to accommodate the estimated movement.

- No geologic structure was noted at Site B. A review of regional information indicates that there are no known faults in the area that affect the Gordon Aquitard.

- The stratigraphy and average index properties determined for the Salt Disposition Facility - Site B are consistent with those determined for other facilities in S-Area. Geologic conditions are also directly comparable between these areas.

- Based on the preliminary data obtained from this geotechnical investigation, Site $B$ is acceptable for continued construction consideration.

Design and construction of new PC-3 and higher facilities, heavily loaded structures or capital investment projects in the Site B area will require structure specific investigations for foundation design and construction, as well as, proper characterization of soft zone intervals. Foundation specific investigations should consider structure size, geometry, loading, foundation type and depth, performance classification and functional classification. A limited program of field testing to confirm dynamic soil properties may be required to obtain baseline subsurface information such that a site-specific comparison with results of this investigation can be made. A thorough review of the data included in this report is recommended for planning further investigations. 
Site Geotechnical Services

K-TRT-S-00001

Preliminary Siting Characterization

Rev. 0

Salt Disposition Facility - Site B (U)

July 1999

\section{INTRODUCTION}

A siting and reconnaissance investigation has been completed in S-Area at the Savannah River Site (SRS) in South Carolina. This program included an investigation of the subsurface conditions for the area known as "Salt Disposition Facility (SDF), Site B" located northeast of H-Area and within the S-Area (Figure 01). This preliminary geotechnical investigation serves as a baseline characterization program to determine suitability and guide foundation specific geotechnical investigations for design. Site B was selected as one of several potential facility locations following the evaluation of the Site Selection Panel (WSRC-RP-99-00513, Rev. A). The primary focus of the Site B investigation was to gather subsurface information within the potential facility footprint and tie this information with the historical studies completed for the Defense Waste Processing Facility (DWPF) located northwest and adjacent to the Site B area.

Data acquired from the Site $B$ investigation include both field exploration and laboratory data, which are included within this report. Results of this investigation are intended to be used as a baseline for the siting of the Salt Disposition Facility. Further, these data will augment specific foundation design investigations for the proposed SDF facilities to be constructed in this area once the geometry and layout have been finalized. The program consisted of a field exploration program including a Standard Penetration Test (SPT) to 180 feet and a core boring to 340 feet, four Seismic and six Resistivity Piezocone Penetration Test (SCPTU and CPTU) soundings; a laboratory testing program and an evaluation of subsurface conditions. Data from two historical borings and two historical seismic lines were also reviewed as part of the Site B evaluation. Figure 1.0-1 shows the locations of the CPT's and the SPT boring, existing seismic data and the nearby borings.

This preliminary geotechnical program was performed by the SRS Project Engineering and Construction Division (PE\&CD), Site Geotechnical Services (SGS) Department; in conformance with DOE Order 420.1, Procedure Manual E7, (WSRC, 1996a), and SGS Procedure Manual E9 (WSRC, 1996b).

\subsection{Purpose and Objectives}

The purpose of the investigation was to obtain geotechnical information to characterize the subsurface conditions within the Site B footprint, determine suitability, and compare these conditions with the adjacent areas. The specific geotechnical siting considerations are listed below in Table 1.1-1. Specific characterization objectives included:

- define the engineering stratigraphy including the continuity, thickness and relative elevation of stratigraphic units across the study site;

- determine the index properties of each stratigraphic layer; 
Site Geotechnical Services

K-TRT-S-00001

Preliminary Siting Characterization

Rev. 0

Salt Disposition Facility - Site B (U) July 1999

- compare the field results (SPT and CPT measurements) to results obtained in S-Area,

- evaluate the presence, thickness and stratigraphic position of soft zones, if any;

- evaluate the presence, style, orientation, and age of potential faulting within the area, and

- evaluate the subsurface conditions in terms of relative geotechnical and foundation suitability.

Table 1.1-1. Geotechnical Siting Criteria

\begin{tabular}{|l|}
\hline Topography \\
\hline Site topography \\
\hline Natural drainage localized \\
\hline Natural drainage at facility footprint \\
\hline Balanced cut and fill \\
\hline Road and rail profiles \\
\hline Surface Hydrology \\
\hline Proximity to floodplain \\
\hline Local flooding \\
\hline Subsurface Hydrology \\
\hline Ground water depth \\
\hline Ground water contamination \\
\hline Geology (soft zone carbonates) \\
\hline Seismology (proximity to known fault) \\
\hline
\end{tabular}

\subsection{Report Organization}

The text of this report includes six sections. These sections are: Section 1, Introduction; Section 2, Subsurface Exploration; Section 3, Subsurface Conditions; Section 4, Geotechnical and Foundation Assessment, Section 5, Conclusions and Recommendations; and Section 6, References. These sections are followed in succession by tables and figures.

Appendices to this report include: Appendix A, Boring Logs; Appendix B, Laboratory Test Data; and Appendix C, Seismic Piezocone Penetrometer Test Soundings, Appendix D, Resistivity Piezocone Test Soundings, and Appendix E, Water Quality Laboratory Analysis.

\subsection{Quality Assurance}

Quality related activities performed by WSRC/BSRI organizations during the Geotechnical Investigation were controlled in accordance with the WSRC QA Program as delineated in WSRC Procedure Manual 1Q and WSRC 3Q5.. Activities were also controlled via compliance to the applicable administrative and technical 
procedures contained in WSRC Procedure Manual E9, "Site Geotechnical Services."

Cone Penetration Testing (CPT) was conducted in accordance with the Quality Assurance (QA) Plan for WSRC Subcontract AA82276N, with Applied Research Associates, Inc. (ARA) and the ARA Quality Assurance Program for Cone Penetration Testing, Revision 3 (7/30/96). Subcontractor compliance with their implementing procedures and instructions (ARA-Q-101 through 107) also ensured the integrity of the CPT results and interpretations.

Soil testing performed by Law Engineering of Atlanta, Georgia (WSRC Subcontract No. AB80111N) was accomplished through compliance with the Law Engineering QA Program as delineated in the Law Engineering Quality Assurance Manual, Revision 1 (7/25/97), and applicable national/industry test standards (as specified in procurement specification K-SPC-G-00016, Revision 0).

SGS QA provided oversight over all quality-related activities of the geotechnical investigation. SGS QA oversight activities included: the review and approval of all technical and quality procedures and instructions developed specifically for the investigation; monitoring field activities, sample handling, and soil testing laboratory activities; and providing direct QA oversight over seismic piezocone penetration testing activities.

QA/QC activities were also performed by Law Engineering and Applied Research \& Associates personnel as prescribed in their respective QA plans, QA programs, and QA technical procedures. 


\section{SUBSURFACE EXPLORATION}

In May, 1999, a siting and reconnaissance investigation program to support siting of the Salt Disposition facility (SDF) was completed. The information from this program forms the basis for this report.

The exploration program consisted of the following:

- 6 Seismic Piezocone Penetrometer Test (SCPTU) Soundings

- 4 Resistivity Piezocone Penetrometer Tests (CPTU) Soundings

- 1 Standard Penetration Test (SPT) Boring to 180 feet and coring from 180 to 340 feet

- Down-hole Geophysical Logging (Natural Gamma Ray \& Resistivity)

- 1 CPT Groundwater Sample

In addition, the data from two existing borings, $\mathrm{SBH}-14$ and $\mathrm{SBH}-16$, were utilized for correlation. Two existing seismic lines, S-2 and S-7, acquired for the DWPF geotechnical characterization, and located near the SDF Site B footprint, were also reviewed for geologic structure. Figure 1.0-1 shows the locations of the boring, seismic lines and CPT soundings.

The boring and soundings were advanced in an approximate grid pattern, roughly 100 feet by 100 feet, covering an area approximately 200 by 300 feet, the approximate footprint of SDF Site B.

The CPT was used as the primary exploration technique with direct correlation to a new SPT boring. The SPT boring was located centrally to the soundings to measure $\mathrm{N}$-values and retrieve soil samples for laboratory classification testing. Test methods, equipment, and general field procedures, are summarized in the following sections.

\subsection{Field Test Location and Clearance}

The selection of the boring location, CPT soundings, and other field work with Site $B$ was based primarily on the following criteria and factors:

- Existing Data;

- Data coverage;

- Site conditions (topography, wooded areas, etc.);

- Type of data required;

- Under-and-above ground interferences; and 
- Presence of known or suspected soft zones and subsurface geologic structure.

Approval of the selected location for the fieldwork was preceded by a series of work coordination steps as summarized below (the organization responsible for each step is noted in parentheses):

- Selection of general area based upon the factors listed above (SGS);

- Preliminary interference research (Construction Layout);

- Ground penetrating radar survey (E\&I, Site Services)

- Preparation of work package (SGS/ Operations Department);

- Work Process Control (Operations Department); and

- Field surveys (Construction Layout).

This detailed site clearance routine was essential for safe field operations. Any obstacles or restrictions encountered in any step during this process required the relocation of the proposed boring or sounding location, and therefore the reinitiation of the process. A minimum surface clearance of 10 feet from any obstacle or interference was required to assure safe operations of the DWPF.

\subsection{Equipment and Field Test Methods}

Equipment used in the field investigations met applicable ASTM standards, site standards and procedures as listed below:

- WSRC E9 SGS-GT-202 - Drilling Practices;

- WSRC E9 SGS-GT-203 - Sample Preparation, Handling and Storage;

- WSRC E9 SGS-GT-206 - Engineering Soil Descriptions;

- WSRC E9 SGS-GT-207 - Field Log Preparation;

- WSRC E9 SGS-GT-210 - Standard Penetration Test;

- WSRC E9 SGS-GT-211 - Cone Penetration Test Soundings; and

- WSRC 3Q5 Manual - Hydrogeologic Data Collection.

\subsubsection{Exploration Contractor(s) and Equipment}

One drilling contractor was utilized for the SPT boring and one contractor was used for the SCPTU and CPTU soundings. A description of the scope of each contractor and the equipment used is provided below.

Graves Environmental, Inc.

Graves Environmental, Inc., of Jackson, South Carolina performed the drilling and sampling for the SPT boring and coring. The Graves Environmental drillers involved with the drilling and sampling activities were experienced with geotechnical 
Site Geotechnical Services

K-TRT-S-00001

Preliminary Siting Characterization

Rev. 0

Salt Disposition Facility - Site B (U)

July 1999

investigations and have performed the drilling and sampling for numerous investigations on site. The drilling equipment utilized is described below.

Failing 1500

The Failing 1500 drill rig is gasoline engine powered with a 40 -foot mast. The rig has a 23-foot Kelly assembly which allows for a 20 -foot stroke and is capable of mud rotary, augering, and rotary coring techniques. The drill string is controlled by the Kelly arrangement, as well as, by a mechanical winch. This rig was used for all deeper borings requiring mud rotary.

\section{Applied Research Associates (ARA)}

Applied Research Associates (ARA) of Royalton, Vermont the SCPTU and CPTU soundings and data processing activities. The CPT rig used for this investigation is described below.

Mac I

The 22-ton Mac I CPT rig is capable of a 30-ton push when fully ballasted. The push rod and piezocone conformed to ASTM D5778 (ASTM 1995) consistent with WSRC E9 SGS-GT-211 - Cone Penetration Test Soundings. This rig was equipped with a hydraulic skid coupled to the surface beneath the rig for generating a shear wave source. Compressional waves were generated with a hydraulic vertical hammer located on the outside of the rig. The operator controlled all components.

\subsubsection{Standard Penetration Test (SPT)}

Tests were performed in accordance with WSRC E9 SGS-GT-210 using a standard 24-inch long by 2-inch outside diameter (OD), split-spoon sampler with a 2-foot bleeder and check valve located above the sampler, NX drill stem, and a 140-lb safety hammer falling 30 inches. SPT $\mathrm{N}$-values were determined by adding the number of blows required to drive the split-spoon sampler the middle 12 inches of the standard 24-inch drive.

The general test procedure, as noted in sequence, is outlined below:

1. Split spoon is lowered into nominal 4-inch diameter borehole;

2. Depth is checked and any rod settlement noted;

3. Six-inch intervals, totaling 24 inches, are marked on the drill rod above the turntable;

4. Sampler is driven by blows applied using a 30-inch stroke with the rope wrapped twice over the cathead;

5. Sampler retrieved and recovery noted;

6. Sampled interval reamed and drilled out to next sample interval; and 
7. Process repeated.

Prior to each SPT, the Geotechnical Oversight professional verified that the spoon was properly assembled, making sure the bleeder and check valve were clean and the drive shoe was in good condition.

\subsubsection{Undisturbed Sampling}

No undisturbed samples were obtained as part of this effort

\subsubsection{Piezocone Penetration Soundings (CPTU)}

CPTU, including seismic (SCPTU) soundings and resistivity (CPTU), were performed in accordance with ASTM D5778. The CPT was used because of the relatively quick and clean operation and its ability to provide a continuous soil profile for determining stratigraphy and defining the extent of soft and/or loose soil zones. All CPT soundings included either shear wave velocity measurements at 3foot intervals or continuous measurements of resistivity. Target penetration depths were based upon the estimated elevation of the top of the Congaree formation (approximate El. 120-125 feet MSL), a dense sandy layer (see section 3) that is considered incompressible. However, actual depths varied, depending upon ground surface elevations and subsurface conditions.

\subsubsection{Borehole and Penetration Abandonment}

Abandonment of borings and soundings was performed per WSRC Manual 3Q5, Hydrogeologic Data Collection (WSRC, 1992). The standard grout mix consisted of the following:

- One sack Type 1 Portland Cement (94 lb. sack);

- Two pounds of dry sodium bentonite; and

- 6.5 to 7.5 gallons of potable water.

The boring was abandoned immediately upon completion of testing. Grouting was accomplished via the tremie method by lowering a grout pipe to the bottom of the boring and jetting grout until the boring fluid was displaced and grout returned to the surface. The boring was subsequently topped off until the grout column remained static.

Cone penetrometer soundings were also abandoned via the tremie method by pressure grouting through a push rod that was re-pushed down to the bottom of the sounding. A grout tube extending to the bottom of the push rod was used to pump grout into the hole as the push rod was retracted. Holes were also topped off until the column remained static. 


\subsection{Sample Preparation, Handling, Storage, Transportation, and Control}

Samples were prepared and handled in accordance with WSRC E9 SGS-GT-203 Sample Preparation, Handling and Storage.

For the SPT boring, a sample was typically collected from the top and bottom of the sample spoon. If a material change occurred within the sample, additional samples were collected, as appropriate. Samples were placed in 8-ounce glass jars. The tops were closed tightly, wrapped, sealed with electrical tape, and samples were labeled on both the jar and the lid. While onsite, all samples were stored in accordance with WSRC E9 Procedure SGS-GT-203.

All soil samples selected for testing were turned over to Law Engineering for transport to their laboratory in Atlanta. Once in Atlanta, the samples were maintained in a controlled area according to the Law Engineering Quality Assurance Program. 
Site Geotechnical Services

K-TRT-S-00001

Preliminary Siting Characterization

Rev. 0

Salt Disposition Facility - Site B (U)

July 1999

\section{SUBSURFACE CONDITIONS}

Both existing regional geological information and information obtained from this field exploration program have been used to characterize the subsurface conditions in the Site $B$ area. This included establishing the regional geological ties, engineering stratigraphy and soil index properties.

The Site B subsurface data were tied to existing S-Area borings and regional well P27 (reference Figure 3.0-1) located adjacent to the ITP Facility, according to the correlation shown on Figure 3.0-2. The CPT data were tied to the boring data as shown in Figure 3.0-3. Further, the presence of soft sediments defined as zones with measured tip resistances less than 15 tons per square foot (tsf) over two continuous feet or SPT N-values of 5 or less, were evaluated. Groundwater conditions were determined from nearby monitoring well information and CPT data.

Subsurface three-dimensional models (Figures 3.4-3 through 3.4-5) were developed to show the engineering stratigraphy, Tip Stress and Friction Ratio across the Site B area. The models of the CPT Tip Resistance $\left(q_{t}\right)$ and the Friction Ratio (FR) were made to show the detailed stratigraphy underlying the site. These subsurface models were based on information collected during this investigation. Some variation from these conditions can be expected.

\subsection{Regional Geological Evaluation}

The SRS is situated on the upper Atlantic Coastal Plain approximately 30 kilometers southeast of the Fall Line which separates the relatively unconsolidated coastal plain sediments from the crystalline igneous and metamorphic rocks of possibly late Precambrian to late Paleozoic age in the Piedmont Province. Early to middle Mesozoic (Triassic to Jurassic) rocks occur in isolated fault-bounded valleys either exposed within the crystalline belts or buried beneath the coastal plain sediments. The coastal plain sediments were derived from erosion of the crystalline rocks during late Mesozoic (Cretaceous) through Eocene to possibly Miocene time. Younger late Tertiary to Recent sediments form alluvial fill in stream and river valleys and locally are represented by gravel deposits adjacent to present-day streams and by sediments filling upland depressions (sinks and bays). The Cretaceous and younger sediments are not significantly indurated. The total thickness of the sediment package at SRS varies between approximately 700 feet at the northwest boundary and 1200 feet at the southeast boundary.

\subsection{The Atlantic Coastal Plain Stratigraphy Underlying Site B}

The Atlantic Coastal Plain stratigraphic column used in this report is given in Figure 3.2-1. A discussion of the Cretaceous and Tertiary-Paleocene and early Eocene subsurface units underlying the SRS and Site B can be found in Aadland et al, (1995), and in the Generic Safety Analysis Report, G-SAR-G-00001 Rev. 4 (1999). 
The following describes the character of the shallow sediments (Warley Hill Fm. to the surface) underlying Site $B$ and is based on geologic descriptions from borehole SDFB-B1, Fallaw and Price, (1994) and Aadland et al. (1995). A photograph of samples of the subsurface strata (upper 100 feet) is shown on Figure 3.2-2. Detailed field sediment descriptions may be found in Appendix $A$. where the formation, depth of occurrence in boring SDFB-B1 and a general sediment description are given.

Fill Material (elev. $274 \mathrm{ft}$-surface, msl) This udorthent interval consists of backfilled material graded or excavated from local construction activities overlying the naturally deposited "Upland Unit". This material is not shown in Figure 3.2-2.

Upland Unit (elev. 250-274 ft. msl) The "Upland Unit" is an informal stratigraphic term that has been applied to relatively local deposits that outcrop at higher elevations in the coastal plain of southwestern South Carolina. Units in a similar stratigraphic position in Georgia are usually called Altamaha Formation. It consists of dark red, brown, orange, poorly sorted clayey to silty sand locally contains lenses and layers of conglomerate, pebbly sand and clay. Cross bedding and white flecks, which may be very weathered feldspar, are locally common. Figure 3.2-2 shows this mixture of sediment to a depth of approximately $30-32$ feet averaging approximately 24 feet thick. The "Upland Unit" is generally fluvial, and is deposited on a scoured, erosional surface on the Tobacco Road Formation. The age has not been definitively determined, and correlation with similar deposits in the region is not yet clear. The "Upland Unit", Tobacco Road Formation, and Dry Branch Formation may be part of the same cyclic regressive/transgressive depositional system with the "Upland" being the most continental end member and the Dry Branch the most marine.

Tobacco Road Fm. (elev. 214-250 ft. msl) The Upper Eocene Tobacco Road Formation conformably overlies the Dry Branch Formation. It consists of moderately to poorly sorted, red, brown to variegated purple and orange quartz sand, commonly with clay stringers. Pebble layers and muscovite are locally distributed throughout the formation as well. The Tobacco Road Formation is widely exposed in road cuts and outcrops at the SRS, and at the surface. Figure 3.2-2 shows the color and grain size variation to a depth of approximately 75 feet. The Tobacco Road averages approximately 36 feet thick at Site B. The gradational nature and non definitive color change render the lower Tobacco Road - Dry Branch contact difficult to clearly distinguish, especially in core.

Dry Branch Fm. (elev. 173-214 ft. msl) This formation is a clastic deposit of Upper Eocene age disconformably overlying the Clinchfield Formation. It averages approximately 41 feet thick at Site B. The Dry Branch Formation can be divided into the lower Dry Branch which includes the Griffins Landing and Twiggs Clay Members and an upper Dry Branch consisting of the Irwinton Sand Member. The Twiggs Clay 
is locally referred to informally as the "tan clay". The Griffins Landing Member is a distinctive carbonate-bearing facies. The Irwinton Sand Member, a tan, yellow and orange, moderately well sorted quartz sand, locally interlaminated or intercalated with clay, occurs in a facies relationship with the Griffins Landing and Twiggs Clay Members but generally maintains a superior stratigraphic position to these facies.

Tinker-Santee-Clinchfield Fms. (elev. 133-173 ft. msl) These formations are deposited above the Warley Hill and exist as three distinctive members, although not all may be present at Site B. The Tinker is a thin zone of moderately to well sorted, fine to coarse, calcareous quartz sand. A very thin vertically and laterally discontinuous, partially indurated to indurated, shelly limestone may be present. The Santee Limestone, which consists of cream-colored, micritic to shelly, partially indurated to indurated, biomoldic limestone, may also be present. Overlying the Tinker Formation is the Clinchfield Formation, which consists mostly of tan and yellow, fine to coarse, locally calcareous, quartz sands. An indurated, bioclastic and biomoldic, glauconitic limestone facies, commonly containing abundant echinoid fragments is often present. The Tinker-Santee-Clinchfield interval averages approximately 40 feet thick at Site B.

Warley Hill Fm. (elev. 120-133 ft. msl) The Warley Hill Fm. is a glauconite bearing lithic unit immediately overlying the Congaree Formation consisting variably of clay, clayey sand and silty fine - to medium-grained quartz sand. Thickness across Site B varies from 13 to 15 feet. At the base of this packet of sediments there usually occurs a dark-colored, commonly glauconitic sandy mudstone of variable thickness. This lithology is widespread, consists of clays and interbedded clayey sands and is known as the "green clay" horizon that produces a distinctive signature on the gamma geophysical log.

\subsection{Basement Geology Underlying Site B}

Very few borings or wells have penetrated the crystalline rocks beneath the central SRS and S-Area. Those that have include DRB (deep rock boring) 1 through 8 , as well as HPC-1 and $\mathrm{H}-1$. At Site B, the bedrock is anticipated to correspond with the Cumbest et al. (1992) description of "quartz-feldspathic schists, gneisses, amphibolite, hornblende-chlorite schists, metagabbro, and serpentenite, some of which record penetrative mylonitic and cataclastic fabrics, indicating the presence of rocks with felsic, mafic, and ultramafic protoliths". Crystalline rock is buried beneath approximately 960 feet (elev. $-680 \mathrm{ft}$.) of coastal plain sediments. The crystalline rocks are the principal acoustic/seismic velocity interface underlying the SRS.

\subsection{Geological Structure Underlying Site B}

A review of regional data suggests that there are no known tectonic faults that breach the Gordon Confining Zone within a one-half mile radius of Site B. In 
addition, as evidenced by generally flat-lying horizons on the regional correlation panel (Figure 3.0-2), the seismic data adjacent to Site B (Figures 3.4-1 and 3.4-2), the CPT three dimensional engineering strata (Figures 3.4-3) and the CPT crosssection (Figure 3.4-4) there is no apparent offset that would suggest geologic structure or faulting within the Site B footprint. The three-dimensional models (Figures 3.4-5 and 3.4-6) demonstrate no consistent offsets in lateral variation, for sediment character or type that might suggest geologic structure that cannot be explained by variation due to geologic depositional, diagenetic or erosional processes.

\subsection{Engineering Stratigraphy}

The subsurface engineering stratigraphy was determined from the SPT boring, CPT measurements including tip resistance, sleeve resistance, friction ratio, and pore pressure signatures, shear wave velocity, as well as correlation with adjacent soil boring data. The layering system is based on observed changes in the CPT measurements that are correlative between soundings as well as boring information. The layer nomenclature follows an alphanumeric system with layer numbers increasing from top to bottom. Subdivided layers are identified with a letter designation (e.g., 3A). The green clay, which is an informal stratigraphic interval at the SRS, is considered the basal unit for the engineering stratigraphy and is included in the lower most engineering layer 5 . This geologic unit is locally continuous and provides a reliable marker bed. The Green Clay overlays the Congaree Formation which is predominantly a dense, coarse-grained to silty sand.

The following sections describe the physical attributes used to delineate each layer of the 5 engineering stratigraphic layers. Average engineering soil layer top elevations as determined for the CPT soundings are provided in Table 3.5-1. Average soil index properties, SPT values, CPT measurements and shear wave velocity measurements are provided in Table 3.5-2. These parameters were developed as part of this investigation. These results were then compared with results from the Defense Waste Processing Facility (DWPF) Balance of Plant Geotechnical Report, D'Appolonia (1982a, Section 3.6).

\subsubsection{Layers 1 and $1 \mathrm{~A}$}

Layers 1 and $1 \mathrm{~A}$ represent the uppermost layers characterized in the study area. The combined thickness of layers 1 and $1 \mathrm{~A}$ averages about 36 feet thick with layer $1 \mathrm{~A}$ averaging about 5 feet thick. Layer 1 is characterized by moderate CPT tip resistances (avg. $100 \mathrm{tsf}$ ), relatively high friction ratios (avg. 3 percent), a relatively high $\mathrm{N}$-value (42 blows/foot) and shear wave velocity (1199 fps) while layer $1 \mathrm{~A}$ is less dense with lower tip resistances (avg. $32 \mathrm{tsf}$ ), high pore pressure measurements (avg. 1.4 tsf), low $\mathrm{N}$-values (13) and lower shear wave velocities (1117 fps). Layer $1 \mathrm{~A}$ is mappable across the entire study area with the exception of 
CPT sounding 7 and located at the base of layer 1 . Layer $1 \mathrm{~A}$ was subdivided from layer 1 due to the nearly continuous extent and relatively shallow position of the layer. From available boring data, the soils of Layer 1 and $1 \mathrm{~A}$ consist of red, purple and brown poorly sorted sands ranging from fine to gravel size with the dominant soil classification being clayey to silty sands (SC to SM). Layer 1A probably contains a higher fines content than layer 1 (i.e., silt and clay sized material).

\subsubsection{Layer 2}

Layer 2 averages about 39 feet thick. Layer 2 is distinguished from the overlying layer 1 and $1 A$ by increased tip resistances (avg. 162 tsf), lower friction ratio values (avg. 1 percent), moderate $\mathrm{N}$-values 25 blows/foot) and shear wave velocities (1122 fps). Layer 2 is predominantly sands and clayey sands (SP-SM to SP-SC) as determined by laboratory classification tests.

\subsubsection{Layers 3 and $3 A$}

The combined thickness of layers 3 and $3 A$ is about 21 feet over the study area. Layer 3 and $3 A$ represent stratigraphically equivalent layers however layer $3 A$ is used to distinguish where the interval has become denser noted from increased tip resistances. Layer 3 is distinguished by relatively lower tip resistances (avg. 31 tsf) than layer $3 \mathrm{~A}$ (avg. $89 \mathrm{tsf}$ ), and higher Friction ratio (1.7\% versus $0.8 \%)$. Shear wave velocities are correspondingly higher in layer $3 A$ than layer 3 (1079 fps versus $966 \mathrm{fps}$ ). Based on laboratory test data, the dominant unified soil classifications for layer $3 A$ is $S C$ and $S M$ with minor layers of $C L$ material occurring as laminations. Layer 3 probably contains slightly more fines (i.e. more clayey) than layer $3 \mathrm{~A}$.

\subsubsection{Layers 4 and $4 A$}

The combined thickness of layer 4 and $4 A$ is about 20 feet thick. This layer is distinguished from the overlying layer 3 and $3 A$ by increased tip resistances. As with layer 3 and $3 A$, layer 4 and $4 A$ are stratigraphically equivalent layers with layer $4 \mathrm{~A}$ being used to distinguish were average tip resistances are lower than layer 4. Layer 4 has notably higher tip resistances (avg. 184 tsf) than layer 4A tip resistances (avg. $108 \mathrm{tsf}$ ). The dominant unified soil classification for layer 4 and 4A is SP-SM where layer 4A may contain slightly higher fines content than layer 4 .

\subsubsection{Layer 5}

Layer 5 is about 41 feet thick and is characterized by alternating layers of low and high CPT tip resistances (max. 813 tsf, min. 11 tsf, avg. 88 tsf), friction ratios (max. 8.4 percent, min. 0.2 percent, avg. 1.6 percent), tip resistances (27 blows/foot) and an average shear wave velocity of $1142 \mathrm{fps}$. Characteristically, CPT soundings in this stratigraphic interval layer show a pronounced sawtooth trace with large variations over relatively small vertical intervals. The depositional history of these 
sediments is complex and highly variable in both its lithology and material properties. Soil types range from sands to silty sands (SP-SM to SM) with varying amounts of carbonate material. Within the study area, relatively little to no carbonate material was encountered with the SPT boring SDFB B1.

The lower portion of layer 5 contains the "green clay" (GC) which is an informal stratigraphic name at SRS for stiff, green to gray clays, silts, and clayey sands that are commonly found at the base of the Santee/Tinker Formation and as part of the Warley Hill Fm. In general, these soils classify as SM to ML with varying amounts of clay. This layer is locally continuous within the study area and has been used to define the lower boundary of the shallow stratigraphy.

\subsection{Soil Characteristics}

A summary of all CPT engineering layer picks for Site B is provided in Table 3.5-1. Average soil index properties and results from the SPT and CPT measurements are provided in Table 3.5-2. Layer continuity across the area is shown on the threedimensional model in Figure 3.4-3 and on the cross-section on Figure 3.4-4. Figures 3.6-1 through 3.6-3 show mean and standard deviations of shear wave velocity $\left(V_{s}\right)$, CPT tip resistance $\left(q_{t}\right)$ and CPT friction ratio $\left(R_{f}\right)$ with the generalized average engineering stratigraphy. SPT $\mathrm{N}$-values are plotted on Figure 3.6-4 showing the range of values versus elevation, as well as, the generalized engineering stratigraphy. Note on Figures 3.6-1, 3.6-2 and 3.6-4 that average values determined for DWPF from Defense Waste Processing Facility, Balance of Plant Geotechnical Report, D'Appolonia (1982a) are included for comparison. For the most part, the results show that the conditions at Site $B$ are consistent with the conditions at DWPF. Laboratory test results are included in Appendix D.

\subsection{Soft Zone Characteristics}

Weight of rod and occasional rod drops have been described in numerous drilling reports for monitoring wells and geotechnical borings located in the central part of the SRS. Early subsurface investigations performed by the United States Army Corps of Engineers (COE) frequently described these zones as soft zones, or even voids, and numerous subsequent subsurface investigations have described these same conditions at the SRS. These soft zones typically occur in the carbonatebearing sediments of the Santee Limestone, Utley Limestone, and the Griffins Landing Member of the lower Dry Branch Formation. The prevailing assumption about the origin of these soft zones is dissolutioning of carbonate-rich, clastic sediments, resulting in vugular porosity (open pore space). When drilling these zones, the drill rod meets little shear resistance and drops (COE, 1951). However, much of the time, recovery of soil in the sampler precludes the zone from being characterized as a void. 
Soft zones are defined by SPT-N values $\leq 5$ or CPT tip resistance $\leq 15$ tsf over a continuous thickness of two feet or greater. These zones are generally restricted to the lower Dry Branch Formation and the Santee/Tinker Formation. However, soft zones may be found in other horizons at the SRS.

Soft zones were detected in two of the ten CPT soundings (SDFBC1 and SDFBC6). In CPT sounding SDFBC1, two soft zone intervals were noted. The first between El. 197 feet $\mathrm{msl}$ to El. 195 feet $\mathrm{msl}$; and the second between El. 188 feet $\mathrm{ml}$ to El. 186 feet msI. In CPT sounding SDFBC6, three soft zone intervals were noted. The first between El. 202 feet msl to El. 193 feet MSL; the second between El. 188 feet msl to El. 186 feet msl; and the third between El. 166 feet msl to El. 158 feet msl. With the exception of the lowermost (third) interval in sounding SDFBC6, these intervals correspond to Layer 3. The lower zone in sounding SDFBC6 corresponds to the uppermost portion of layer 5 . It is noted that the pore pressure measurements and friction ratio values through all of these intervals are relatively high suggesting that these intervals contain fine grained soils. The two soundings are both located on the northern edge of Site $B$. The soft zones encountered at elevations of . approximately 193 to 202 feet msl are within the "Tan Clay". Figure 3.7-1 is a kriged three-dimensional model of the distribution of soft zones underlying Site B.

\subsection{Groundwater Conditions}

Groundwater data were derived from the adjacent water-table monitoring well SBG4, the CPT data, and from WSRC-TR-98-00045, The Regional Water Table of the Savannah River Site and Related Coverages. Monitoring well SBG-4 is the nearest to the Site B footprint. As shown on Figure 3.8-1, the water table elevation from August, 1990 to February, 1995 ranges from approximately El. 238.1 feet MSL to about El. $241.9 \mathrm{msl}$. The mean water-table elevation is 240 feet msl. The watertable as indicated by the pore pressure curves from the CPTs suggests that the current water table elevation is 238 feet msl corresponding to the lower water level. The dominant water table gradient within Site B is oriented to the northeast and is largely controlled by tributaries to McQueen Branch immediately eastward of the SArea. Local water-table contours are shown on Figure 3.0-1. The high water table, (241.9 feet $\mathrm{msl}$ ) and the water table at the time of this investigation, (238 feet $\mathrm{msl}$ ) are shown on Figure 3.4-3.

\subsubsection{Water Quality}

Well SBG-4, adjacent to Site B, has historical levels of tritium and trichloroethene (TCE) above the Drinking Water Standards (DWS). In order to assess the water quality underlying Site B, a water sample was taken adjacent to boring SDFB-B1 and analyzed for tritium and volatile organic analytes (VOA's). This sample was obtained from a depth interval of $40-42$ feet using CPT methodology. The water table depth at the time of the sample was approximately 38 feet. The results of these analyses are: 


$\begin{array}{ll}\text { Tritium } 4.06+/-0.817 \mathrm{pCi} / \mathrm{ml}(\mathrm{DWS}=20 \mathrm{pCi} / \mathrm{ml}) \\ \text { Trichloroethene (TCE) } & <1 \mathrm{ppb}(\mathrm{DWS}=5 \mathrm{ppb}) \\ \text { Tetrachloroethene (PCE) } & <1 \mathrm{ppb}(\mathrm{DWS}=5 \mathrm{ppb}) \\ \text { Benzene } & <1 \mathrm{ppb}(\mathrm{DWS}=5 \mathrm{ppb}) \\ \text { Carbon Tetrachloride (CCl4) } & <1 \mathrm{ppb}(\mathrm{DWS}=5 \mathrm{ppb}) \\ \text { Trichloroflouromethane(Freon11) } & <1 \mathrm{ppb}(\mathrm{DWS}=5 \mathrm{ppb})\end{array}$

The results of these analyses indicate that VOA's and tritium are well below the DWS in the groundwater underlying Site $B$.

\subsection{Topography and Surface Hydrology}

Site $B$ is located within an engineered area associated with the DWPF facility. The area is flat-lying, backfilled and drained. There are no topographic or drainage problems. The area is away from immediate roads and rail lines and no cut and fill problems are anticipated.

Site B exists well above the 100 year floodplain of the tributaries to McQueen Branch, which is located eastward from the site. The site is located on a topographic high and away from drainages or streams. Local flooding is not a problem. 


\section{GEOTECHNICAL AND FOUNDATION ASSESSMENT}

The conditions encountered during this program are not unlike conditions found elsewhere at the SRS. In fact, they are very similar in terms of:

- Geology and soil classification;

- SPT N-values;

- CPT resistances; and

- Shear wave velocity.

Figures 3.6-1 through 3.6-4 show the range of SPT N-values, the mean and range of CPT corrected tip resistance $\left(q_{t}\right)$, CPT friction ratio $\left(R_{f}\right)$ and shear wave velocity $\left(V_{s}\right)$ from this investigation. Based on these results, the soils encountered can support structure and foundation loads currently constructed at the SRS with no adverse consequences. These data also confirm and correlate with the engineering layer picks for Site B. Typical foundation loading for existing critical facilities at the SRS is in the range of 4 to 7 kips per square foot (ksf). Higher loads could be supported depending on the layout, geometry and foundation depths of the proposed facilities and the results of a structure specific geotechnical investigation program, which is required for the proposed SDF mission facilities.

The water table within Site B is approximately 38 to 42 feet below the ground surface, however, perched water should be expected. Local clay layers may be continuous and should be considered for any deep excavations and/or dewatering. 
Site Geotechnical Services

K-TRT-S-00001

Preliminary Siting Characterization

Rev. 0

Salt Disposition Facility - Site B (U)

July 1999

\section{CONCLUSIONS AND RECOMMENDATIONS}

The stratigraphy and average engineering properties determined for the Salt Disposition Facility-Site $B$ are consistent with those determined for other facilities in S-Area. Geologic conditions are also directly comparable.

The results of this investigation are:

- Site topography is suitable for potential construction. There are no natural drainage, cut and fill or road and rail profile problems.

- There are no surface hydrology or potential floodplain problems that might affect construction suitability.

- Groundwater may occur at an elevation (approximately 238 feet, msl ranging up to 242 feet, $\mathrm{msl}$ ) that will impact excavation, depending on final facility design.

- The groundwater sample was analyzed for tritium and volatile organic analytes. Analyses of the groundwater sample indicate that tritium and organic volatiles were below the Drinking Water Standards.

- Soft zones were detected in two of the ten CPT soundings and along the northeastern portion of Site B. Further evaluation of these soft zones may be warranted. Soft zone intervals detected at Site B are consistent with soft zone sediments encountered at the ITP area. Siting and design of new facilities in this area should account for the presence of these soils either by avoiding the placement of critical facilities where these zones are known to exist, or determining the potential settlement and then designing the facility to accommodate the estimated movement. A thorough review of the data included in this report is recommended for planning further investigations.

- No geologic structure was noted at Site B. A review of regional information indicates that there are no known faults in the area that affect the Gordon Aquitard.

- The stratigraphy and average engineering properties determined for the Salt Disposition Facility- Site B are consistent with those determined for other facilities in the $\mathrm{H}$ - and S-Areas. Geologic conditions are also directly comparable between these areas.

- Based on the preliminary data obtained during this investigation, Site B is acceptable for continued construction consideration. 
Design and construction of new PC-3 and higher facilities, heavily loaded structures or capital investment projects in the Site B area will require structure specific investigations for foundation design and construction, as well as, proper characterization of soft zone intervals. Foundation specific investigations should consider structure size, geometry, foundation type and depth, performance classification and functional classification.

Heave monitoring for excavations greater than ten feet deep and settlement monitoring is required for all major and/or critical new facilities throughout the construction phase until final turn-over or when operations commence. After operations commence, settlement monitoring is required on an established interval. Settlement results should be compiled and reviewed by competent geotechnical and structural engineers.

New critical facilities should consider seismic instrumentation in the structure design and facility operation. An SRS Engineering Standard for seismic instrumentation is currently under development. This standard will provide specifications for seismic instrumentation installation and performance. 


\section{REFERENCES}

Aadland, R. K., Gellici, J. A., and Thayer, P. A. (1995), "Hydrogeologic Framework of West-Central South Carolina," S. C. Department of Natural Resources, Water Resources Division, Report 5.

Annual Book of ASTM Standards (1996), American Society for Testing and Materials.

D'Appolonia, (1982a), "Balance of Plant Geotechnical Report, Defense Waste Processing Facility", S-DWP-46.

D'Appolonia, (1982b), "Preliminary Safety Analysis, Defense waste Processing Facility, Volume 4 of 4", S-DWP-45.

Fallaw, W.C., and V. Price, 1995. Stratigraphy of the Savannah River Site and Vicinity, Southeastern Geology. Vol. 35, No. 1, p. 21-58.

WSRC (1992), "Procedure Manual 3Q5, Hydrogeologic Data Collection"

WSRC (1995) "In-Tank Precipitation (ITP) and H-Tank Farm (HTF) Geotechnical Report," WSRC-TR-95-0057, Rev. 0, September.

WSRC (1996a), "Procedure Manual E7, Conduct of Engineering and Technical Support."

WSRC (1996b), "Procedure Manual E9, Site Geotechnical Services."

WSRC (1996c), "F-Area Geotechnical Characterization Report", WSRC-TR-960069, Rev. 0, September 1996.

WSRC (1998a), "APSF Confirmatory Drilling Program Results", PECD-SGS-980115, June, 1998.

WSRC (1998b),"The Regional Water Table of the Savannah River Site and Related Coverages." WSRC-TR-98-00045.

WSRC (1999), "Generic Safety Analysis Report" G-SAR-G-00001, Rev. 4. 
Table 3.5-1. Engineering Layer Horizon Picks (elevation above mean sea level).

$\begin{array}{ccccccccc}\text { CPT ID } & 1 & 1 \mathrm{~A} & 2 & 3 & 3 \mathrm{~A} & 4 & 4 \mathrm{~A} & 5 \\ & & & & & & & & \\ \text { SDFBC1 } & 280 & 248 & 240 & 202 & \text { NP } & \text { NP } & 182 & 161 \\ \text { SDFBC2 } & 277 & 244 & 239 & \text { NP } & 197 & 180 & \text { NP } & 160 \\ \text { SDFBC3 } & 276 & 246 & 241 & 201 & \text { NP } & 184 & \text { NP } & 163 \\ \text { SDFBC4 } & 278 & 247 & 240 & 201 & \text { NP } & 184 & \text { NP } & 164 \\ \text { SDFBC5 } & 276 & 244 & 240 & \text { NP } & 200 & 180 & \text { NP } & 160 \\ \text { SDFBC6 } & 277 & 246 & 244 & 206 & \text { NP } & \text { NP } & 187 & 167 \\ \text { SDFBC7 } & 274 & \text { NP } & 240 & 200 & \text { NP } & 181 & \text { NP } & 160 \\ \text { SDFBC10 } & 277 & 246 & 240 & \text { NP } & 201 & 180 & \text { NP } & 158 \\ \text { SDFBC14 } & 279 & 248 & 241 & 200 & \text { NP } & 184 & \text { NP } & 163 \\ \text { SDFBC15 } & 275 & 249 & 245 & 201 & \text { NP } & 182 & \text { NP } & 159\end{array}$




\section{Table 3.5-2 Average Soil Parameters}

\begin{tabular}{|c|c|}
\hline AVERAGE PROPERTIES & $3 A \quad 4 \quad 4 A$ \\
\hline $\begin{array}{l}\text { SPT N-Value } \\
\text { (blows/foot) }\end{array}$ & W 42 W \\
\hline $\mathrm{q} / \mathrm{N}$ & Wh4 \\
\hline $\begin{array}{l}\text { Shear Wave Velocity }\left(V_{s}\right) \\
(\mathrm{ft} / \mathrm{sec})\end{array}$ & 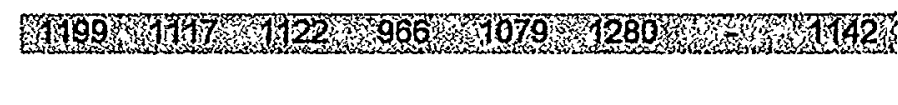 \\
\hline $\begin{array}{l}\text { Corrected Tip Resistance } \\
\text { (qt) } \\
\text { (tons/foot }{ }^{2} \text { ) }\end{array}$ & 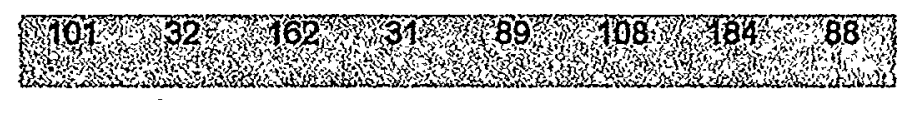 \\
\hline $\begin{array}{l}\text { Friction Ratio }\left(R_{f}\right) \\
(\%)\end{array}$ & 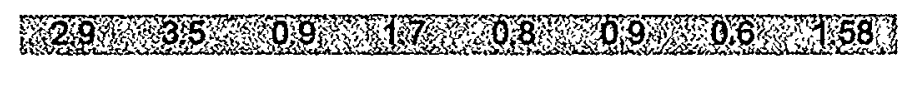 \\
\hline $\begin{array}{l}\text { Percent Fines } \\
(\%)\end{array}$ & n20 \\
\hline $\begin{array}{l}\text { Plasticity Index } \\
\text { (\%) }\end{array}$ & r \\
\hline $\begin{array}{l}\text { Liquid Limit } \\
(\%)\end{array}$ & 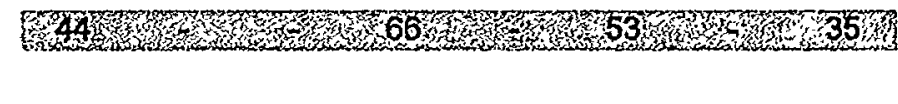 \\
\hline Water Content & 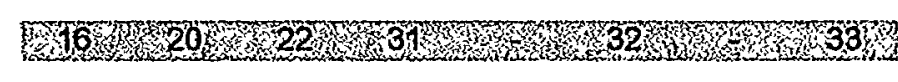 \\
\hline
\end{tabular}

(\%)

\section{Notes}

1. Data for the SDF Investigation includes CPTs $1-7,10,14,15$ and Boring SDFB-B1.

2. Layers $3 A$ and $4 A$ were not correlated to boring SDFB-B1 and values were not calculated. 
Site Geotechnical Services

K-TRT-S-00001

Preliminary Siting Characterization

Rev. 0

Salt Disposition Facility - Site B (U) July 1999

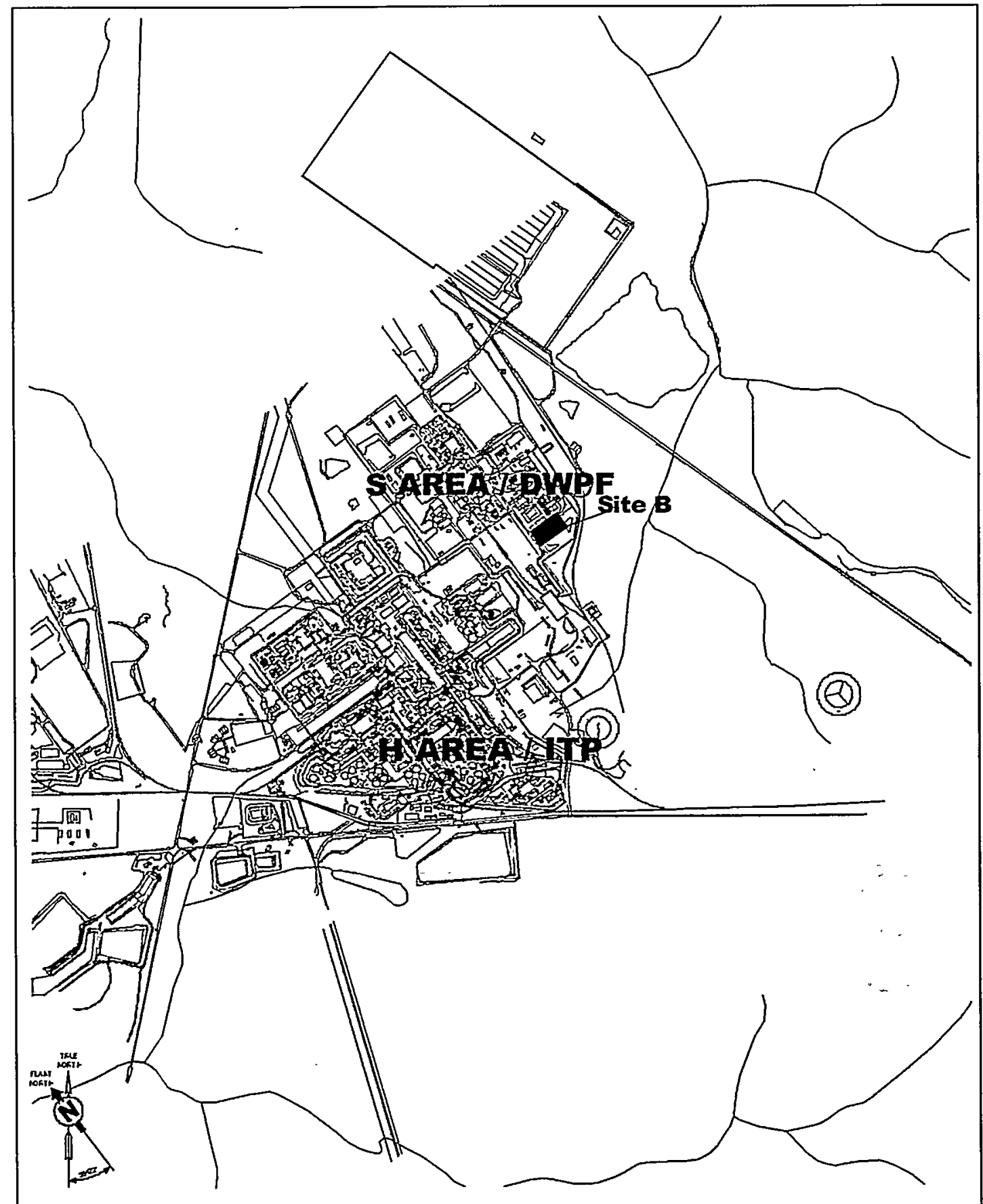

Figure 0-1. Location of Site B relative to H-Area and S-Area. 


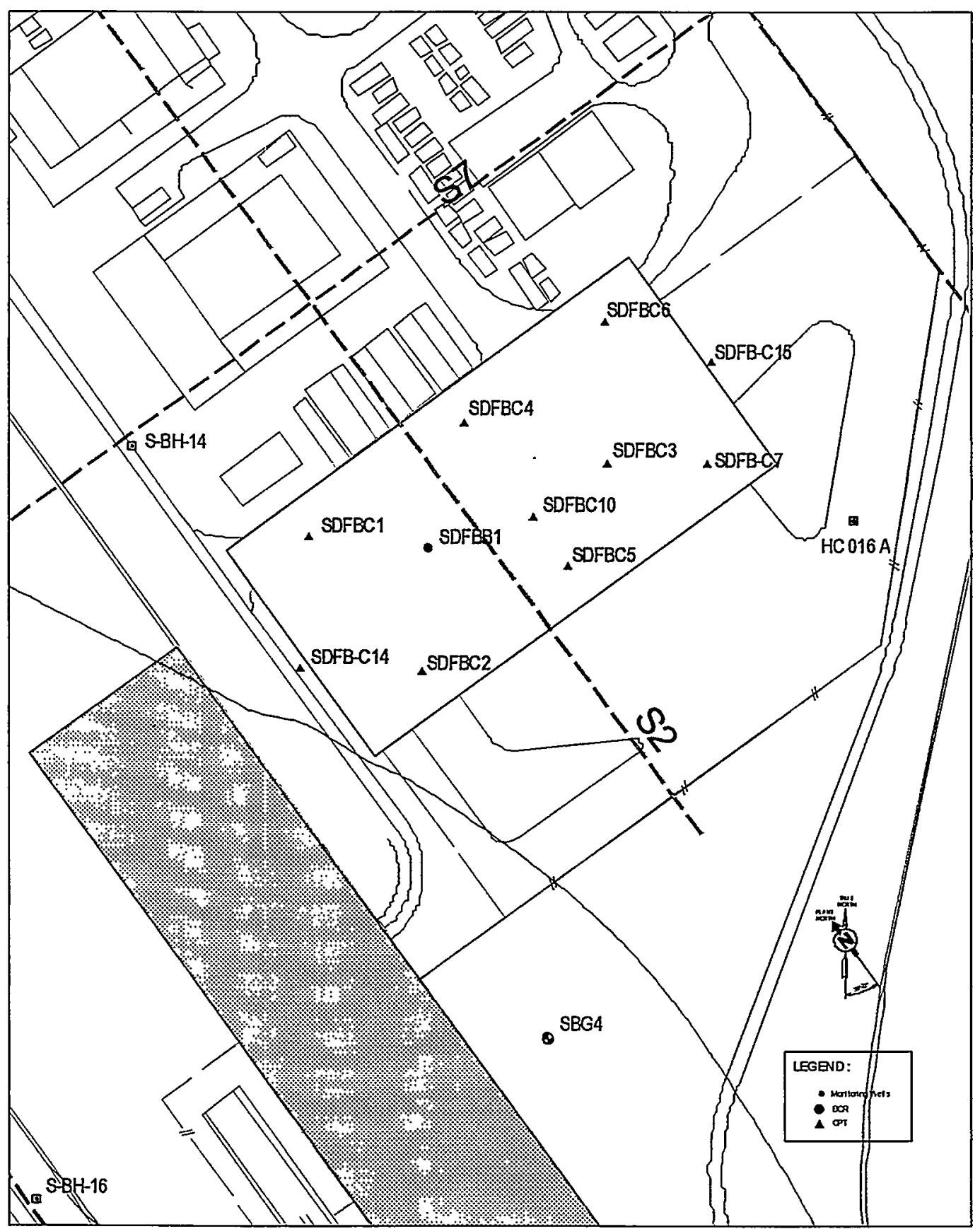

Figure 1.0-1. Location of boring SDFB-B1 and the CPT's within the Site B footprint. Line A $A^{\prime}$ is the engineering cross-section (Figure 3.4-4 HC-16A is an abandoned piezometer cluster. The shaded northwest-southeast trending rectangle is the boundary of the S-Area Sand Blast Area, a potential RCRA/CERCLA waste unit. 


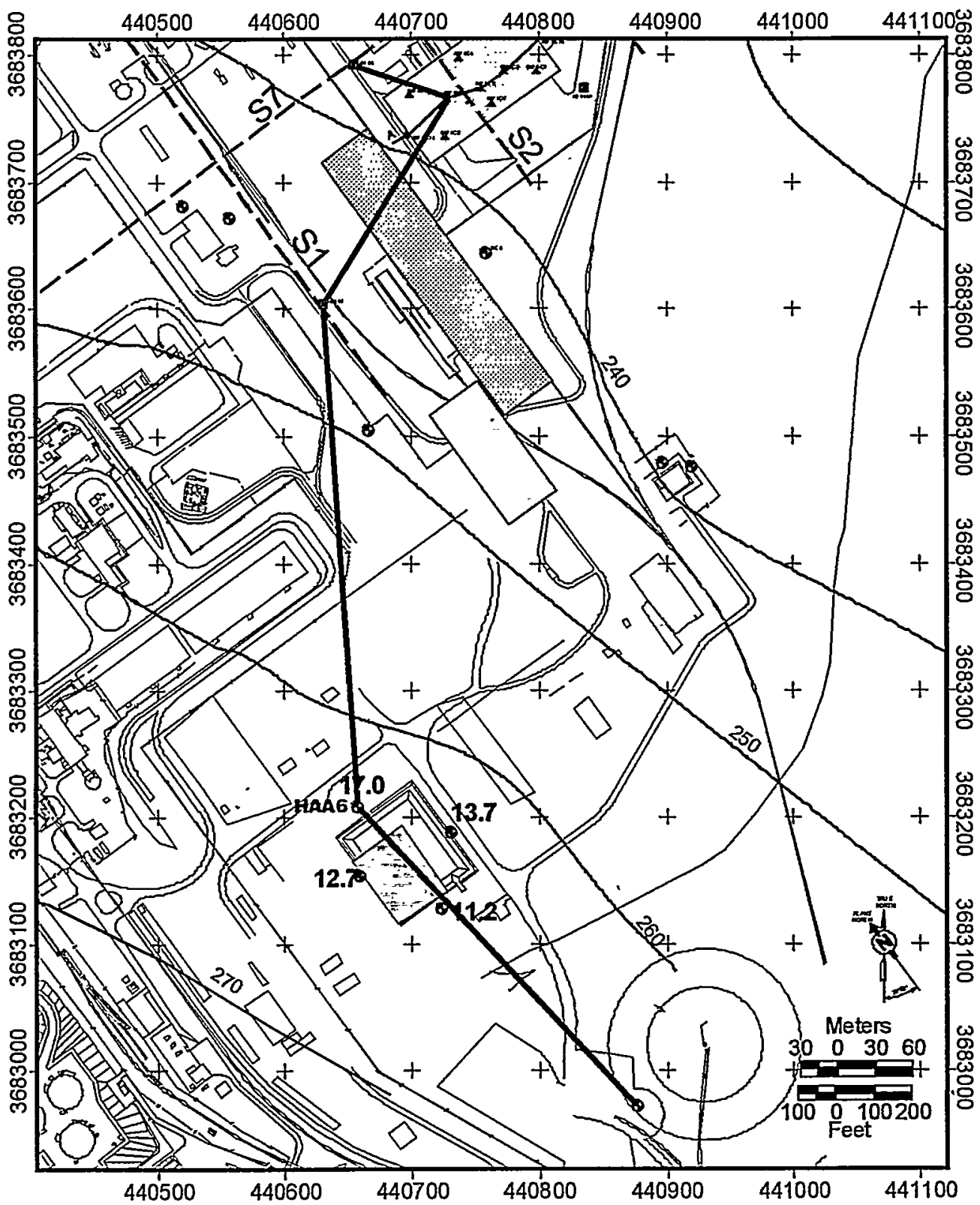

Figure 3.0-1. Correlation tie line from SDFB-B1 to regional well P-27. Blue contour lines are the water table elevations. 
Site Geotechnical Services

Preliminary Siting Characterization

Salt Disposition Facility - Site B (U)

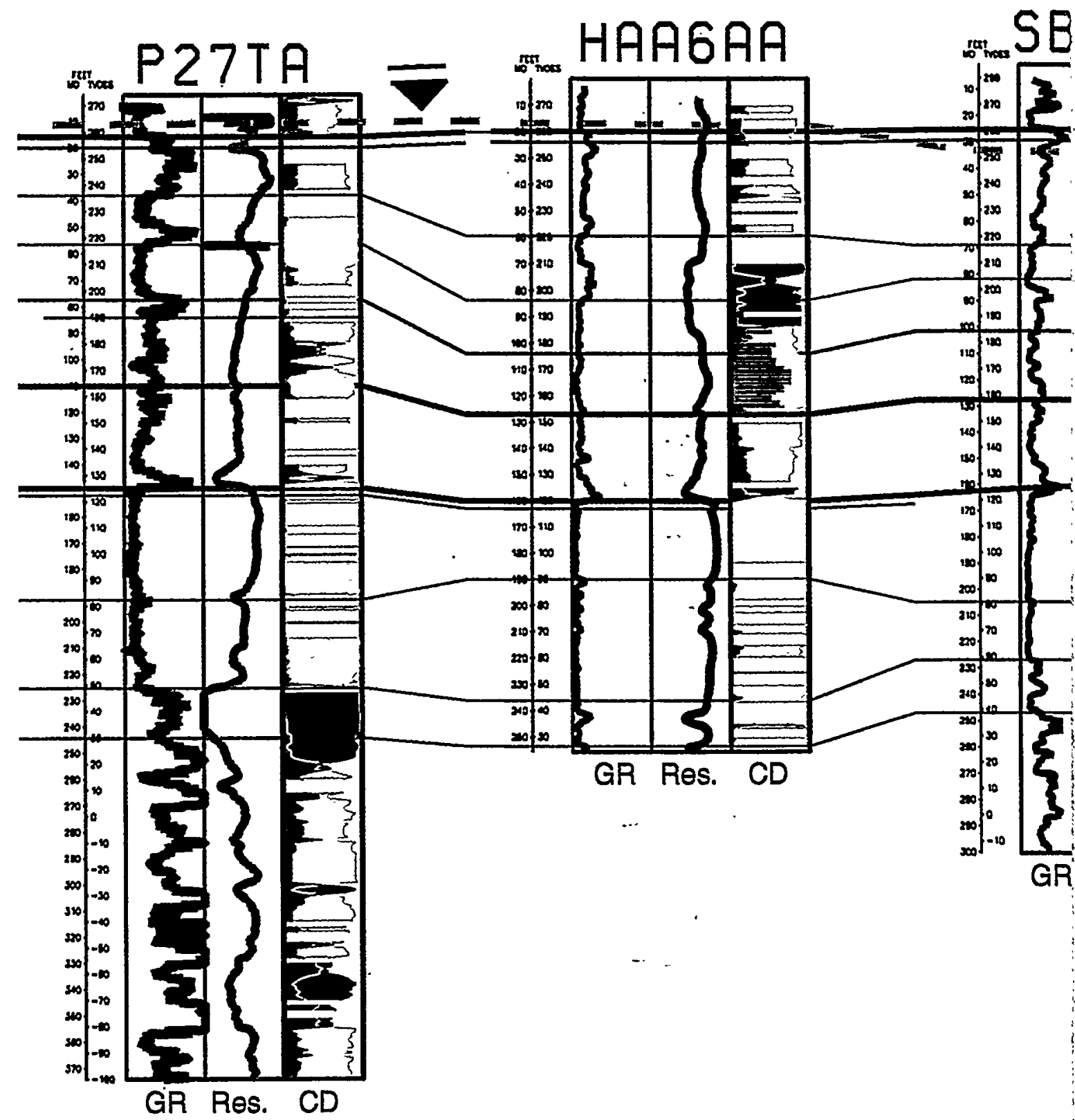

V.E. $=1 x$

$M D=$ measured depth from surface

TVDSS = true vertical depth, subsea

$\mathrm{CD}=$ core data, yellow is relative percent sand, green is percent clay, red percent gravel and

blue percent carbonate

GR = gamma ray, Res. = Resistivity

scale values for $G R$ and $R e s$. vary 
K-TRT-S-00001, Rev. 0

July 1999

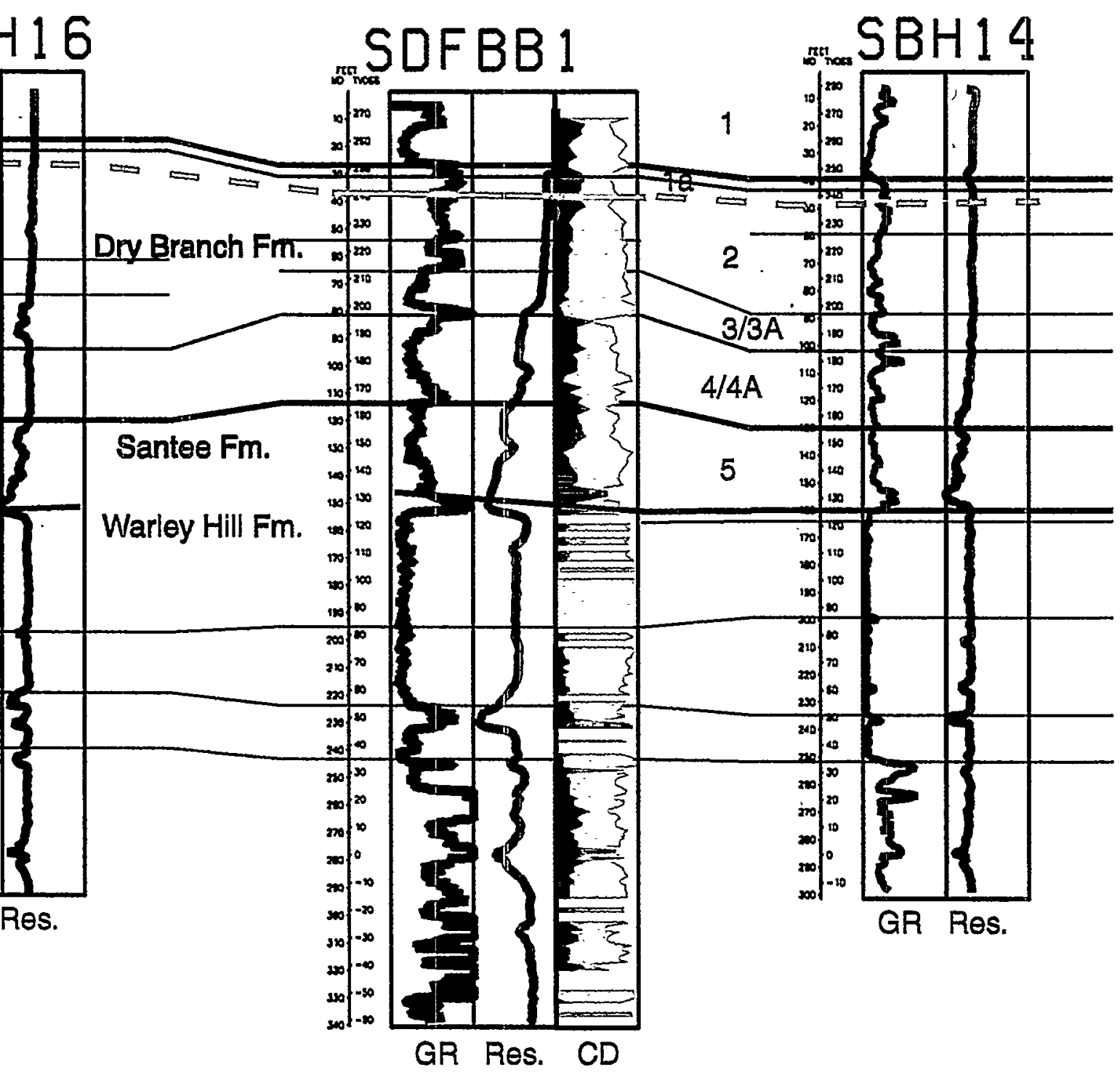

Figure 3.0-2. Correlation panel from regional well P-27 to SDFB-B1. Darker lines are formation markers. Lighter lines are correlation markers on similar sediment packages. The numbered horizons approximately correspond with the engineering layers. The solid blue line is the water table level at the time of the investigation, the dashed line the inferred water table level. 


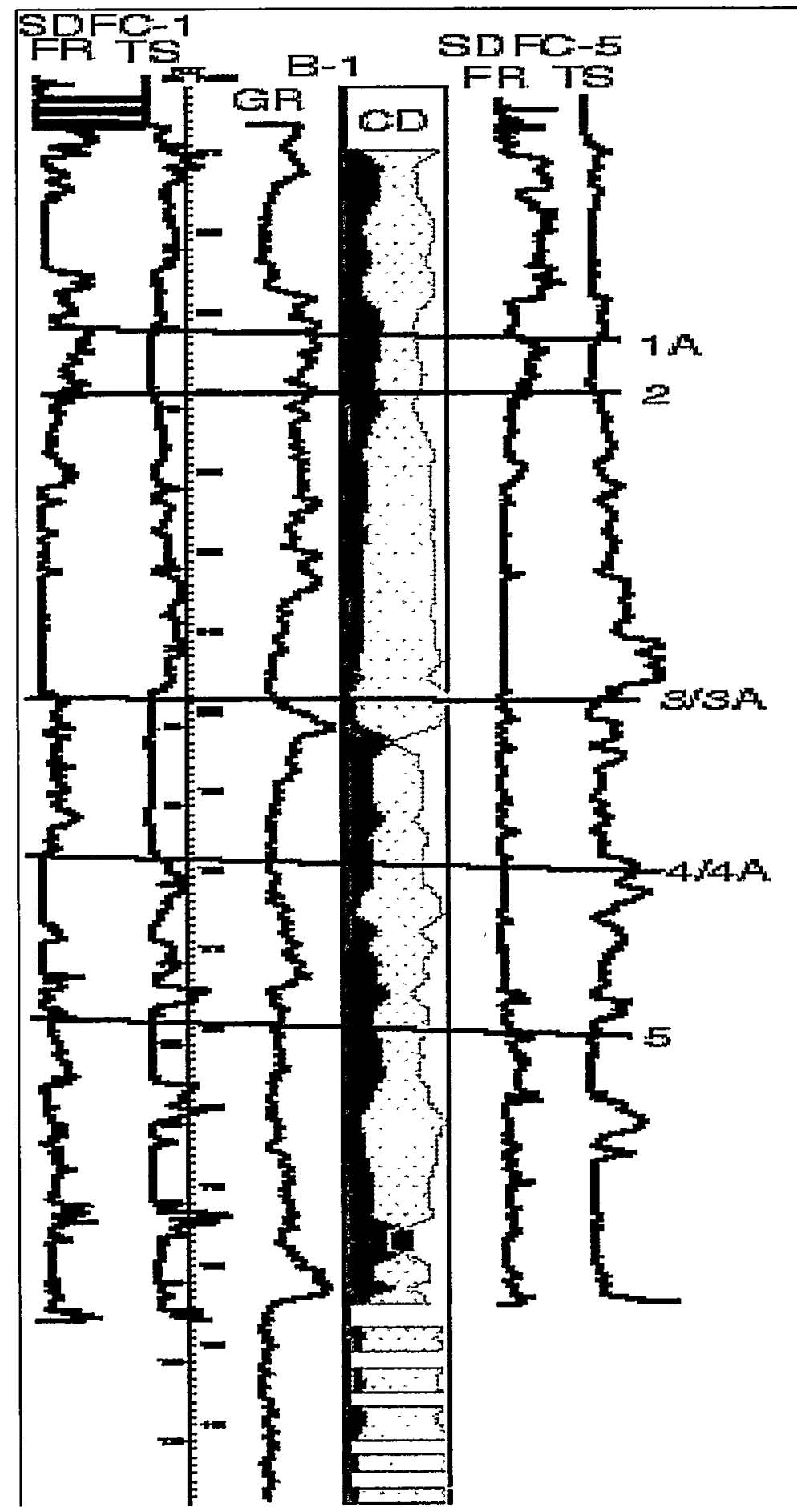

Figure 3.0-3. Correlation between engineering picks from CPT C-1 and C-5 and boring SDFBB1 (reference Figure 1.0-1). The tops of the engineering layers are shown. "FR" is Friction Ratio, "TS" is Tip Stress, "GR" is natural gamma ray and "CD" is core data shown as relative percentage of sand (yellow), clay (green), gravel (red) and carbonate (blue). 


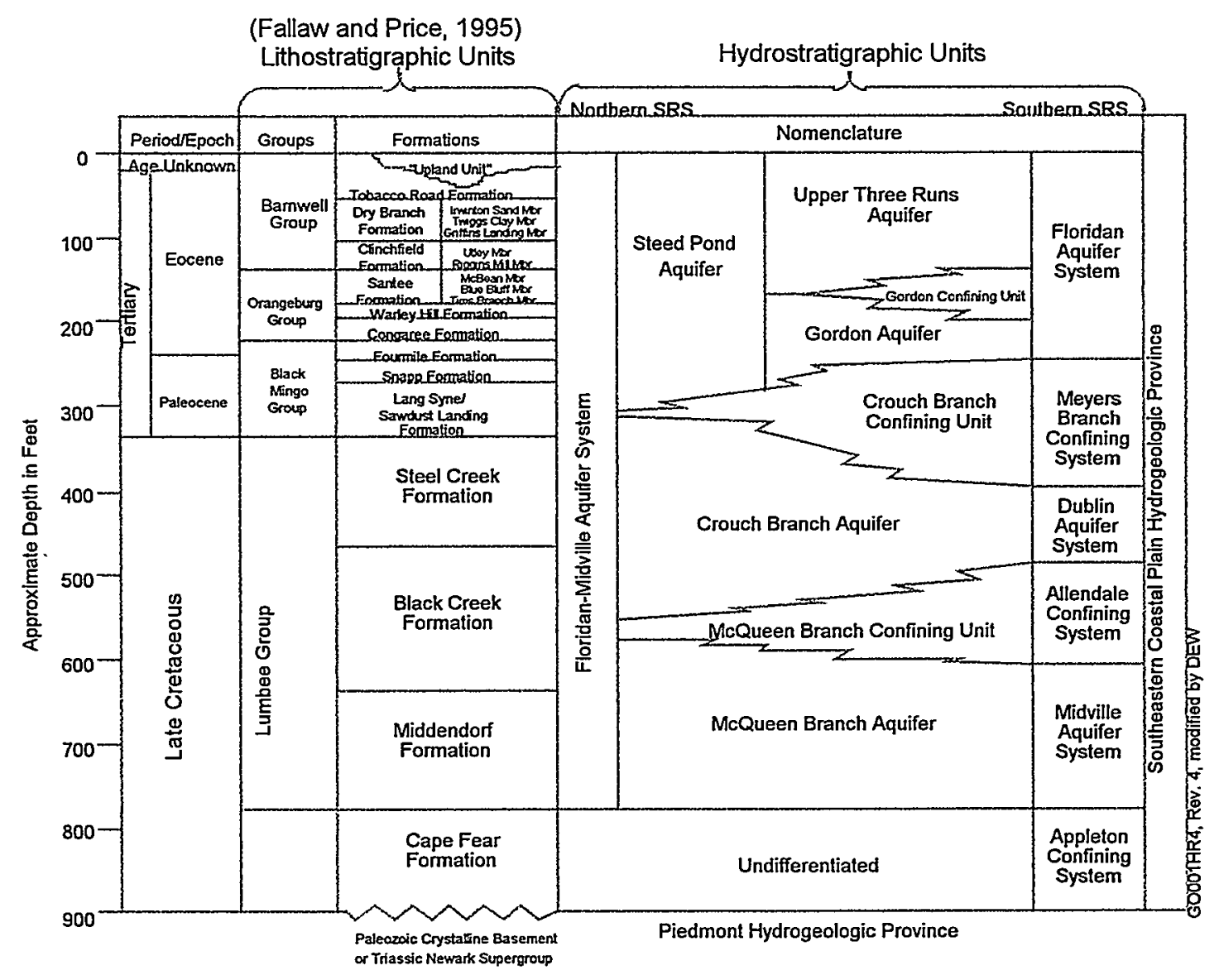

Figure 3.2-1. Generalized Coastal Plain stratigraphy underlying Site B. Figure is from Aadland et al., (1995). 


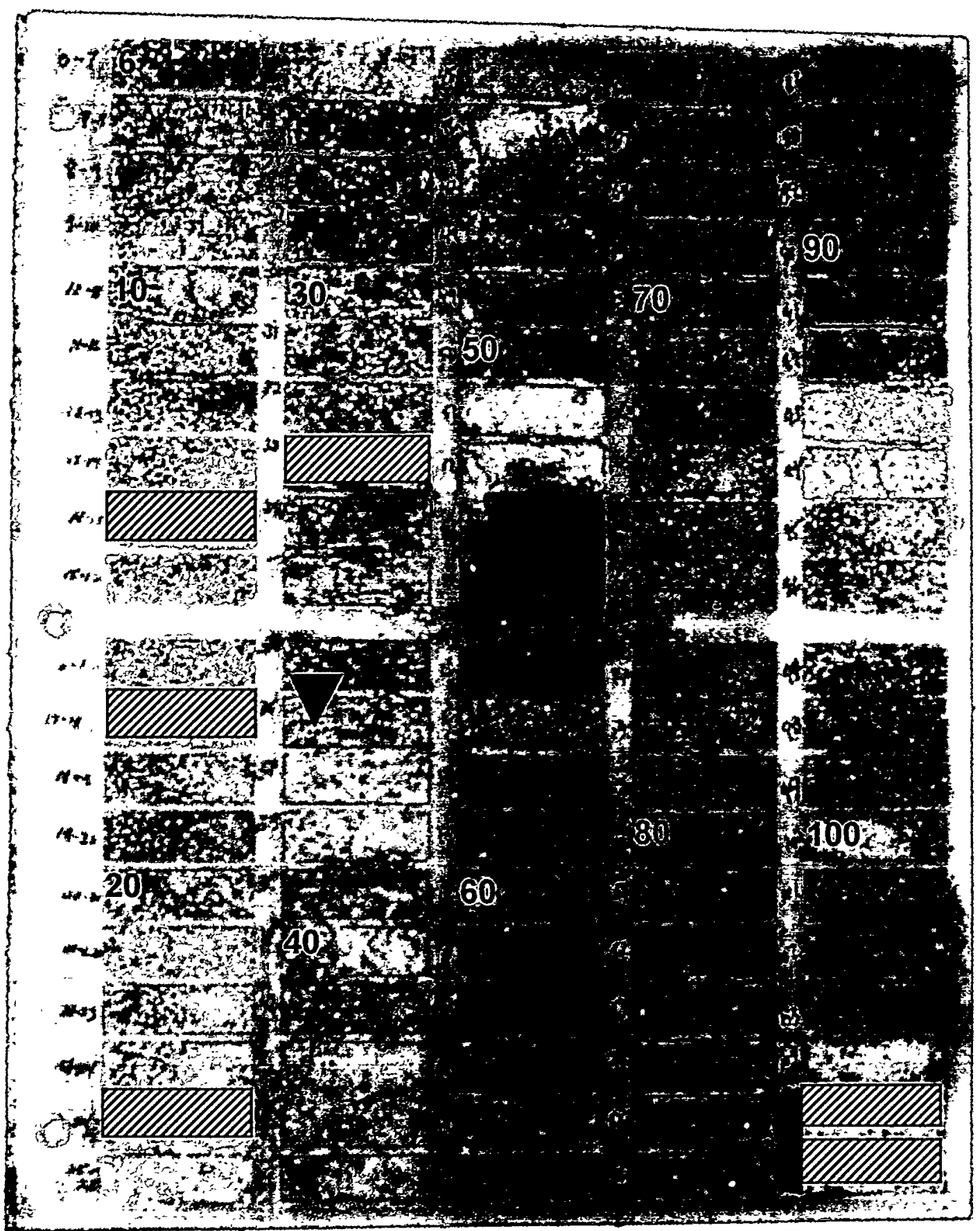

Figure 3.2-2. Photograph of subsurface sediments from boring SDFB-B1. Each box represents one foot of sediment. Shallower samples are in the upper left and deeper samples in the lower right. The numbers represent depth below the surface in ten foot increments. The striped boxes represent intervals where no sample was recovered. The triangle is located at the approximate water table horizon. 


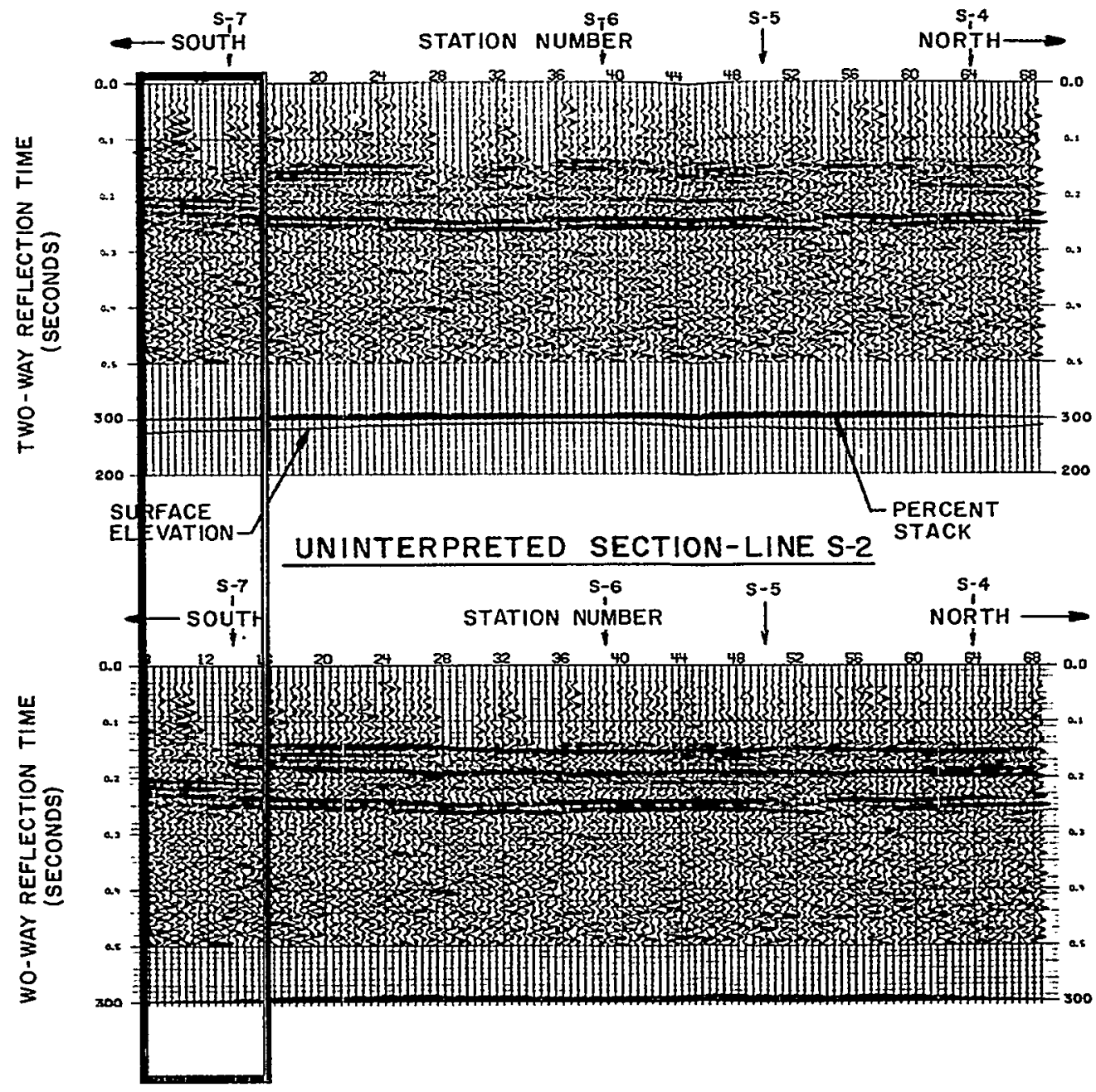

Figure 3.4-1. DWPF seismic line S-2 (refer to Figure 1.0-1). The box outlines the approximate area of SDF Site $B$ relative to this seismic line. This seismic line crosses Site $B$ on its southernmost end. The interpreted data represent horizons that were used for local subsurface mapping for the DWPF. The seismic data in this portion of the line are not in full fold and no geological structure is evident. These data are from D'Appolonia (1982b). 


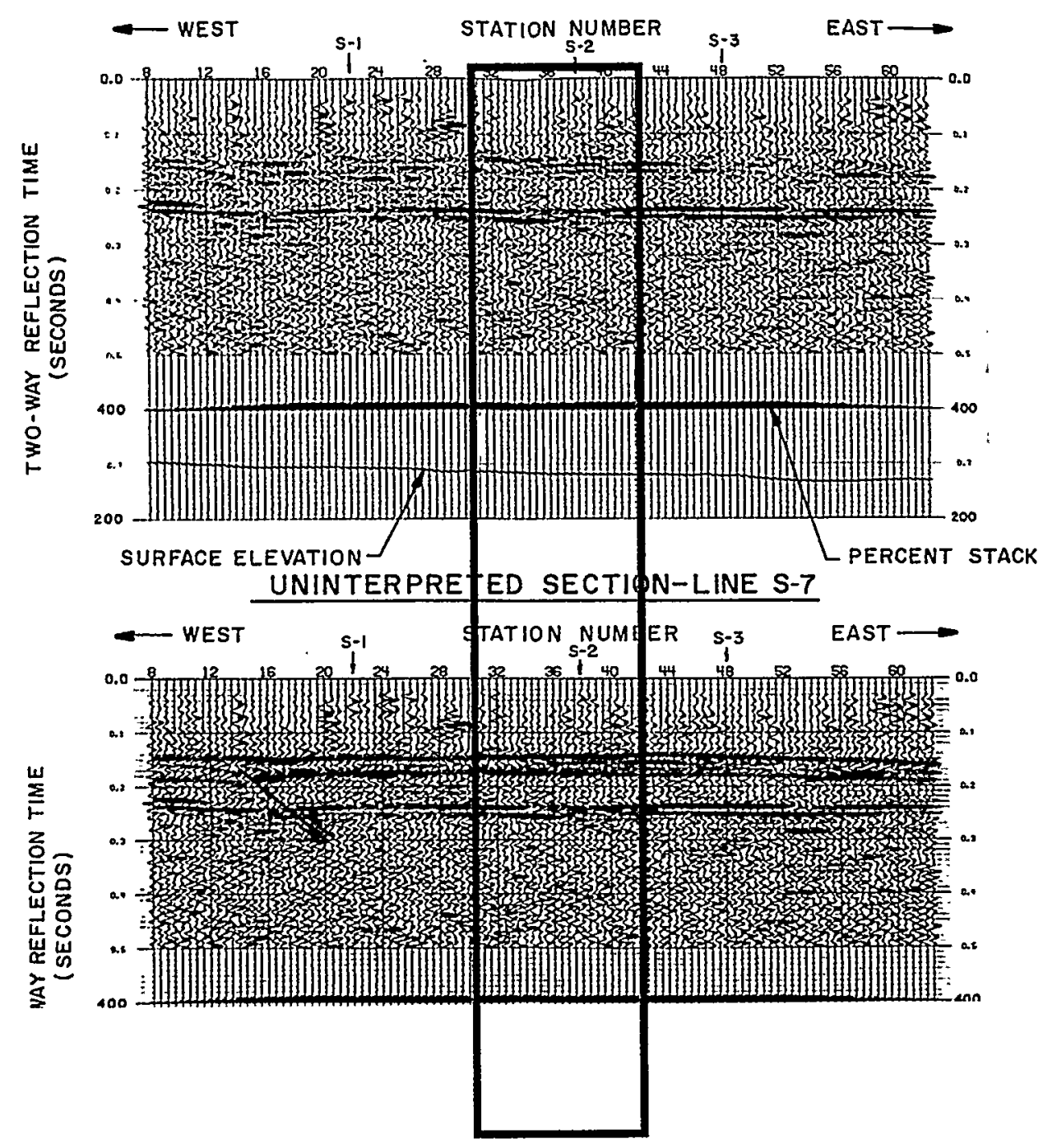

Figure 3.4-2. DWPF seismic line S-7 (refer to Figure 1.0-1). The box outlines the approximate area of SDF Site B relative to this seismic line. This seismic line was acquired approximately 100 feet to the northwest of Site $B$. The interpreted data represent horizons that were used for local subsurface mapping for the DWPF. No geological structure is seen in these data. These data are from D'Appolonia (1982b). 
SDF Site B

Engineering Layers

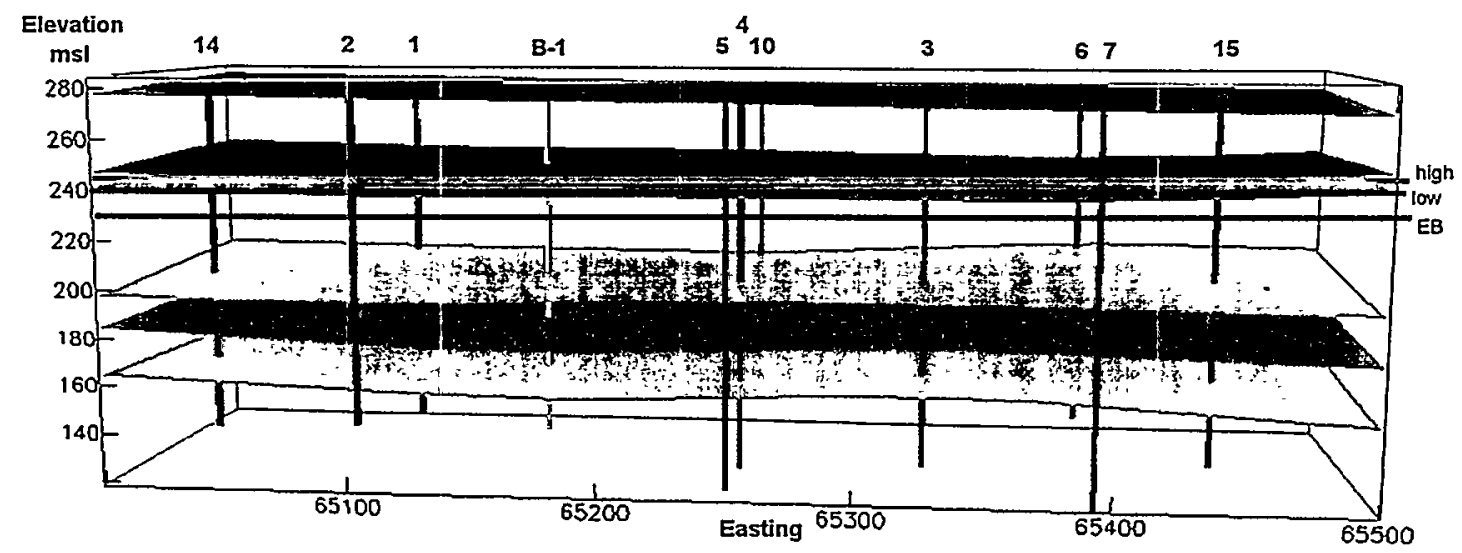

\footnotetext{
$6 \longdiv { I ^ { 2 } }$ Layer 7 top

$5 \square$ Layer IA top

$4 \quad$ Layer 2 top

3 Layer 3 top

2 Layer 4 top

$1 \square$ Layer 5 top

$Z$ exaggeration: 1.0

Azimuth: $\quad 6.13$

Inclination: $\quad 8.66$
}

Figure 3.4-3. Engineering layer model for the Site B strata. 'low' is the water table measured from the CPT data at the time of the investigation, which corresponds with the historical low value. The light blue line labeled 'high' is the highest water table measured in the adjacent monitoring well SBG-4 over the last five years. The red line, labeled 'EB' is the anticipated excavation base for the proposed Small-Tank Precipitation canyon facility. View is facing SRS north. The CPT's and boring B-1 are labeled. Depths are in feet relative to mean sea level. 
Site Geotechnical Services

Preliminary Siting Characterization

Salt Disposition Facility - Site B (U)

A SDFBC14

FEEI

HO THOSS
SDFBBI

FEET

NOL IYOSS
SDFBC1

FEEI

NDD TVOSS

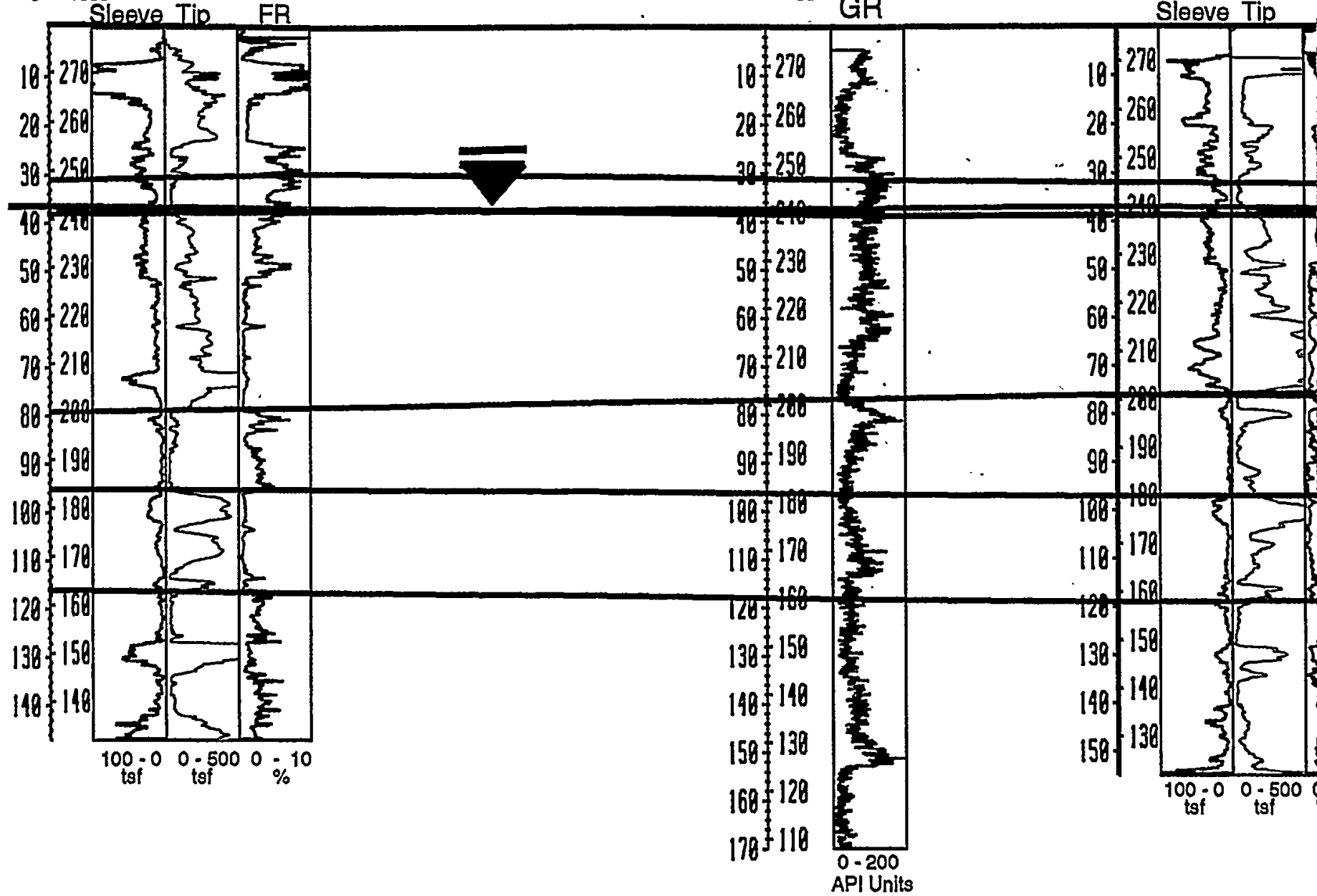

V.E. $=2 x$

$M D=$ measured depth from surface

TVDSS = true vertical depth, subsea 
Site Geotechnical Services

Preliminary Siting Characterization

K-TRT-S-00001

Rev. 0

Salt Disposition Facility - Site B (U)

July 1999

\section{SDF SITE B \\ Tip Stress}

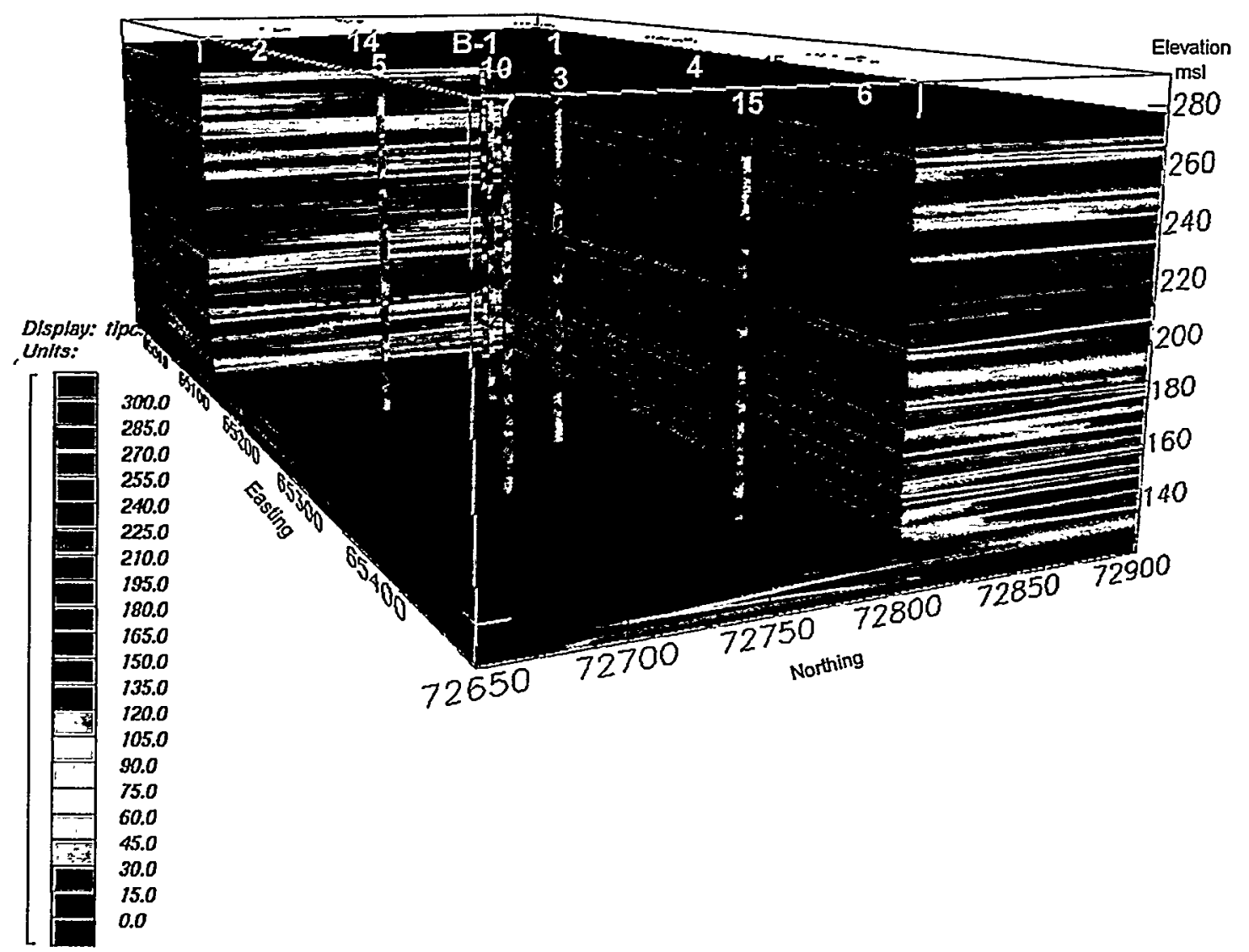

Figure 3.4-5. Three-dimensional model of measured tip stresses from the CPT data. Each CPT is numbered according to the layout pattern on Figure 1.0-1. View is to the northwest towards the DWPF facility. Depths are in feet. The coordinate system shows SRS Northing and Easting. Red colors indicate low tip stresses (generally clayey soils) and blue colors high tip stresses (generally sandy soils). The vertical and lateral variation in subsurface sediments is obvious in this figure. 


\section{SDF Site B \\ Friction Ratio}

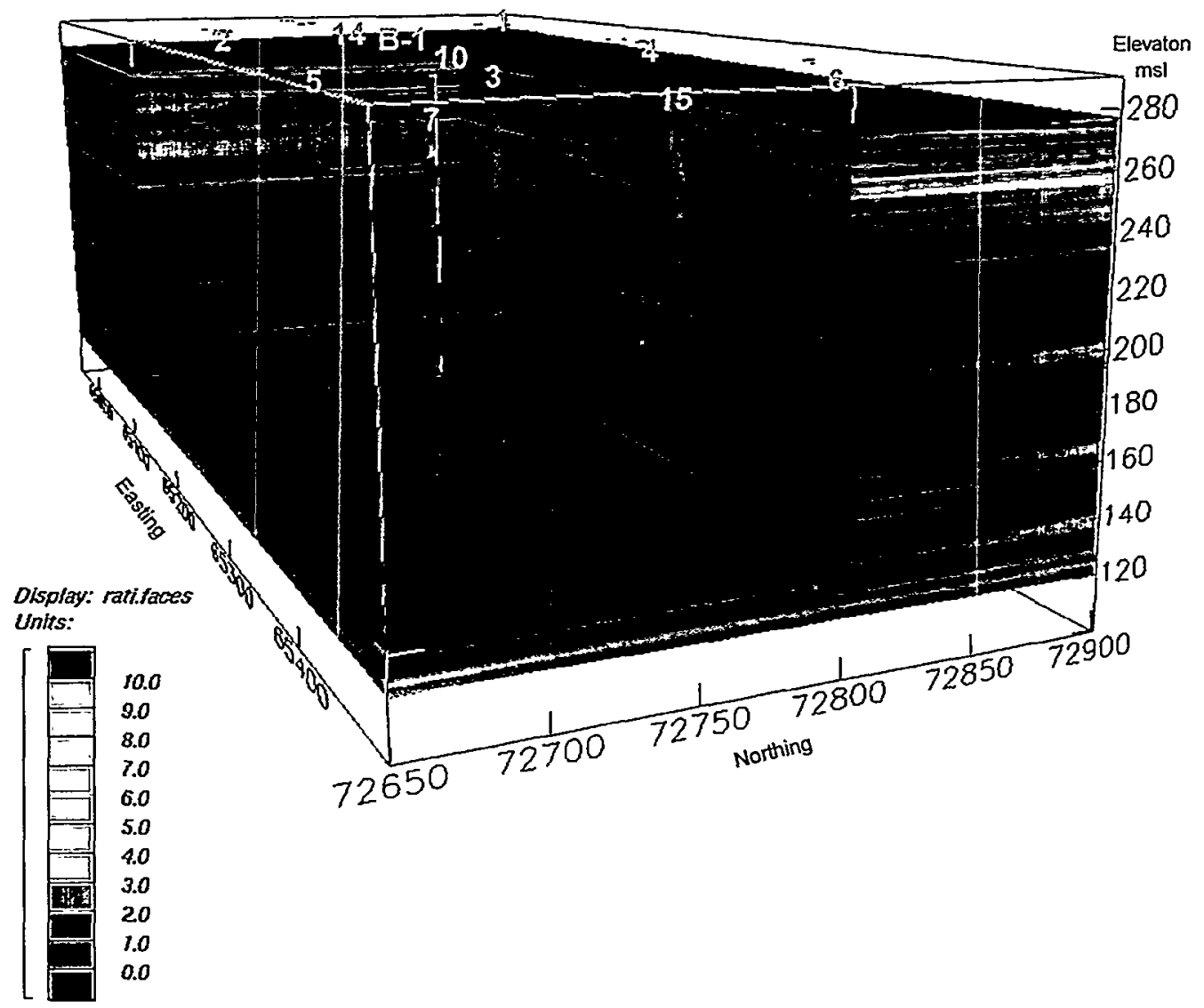

Figure 3.4-6. Three-dimensional model of the Friction Ratio based on the CPT data. Darker blue colors indicate soils that are mostly sand. Lighter blues and greens indicate soils that have are higher in clay content. View is to the northwest. Depth is in feet relative to mean sea level. Coordinates are in SRS Northing and Easting. This figure demonstrates the relative variation in grain size (sand versus finer grained sediments) underlying the site. 


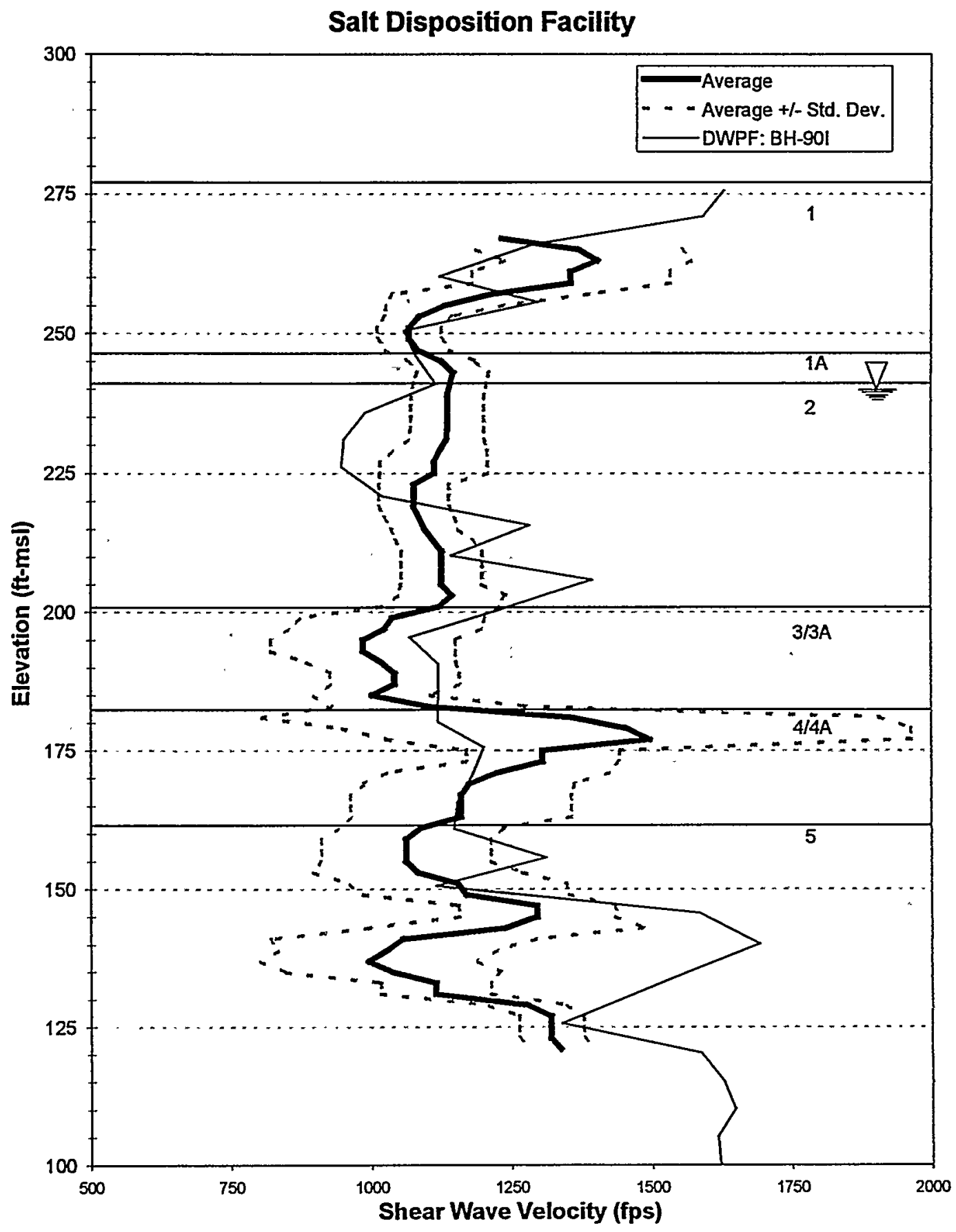

Figure 3.6-1. Average shear wave velocity from CPT's on Site B as compared to historical DWPF data. Engineering layers from Site B are shown. 


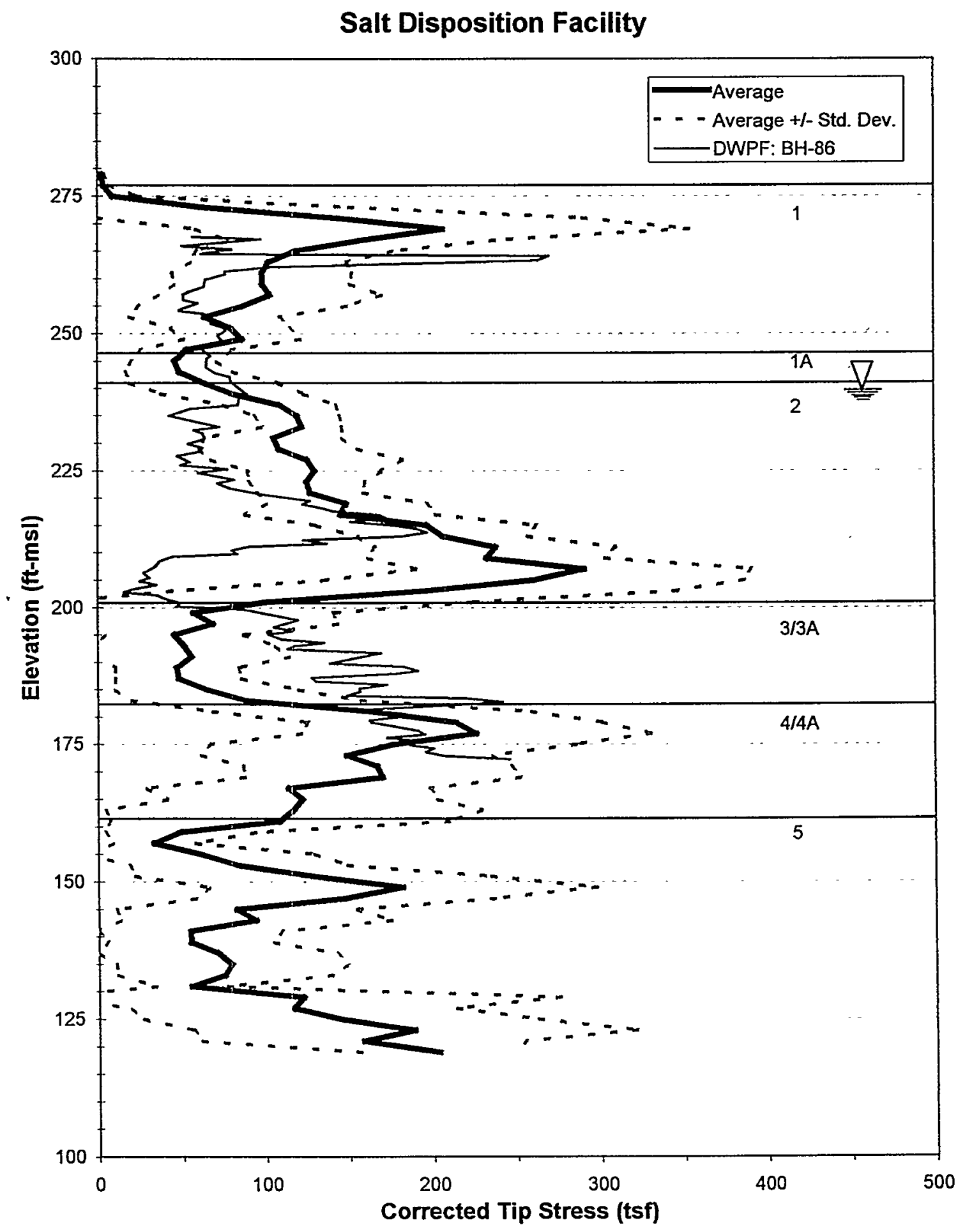

Figure 3.6-2. Tip Stress averaged from the Site B CPT's compared to DWPF data. The engineering layering from Site $B$ is shown. 


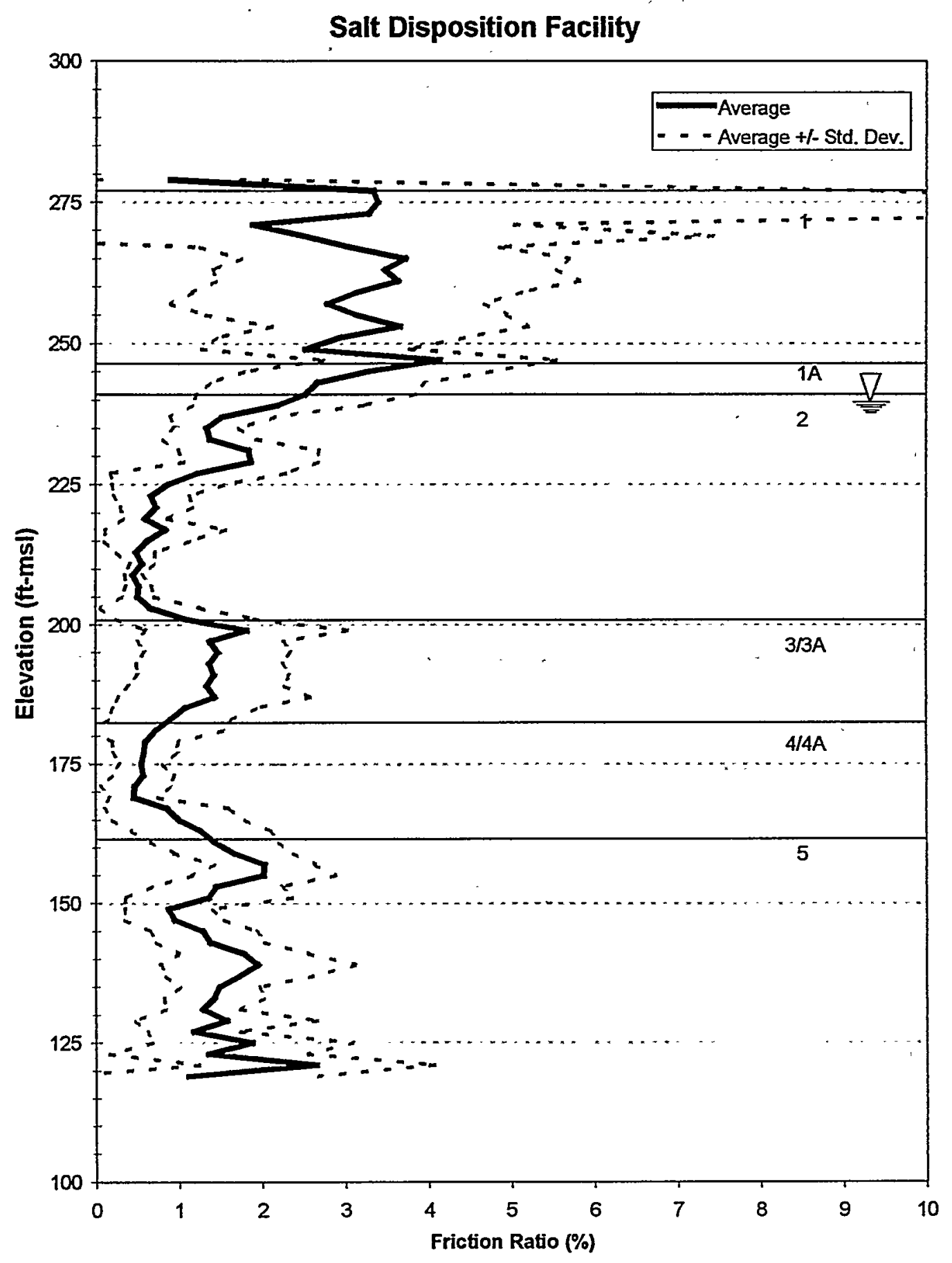

Figure 3.6-3. Averaged Friction Ratio from Site B compared with DWPF data. The Site B engineering layering is shown. 


\section{Salt Disposition Facility}

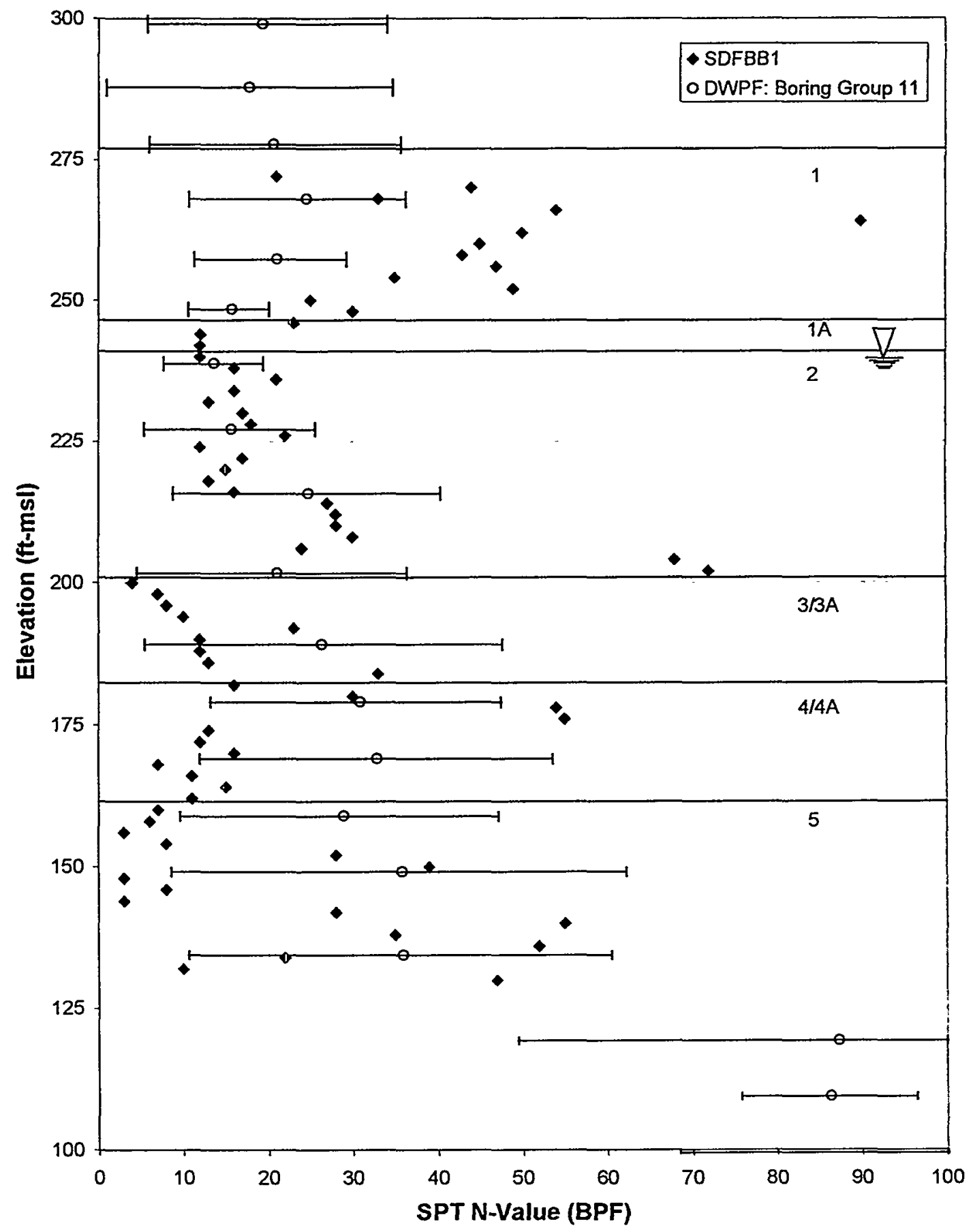

Figure 3.6-4. N-Value averaged for the Site B SPT and compared to historic DWPF data for each engineering layer. The error bars on the DWPF data represent 1 Standard Deviation. 


\section{SDF Site B}

\section{Soft Zone Indicator}

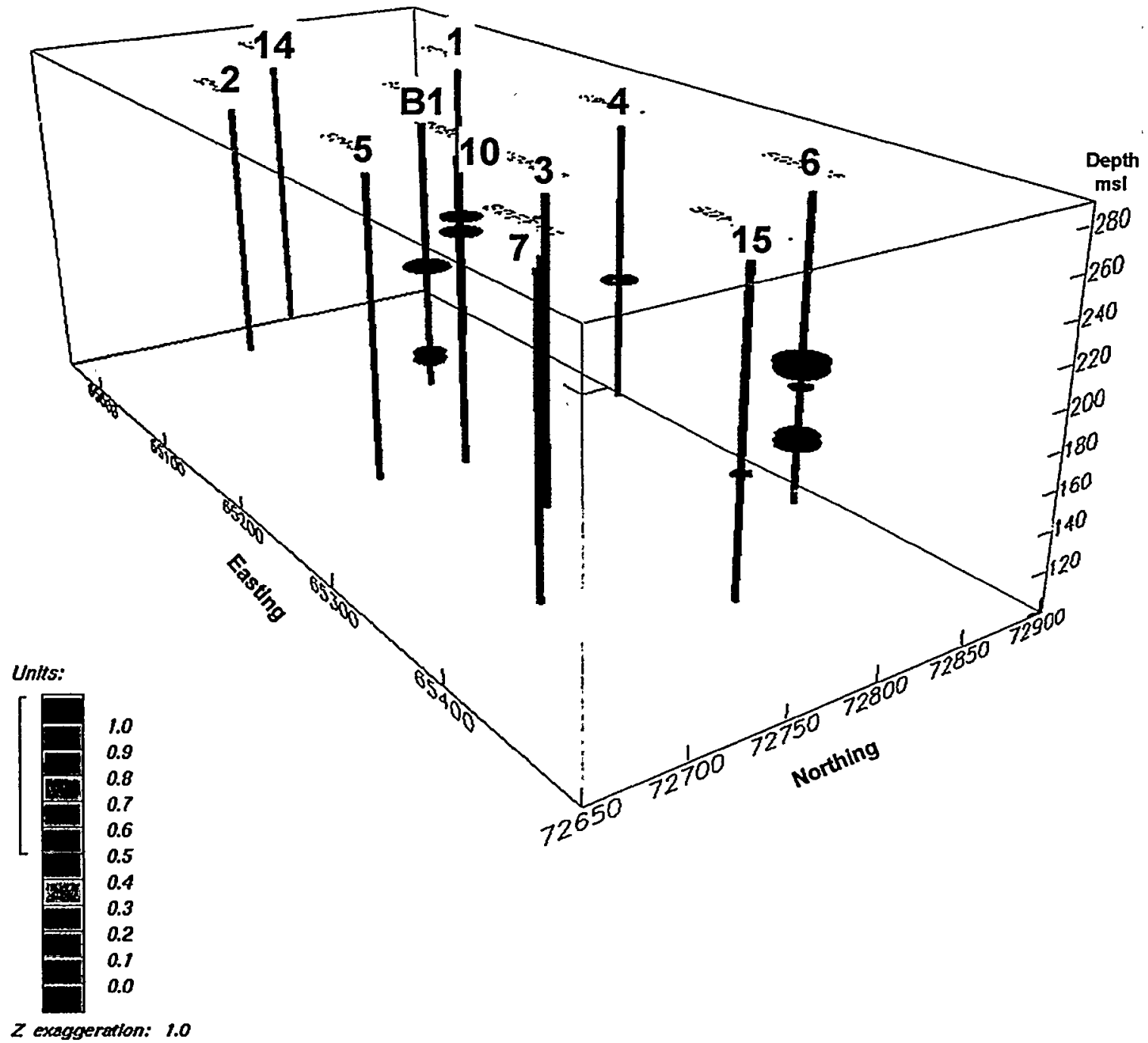

Figure 3.7-1. Interpreted soft zones based on the CPT data. The coordinates show SRS Northing and Easting. View is to the northwest. Elevations are in feet relative to mean sea level. Two soft zones are apparent in the northeastern portion of the site. The lateral variation of the soft zones may be an artifact of the modeling or sampling density and further investigation is necessary. 


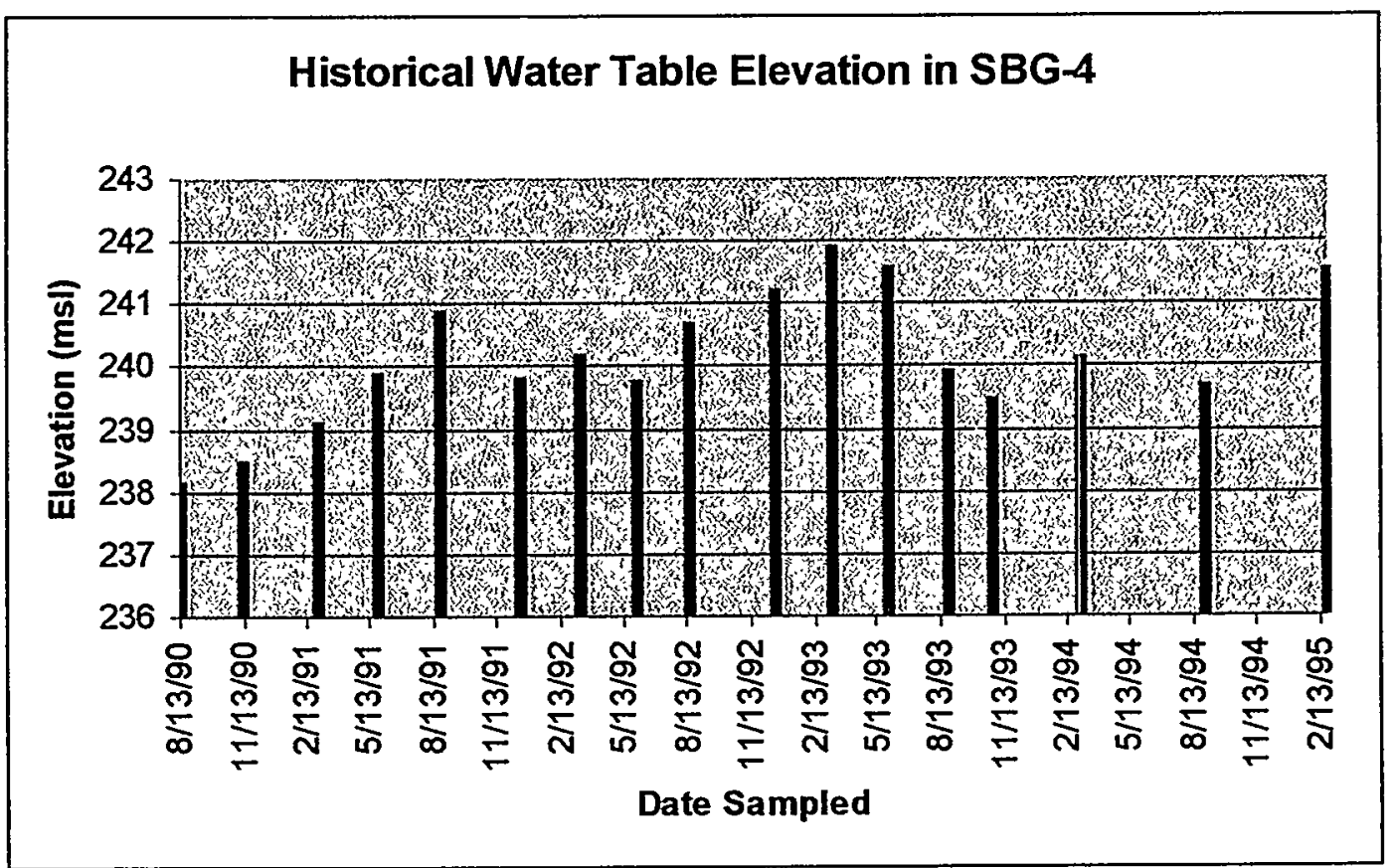

Figure 3.8-1. Comparison of historical water table elevations in monitoring well SBG-4 located adjacent to Site B. Low water table levels (approximately 238 feet relative to mean sea level) were measured in dry summer or drought conditions. Higher levels, approximately 242 feet) were measured in wetter years or during the winter season. 
This page intentionally left blank. 


\section{Appendix A}

SDFB-B1 Geotechnical Log 
This page intentionally left blank. 


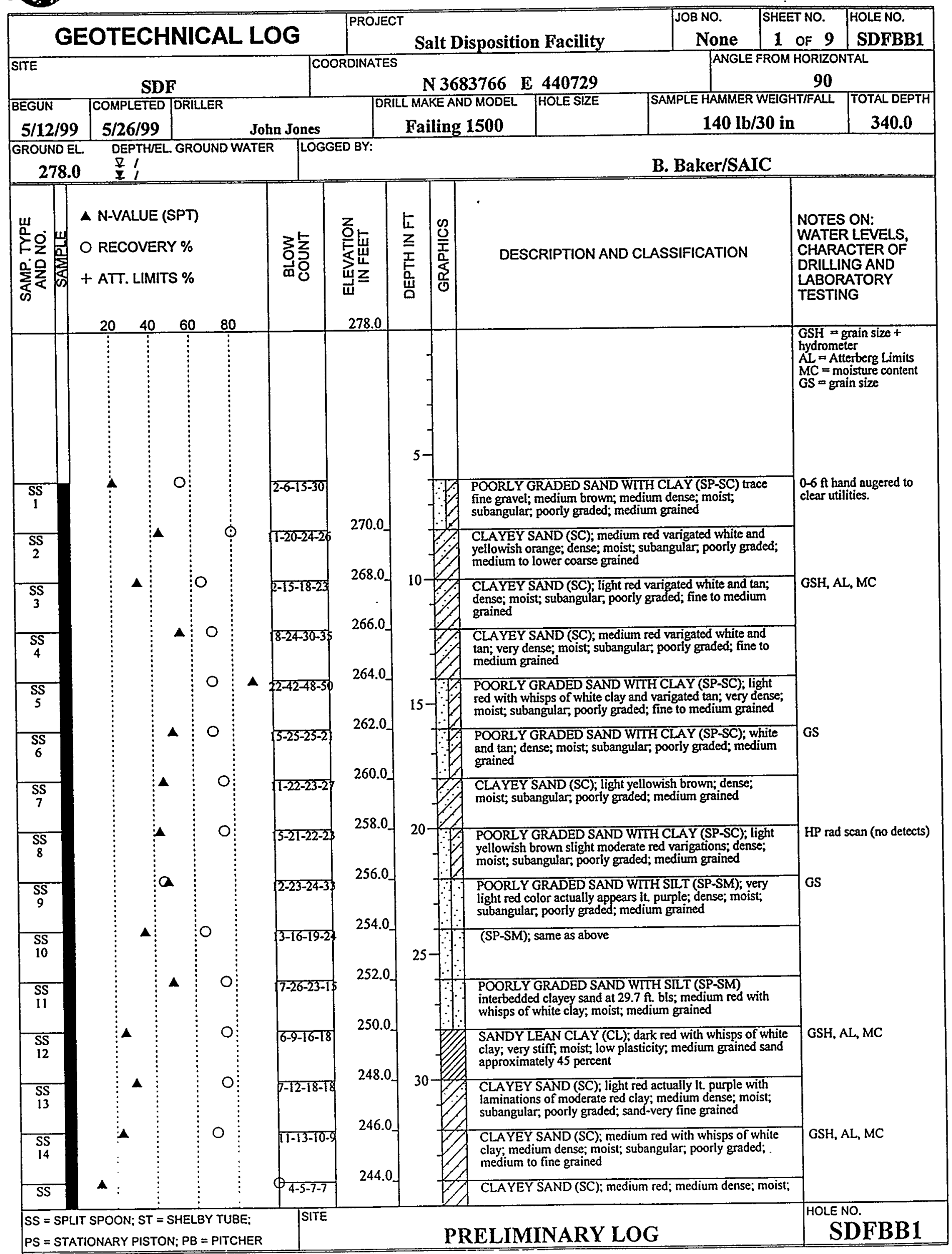




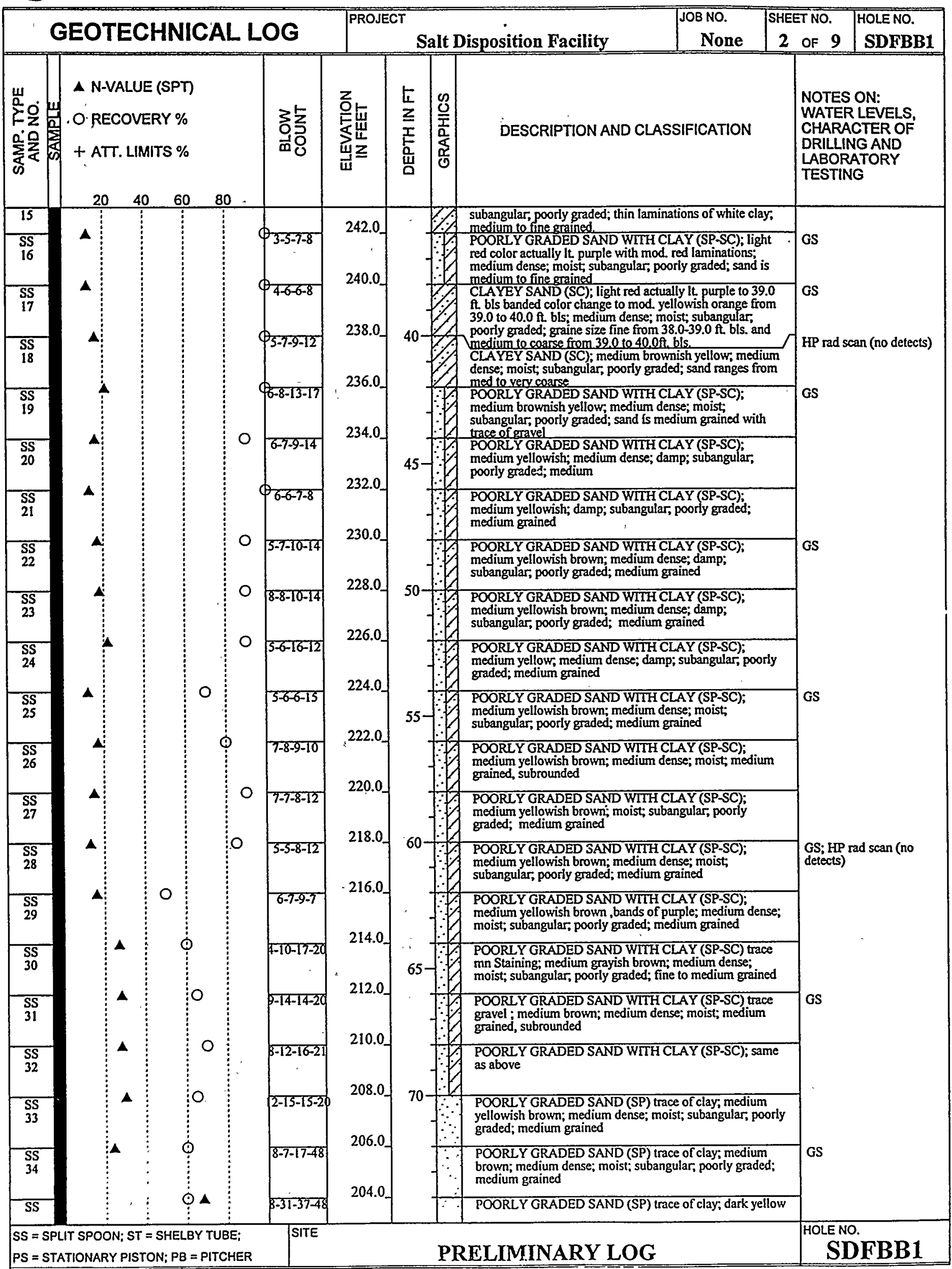




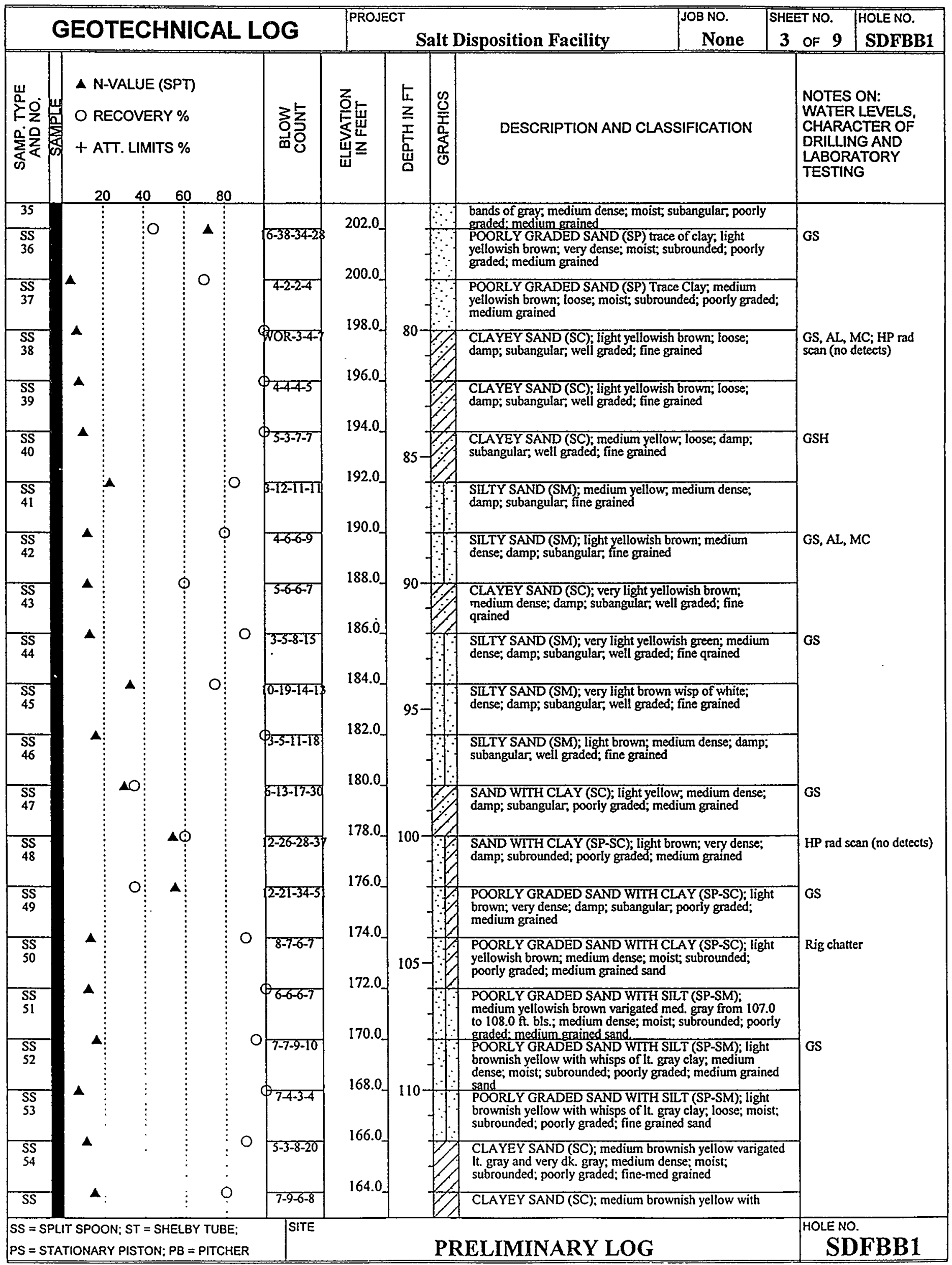




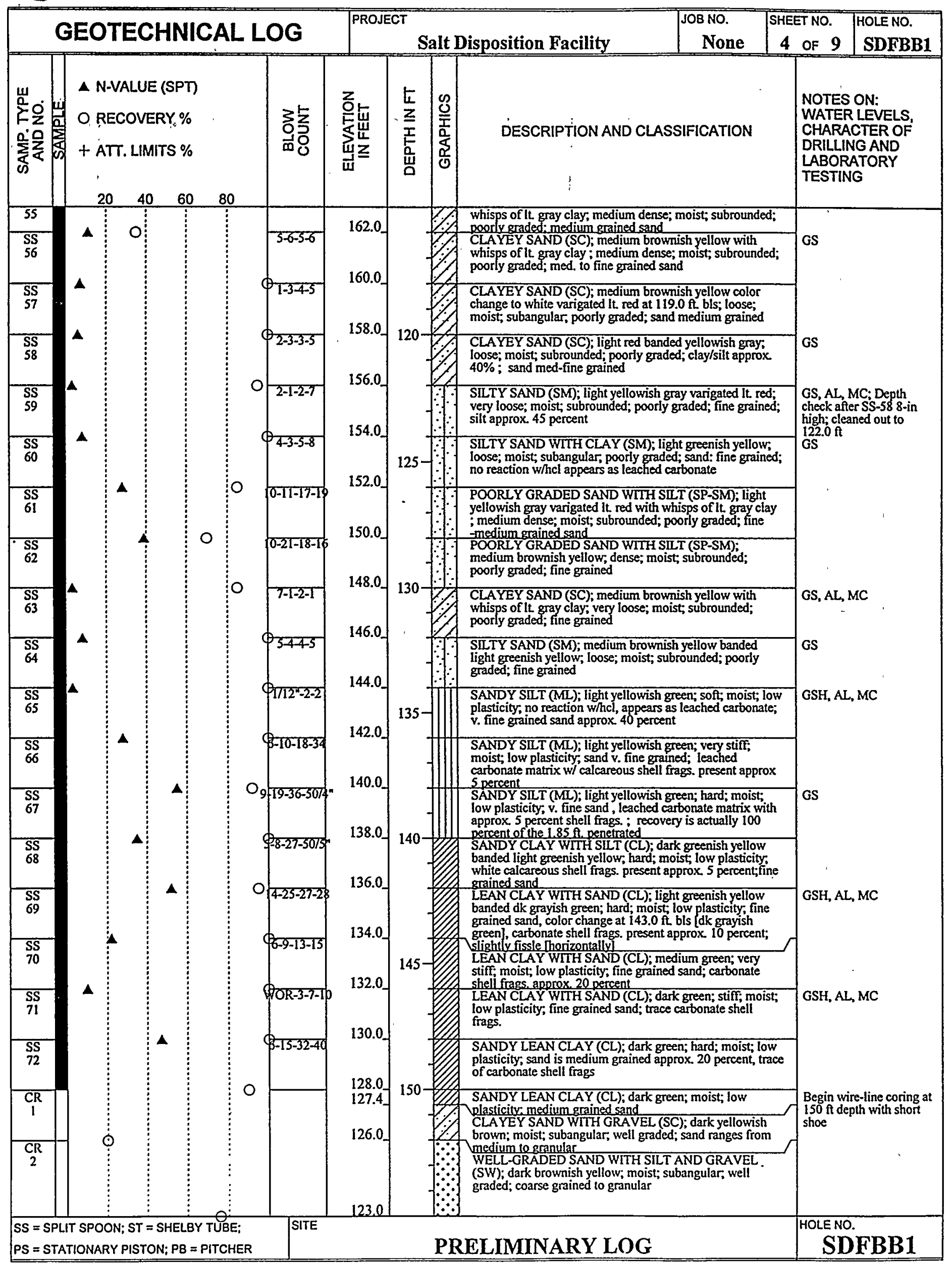




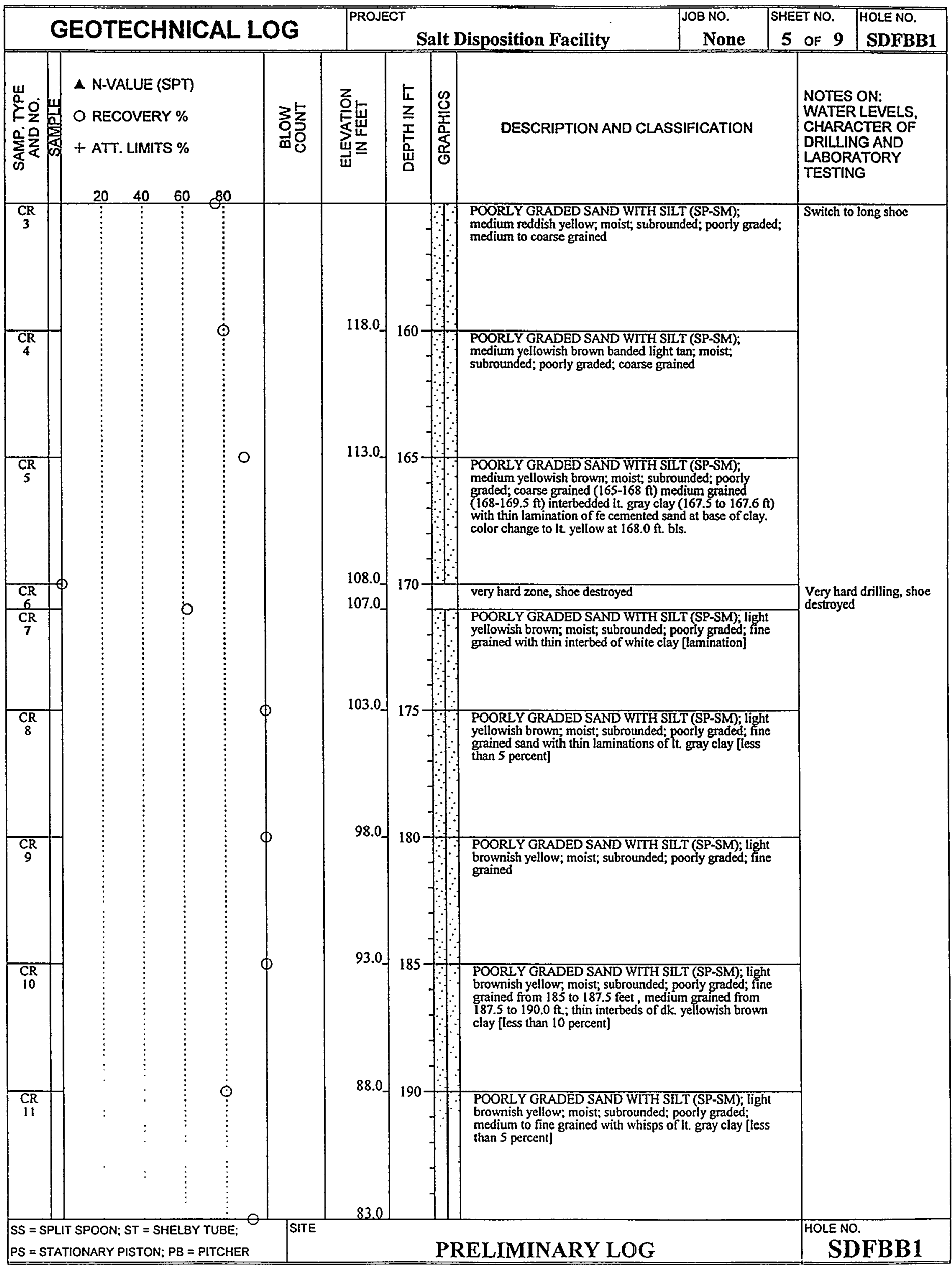




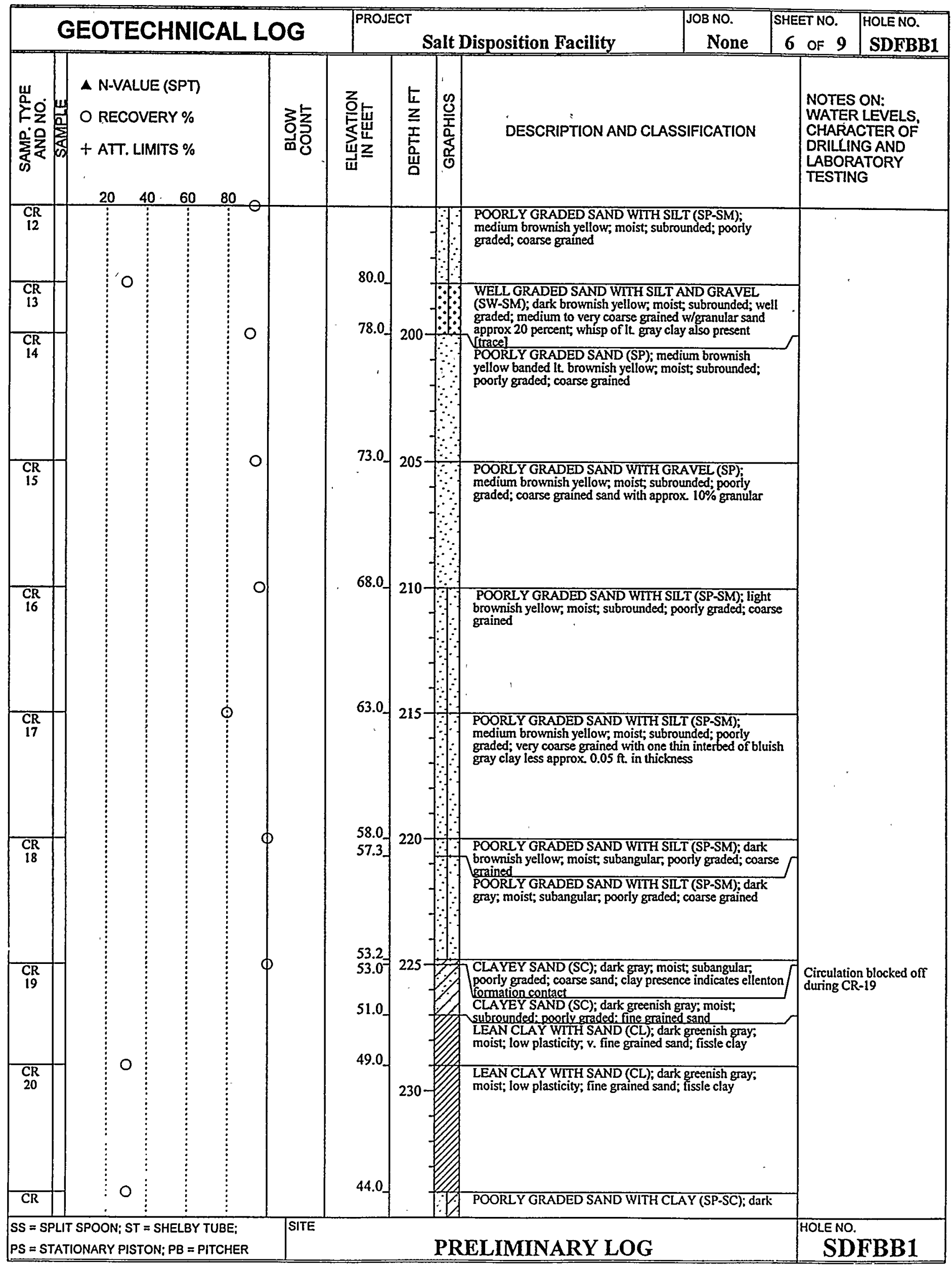




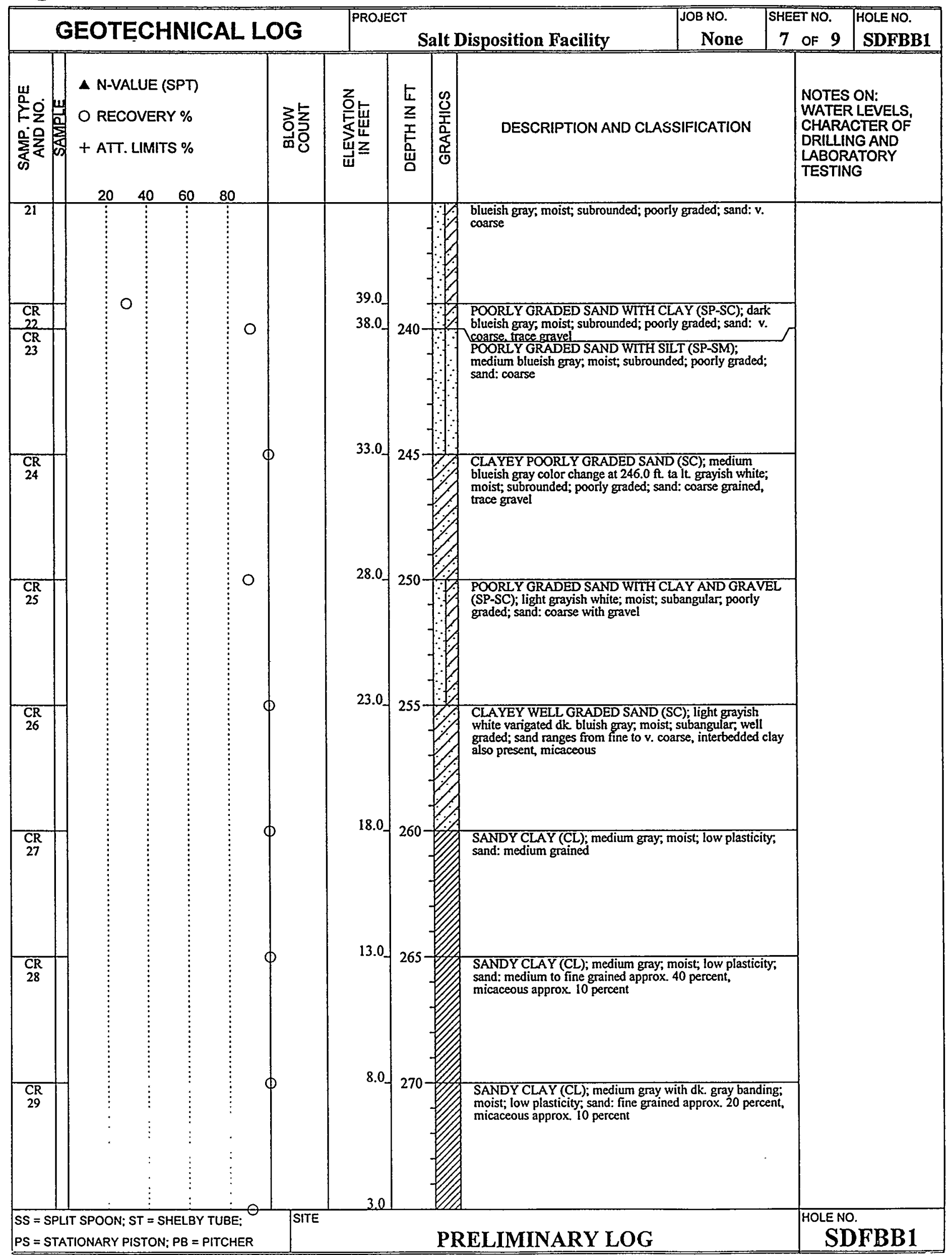




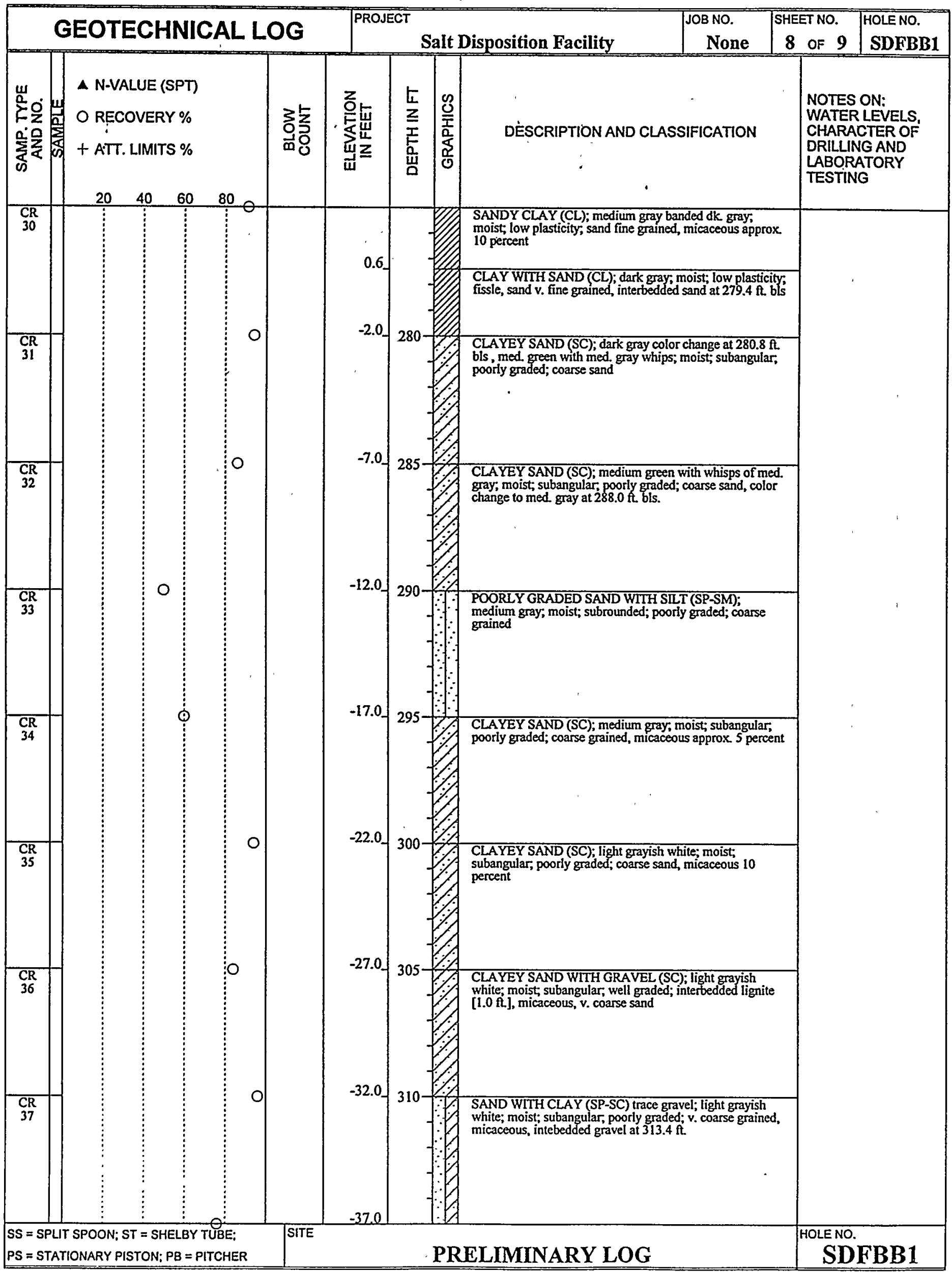




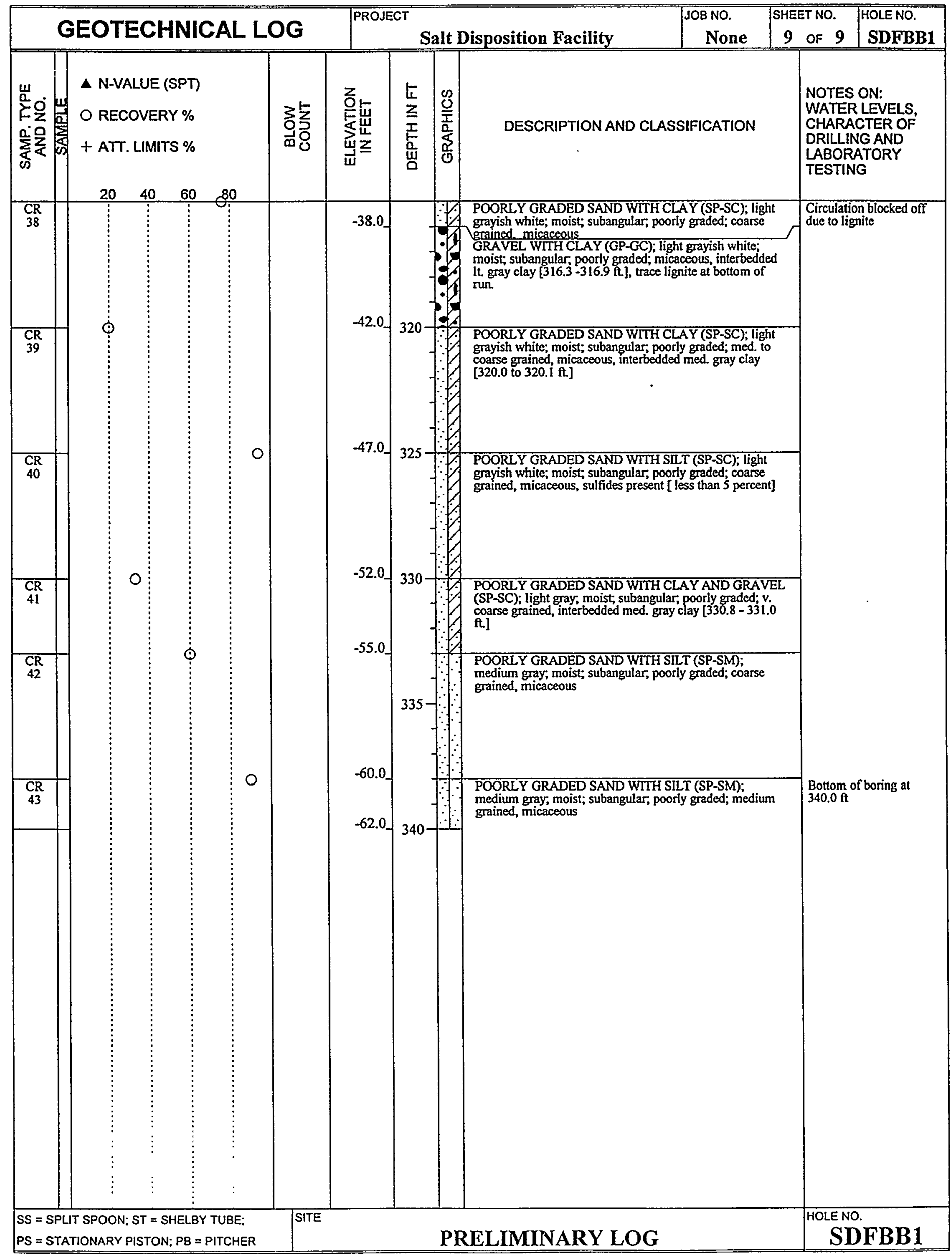


Appendix B

Seismic Cone Penetrometer Data 
This page intentionally left blank. 


\section{North 72703.0 East 65104.3 Elevation 277.0}
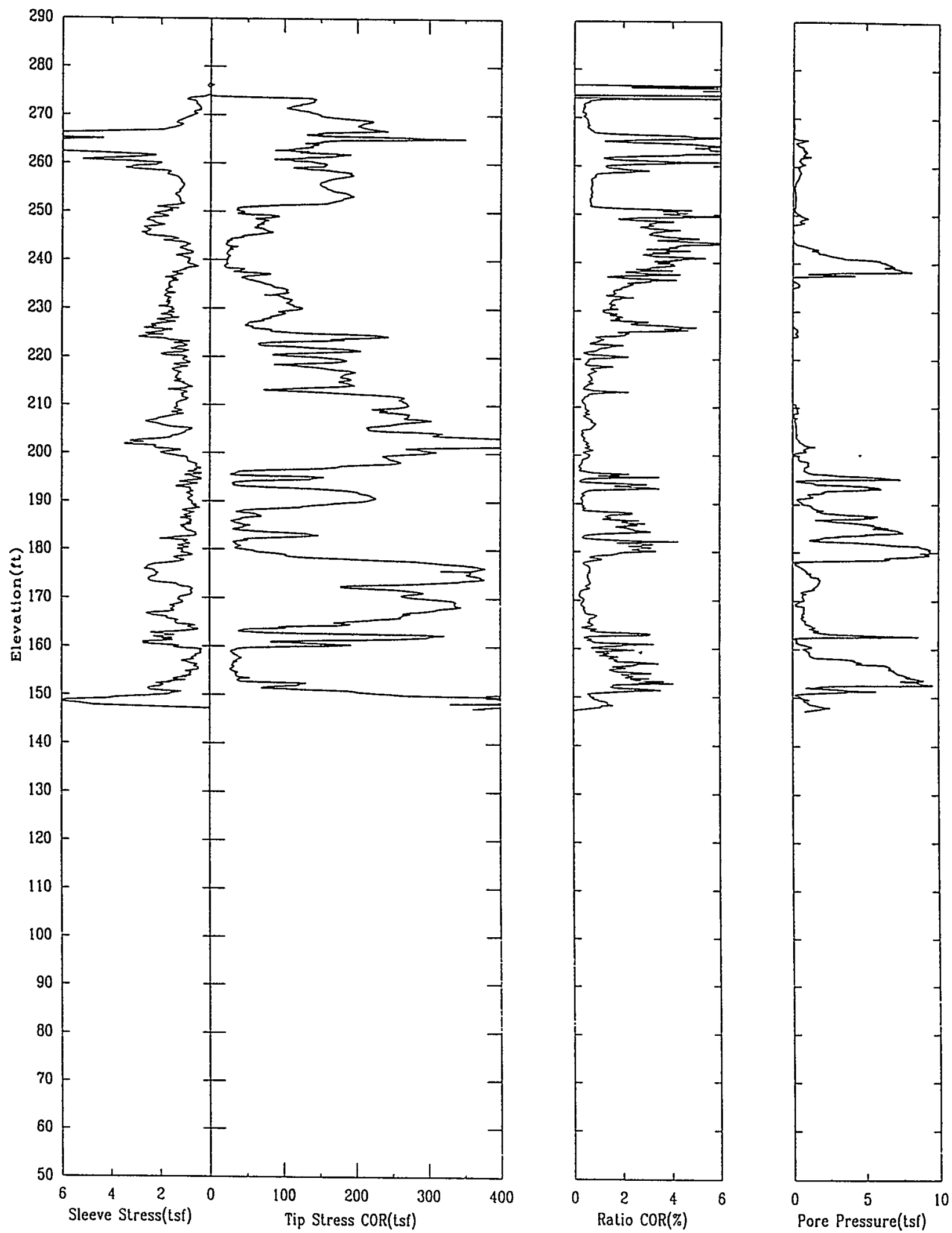
$\begin{array}{cccc}\text { SDFBC2 } & \text { APPLIED RESEARCH ASSOCIATES, INC. } & 04 / 27 / 99 \\ \text { North } 72703.0 & \text { East } 65104.3 & \text { Elevation } 277.0\end{array}$
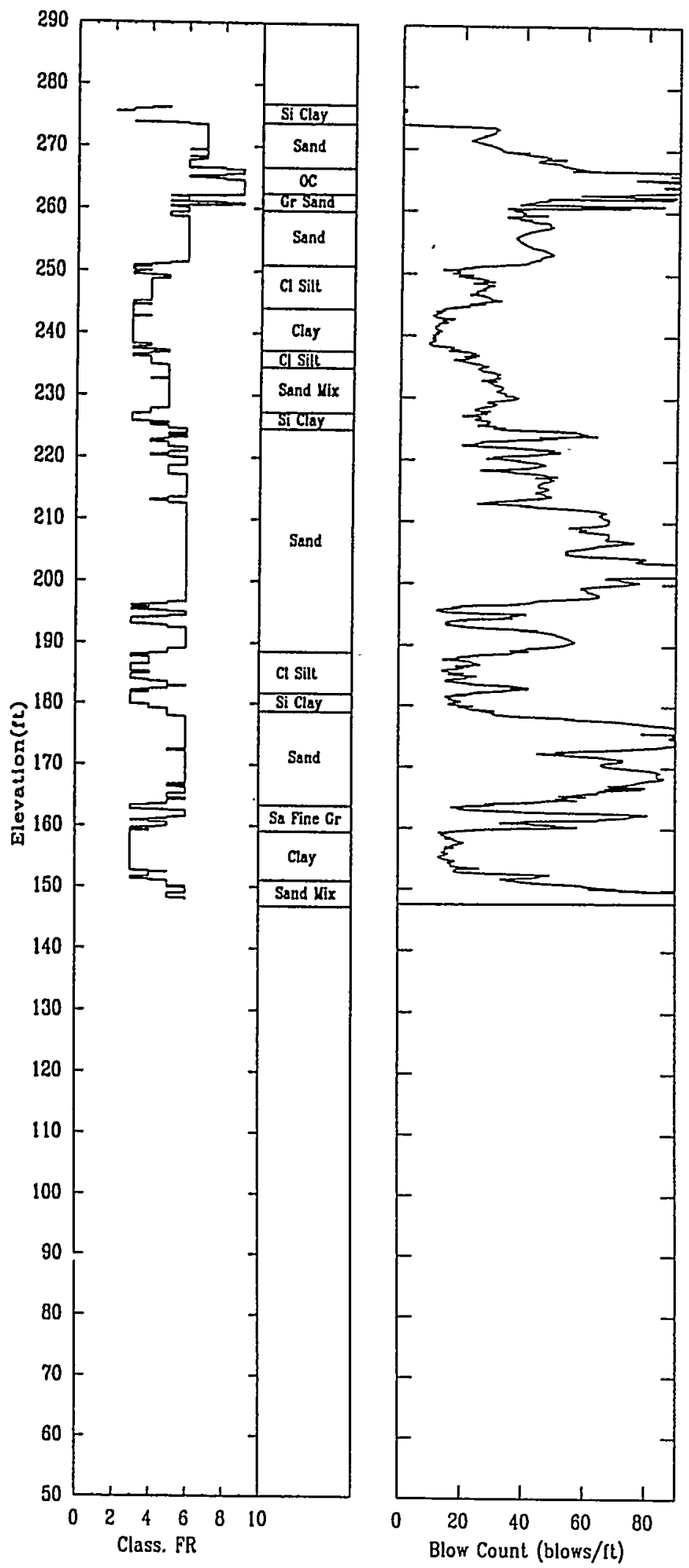


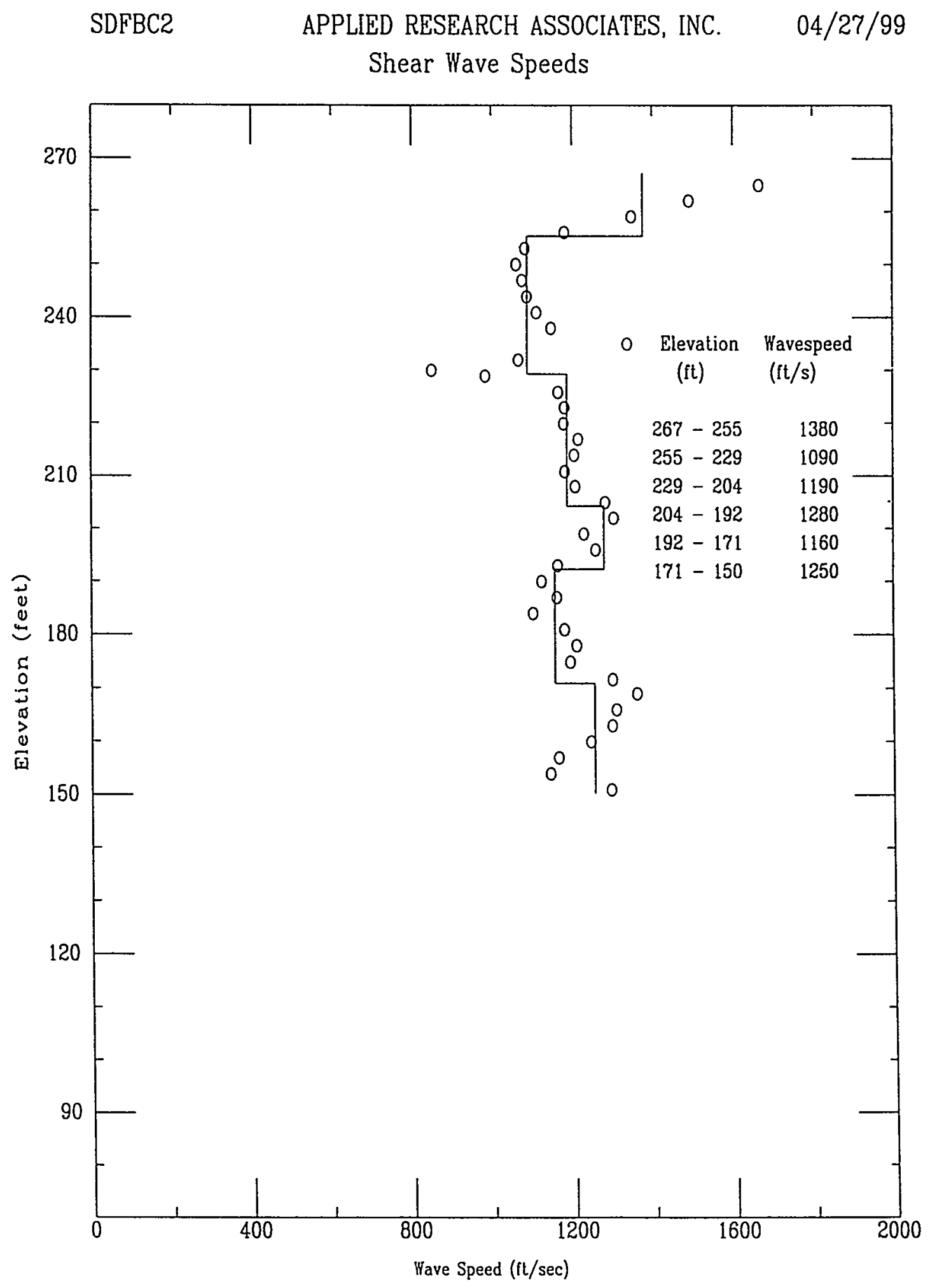

File 327A904S 


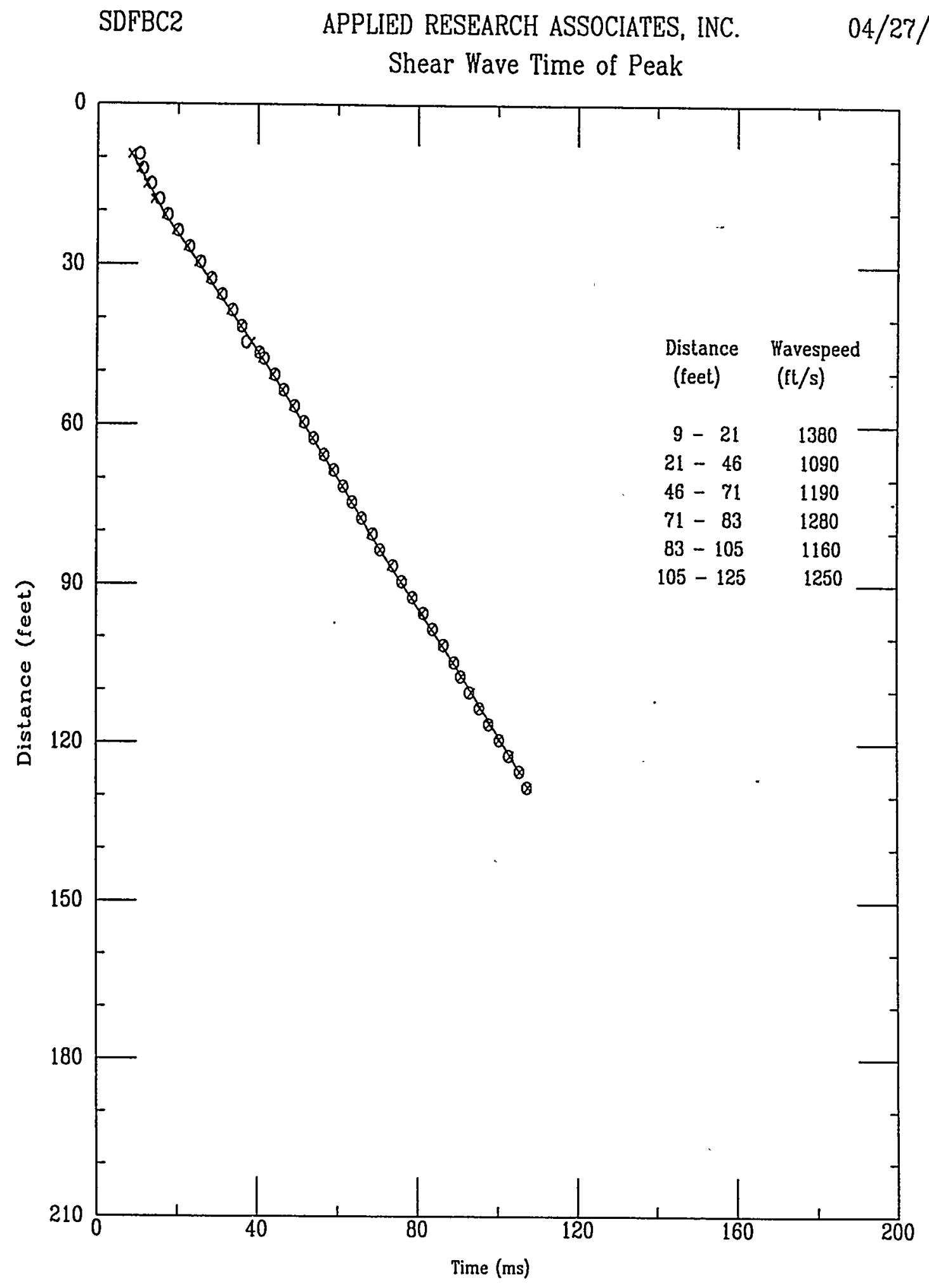

File 327A904S 
Applied Research Associates

SDFBC2

S Wave

$04 / 27 / 99$

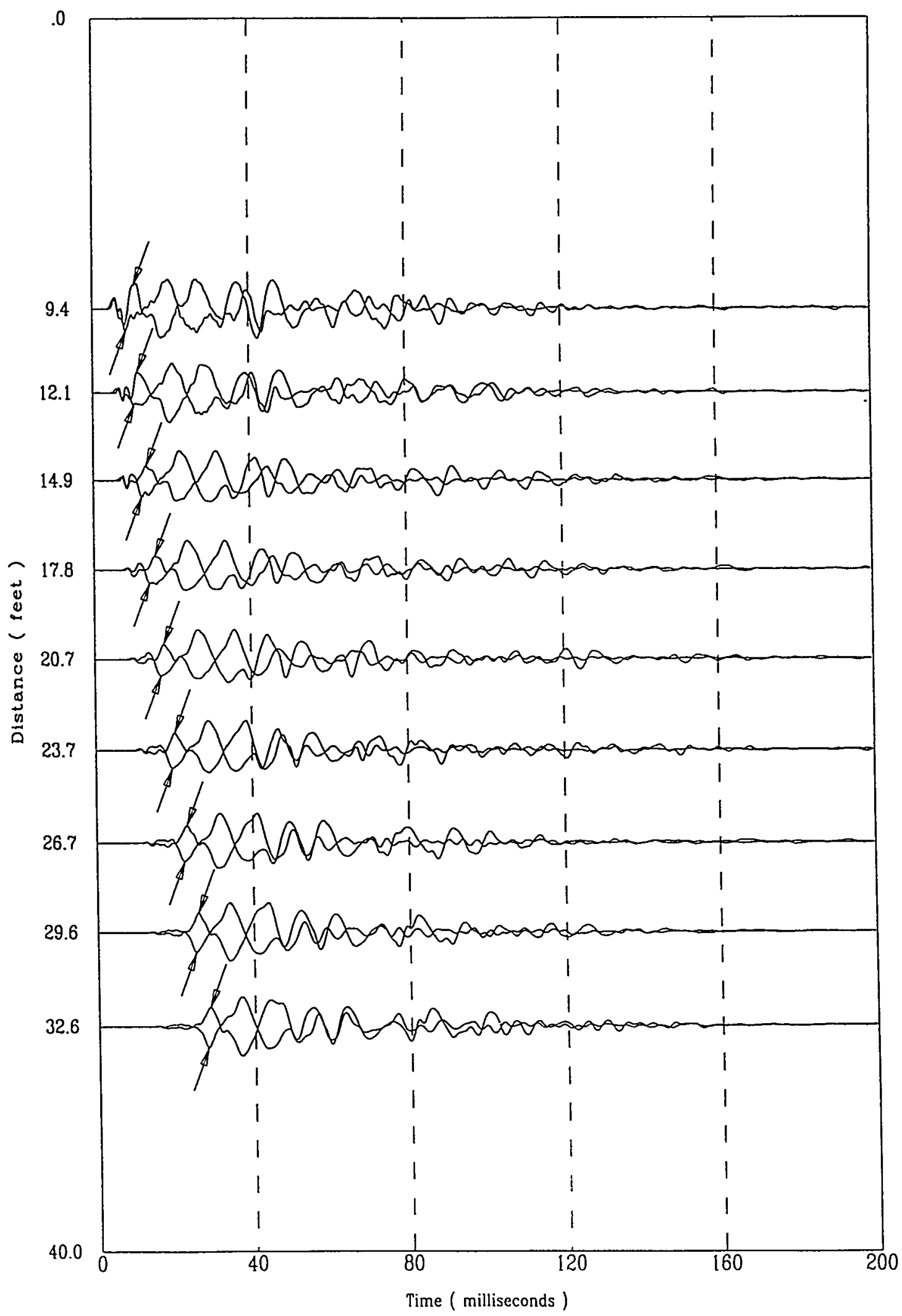


Applied Research Associates SDFBC2

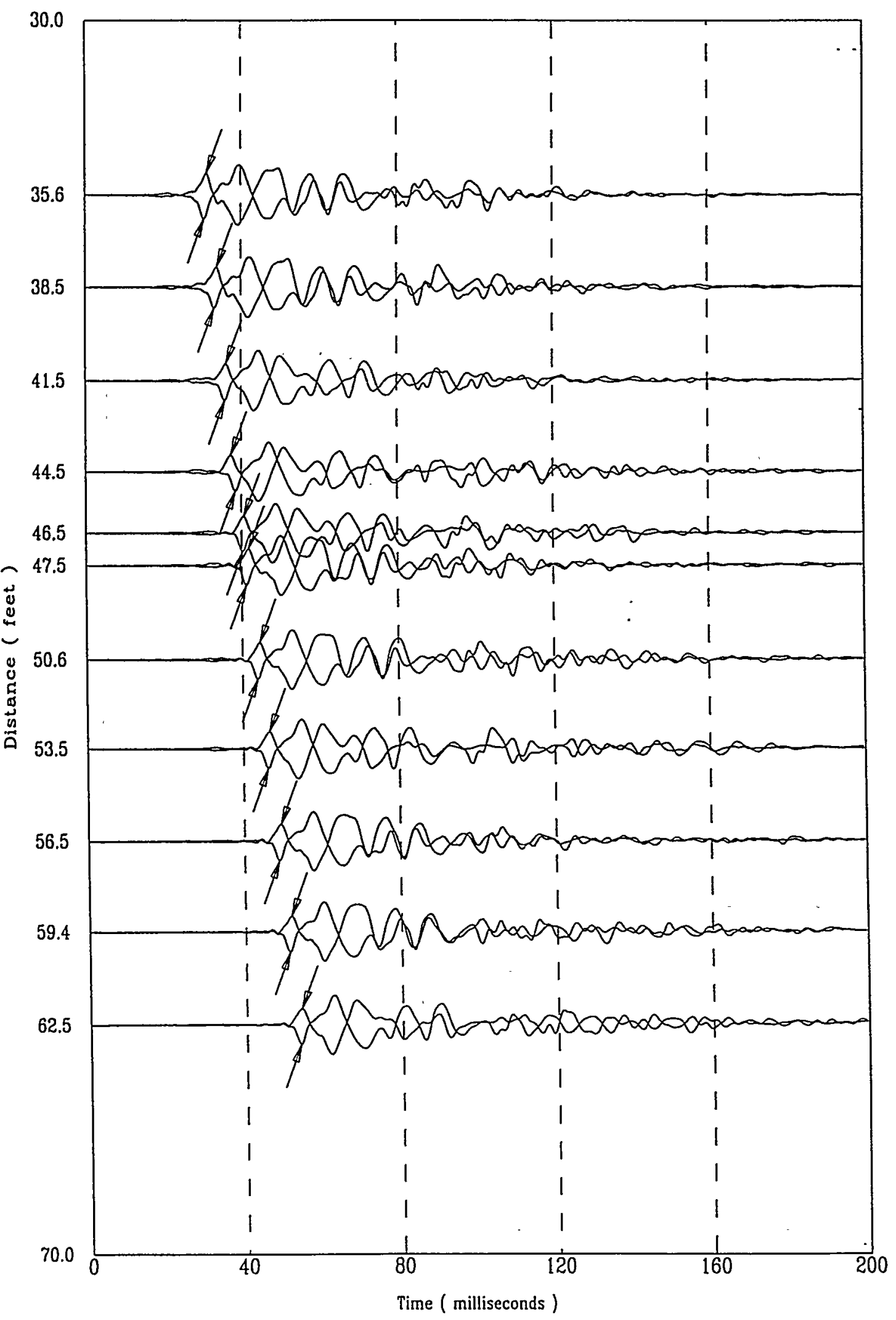


Applied Research Associates SDFBC2

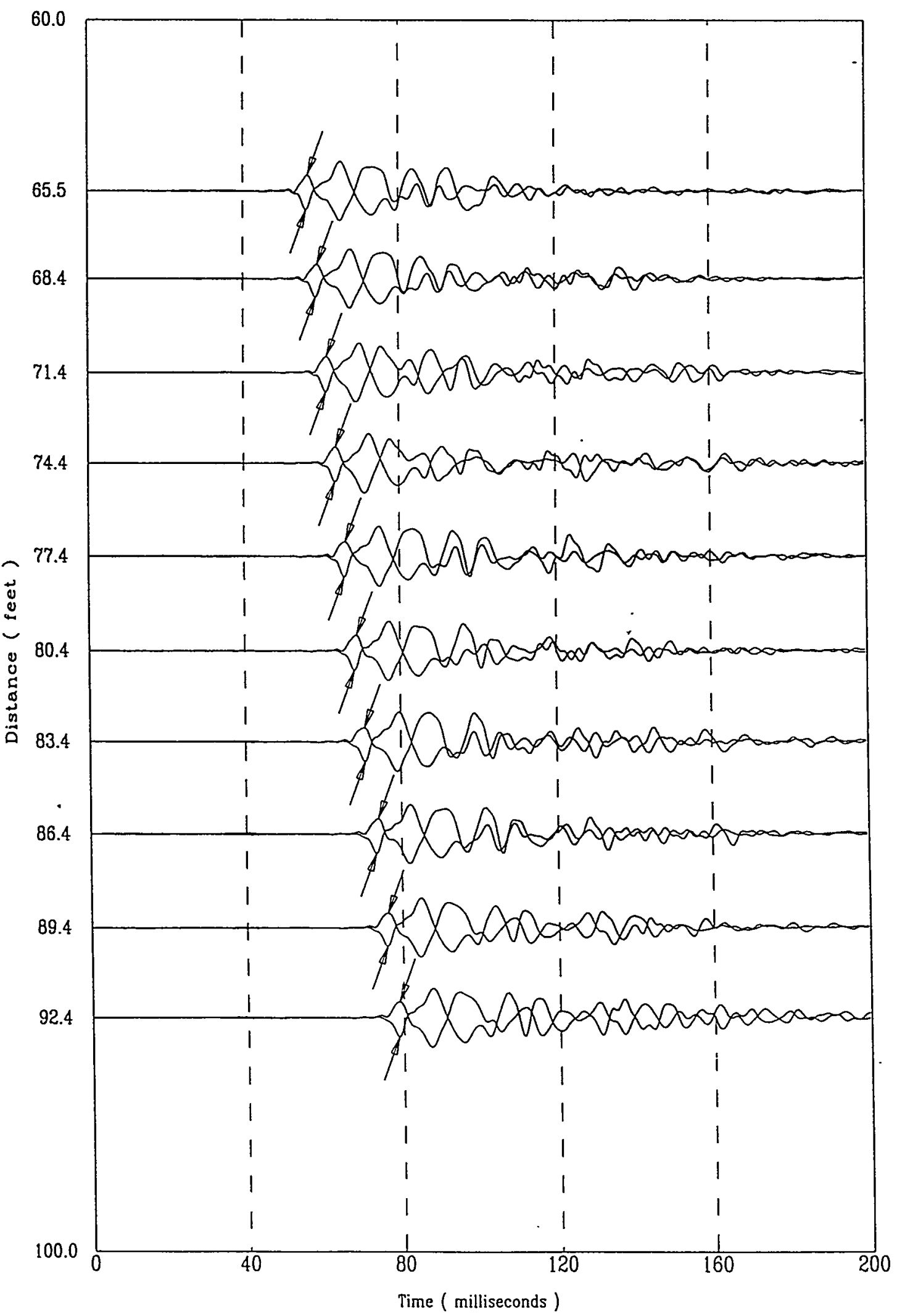


Applied Research Associates SDFBC2

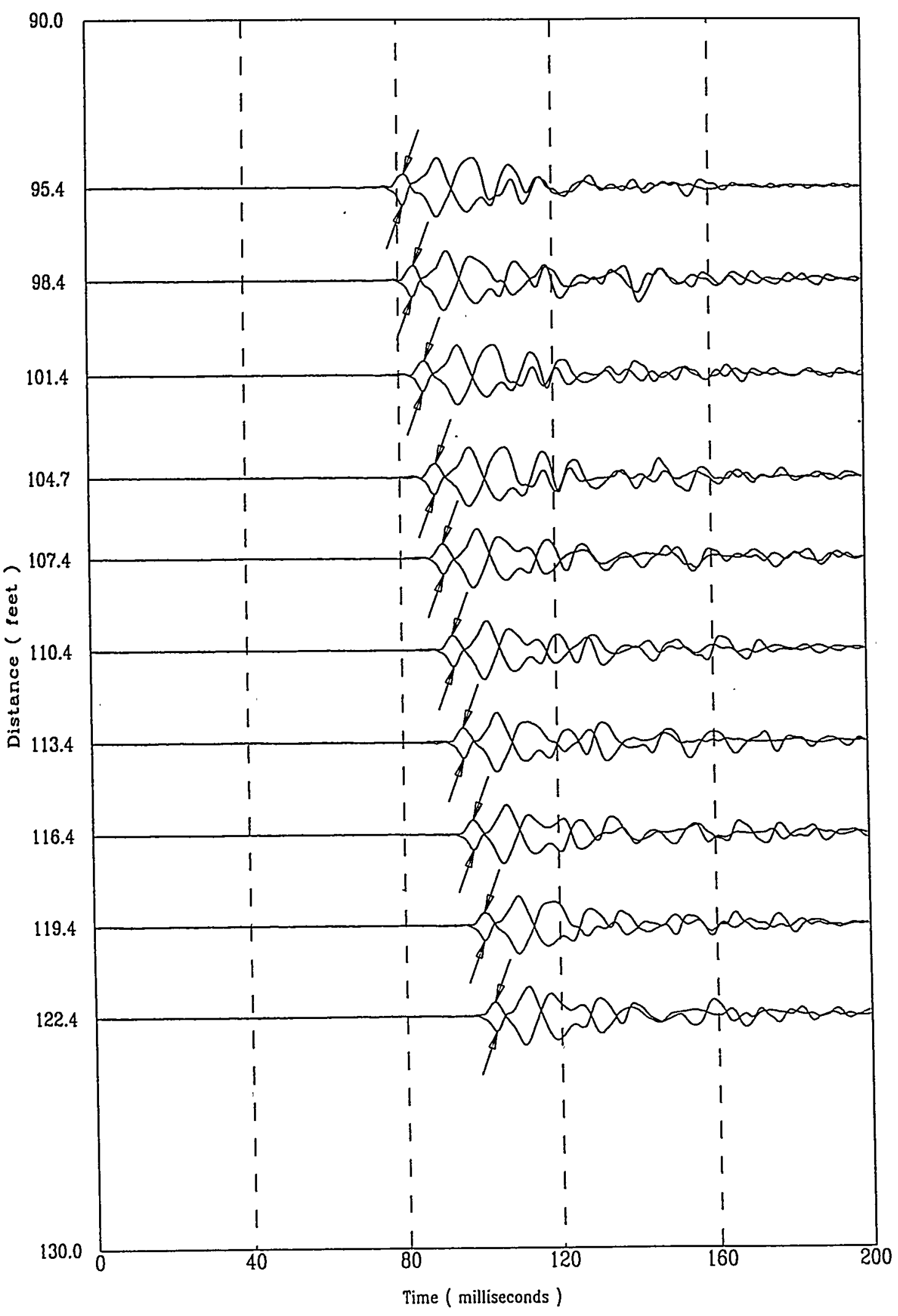


Applied Research Associates

SDFBC2

$S$ Wave

$04 / 27 / 99$

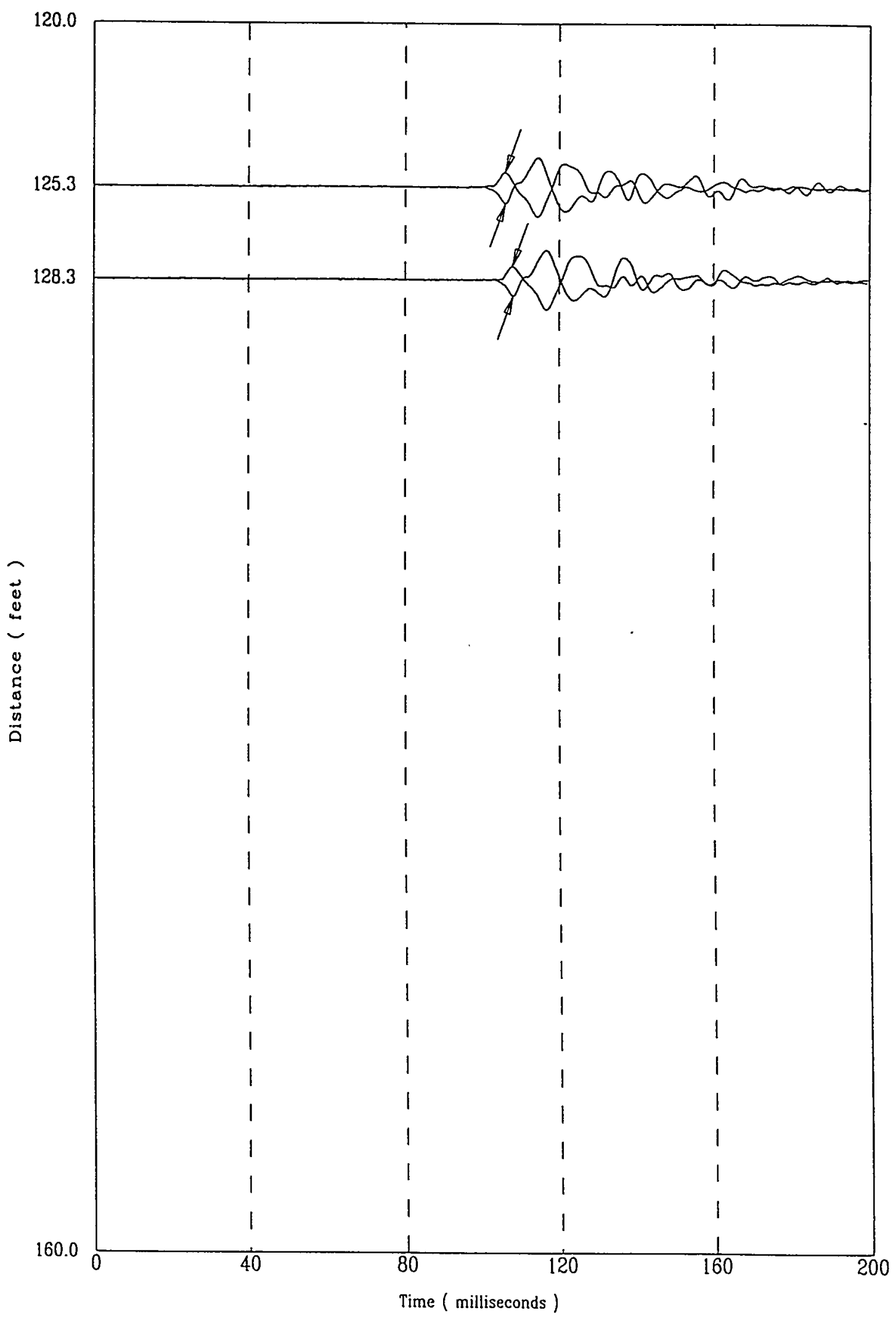




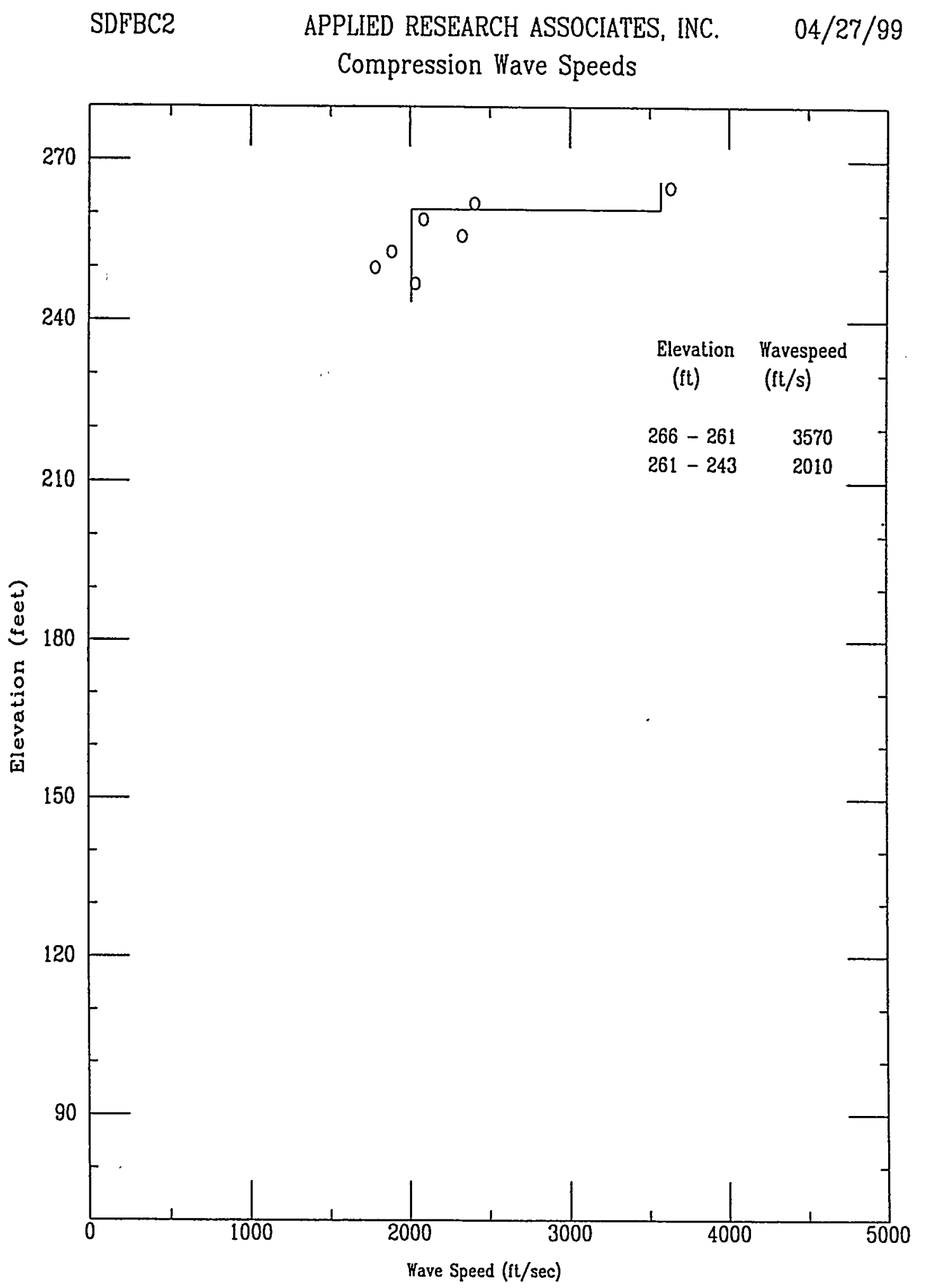

File 327a904S 


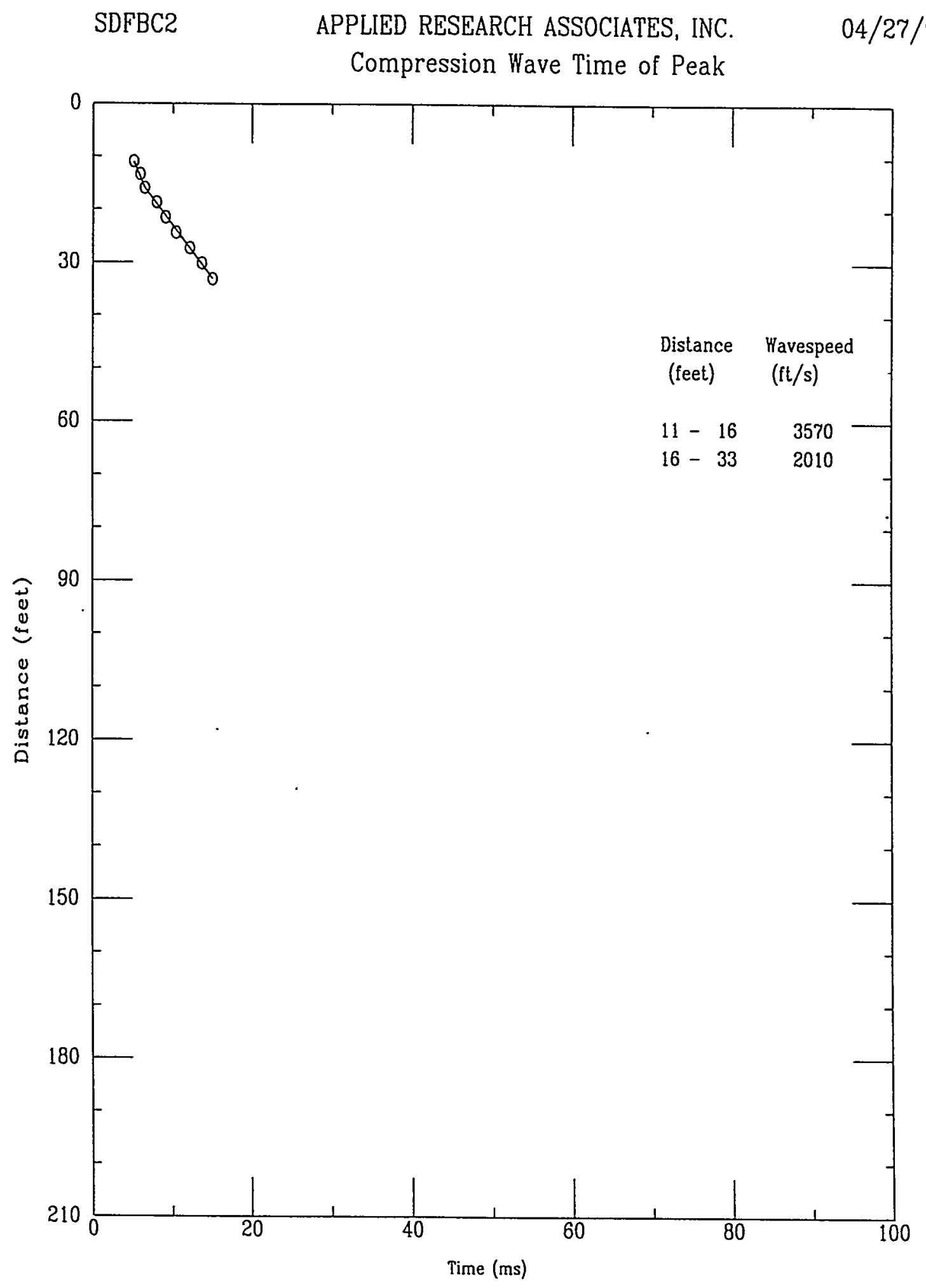

File $327 a 9045$ 


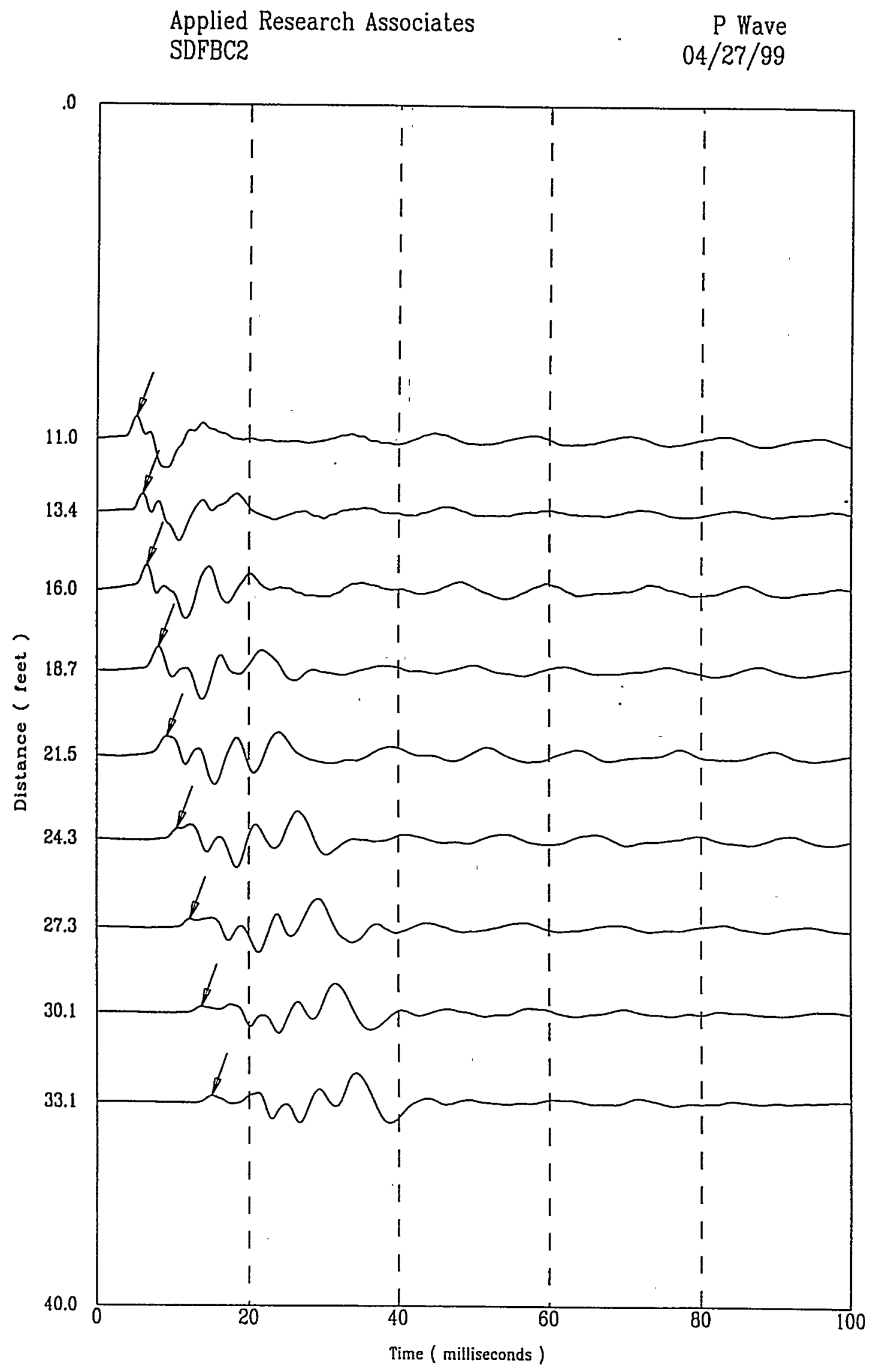


SDFBC4 APPLIED RESEARCH ASSOCIATES, INC.

$04 / 26 / 99$

North 72846.7 East $65251.9 \quad$ Elevation 278.0
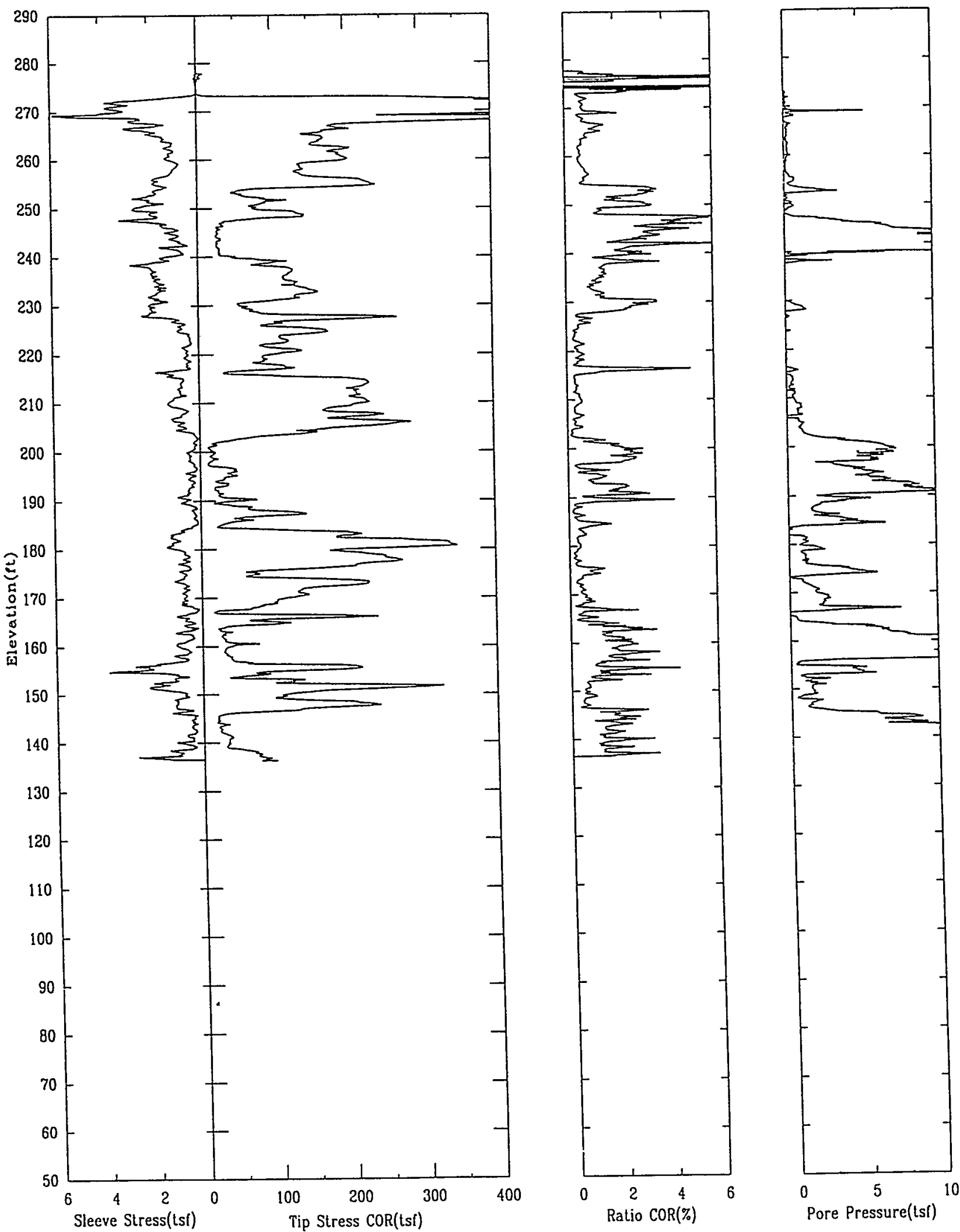
SDFBC4 APPLIED RESEARCH ASSOCIATES, INC.

North 72846.7 East 65251.9 Elevation 278.0
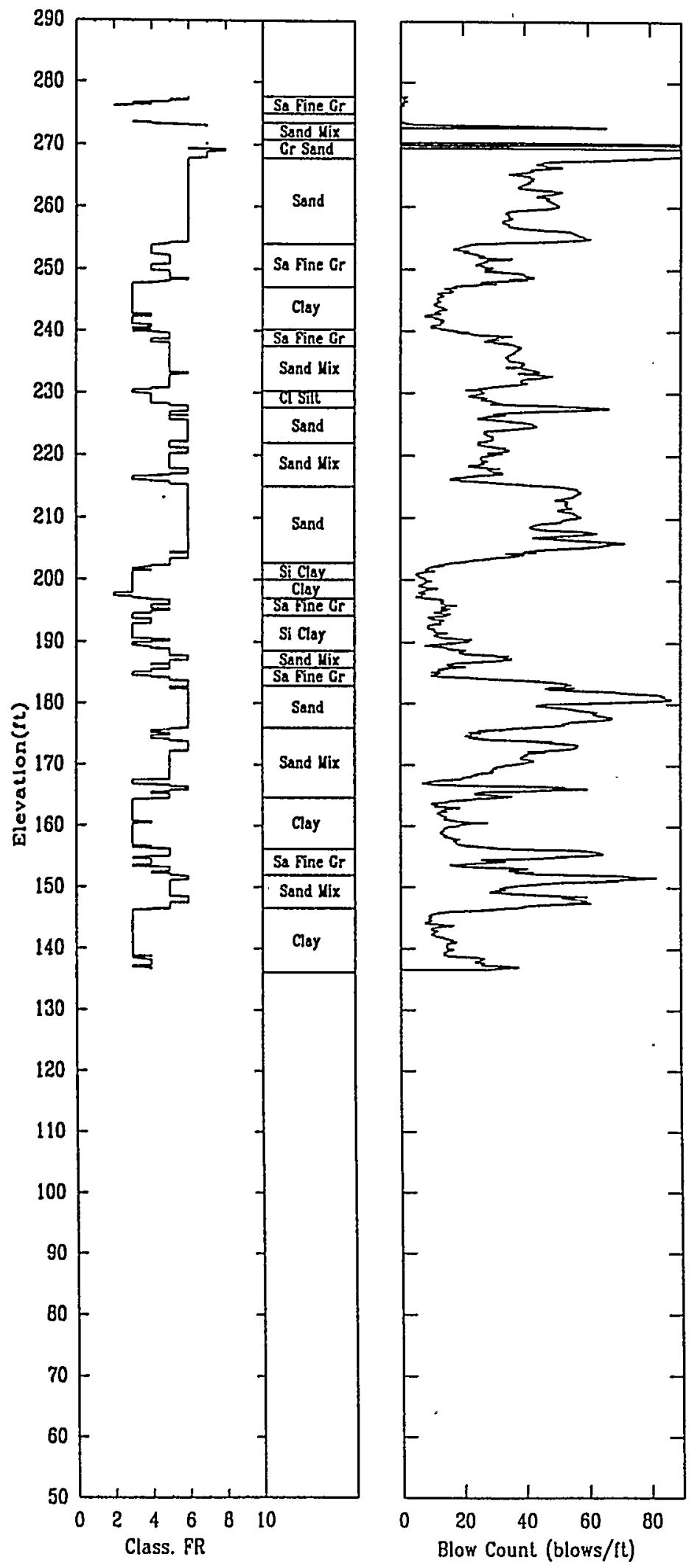

File $326 \mathrm{a} 901 . \mathrm{ECP}$ 


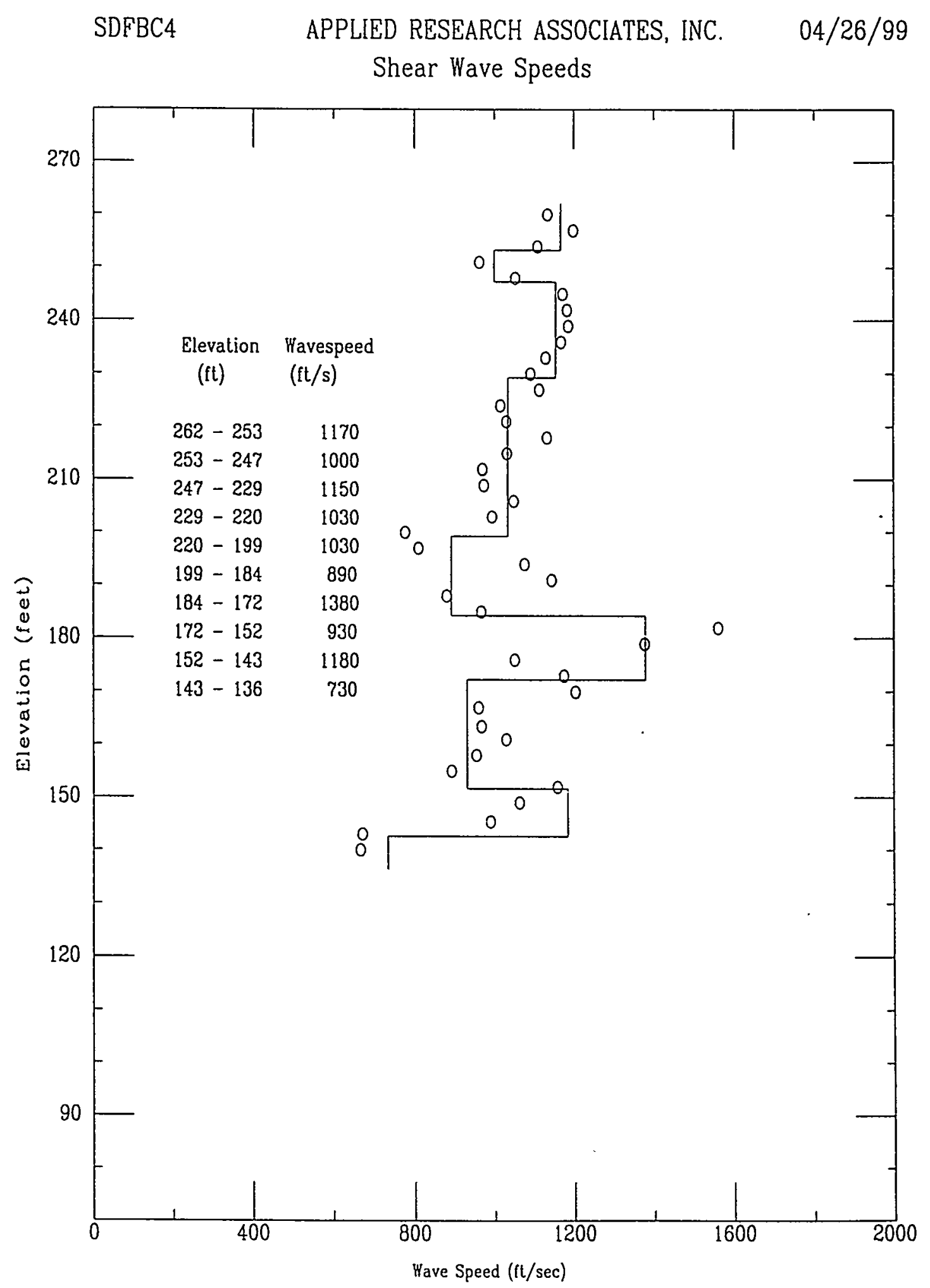

File 326a901s 


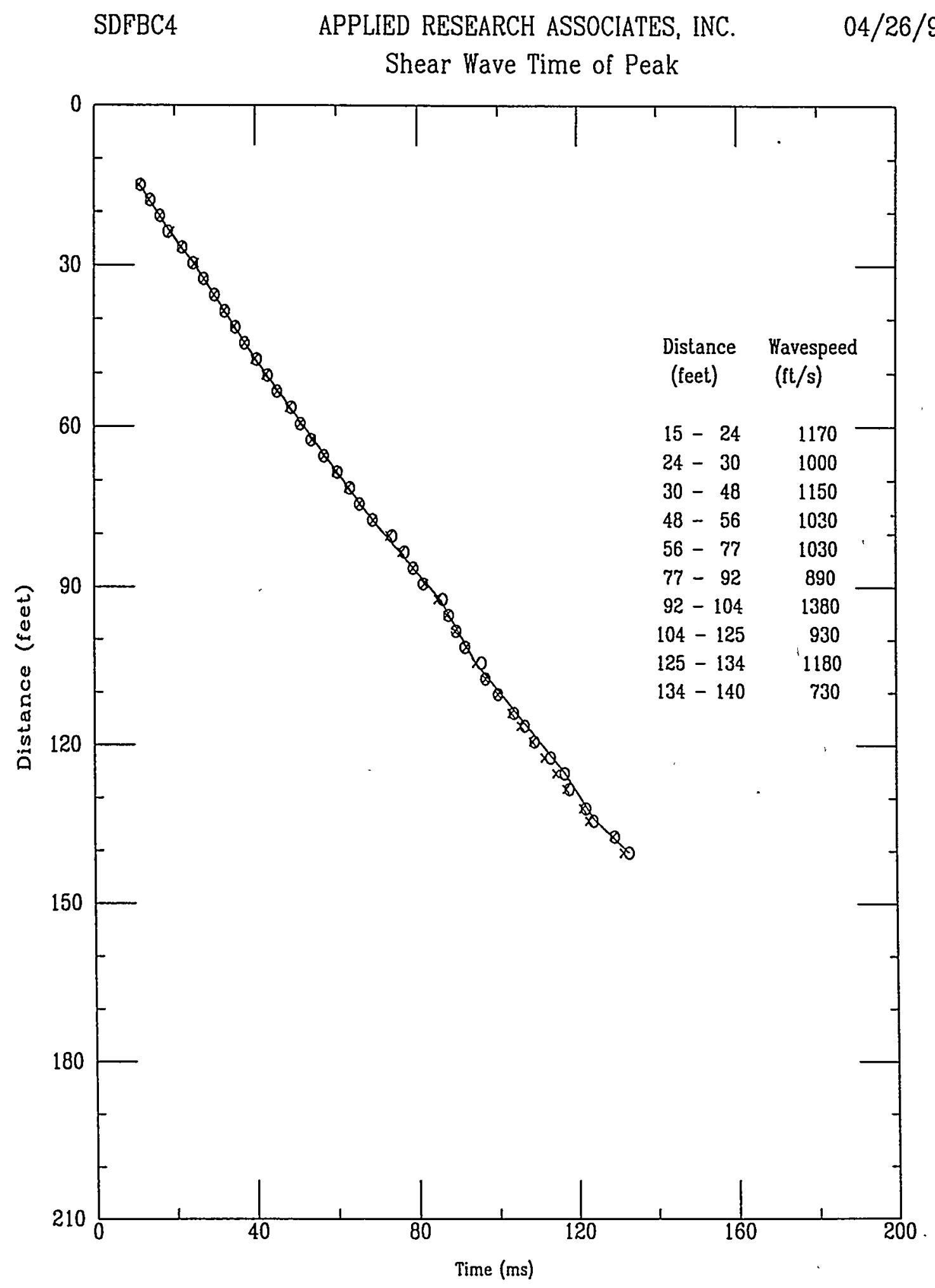

File 326a901S 


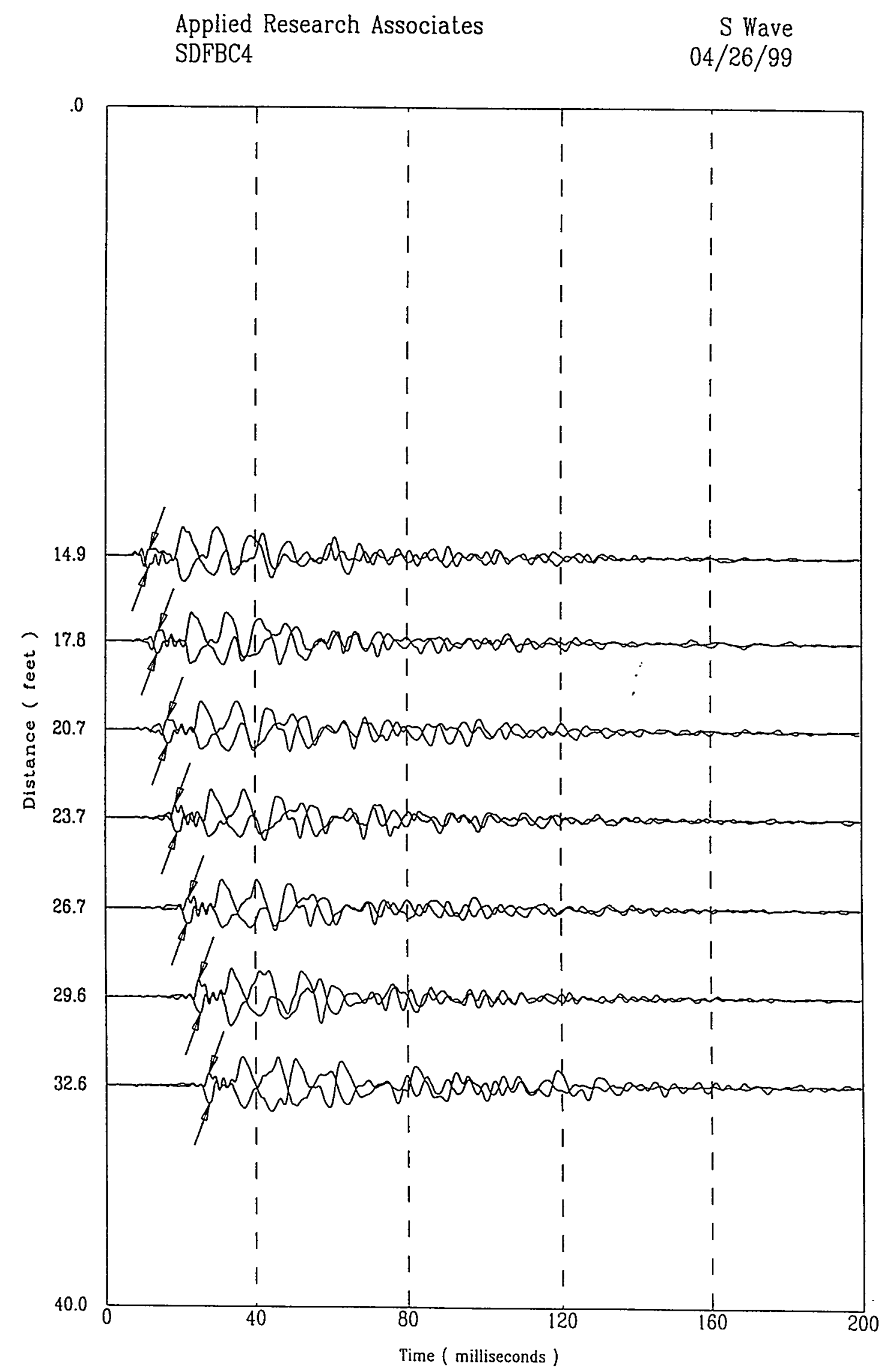


Applied Research Associates

SDFBC4

S Wave

04/26/99

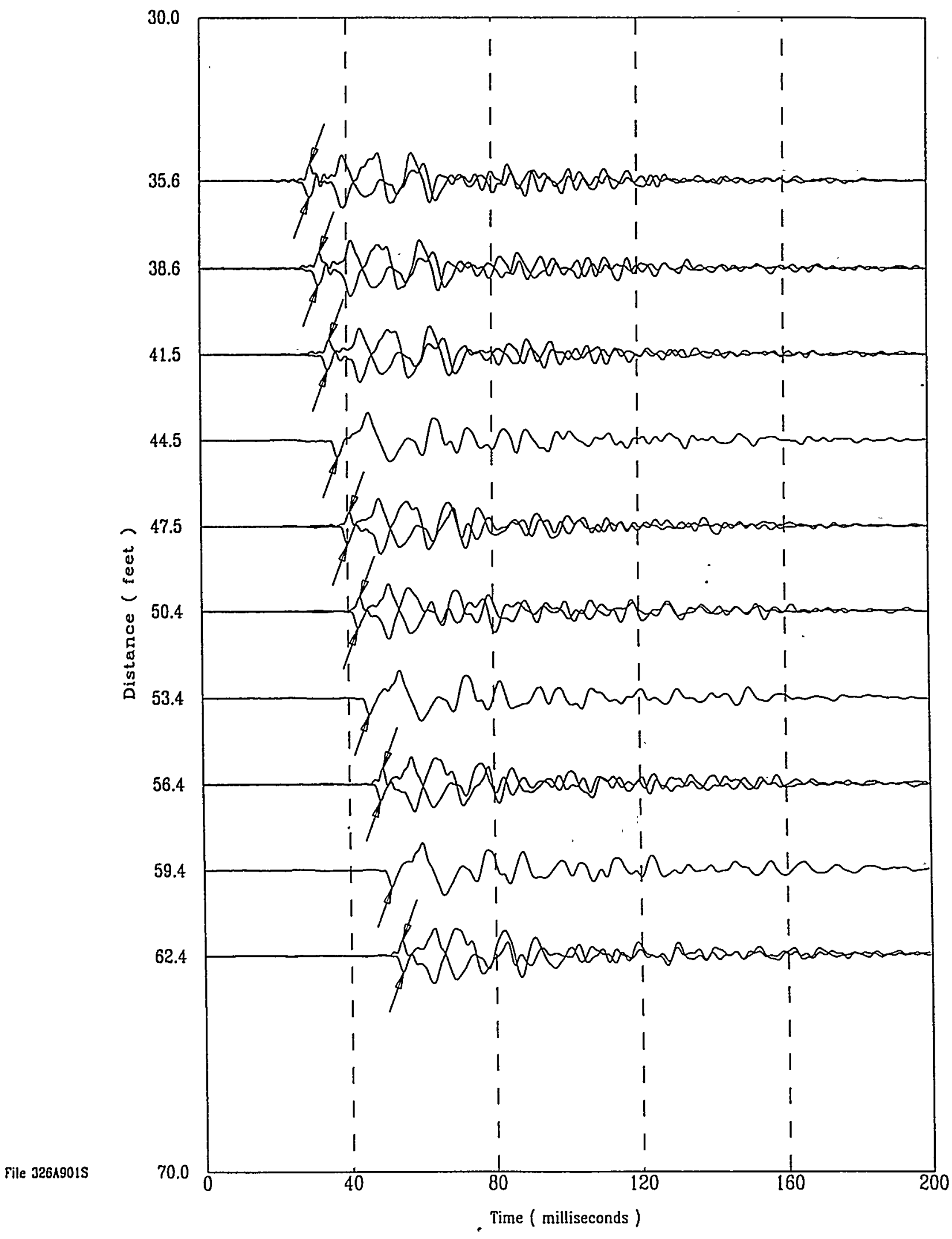




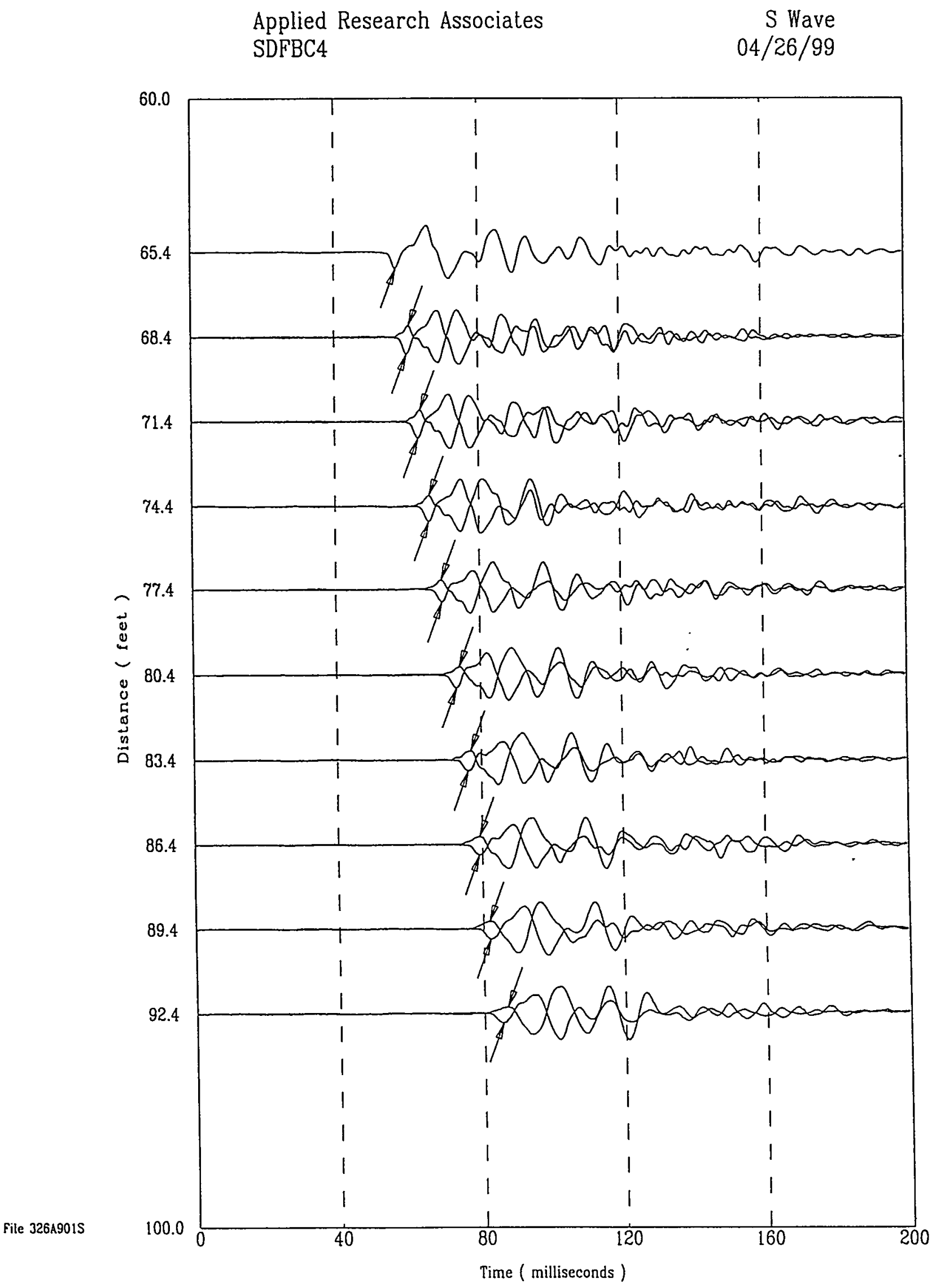


Applied Research Associates

SDFBC4

S Wave

$04 / 26 / 99$

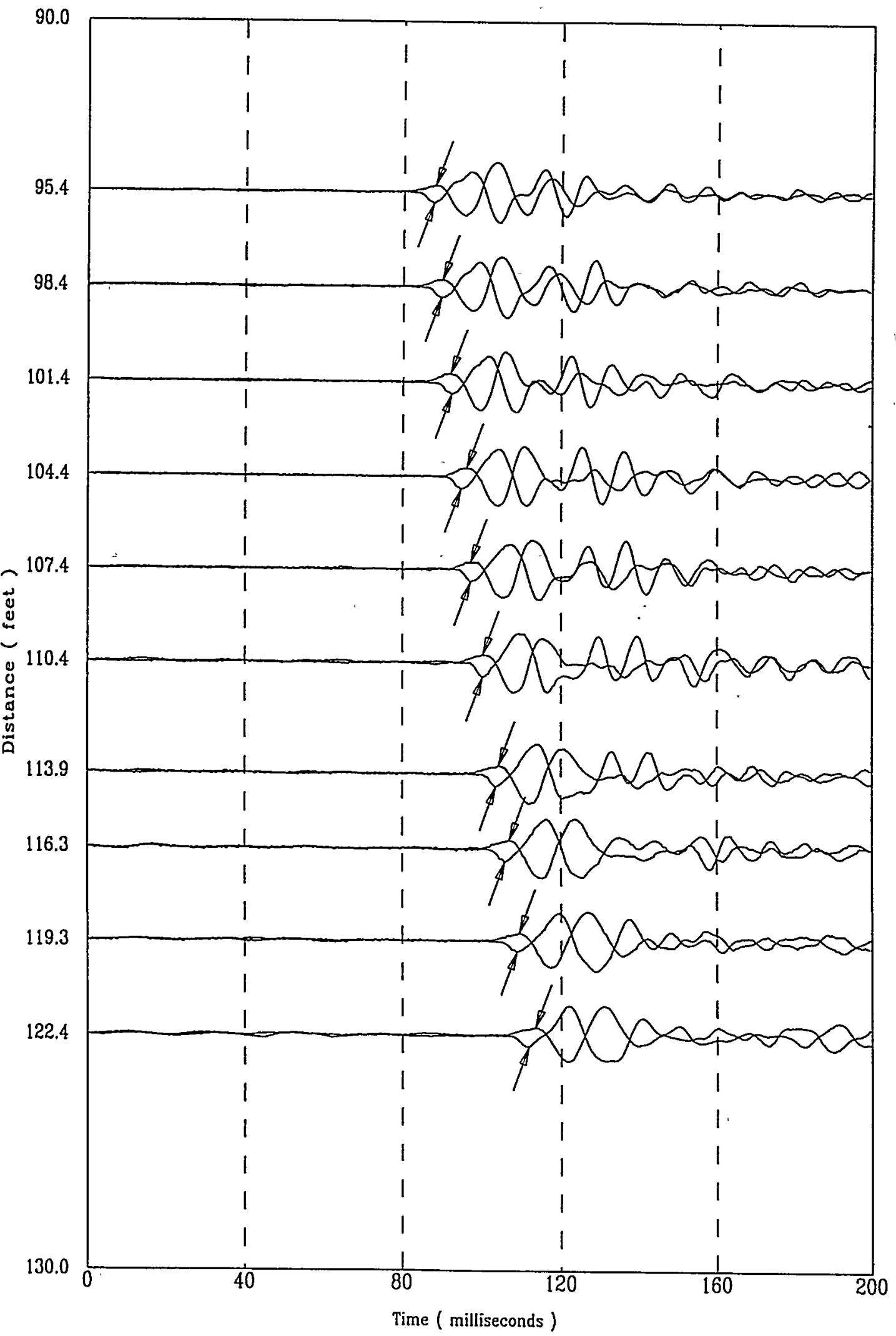


Applied Research Associates

SDFBC4

S Wave

$04 / 26 / 99$

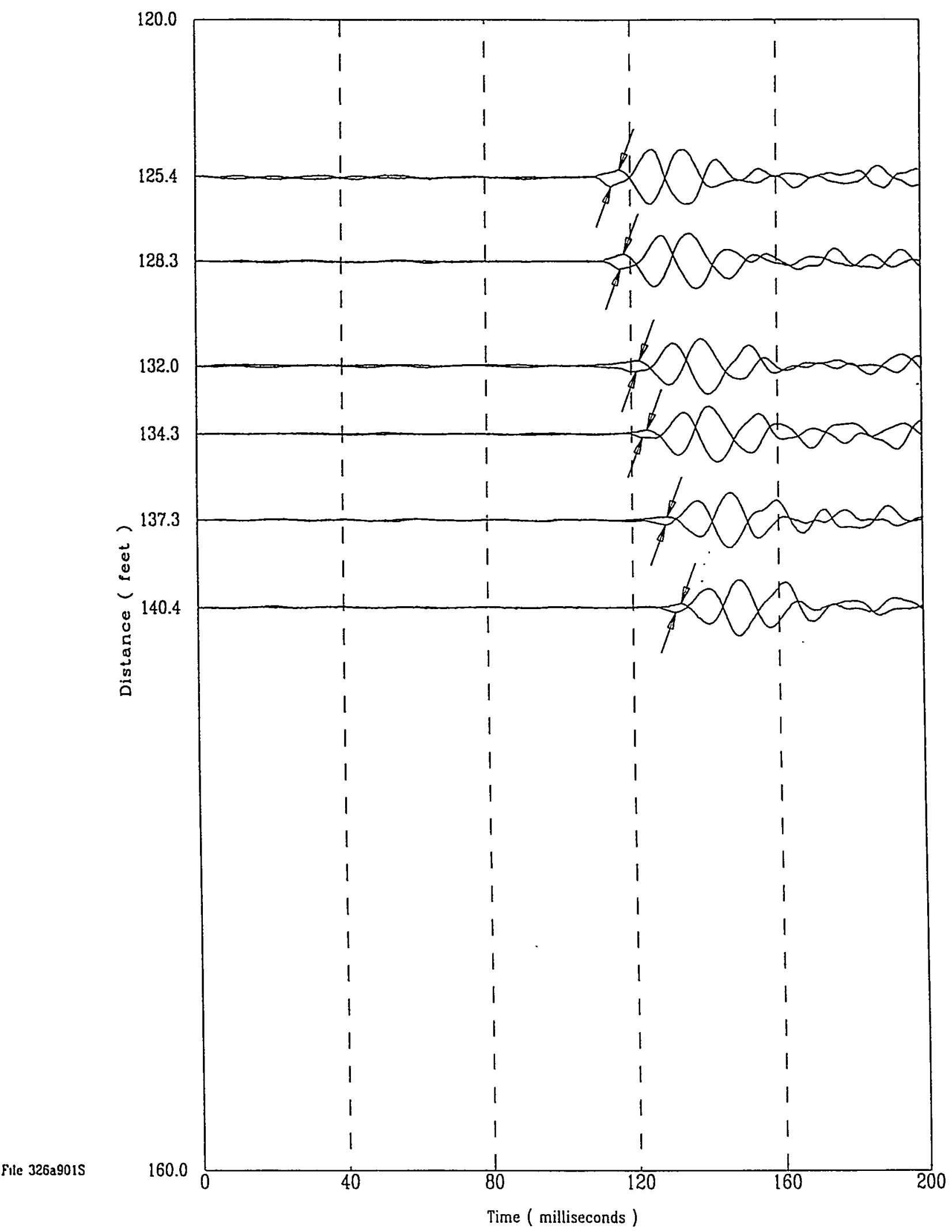




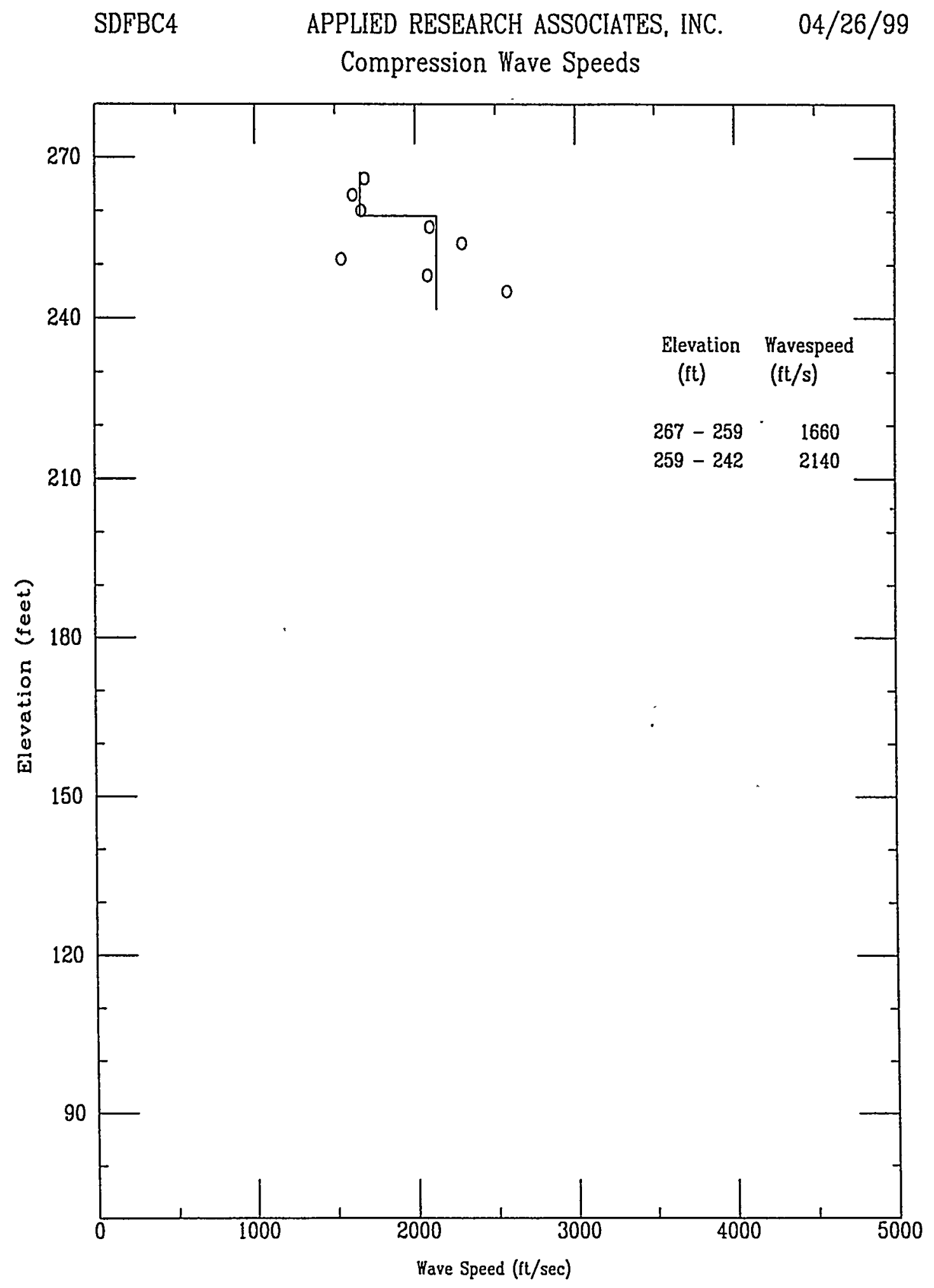

File $326 a 90$ is 


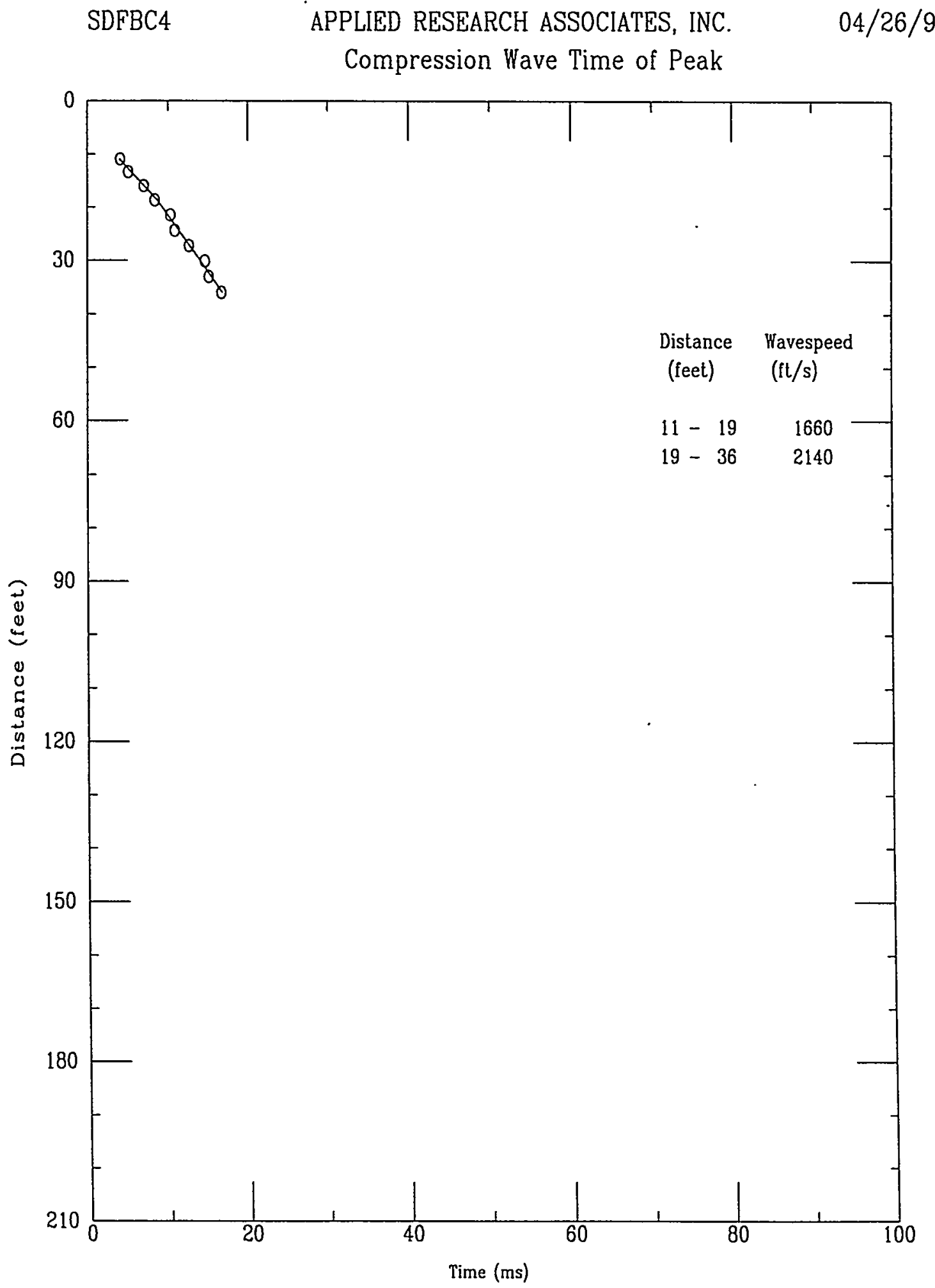

File $326 a 901 S$ 
- Applied Research Associates SDFBC4

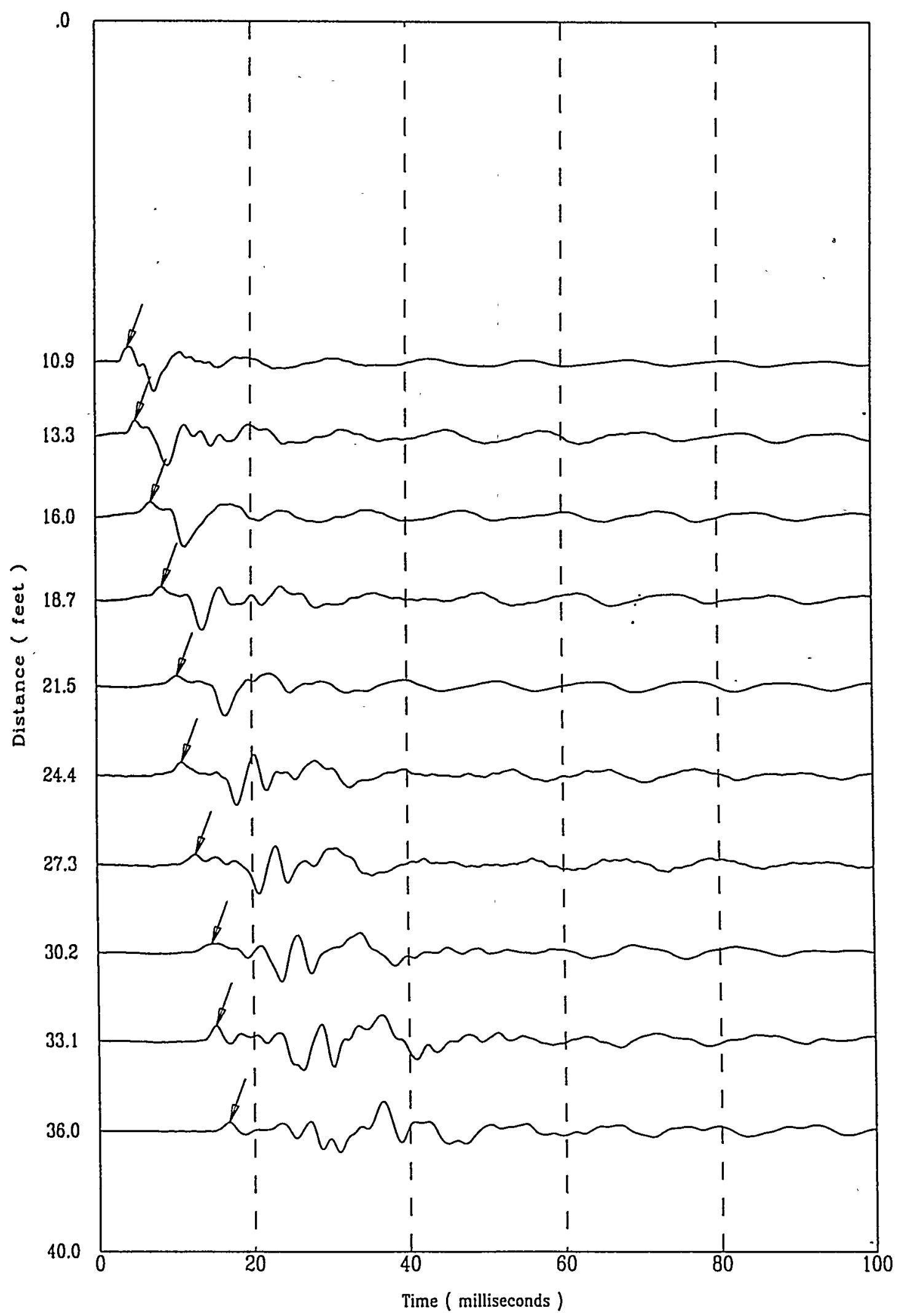


SDFBC7 APPLIED RESEARCH ASSOCIATES, INC. 04/27/99 North 72703.0 East 65393.4 Elevation 274.0
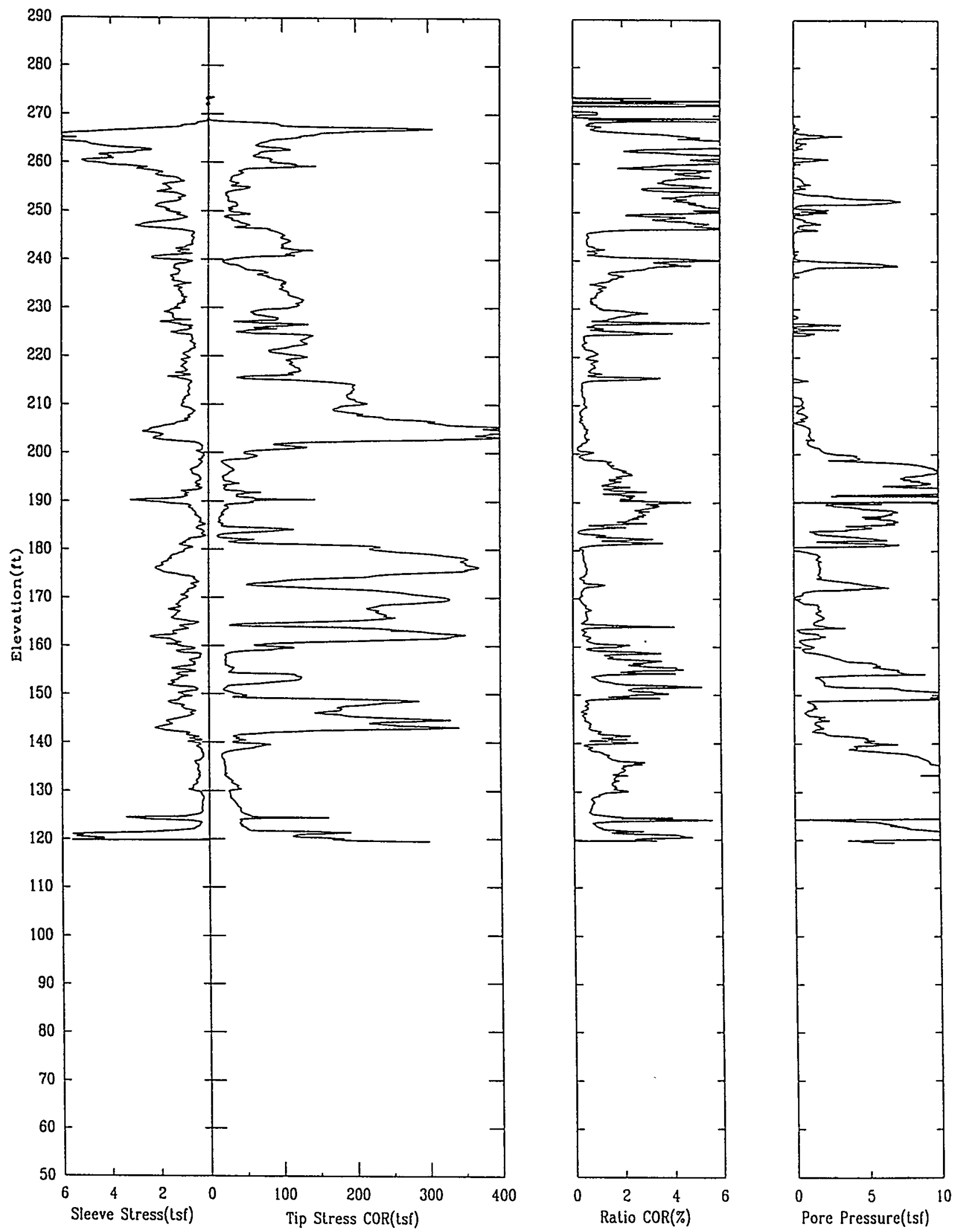
SDFBC7 APPLIED RESEARCH ASSOCIATES, INC.

North 72703.0 East 65393.4 Elevation 274.0
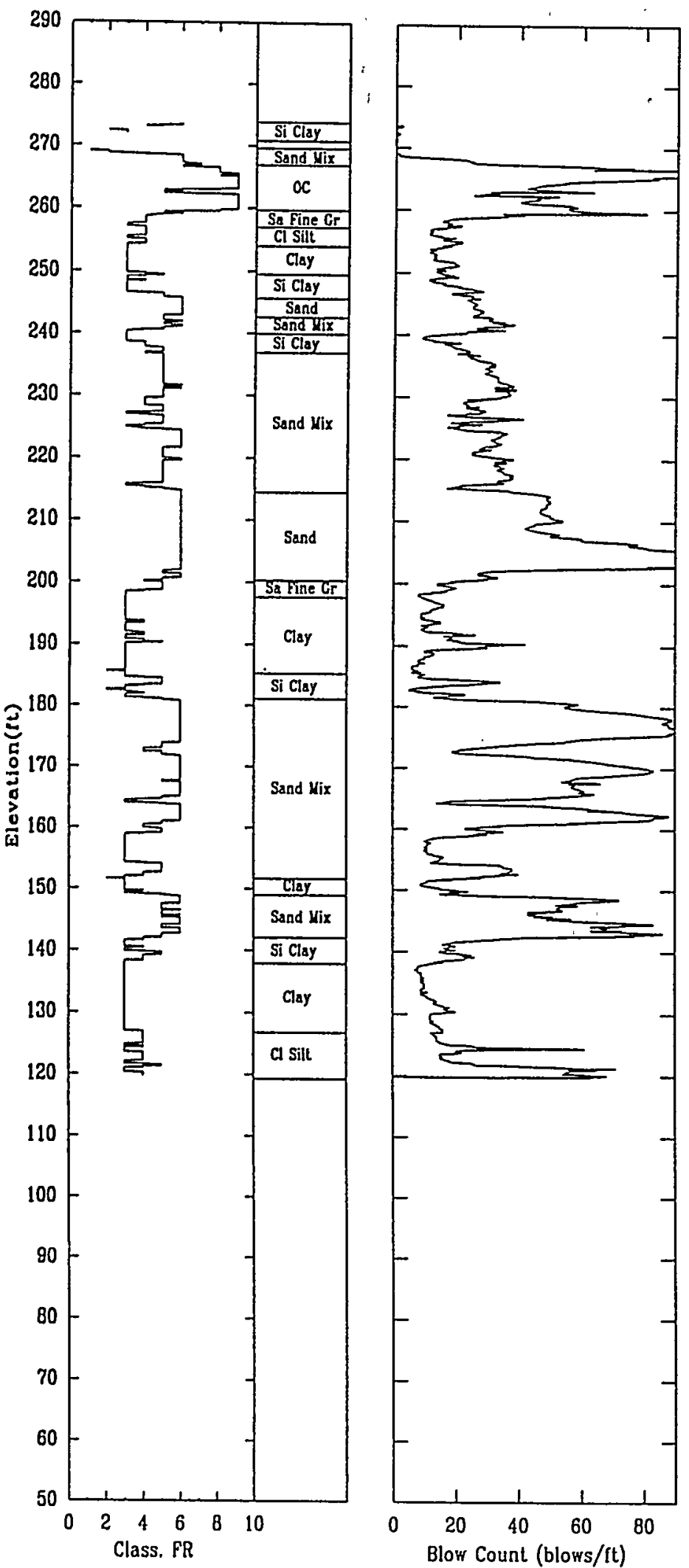


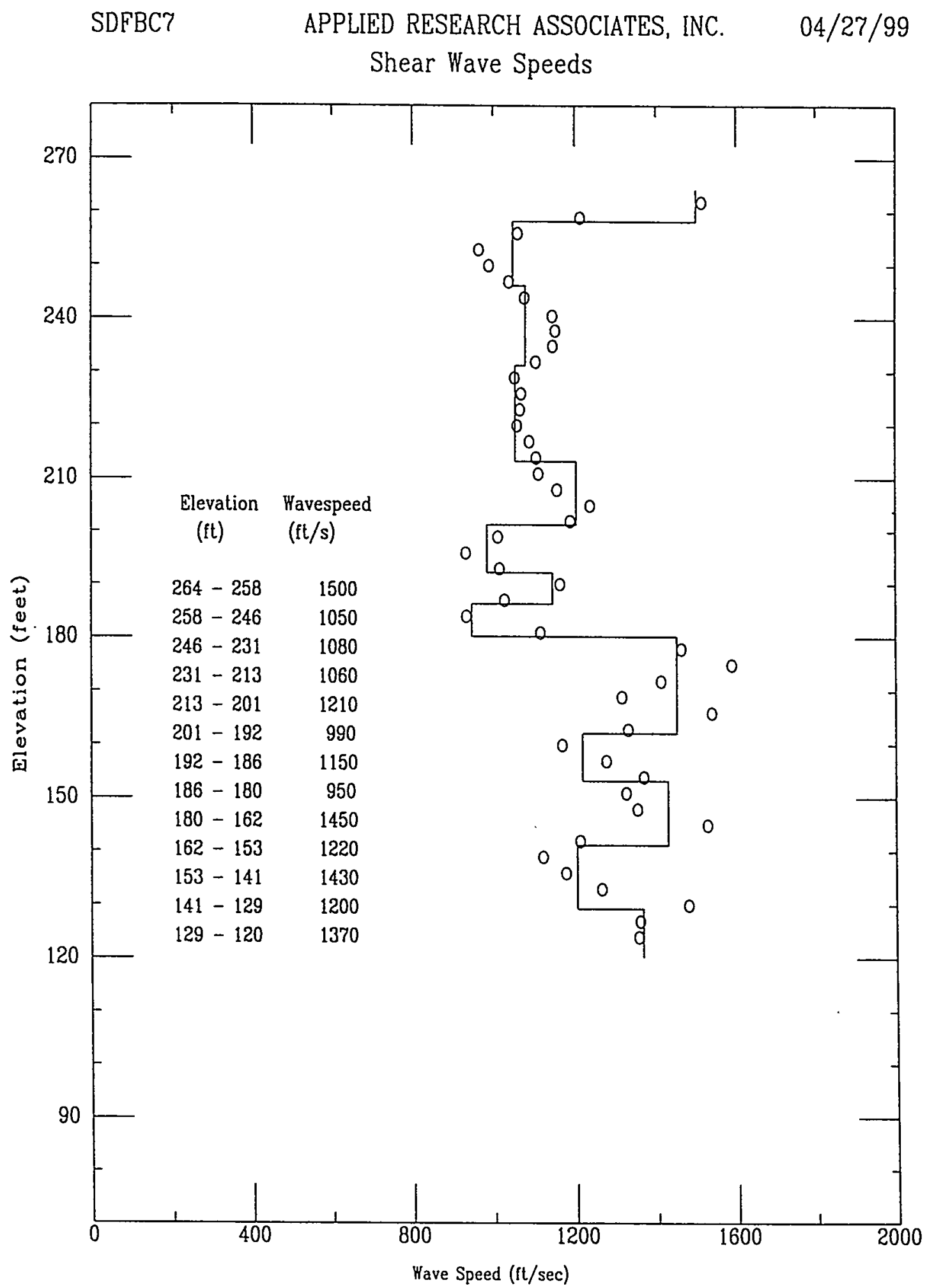

File 327A9015 


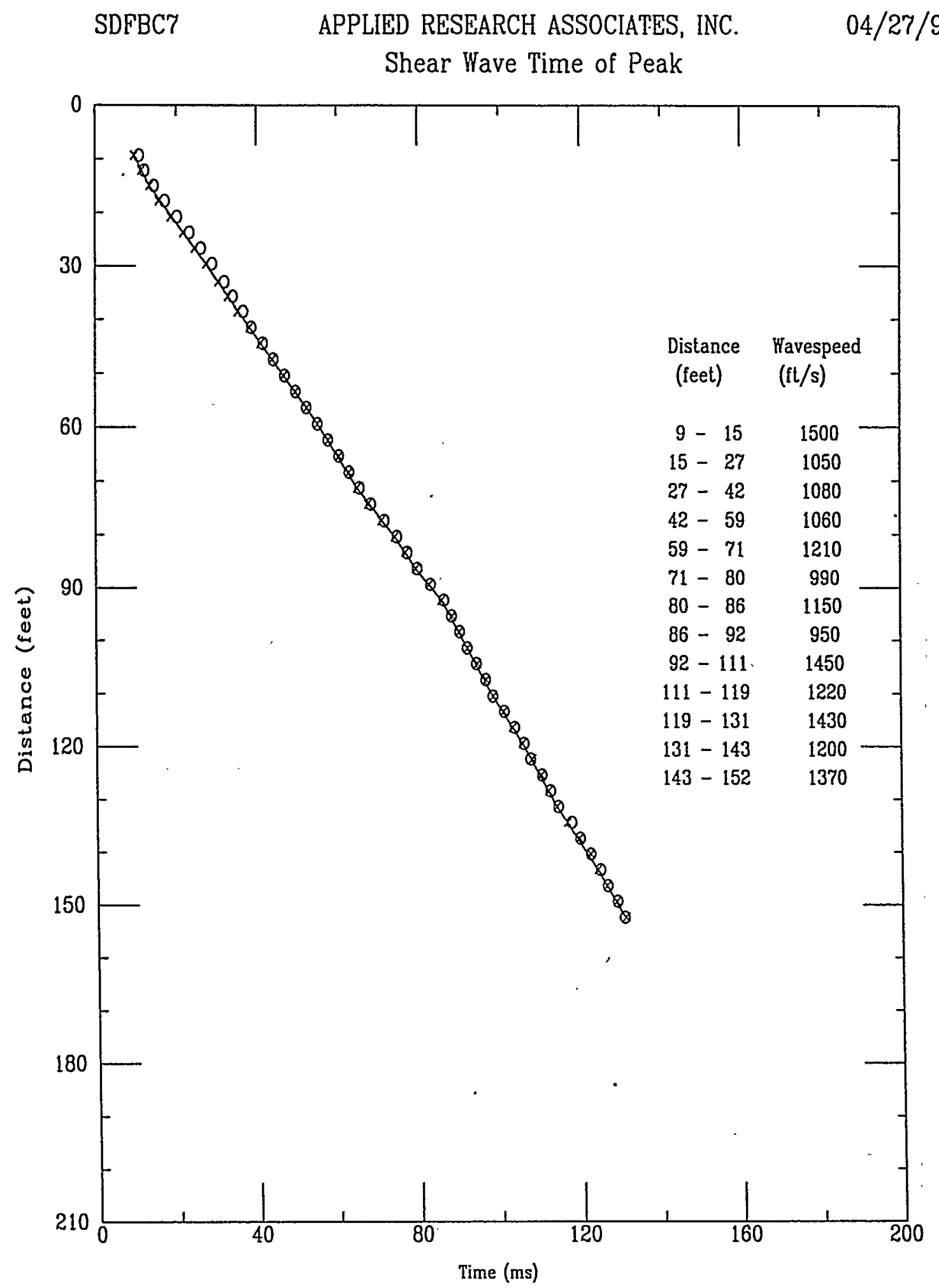

File 327A901S 
Applied Research Associates SDFBC7

S Wave
$04 / 27 / 99$

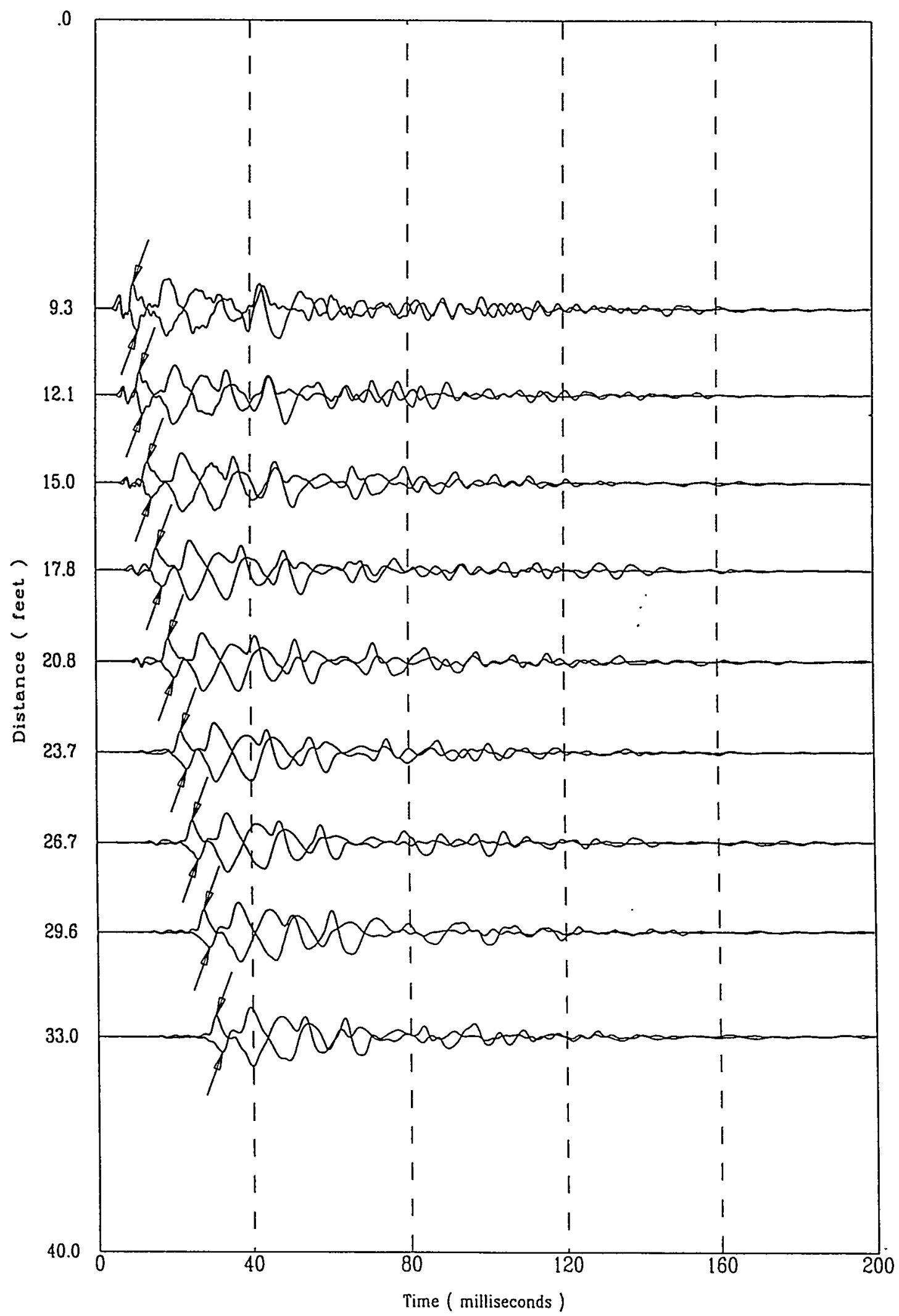


Applied Research Associates SDFBC7

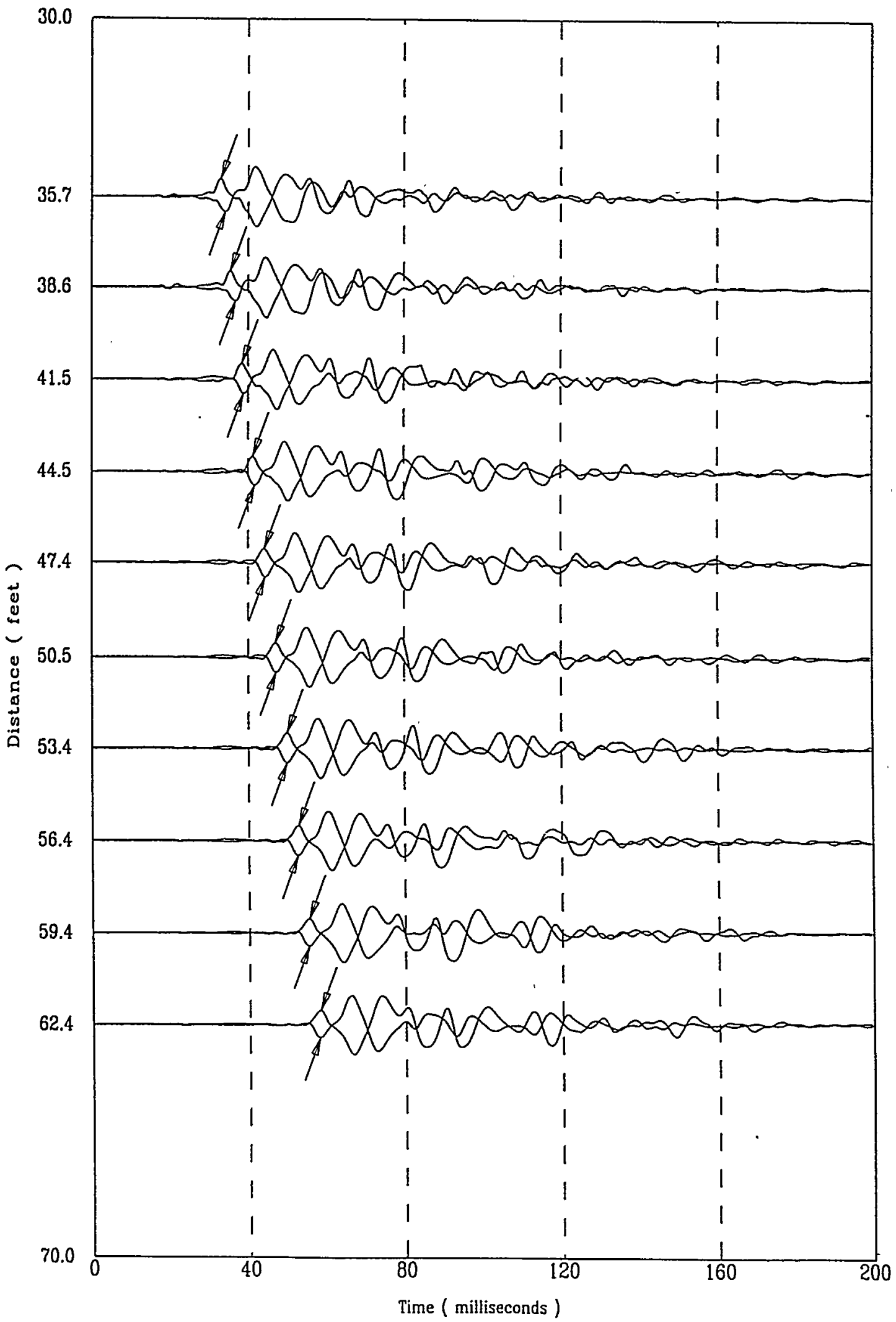


Applied Research Associates

SDFBC7

$S$ Wave

$04 / 27 / 99$

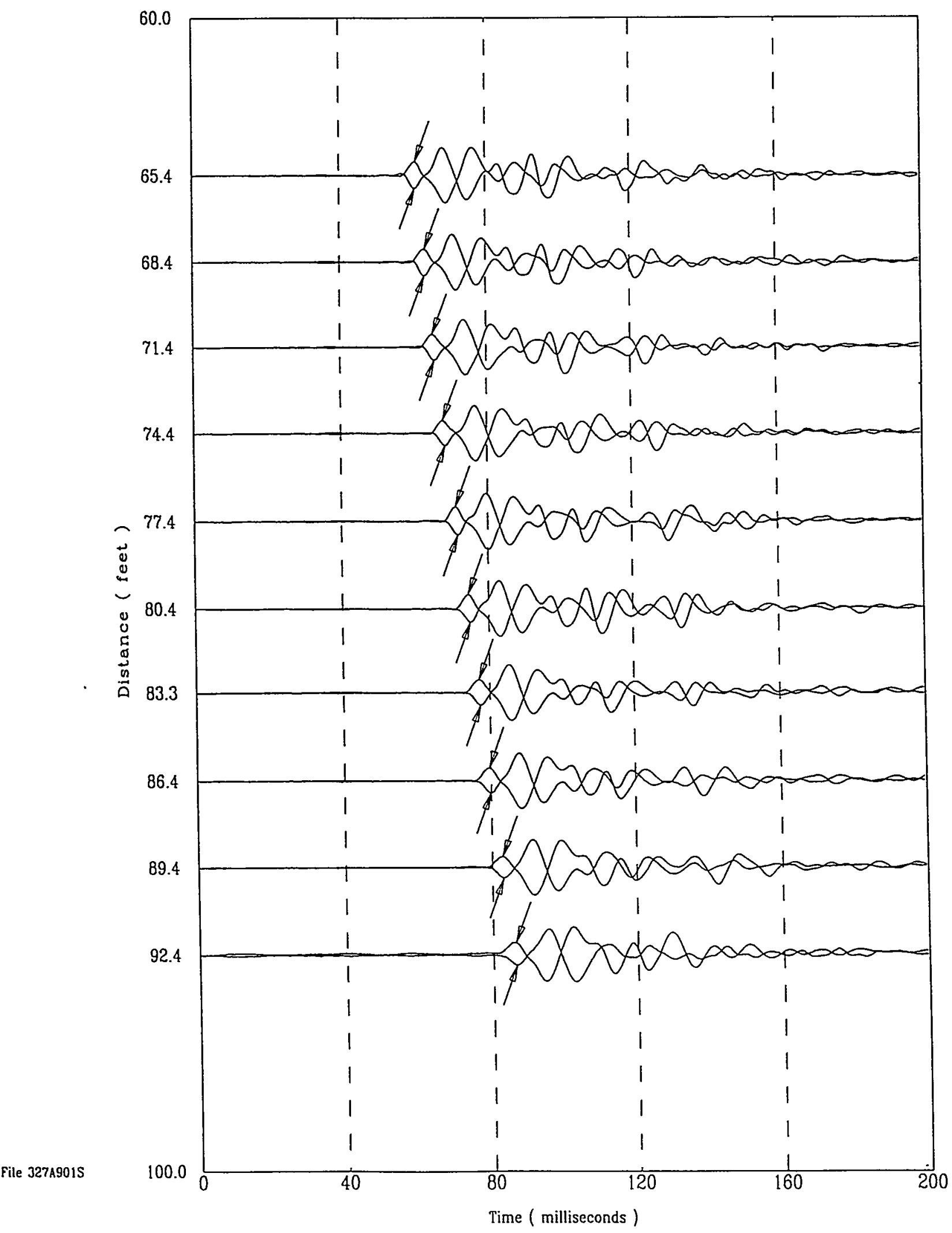


Applied Research Associates

SDFBC7

S Wave

$04 / 27 / 99$

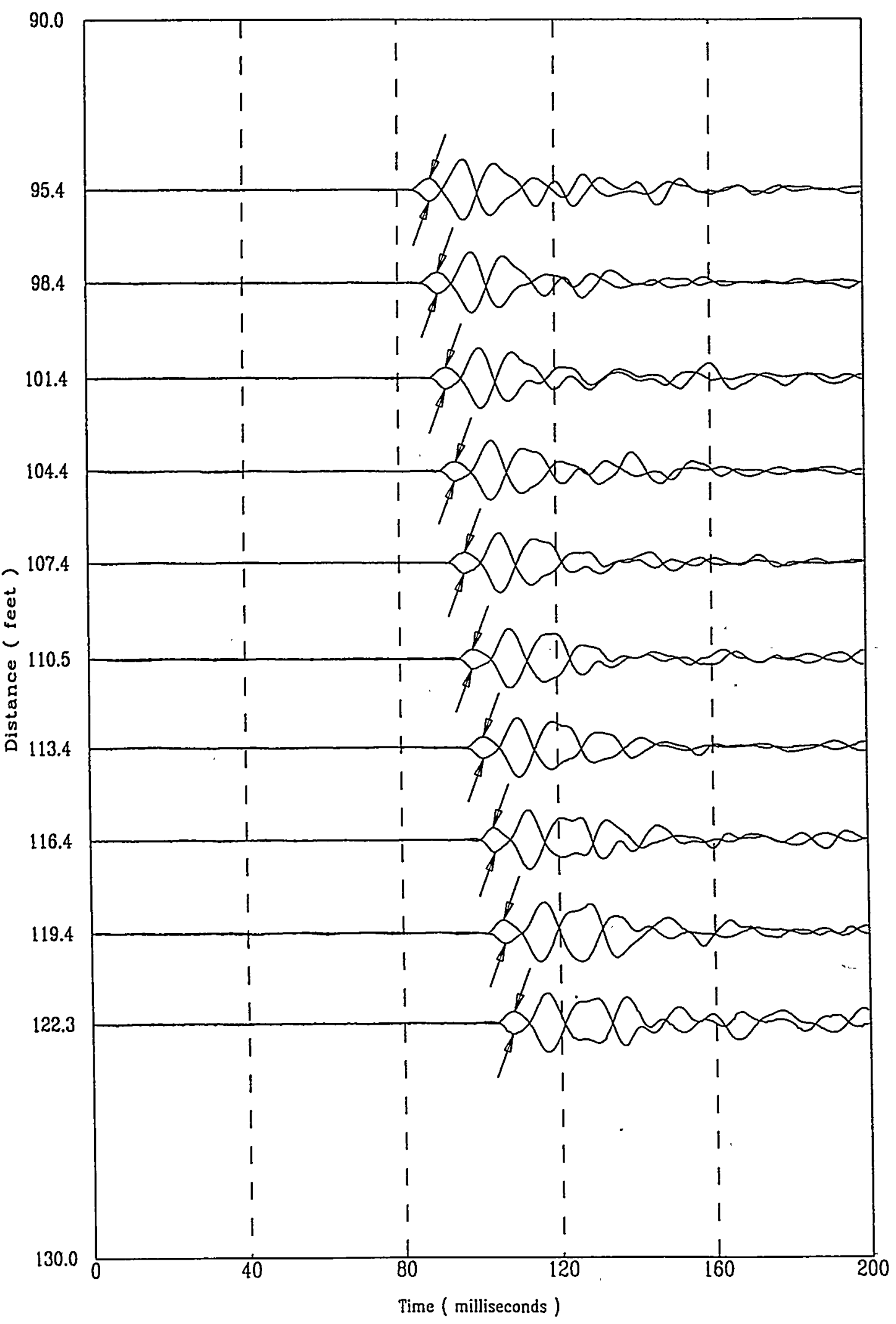




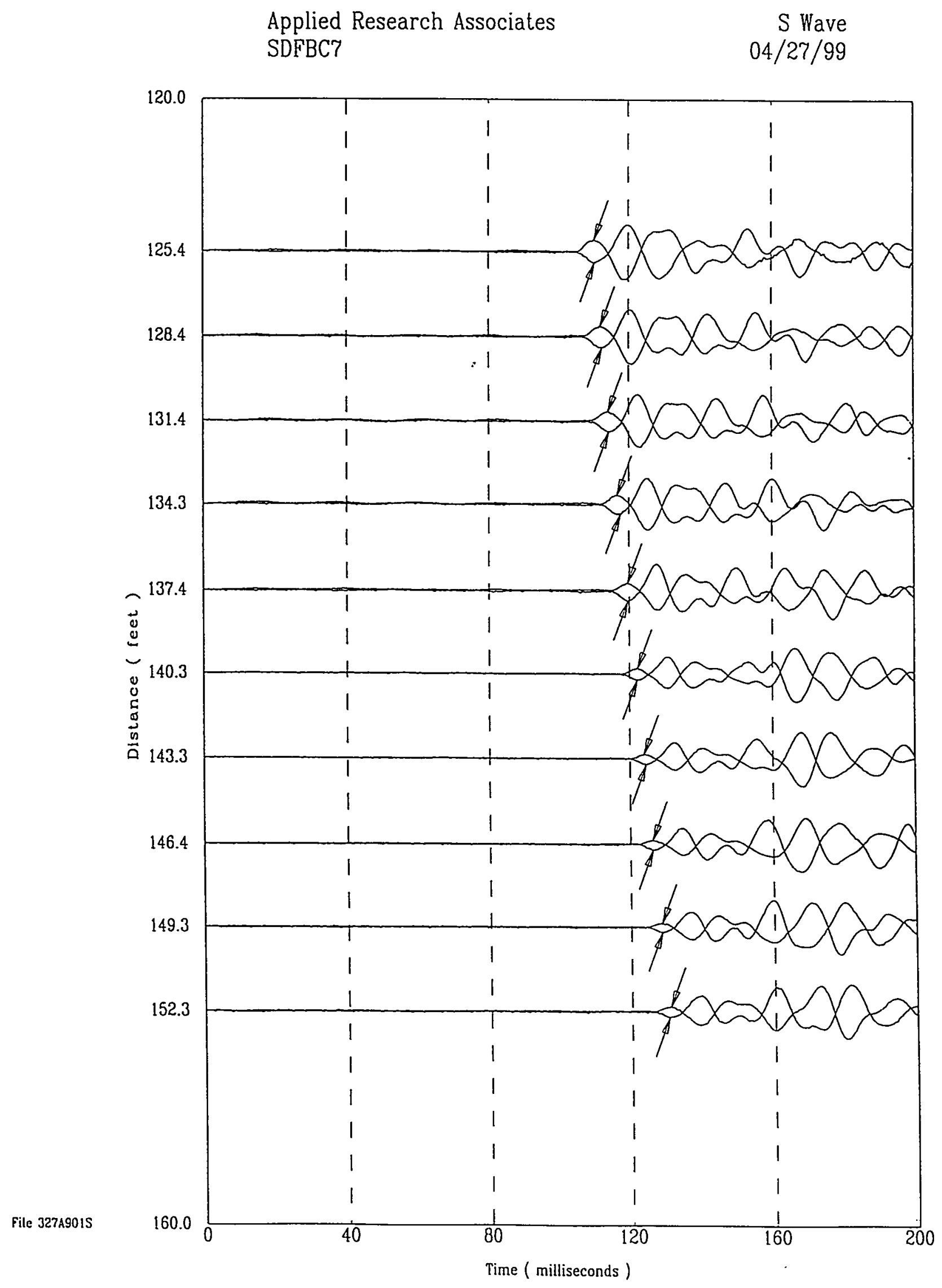




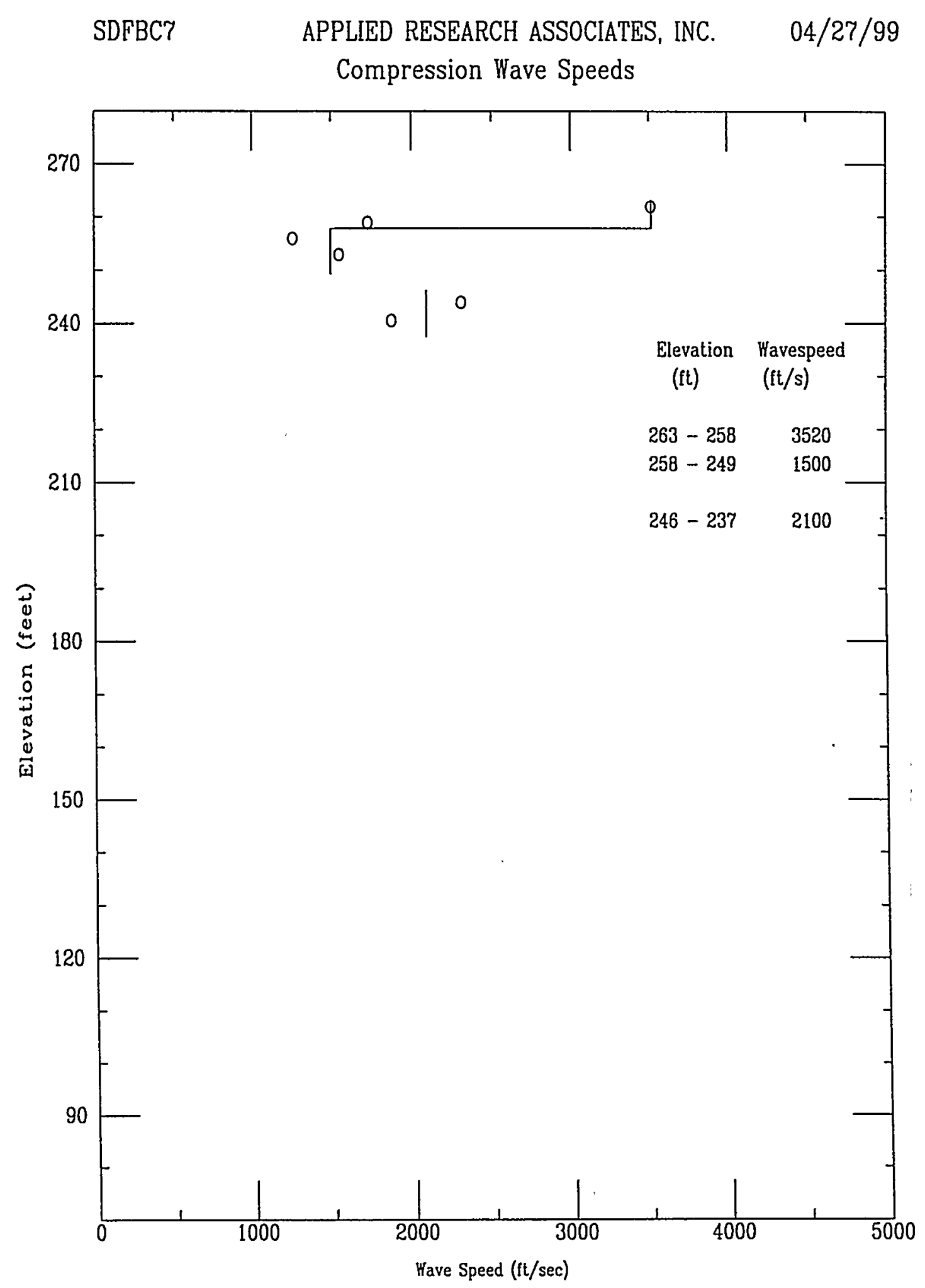

File 327a901S 


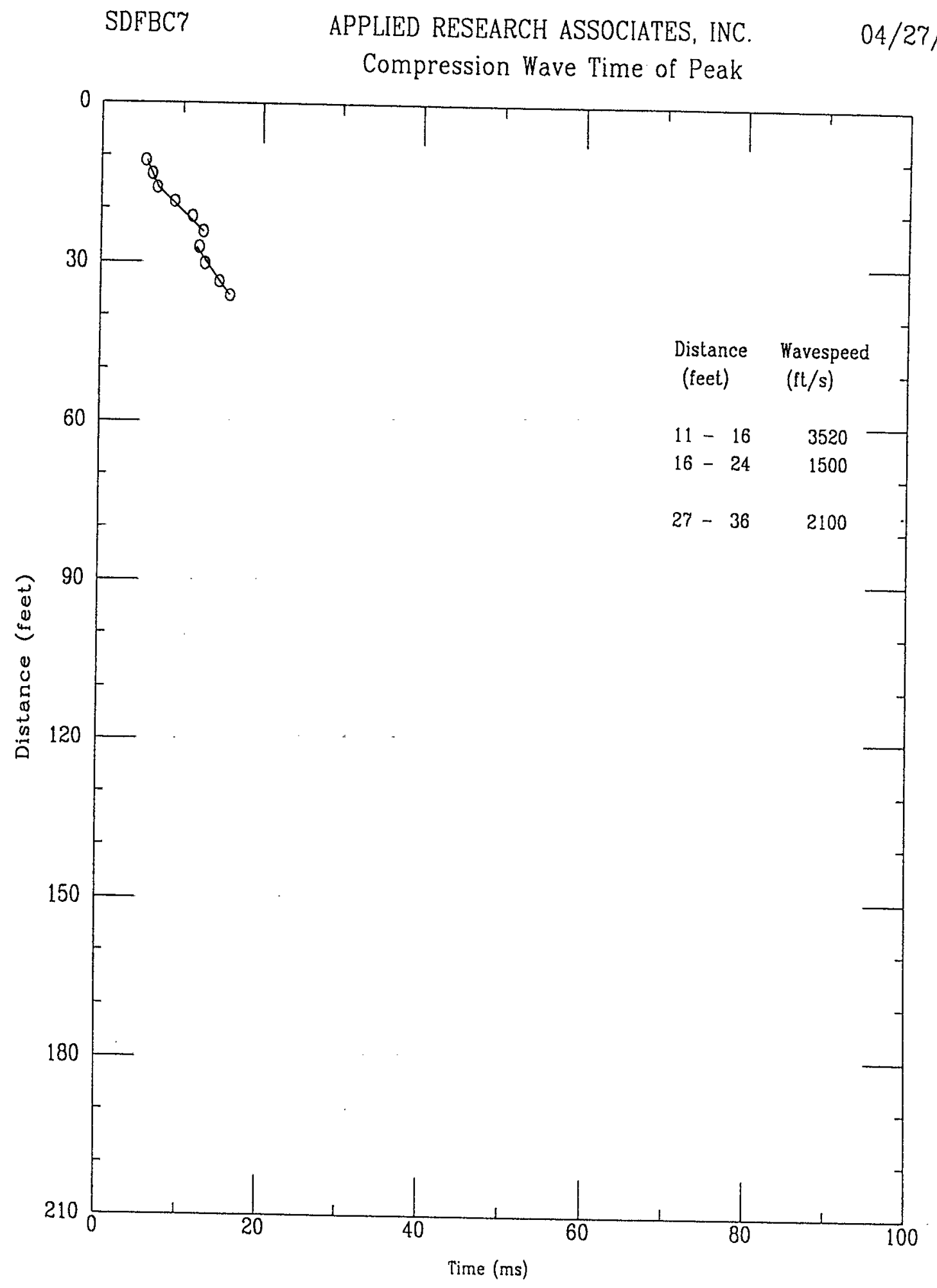


Applied Research Associates

SDFBC?

$P$ Wave

$04 / 27 / 99$

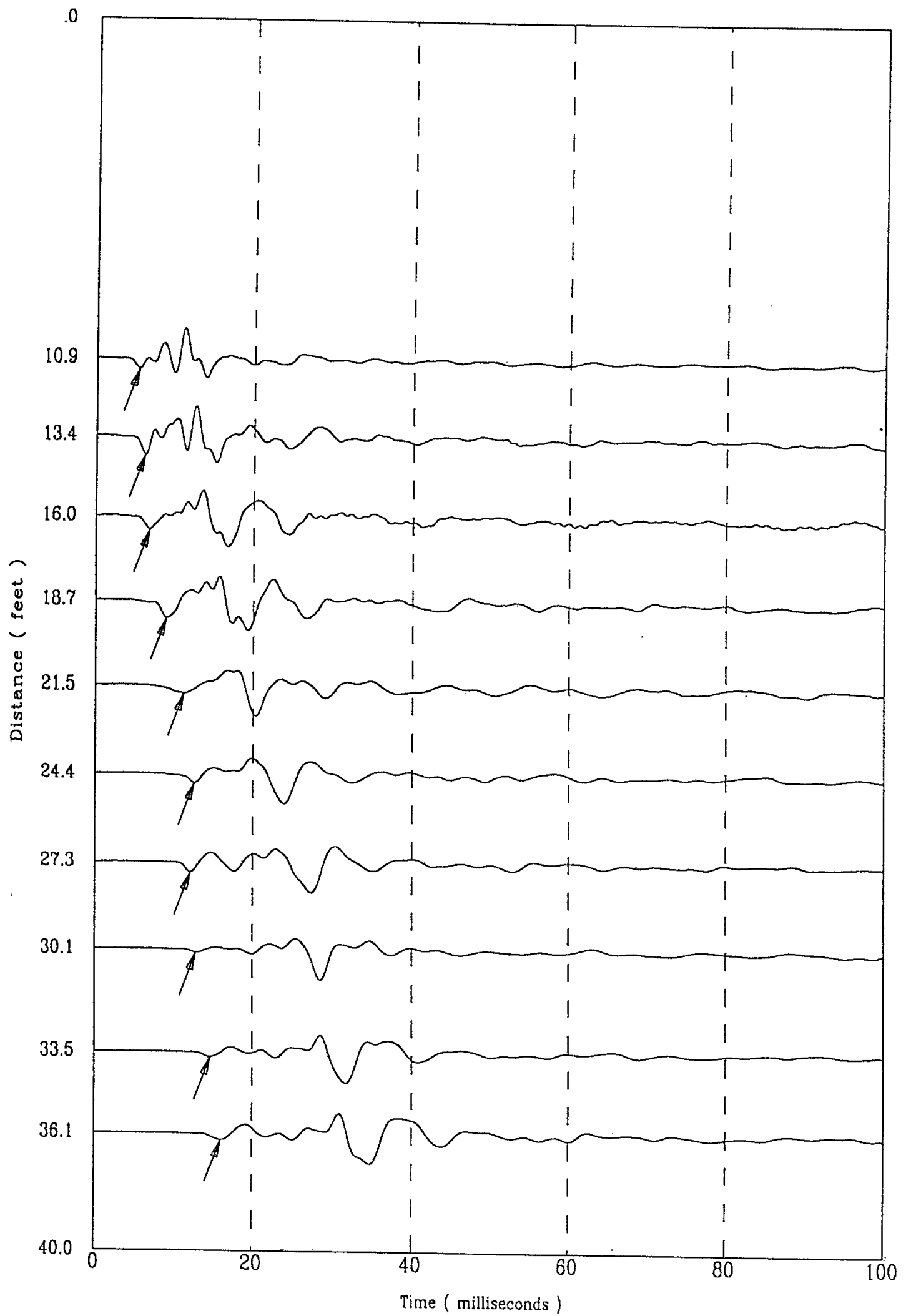


North 72751.5 East $65251.9 \quad$ Elevation 277.0
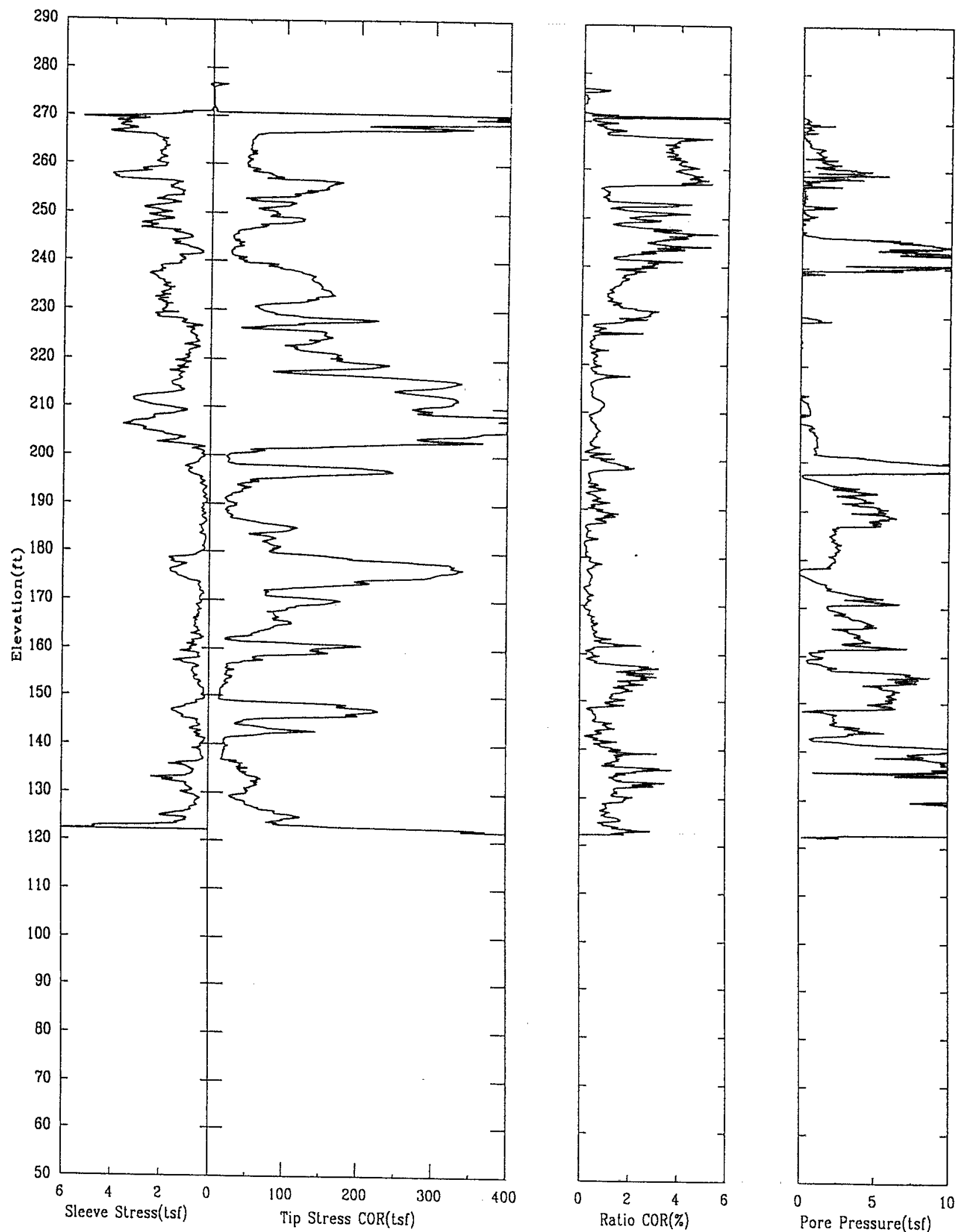
North 72751.5 East 65251.9 Elevation 277.0
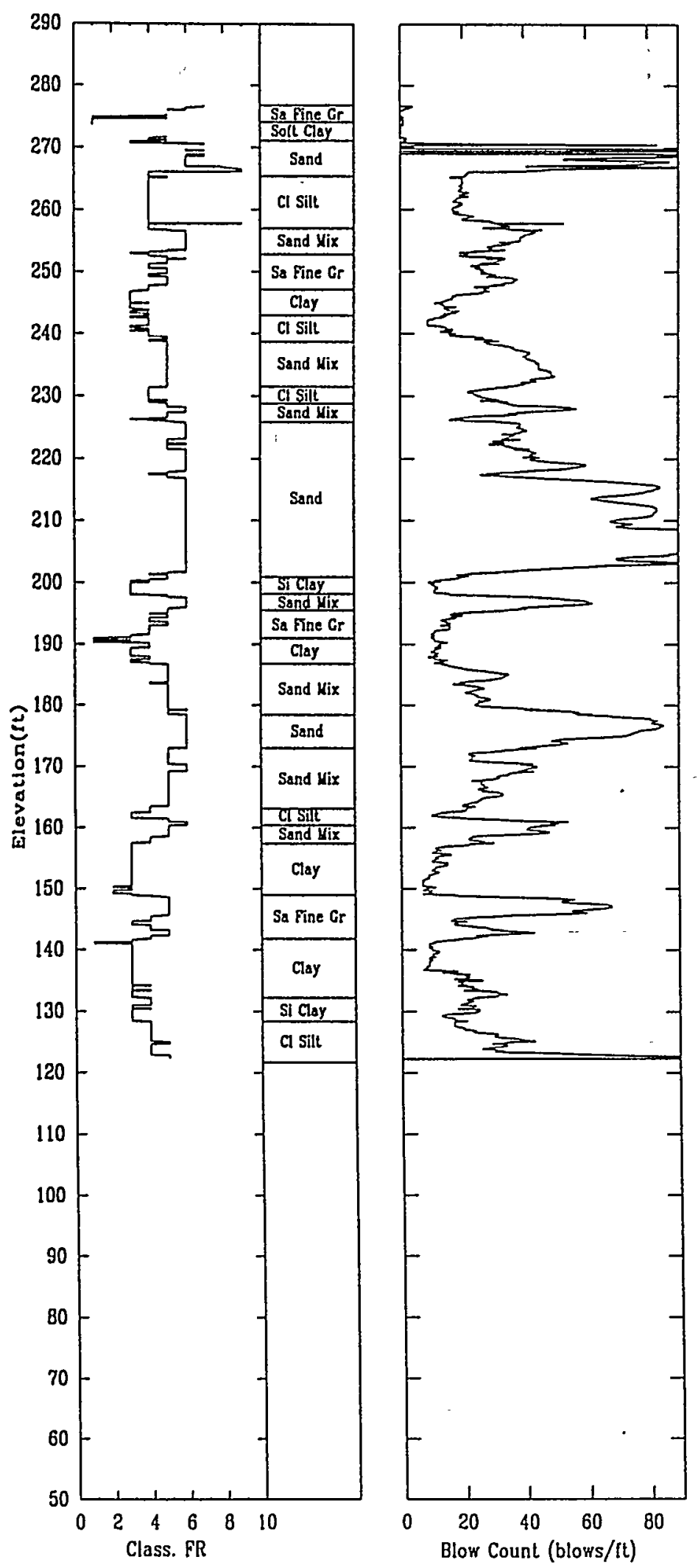


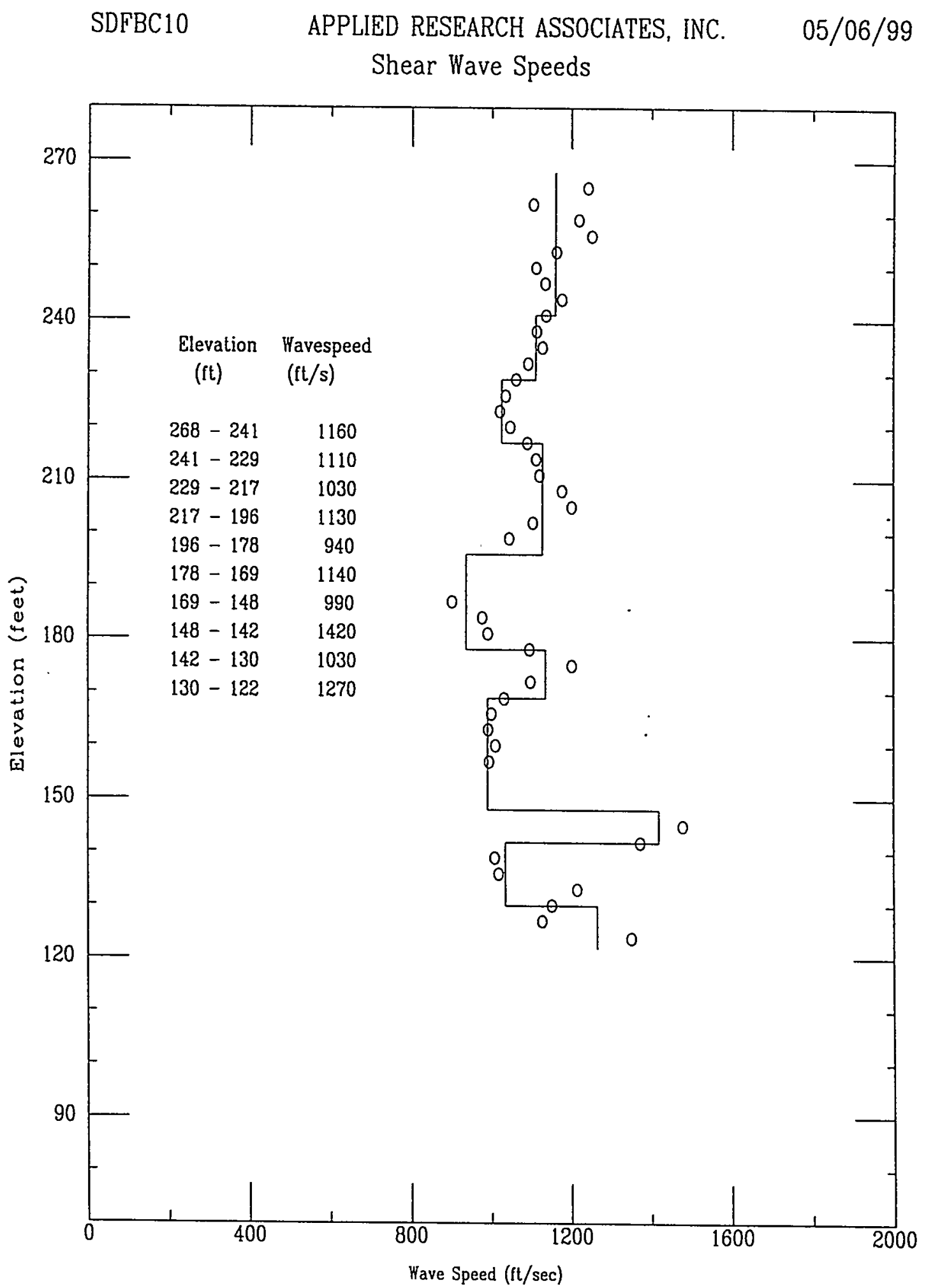

File 306Y902S 


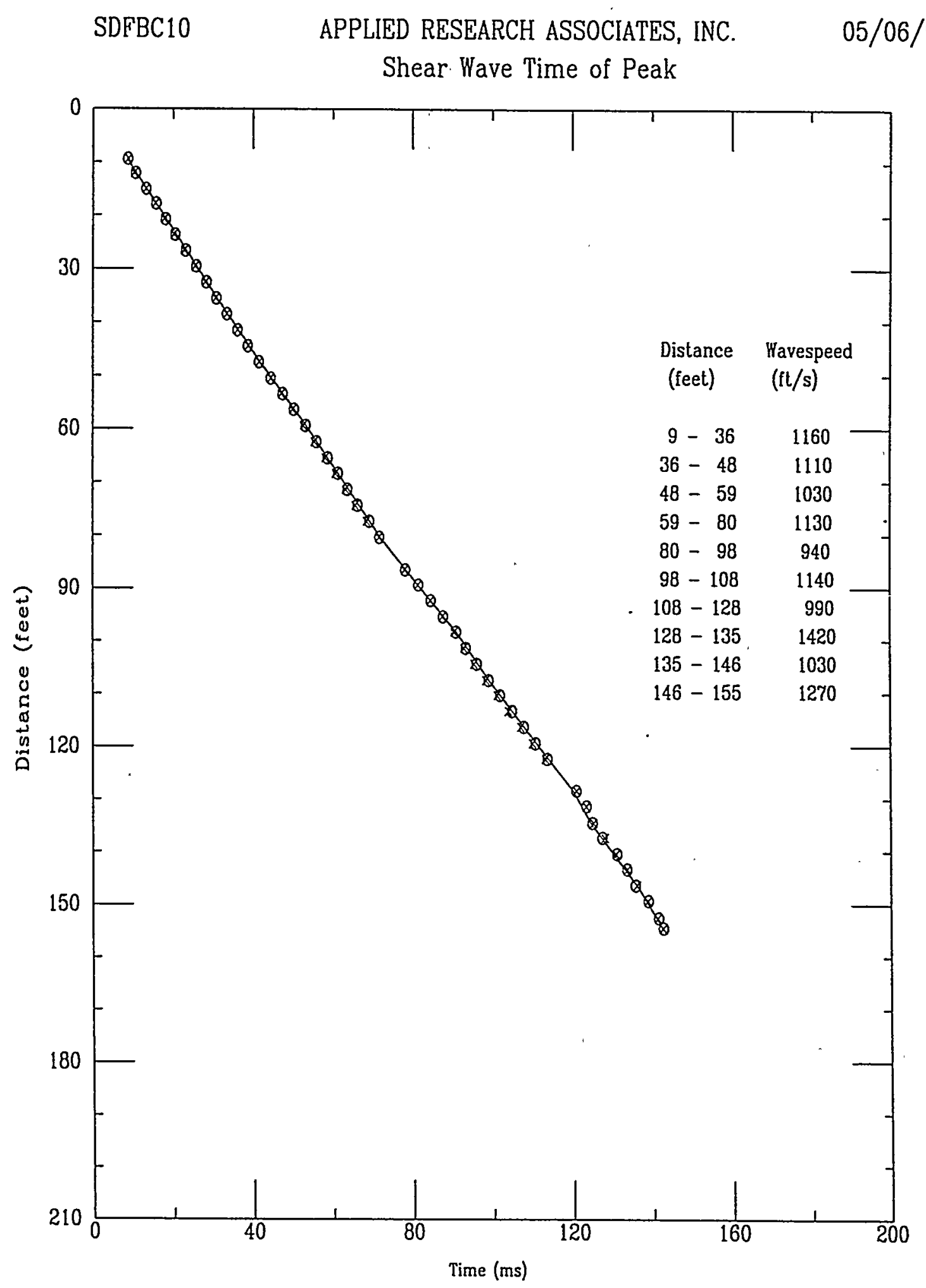

File 306r902S 
Applied Research Associates

SDFBC10
S Wave

05/06/99

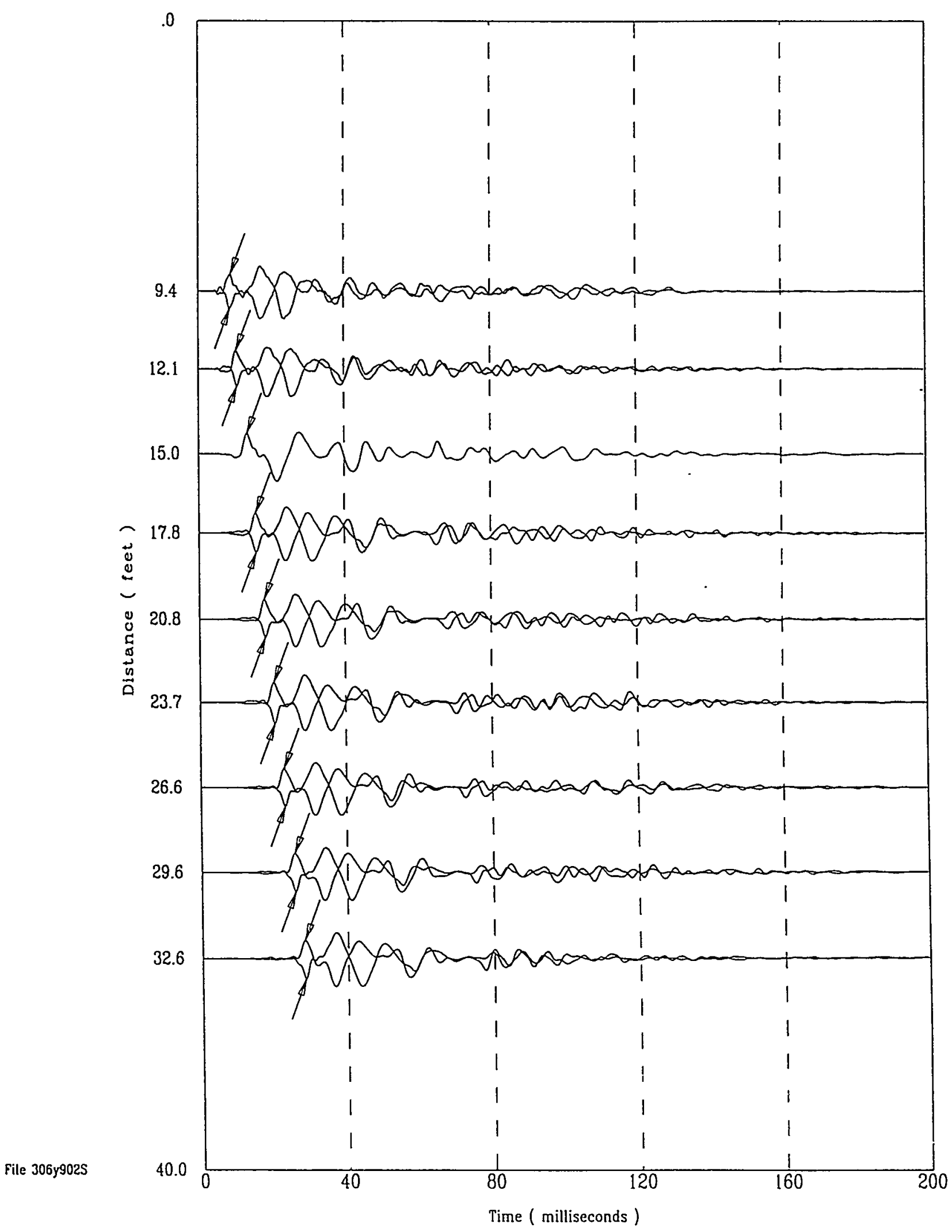


Applied Research Associates

SDFBC10

S Wave

05/06/99

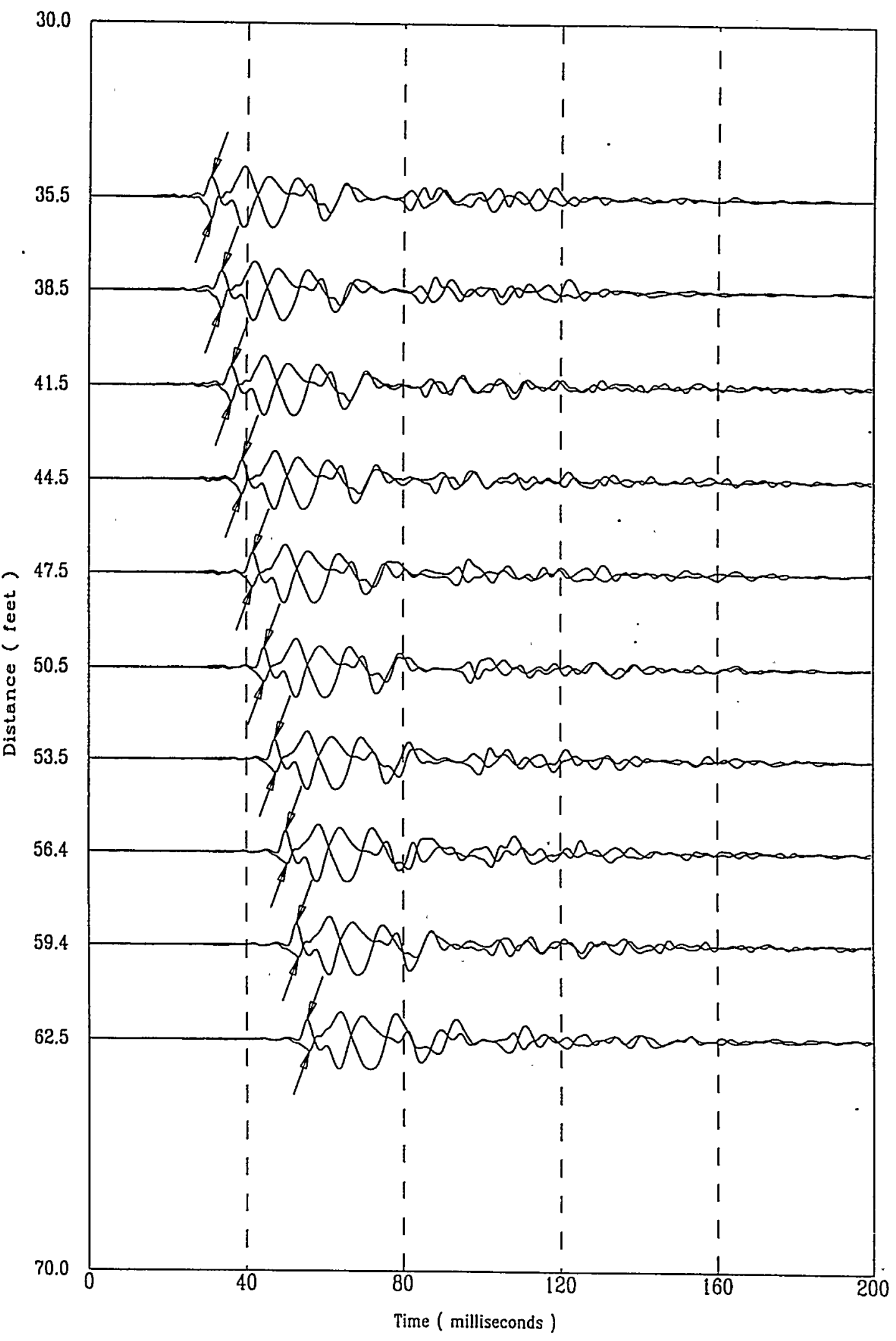



Applied Research Associates
SDFBC10
S Wave
05/06/99

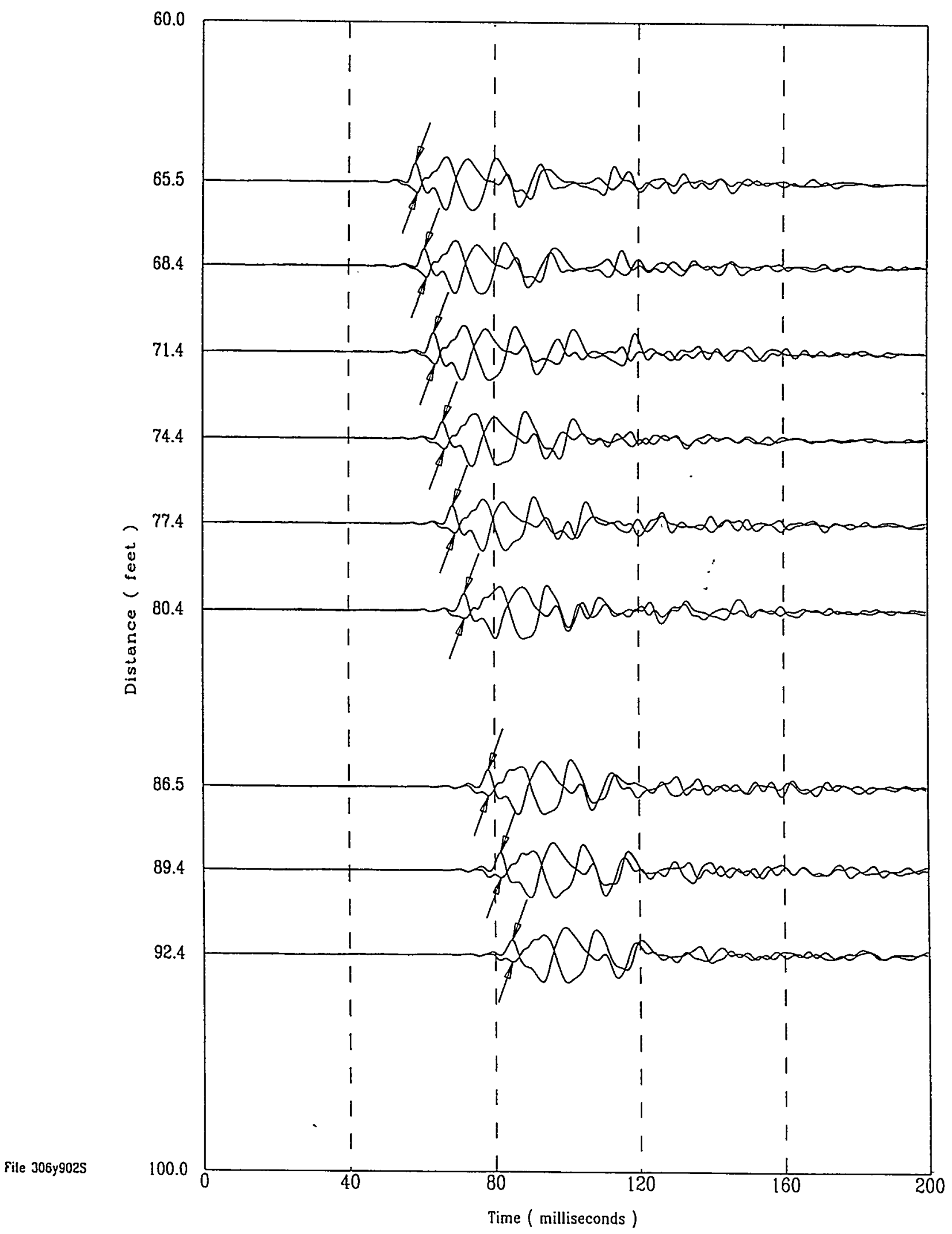


Applied Research Associates SDFBC10
$S$ Wave

05/06/99

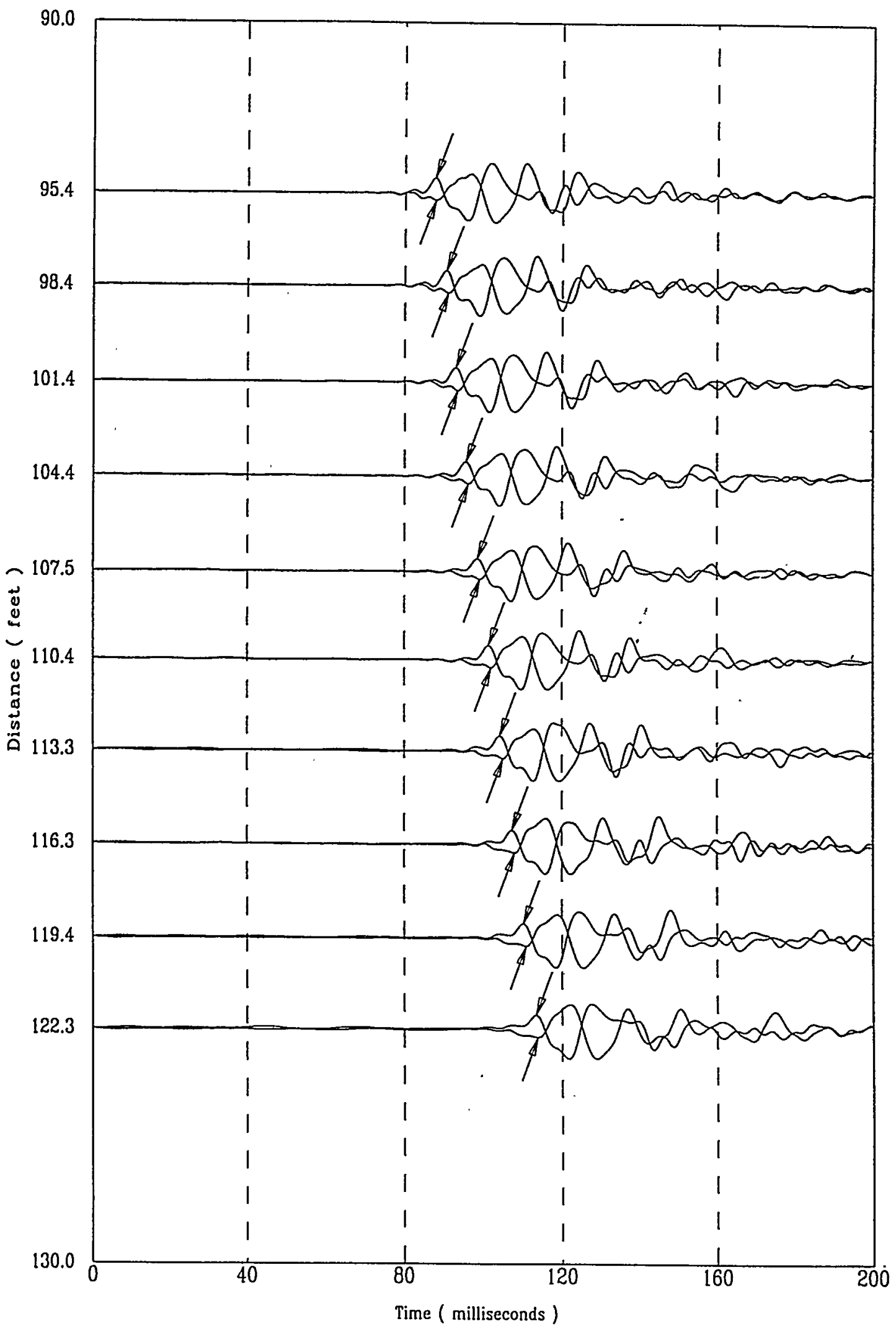




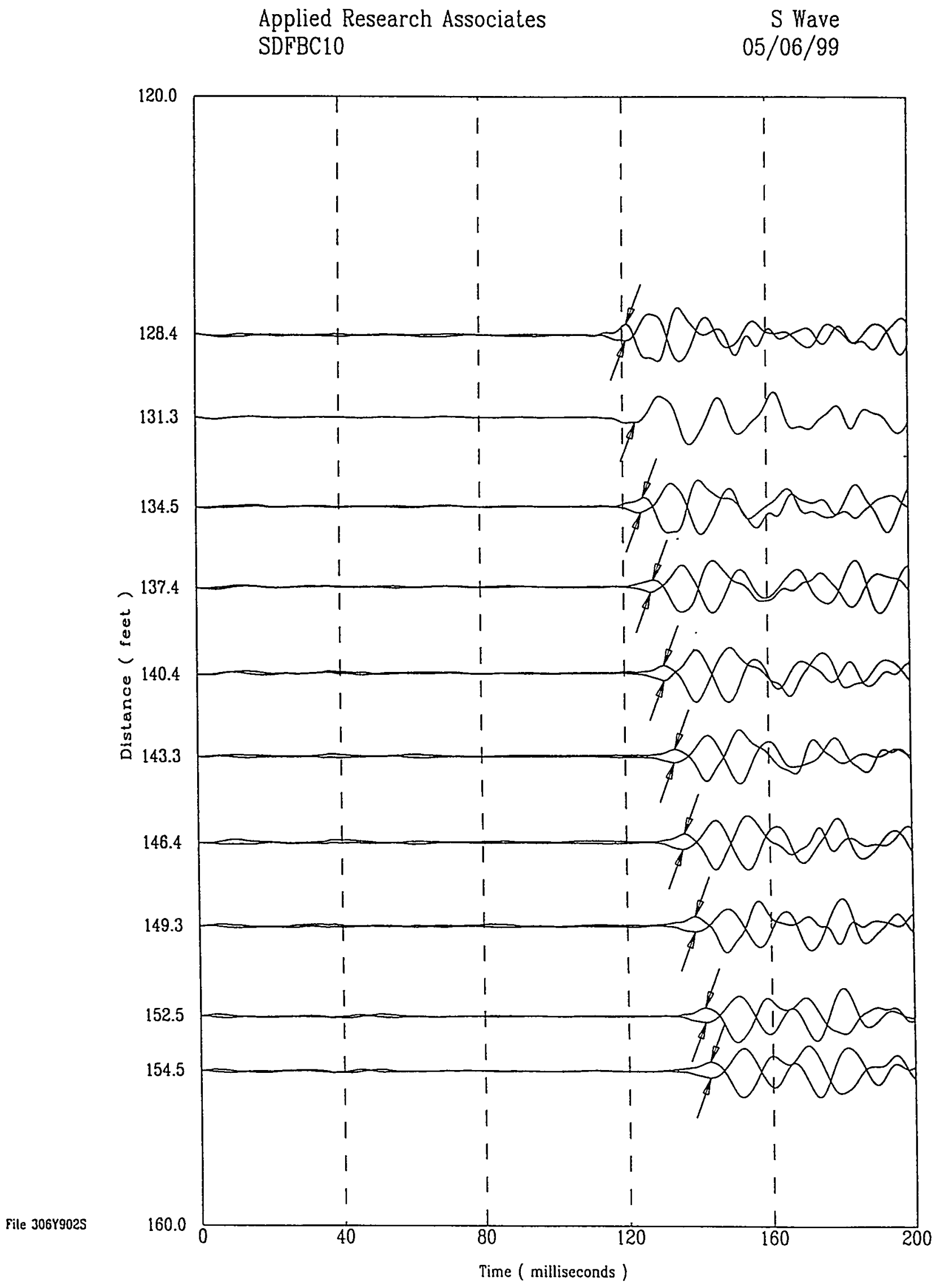


SDFBC10

APPLIED RESEARCH ASSOCIATES, INC. $\quad$ 05/06/99

Compression Wave Speeds

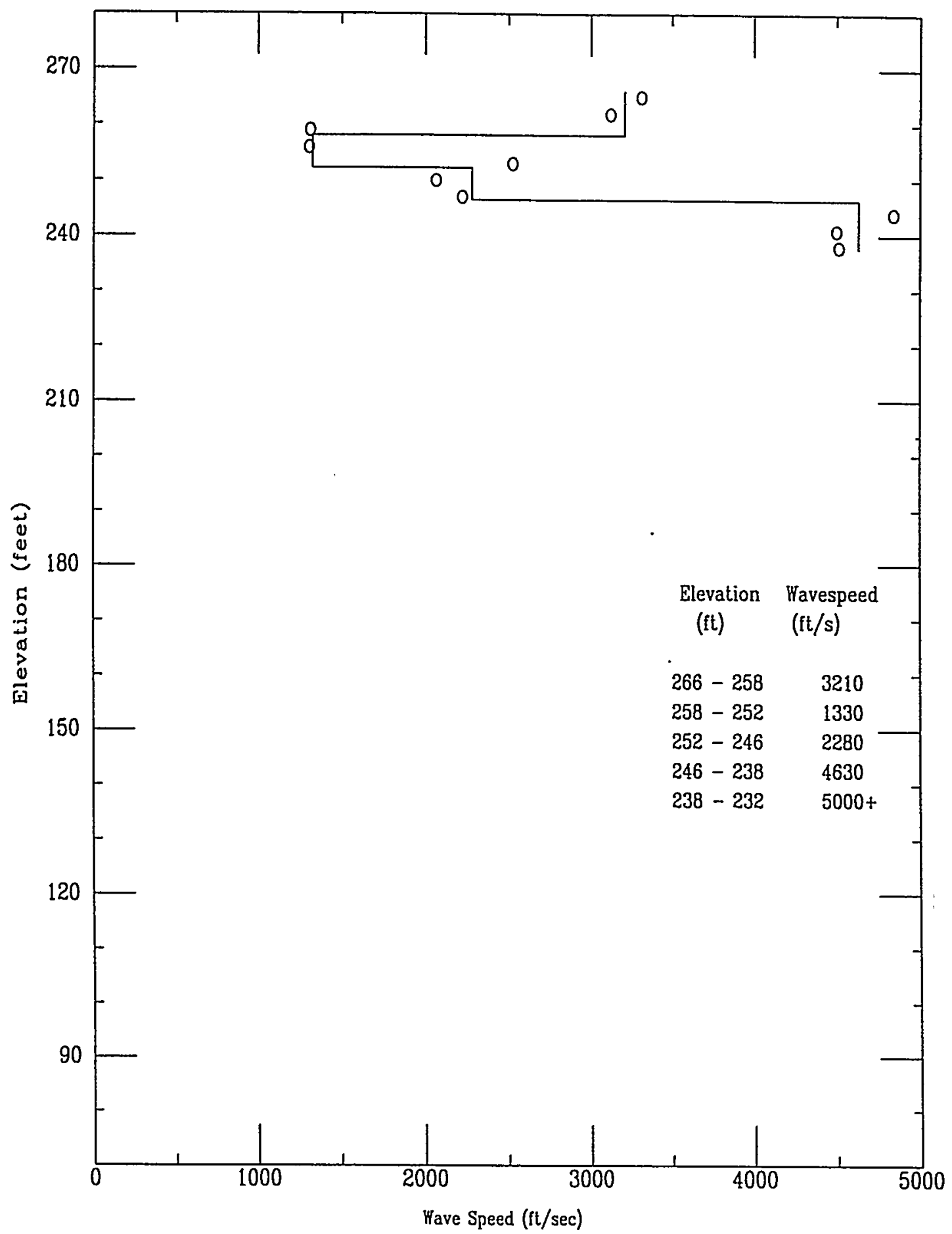

File 306Y902S 


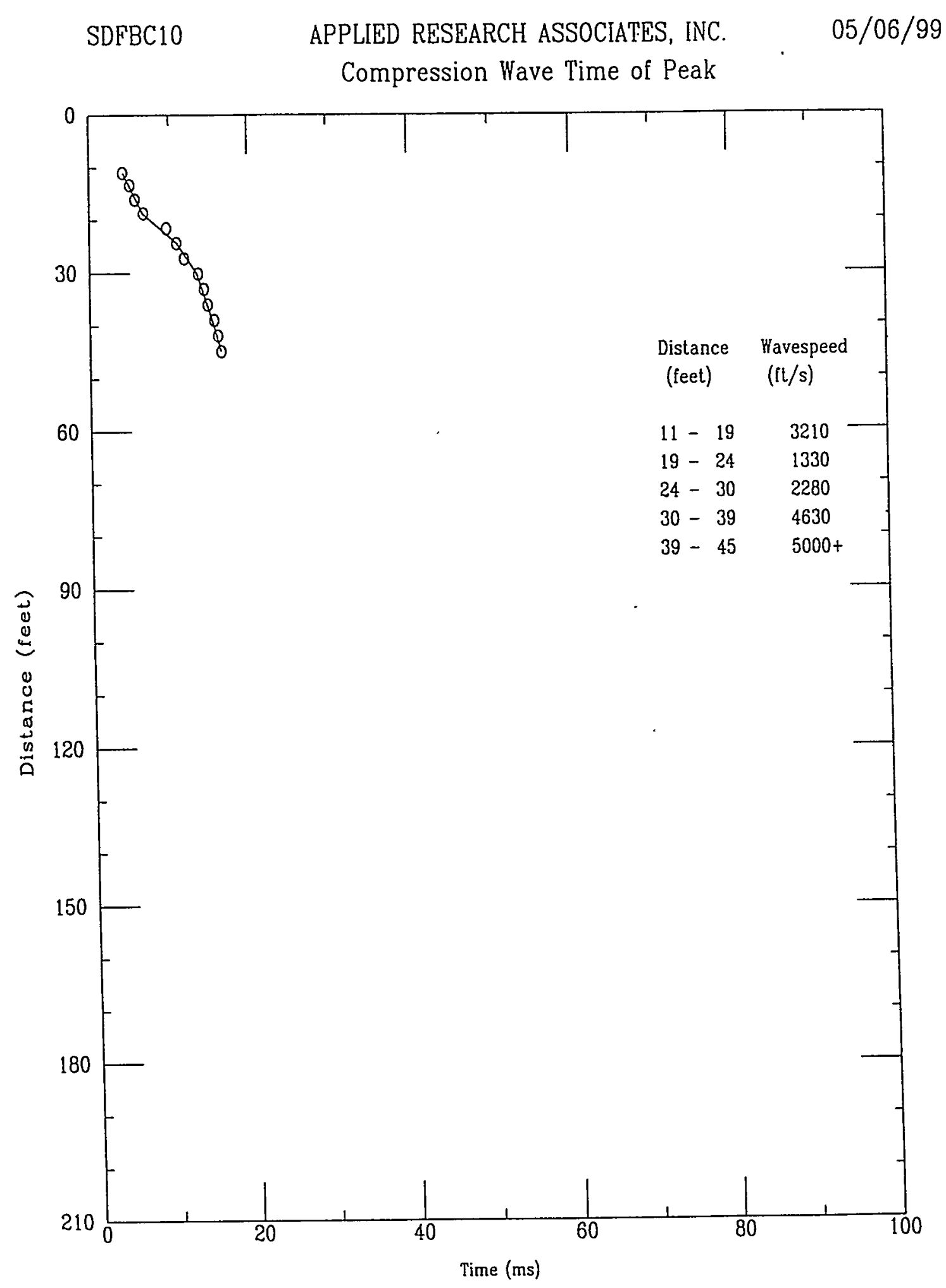

File $306 Y 9025$ 
Applied Research Associates

SDFBC10

P Wave

05/06/99

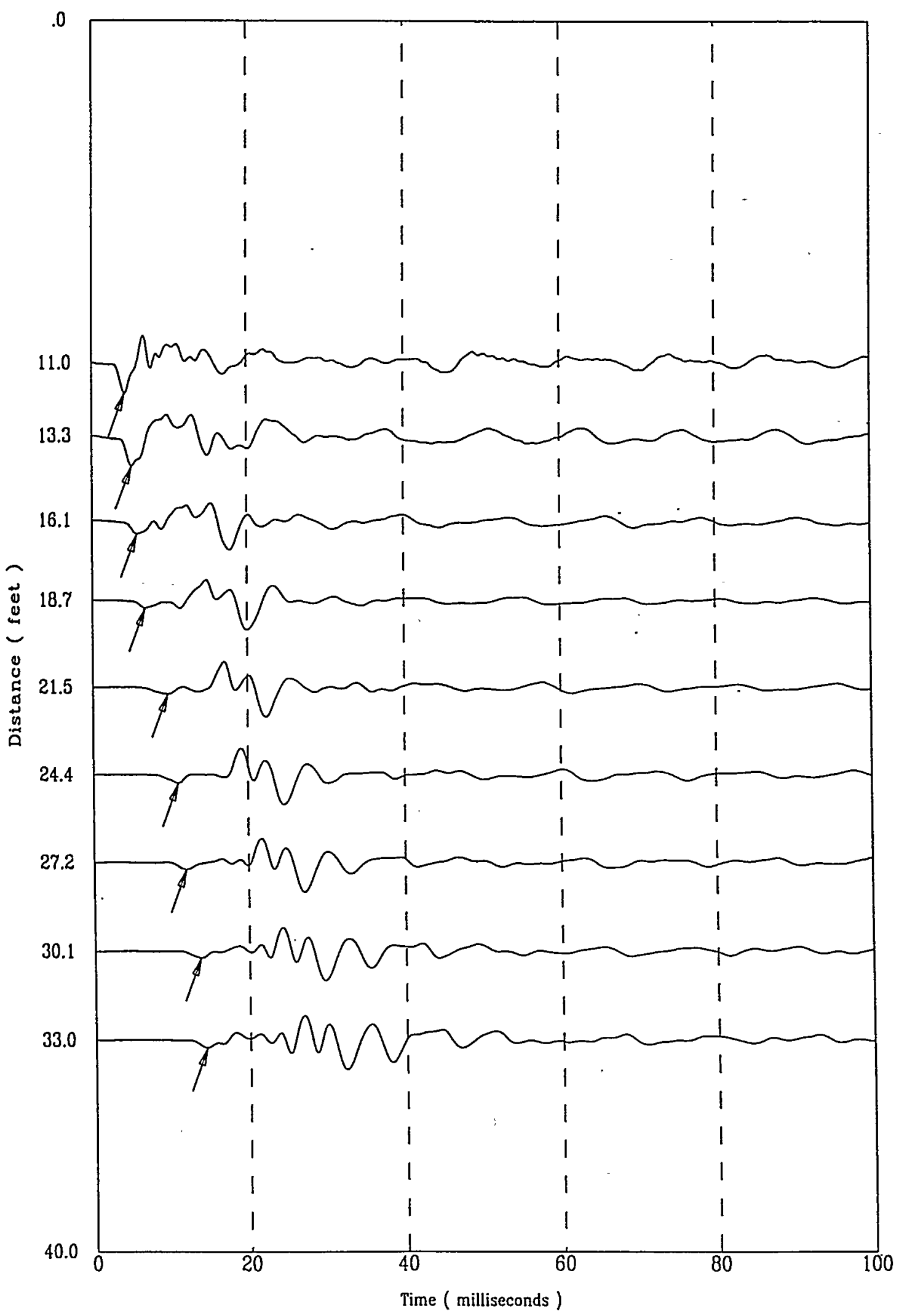


SCDFB14 APPLIED RESEARCH ASSOCIATES, INC.

North 72764.3 East 65025.3 Elevation 279.1
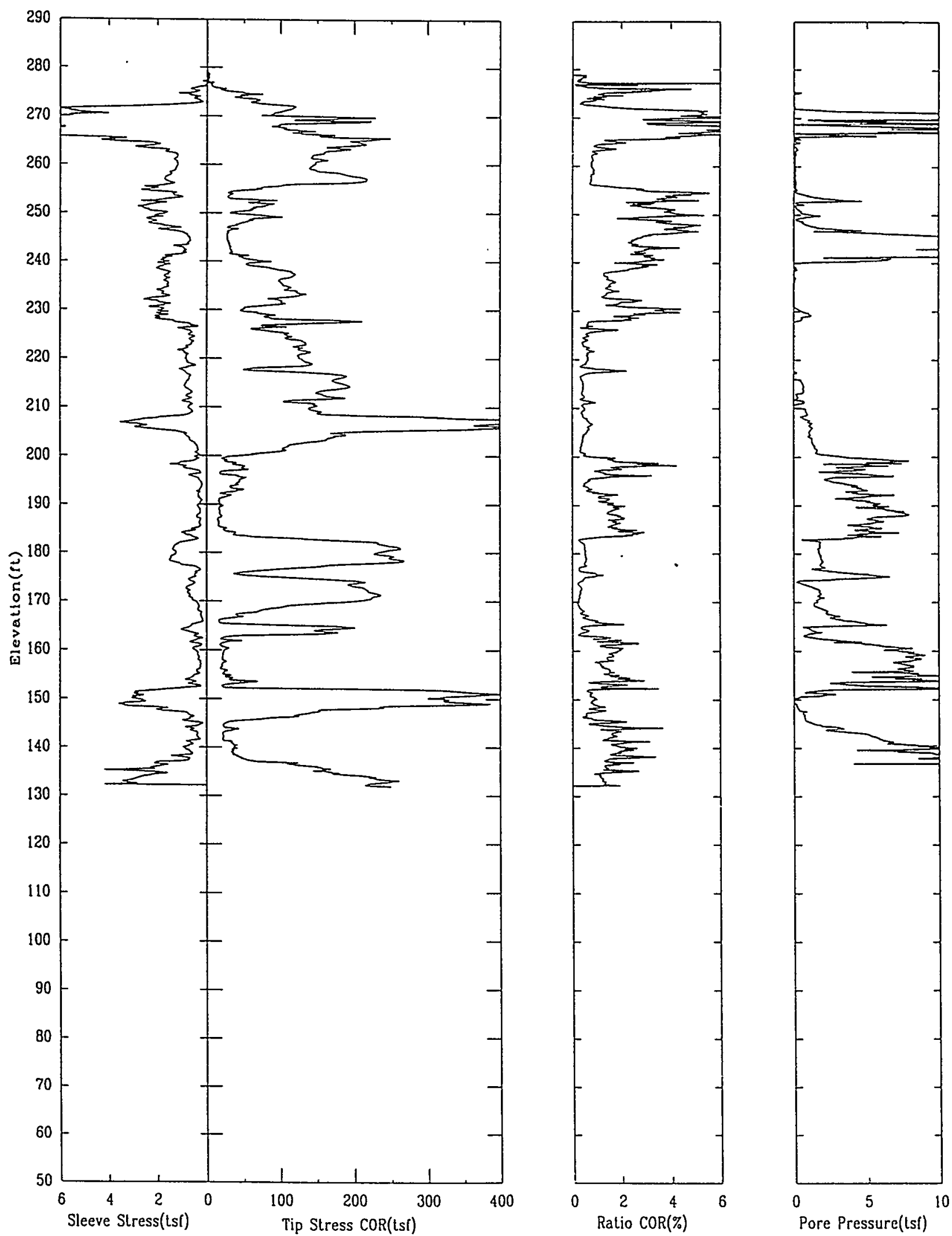
North 72764.3 East 65025.3 Elevation 279.1
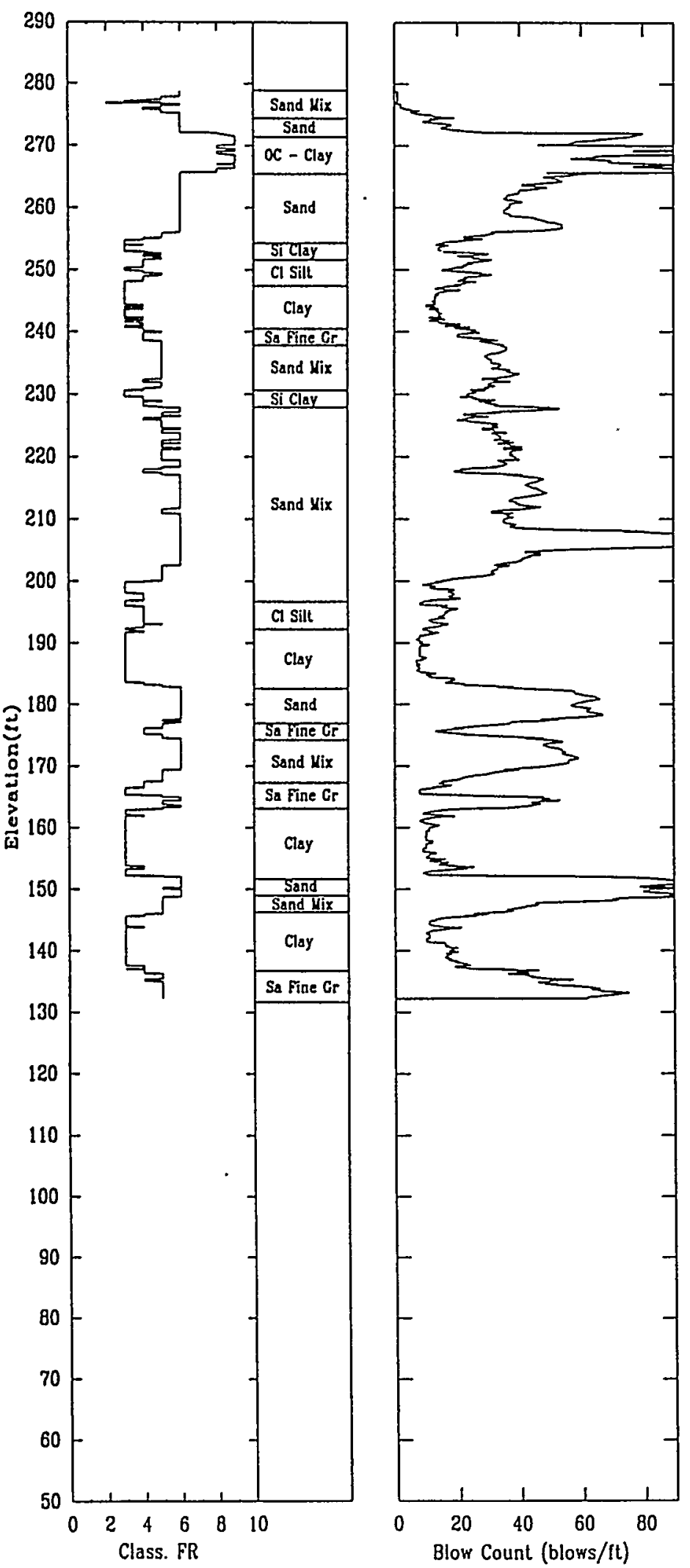

File $310 y 901 . E C P$ 


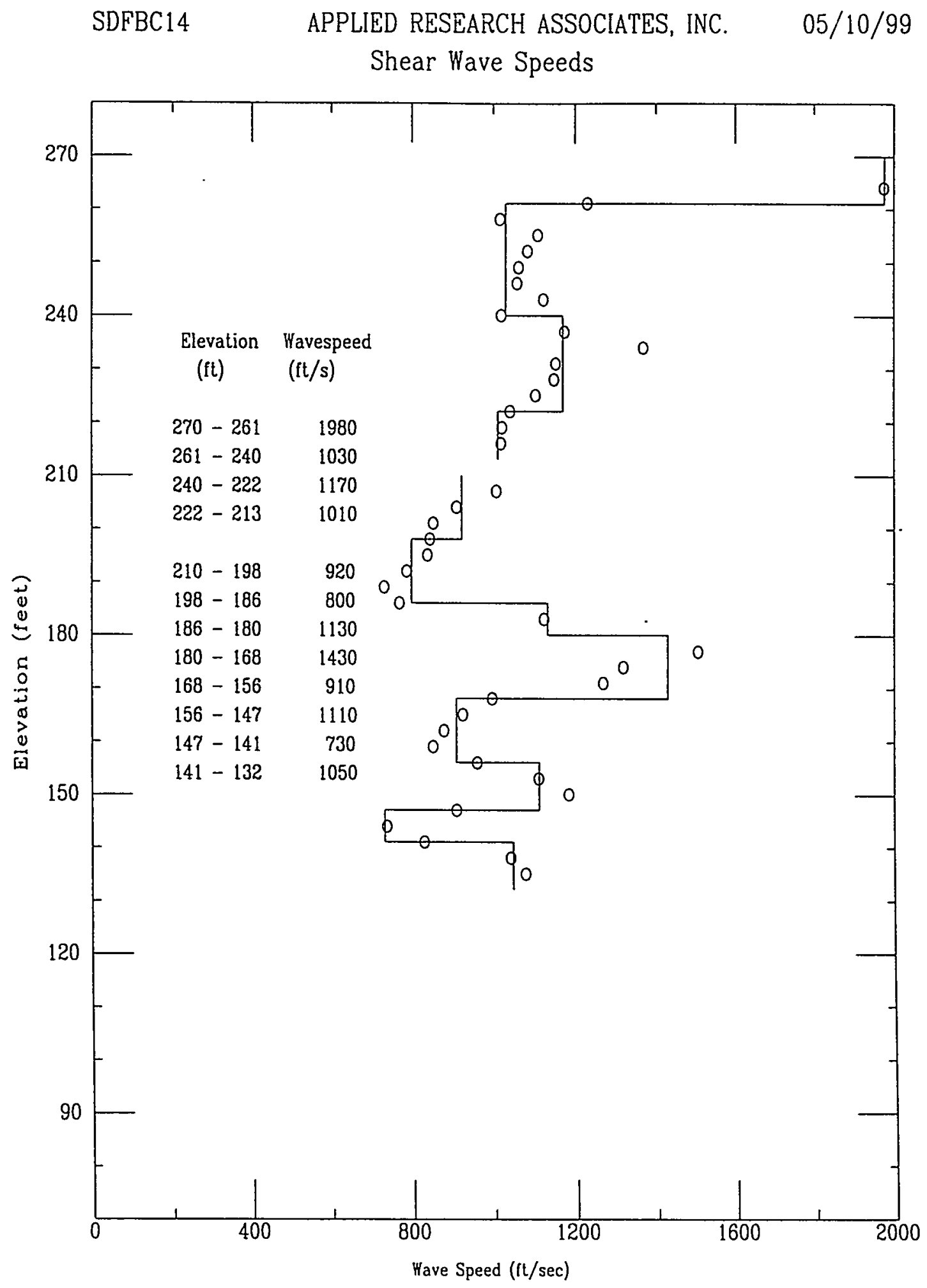

File 310y901S 


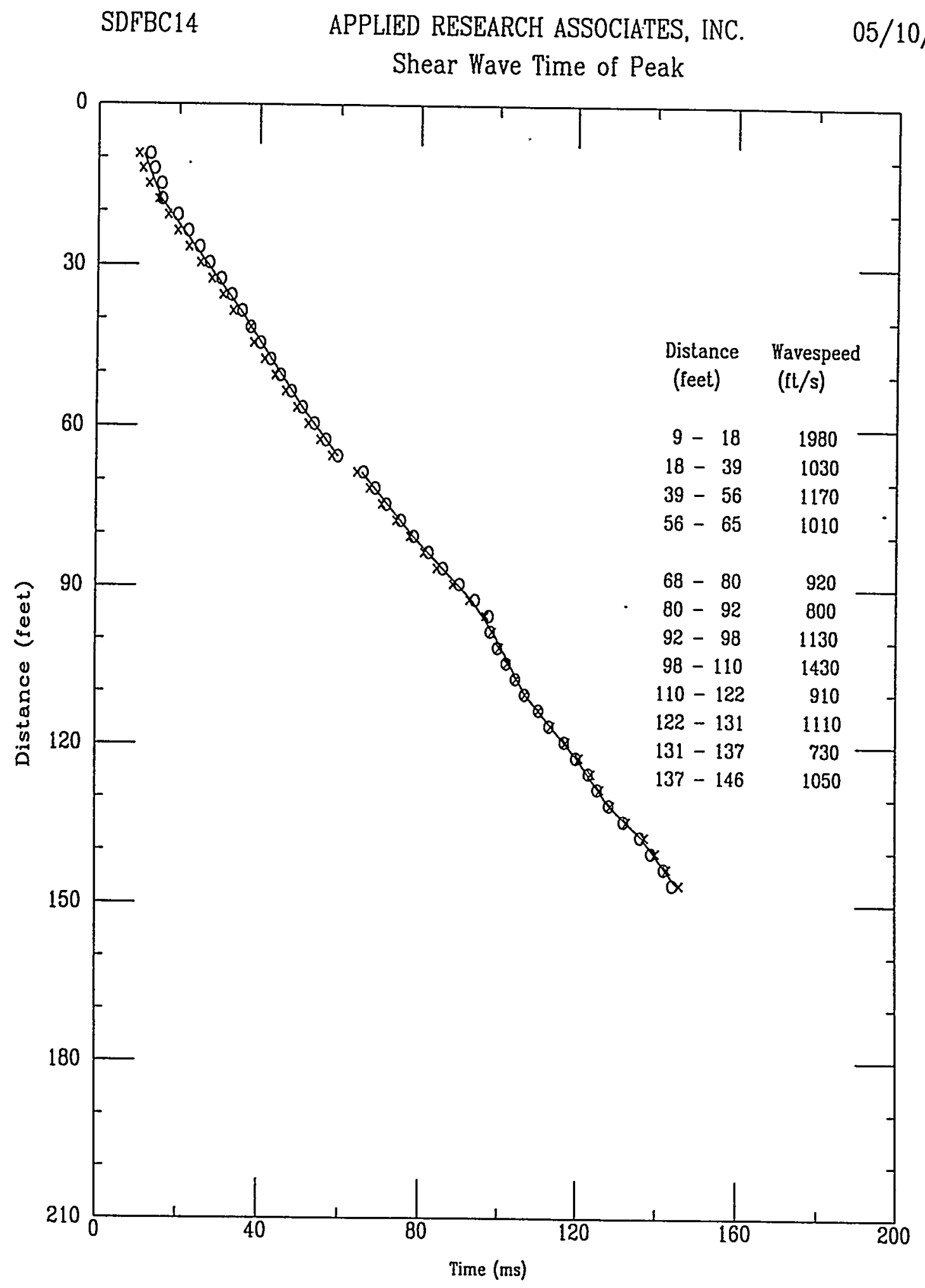

File $310 y 9015$ 


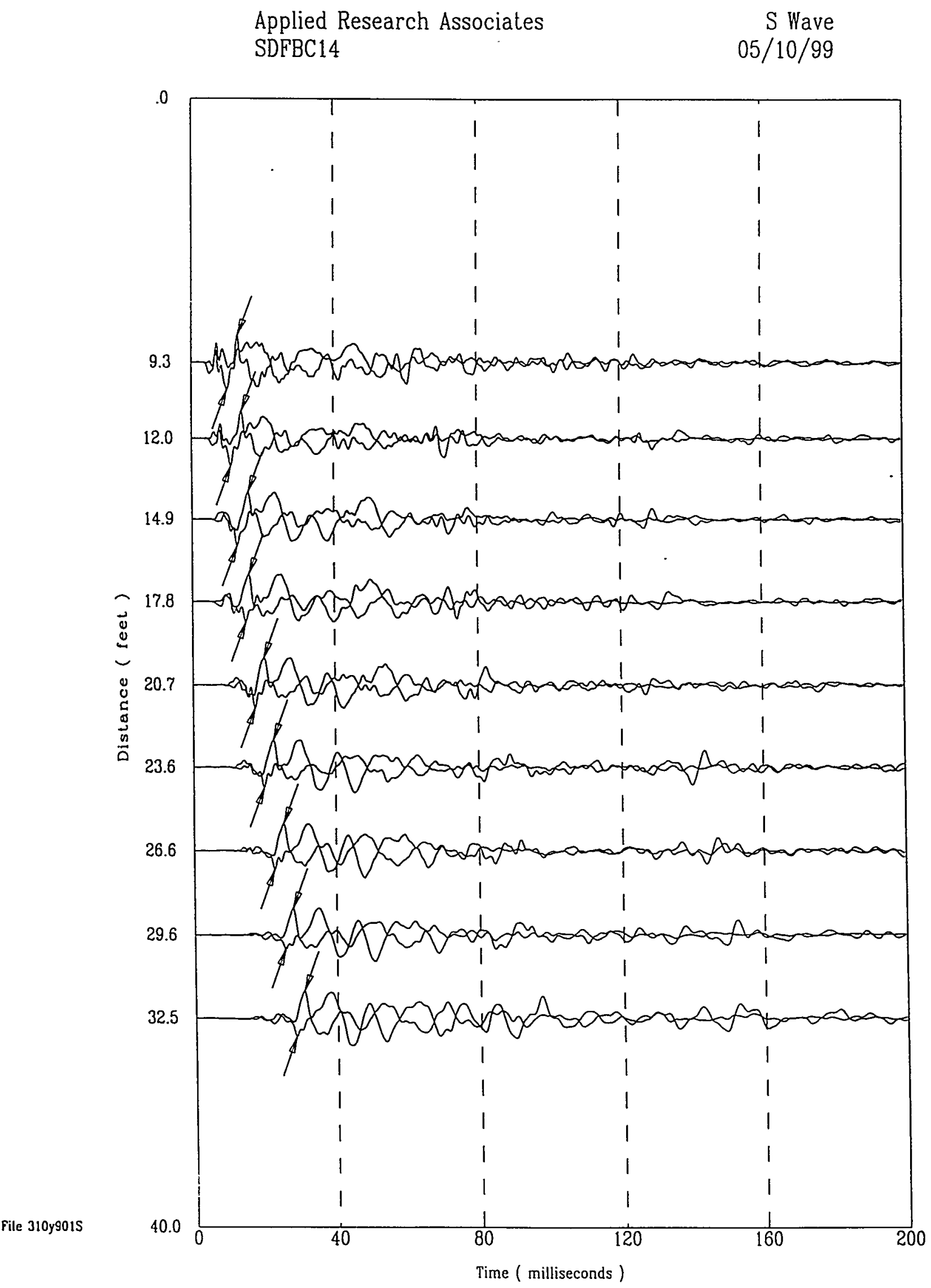


Applied Research Associates

SDFBC14

S Wave

05/10/99

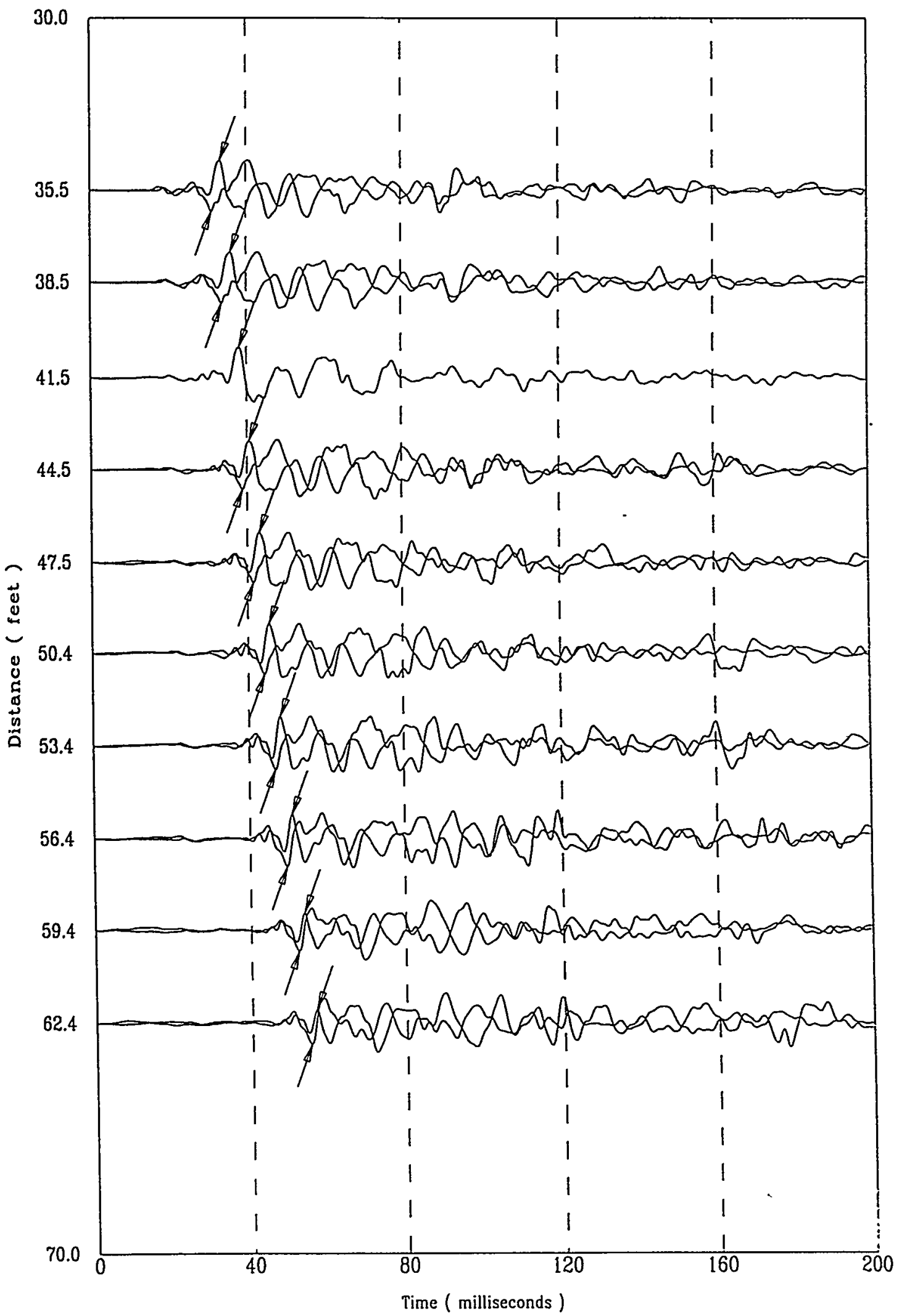


Applied Research Associates

SDFBC14

S Wave

05/10/99

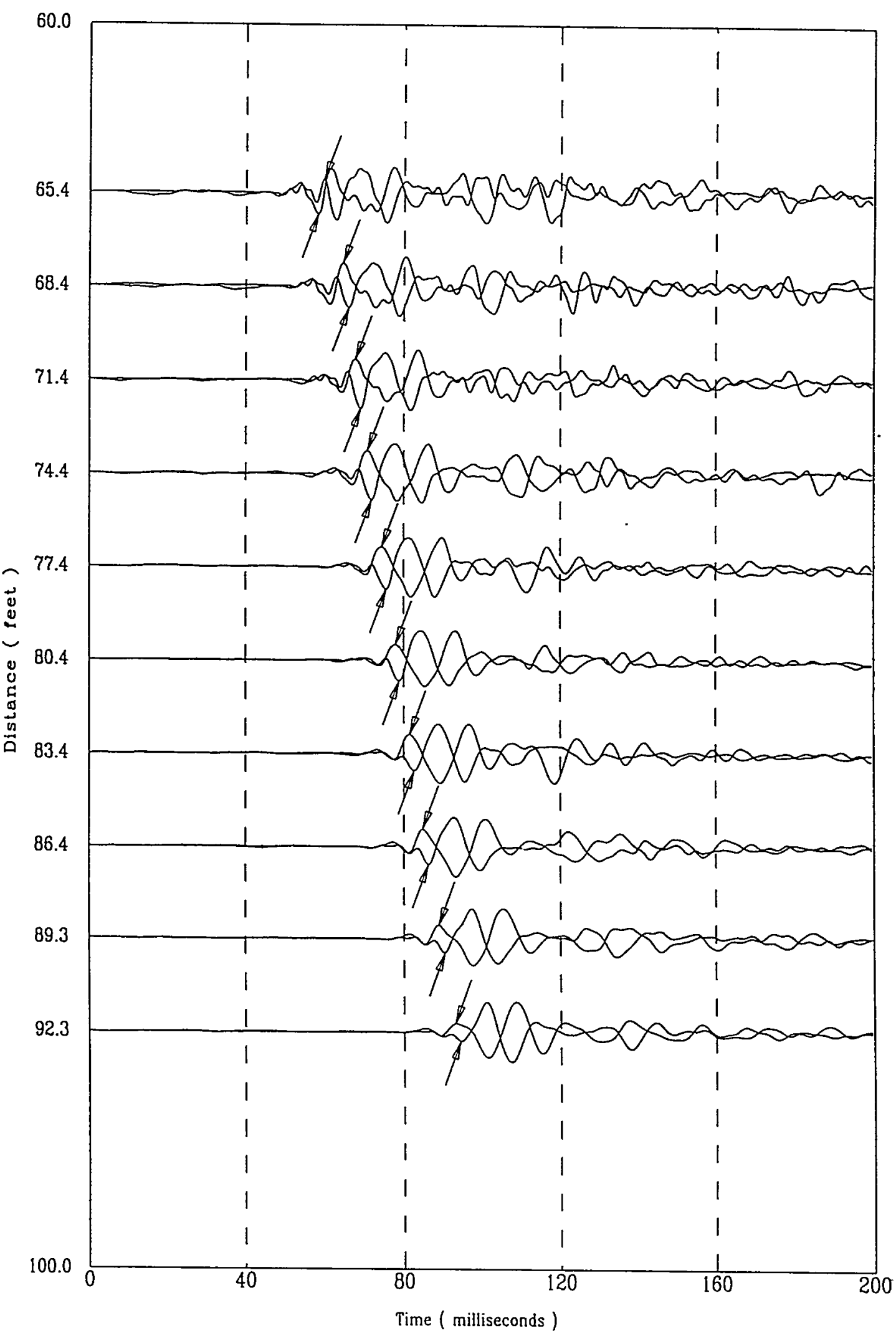


Applied Research Associates SDFBC14

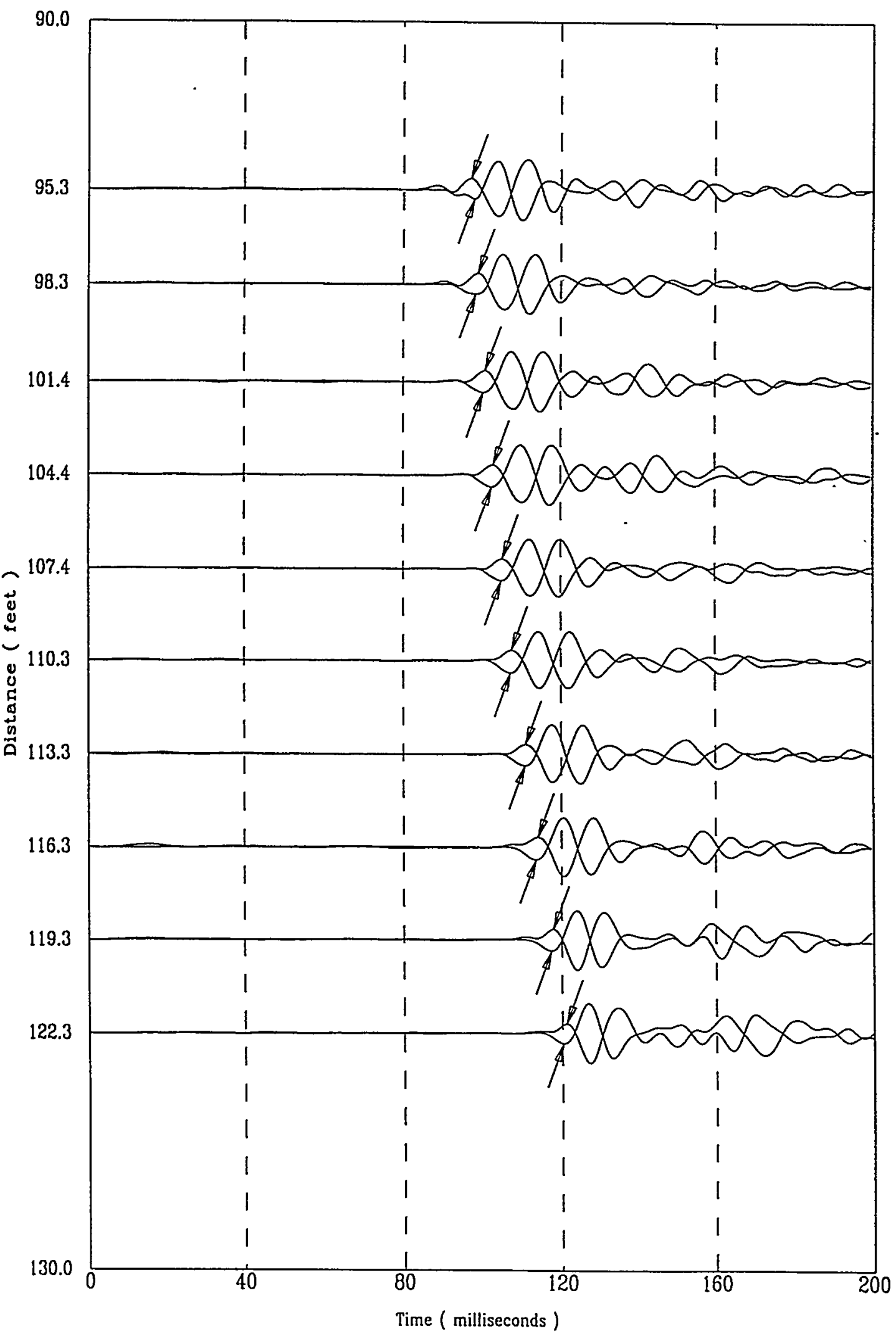


Applied Research Associates

SDFBC14

S Wave

$05 / 10 / 99$

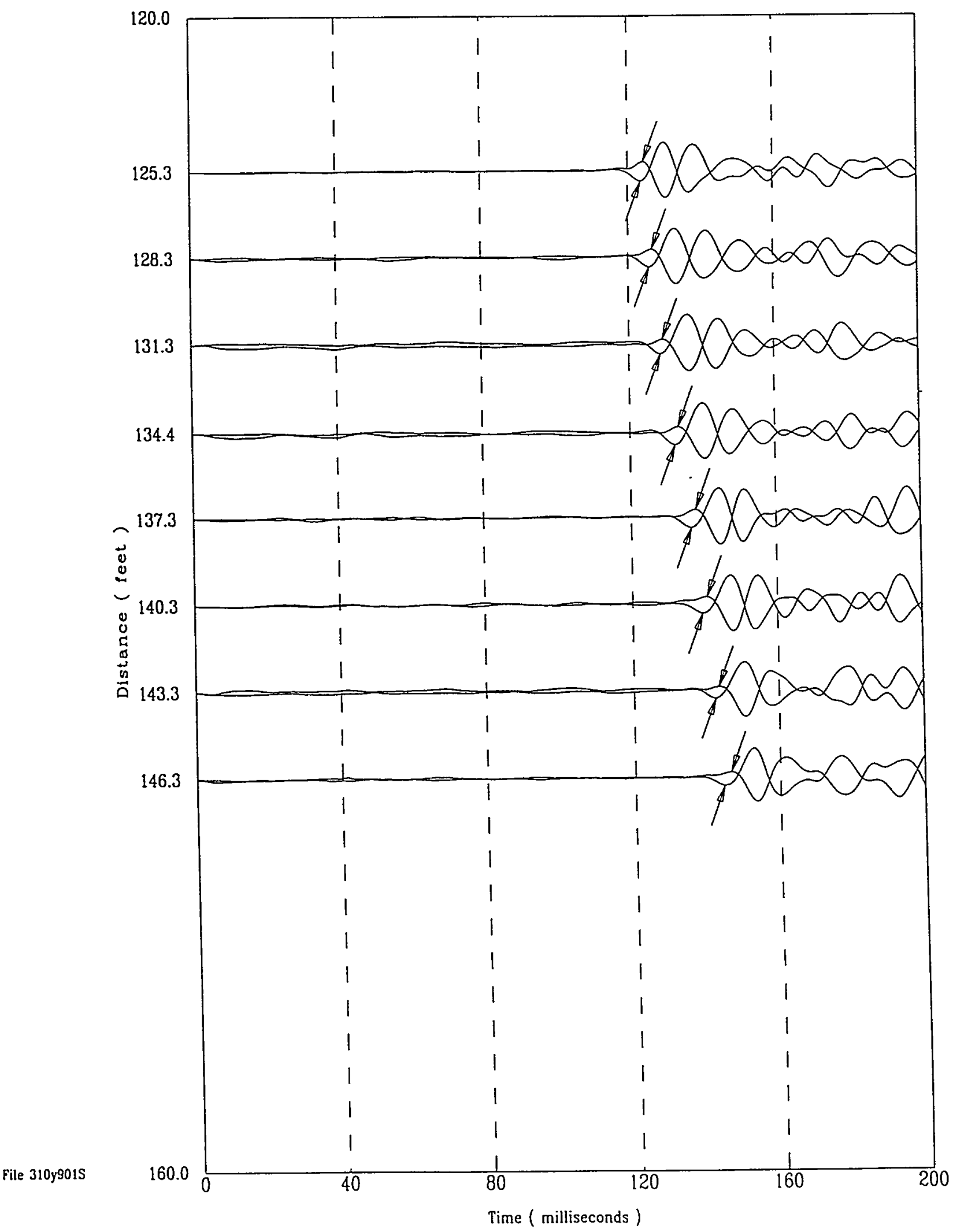




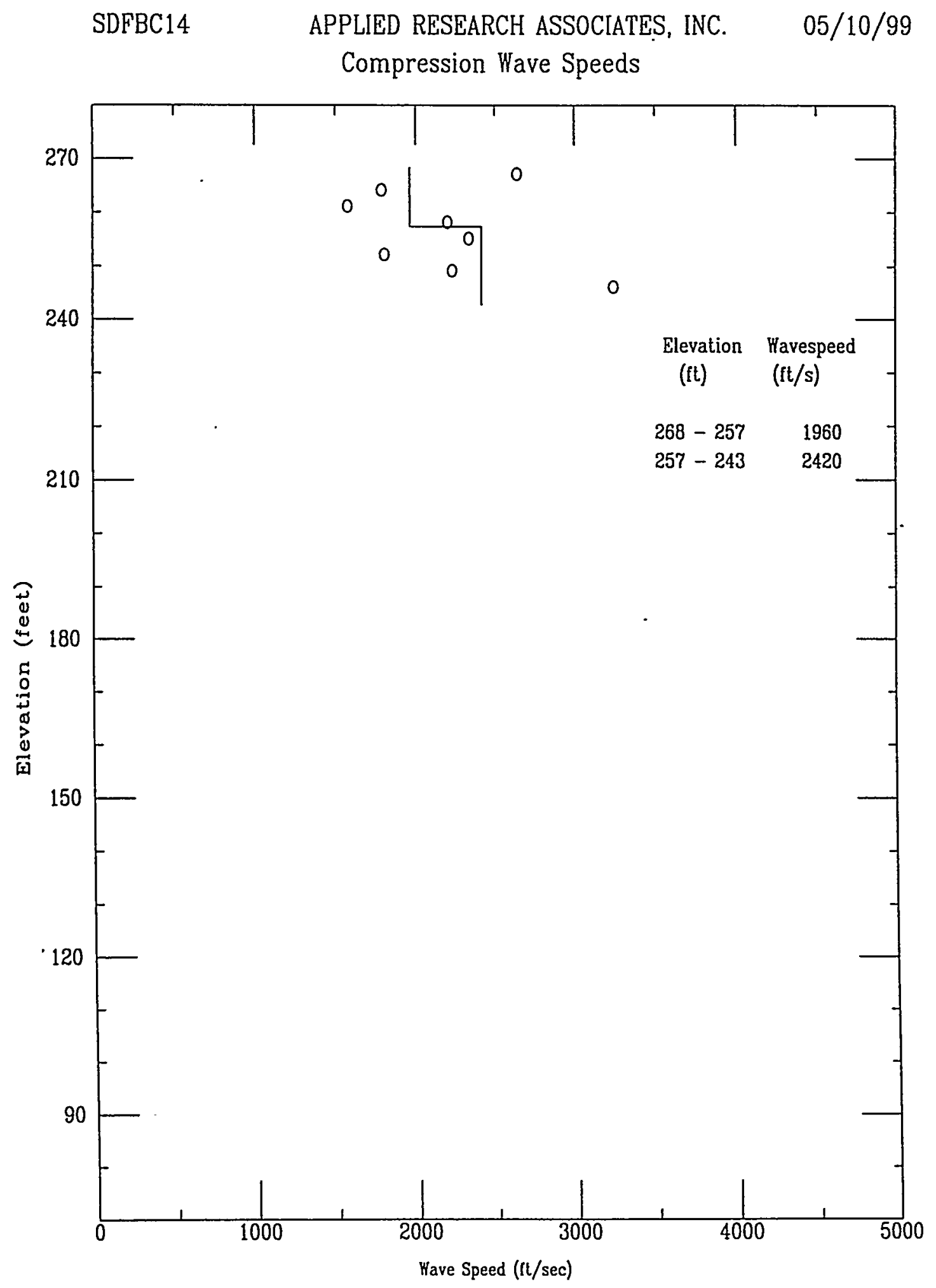

File 3torgots 


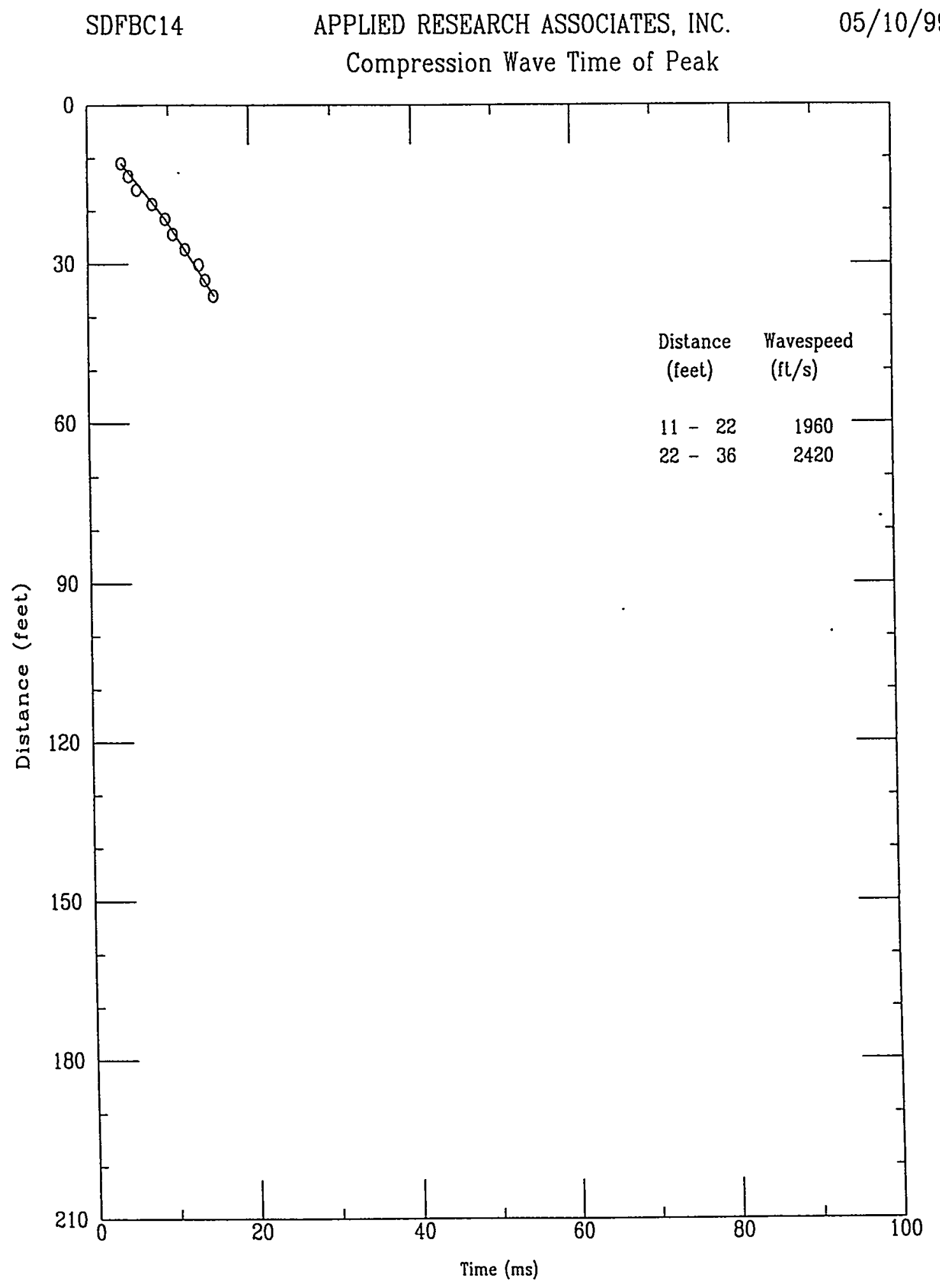

File 310 Y901S 
SDFBC15 APPLIED RESEARCH ASSOCIATES, INC. 05/07/99

North 72768.8 East 65444.7 Elevation 275.0
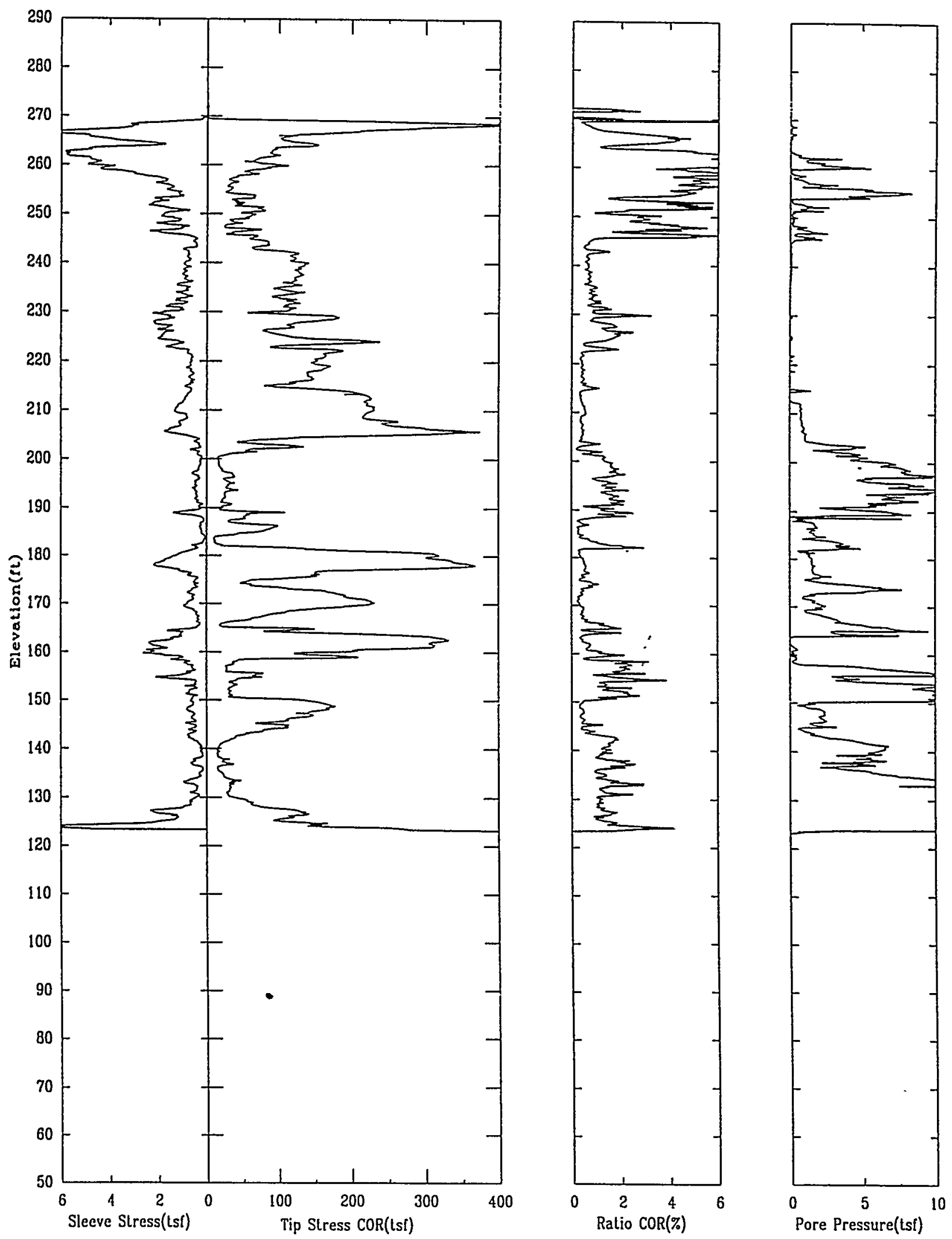
SDFBC15

APPLIED RESEARCH ASSOCIATES, INC.

$05 / 07 / 99$

North 72768.8 East 65444.7 Elevation 275.0
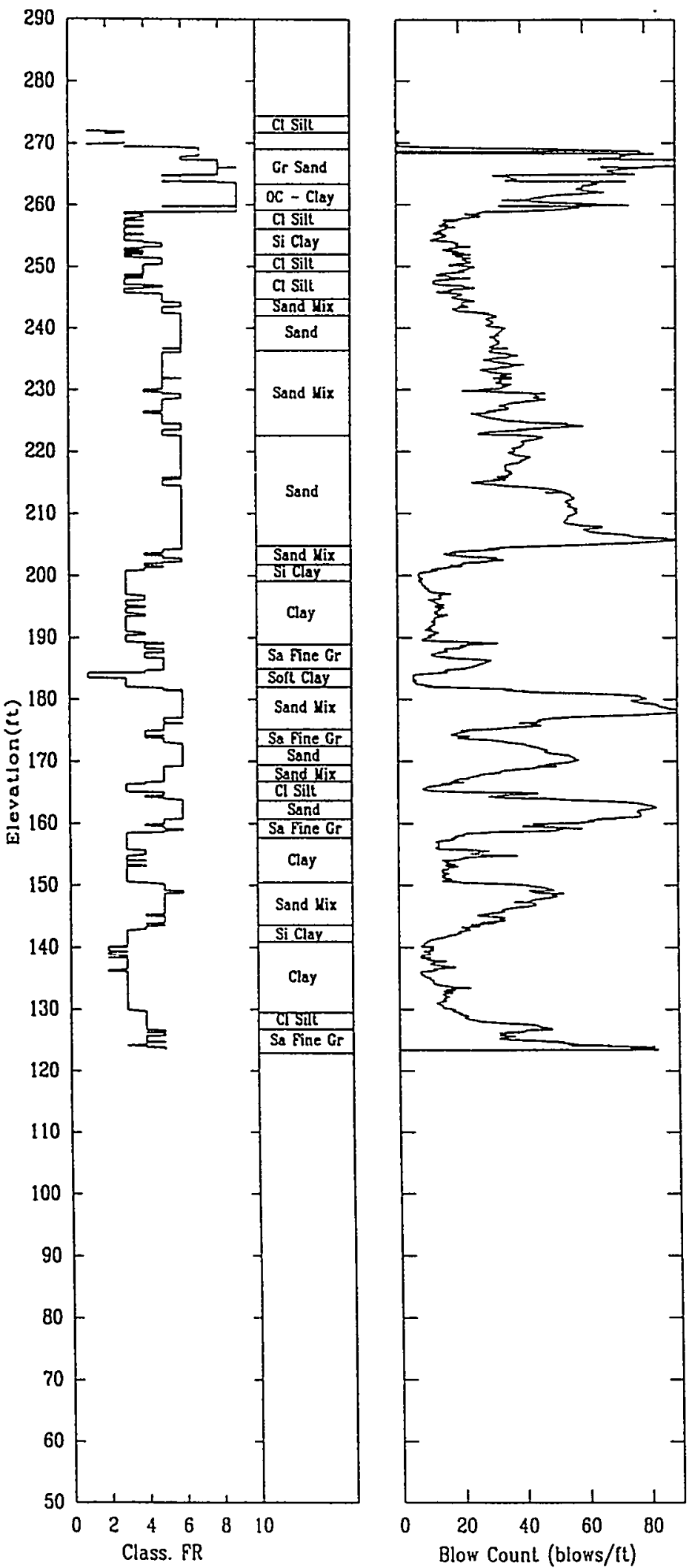


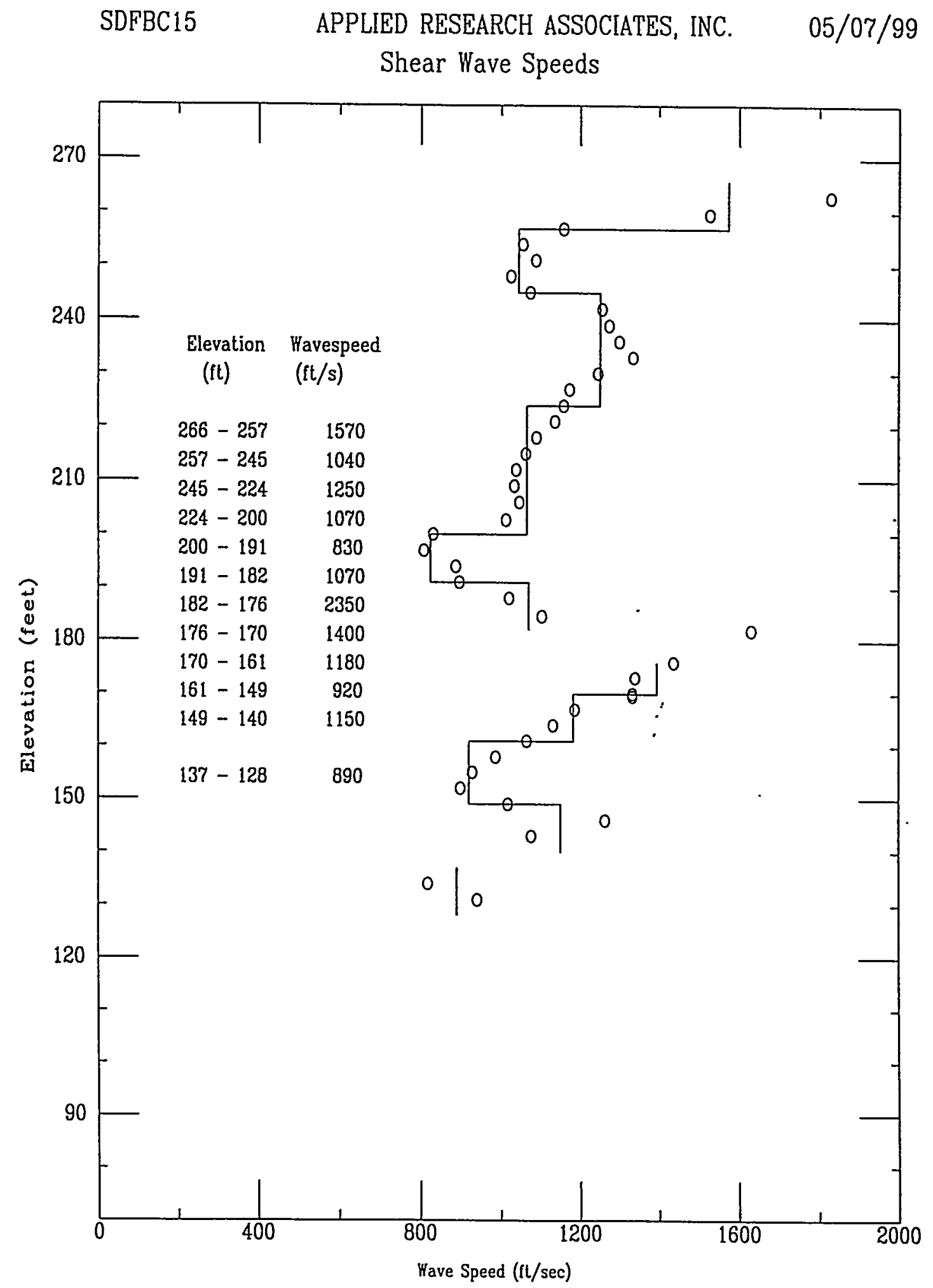

File 307Y901S 


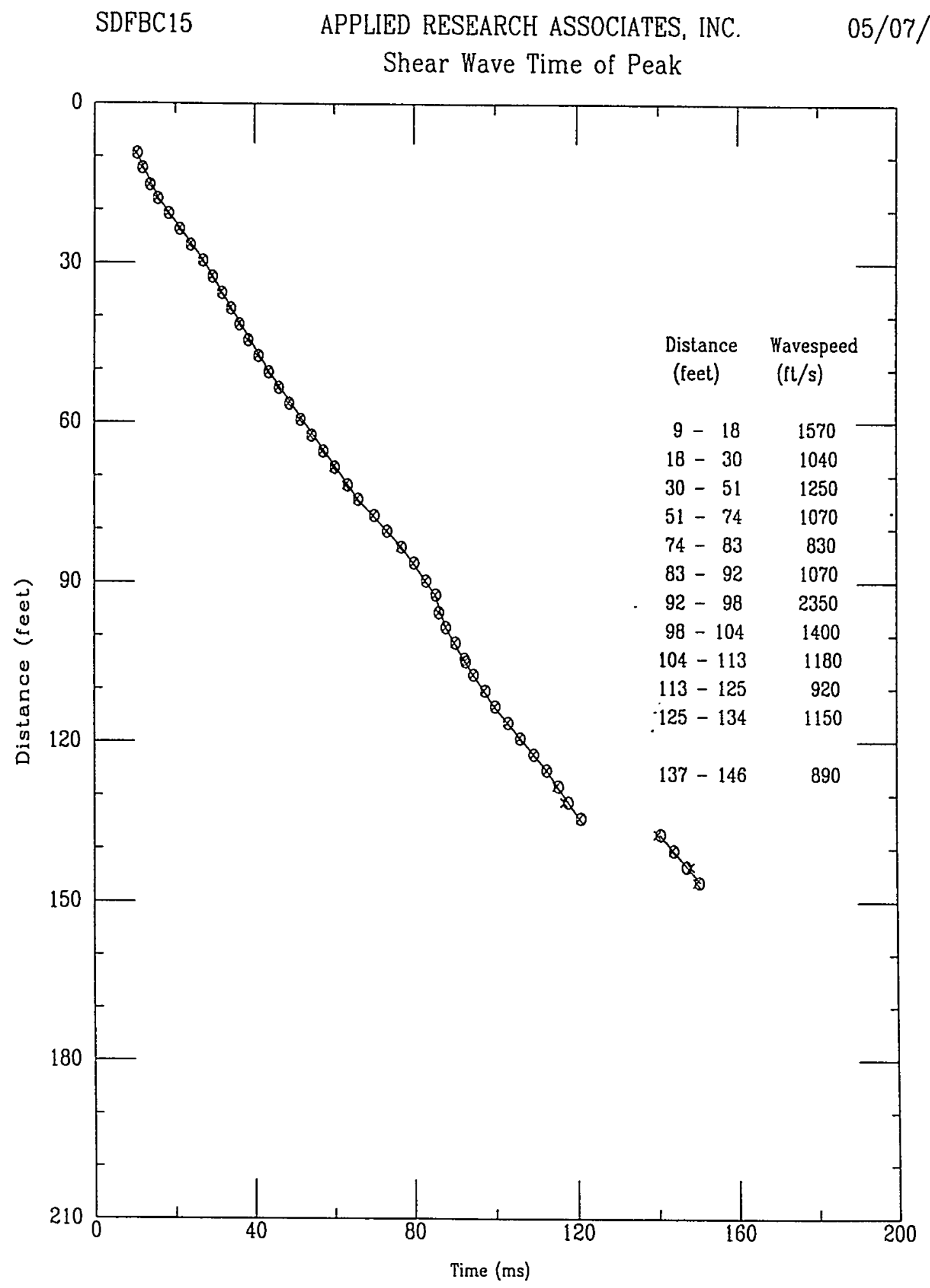

File 307Y901S 
Ápplied Research Associates

SDFBC15

$S$ Wave

05/07/99

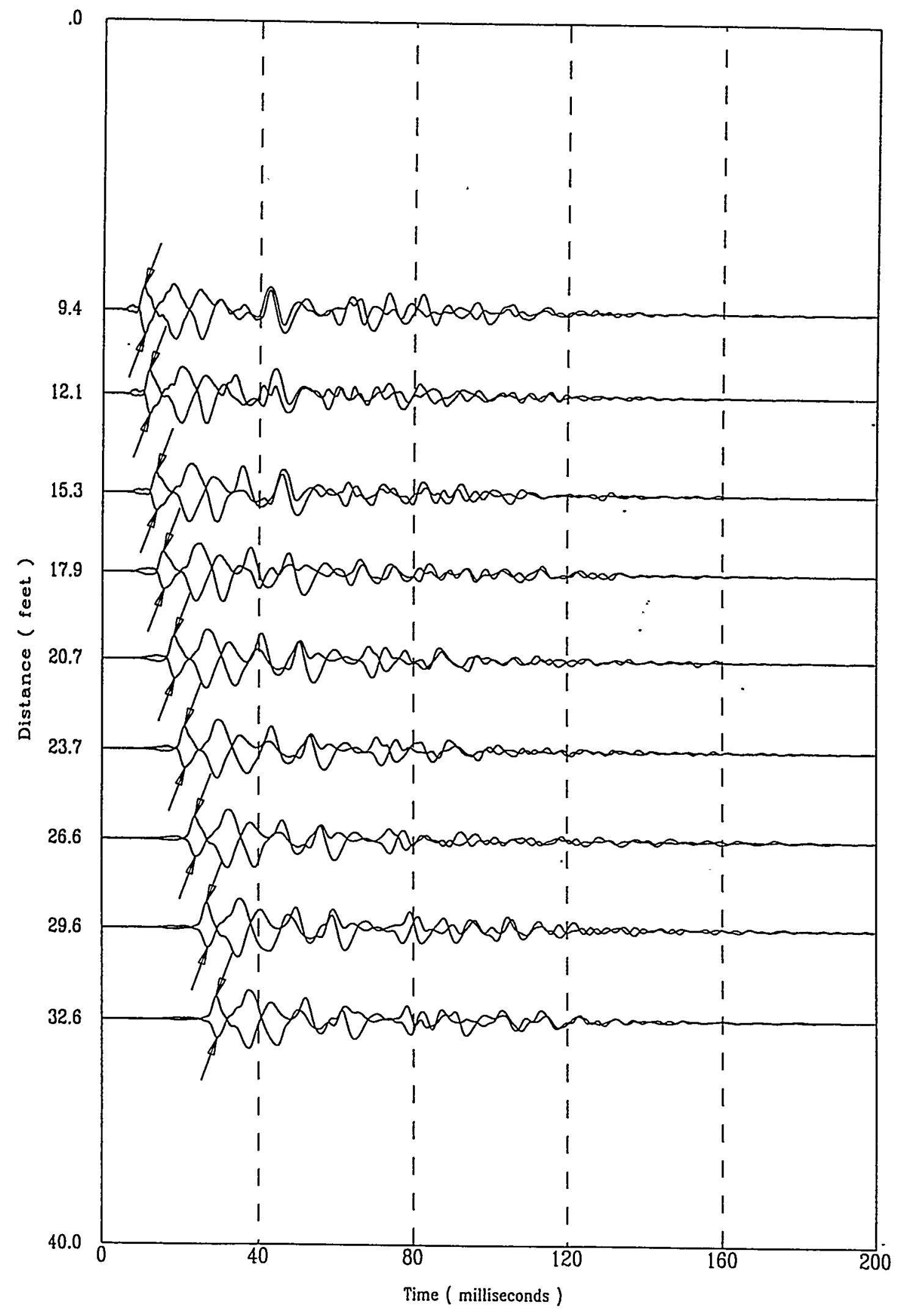


Applied Research Associates

SDFBC15

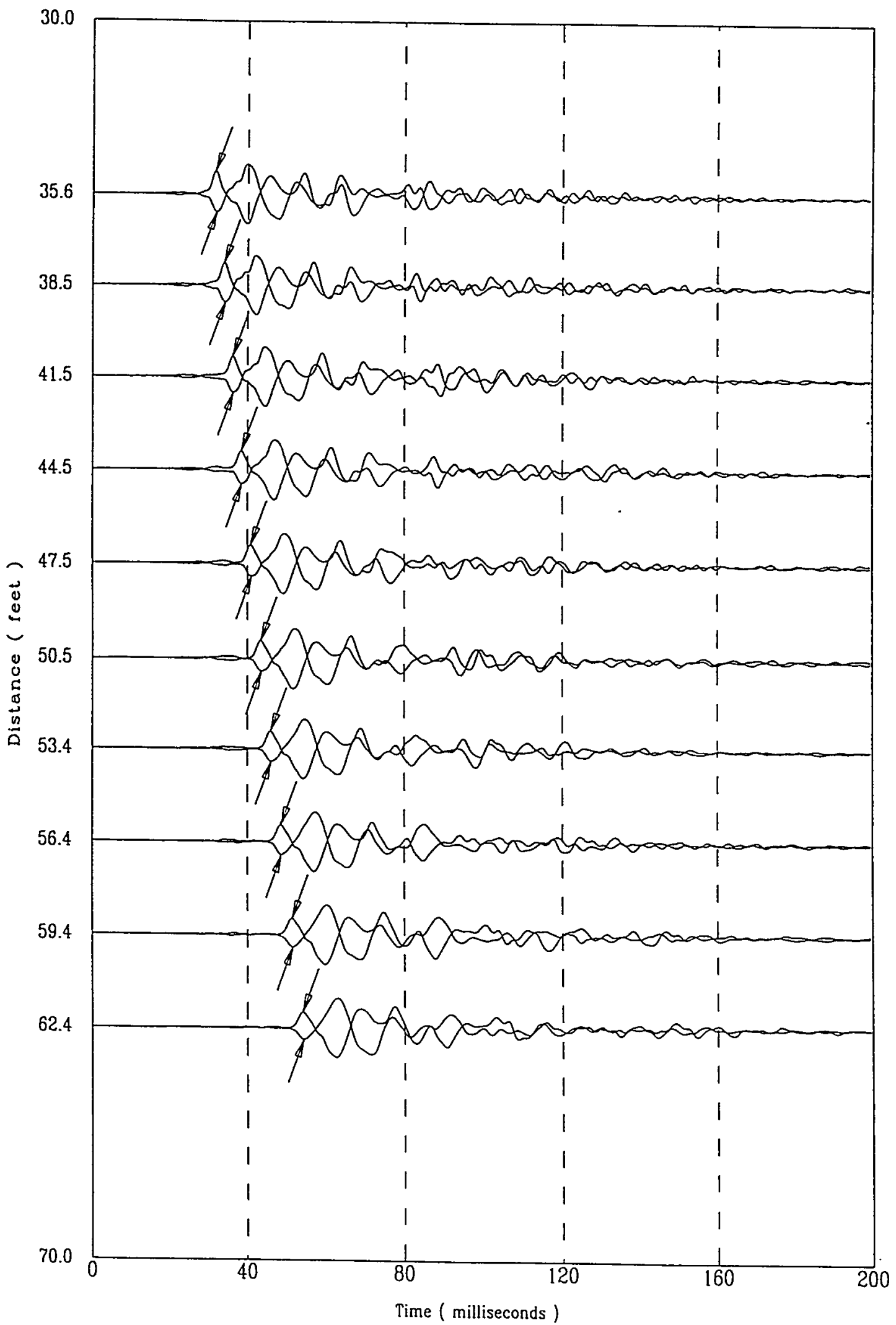


Applied Research Associates

SDFBC15

$S$ Wave

05/07/99

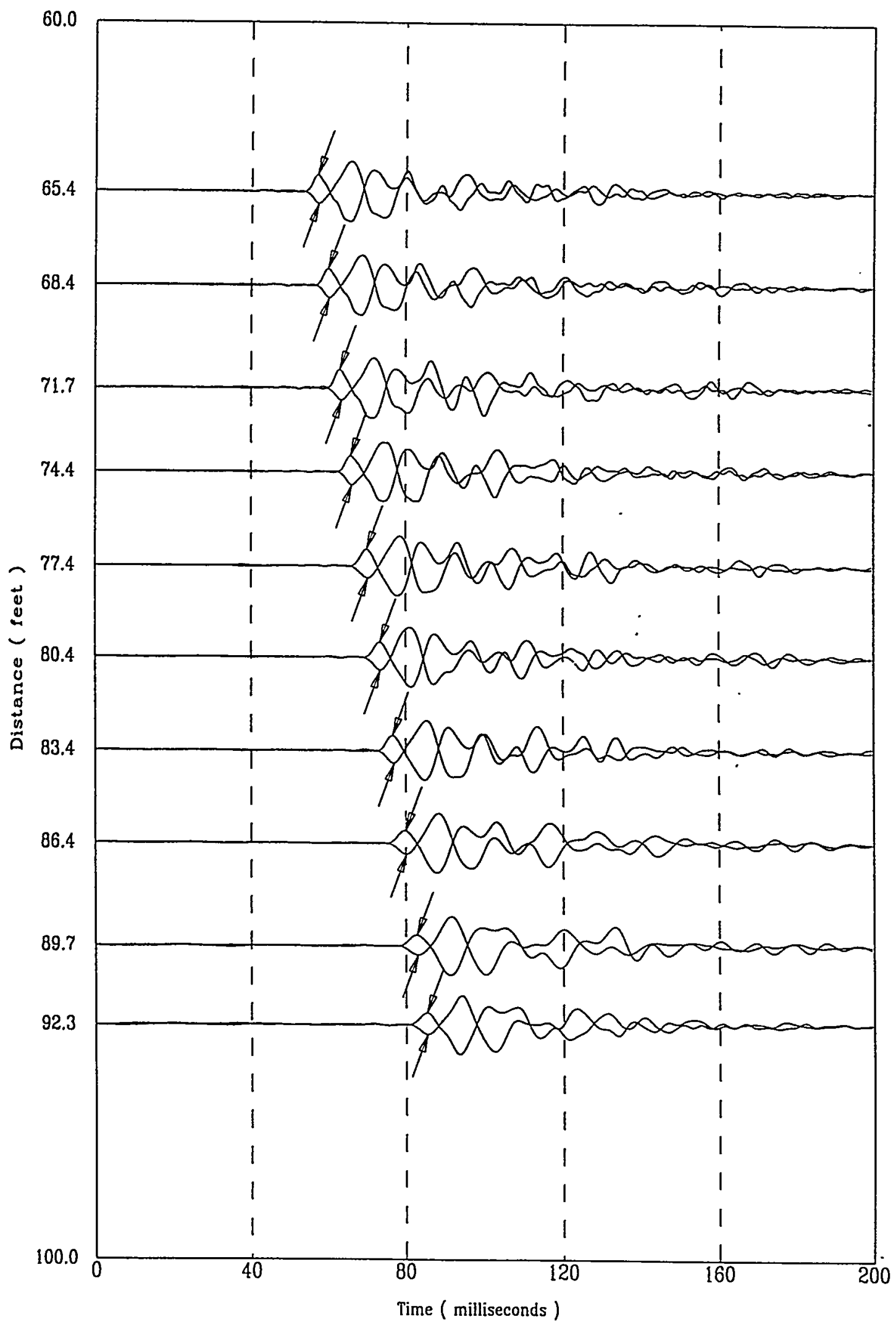


Applied Research Associates SDFBC15
S Wave

05/07/99

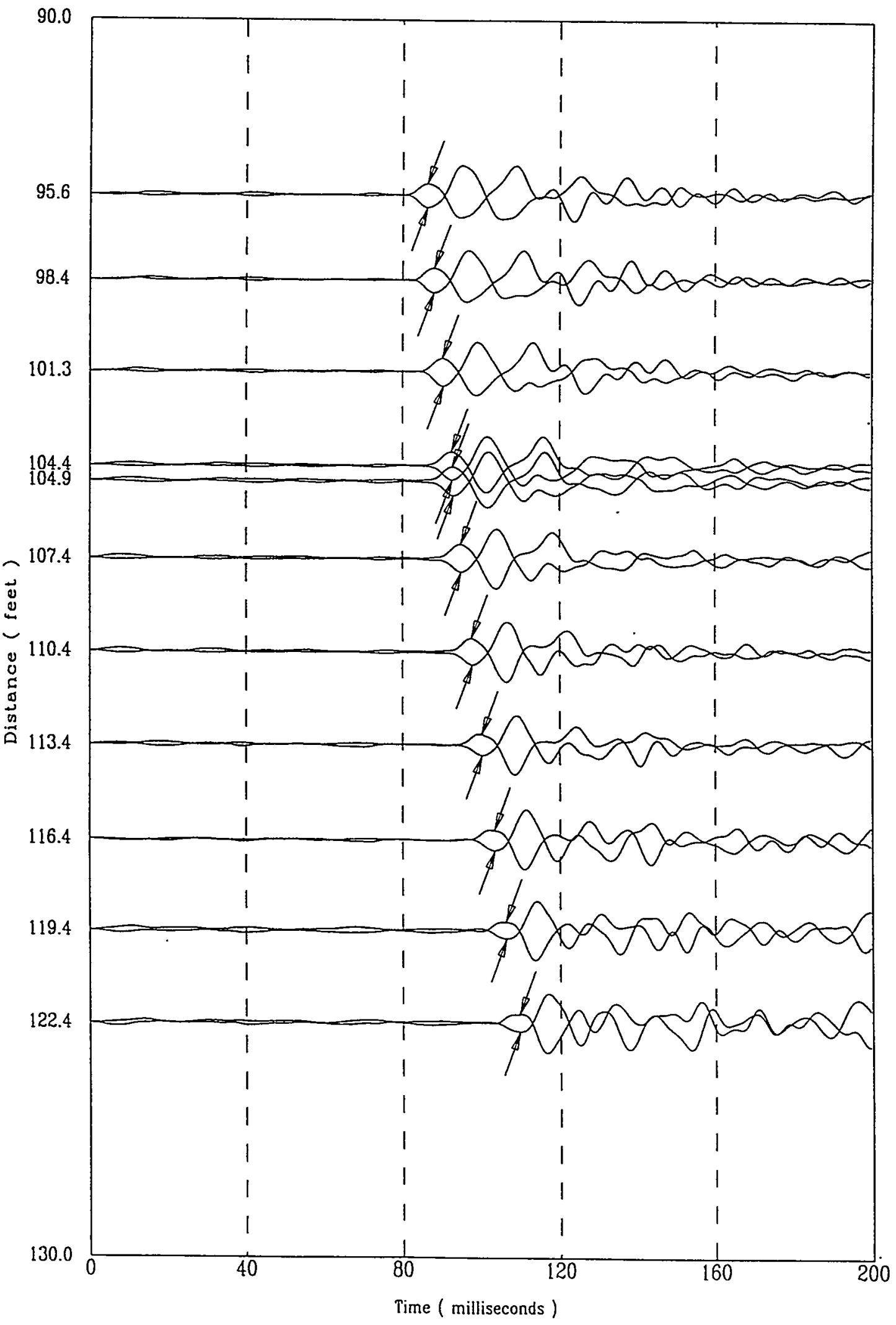


Applied Research Associates SDFBC15
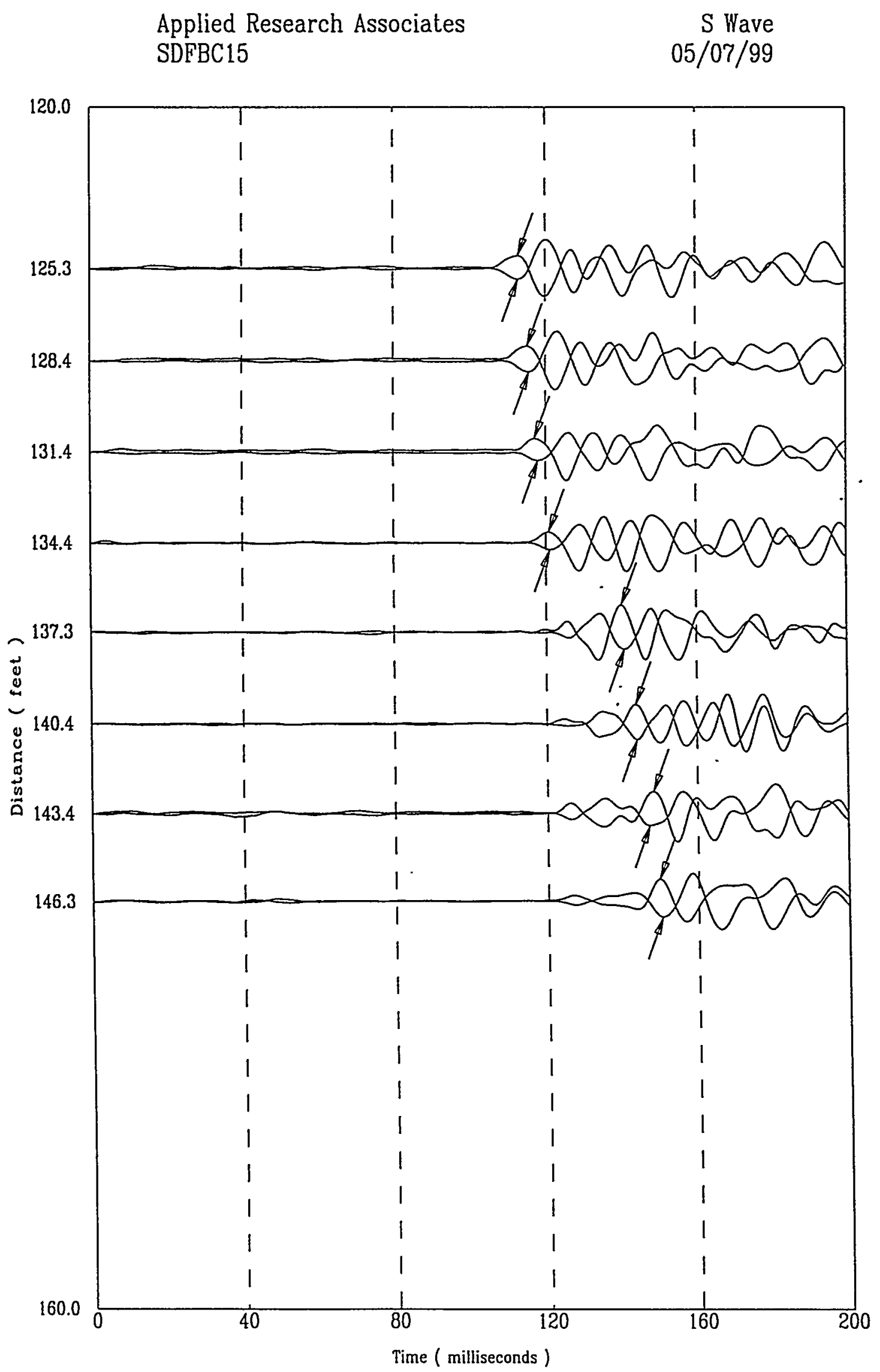
SDFBC15

APPLIED RESEARCH ASSOCIATES, INC. 05/07/99

Compression Wave Speeds

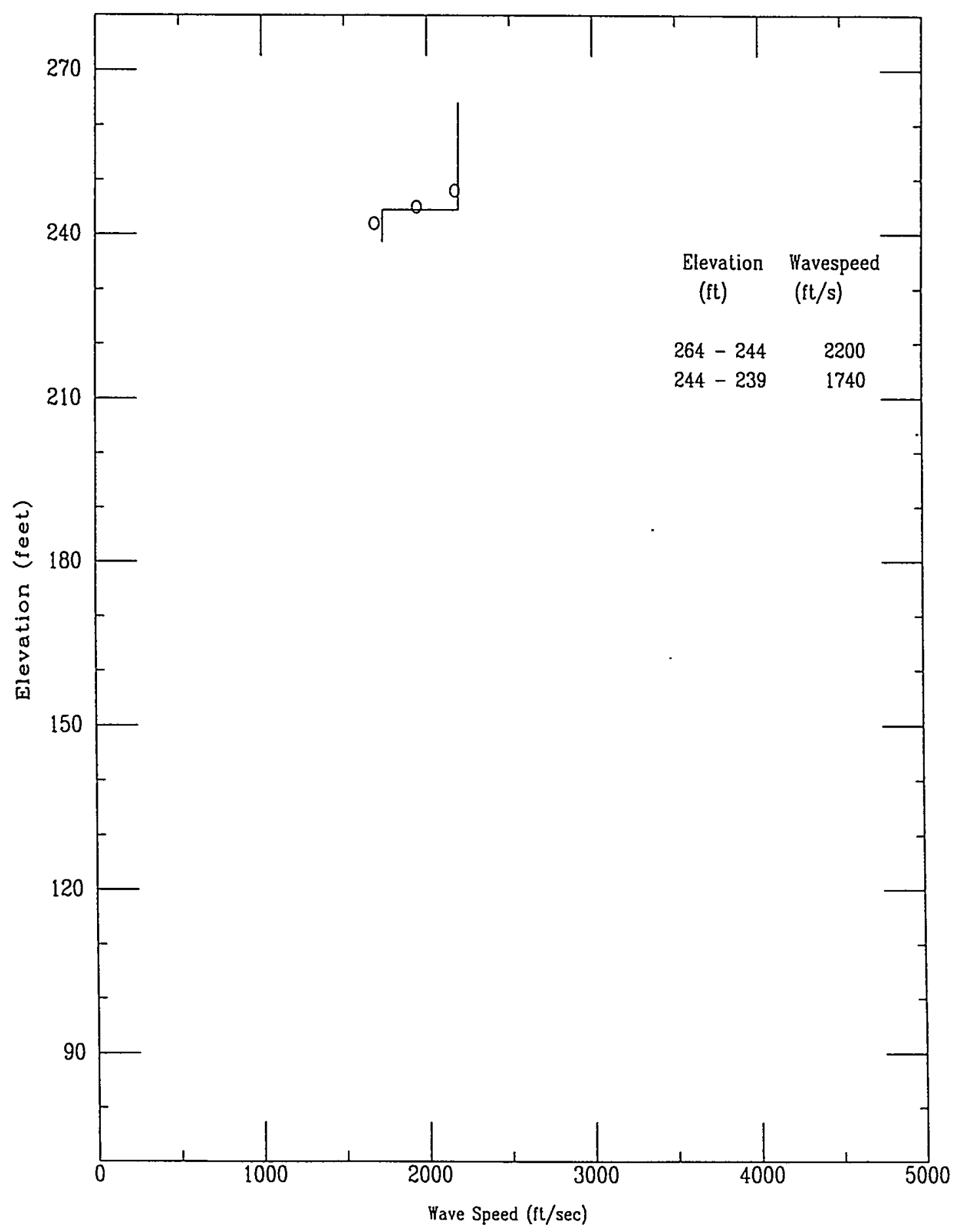

File 307Y901S 


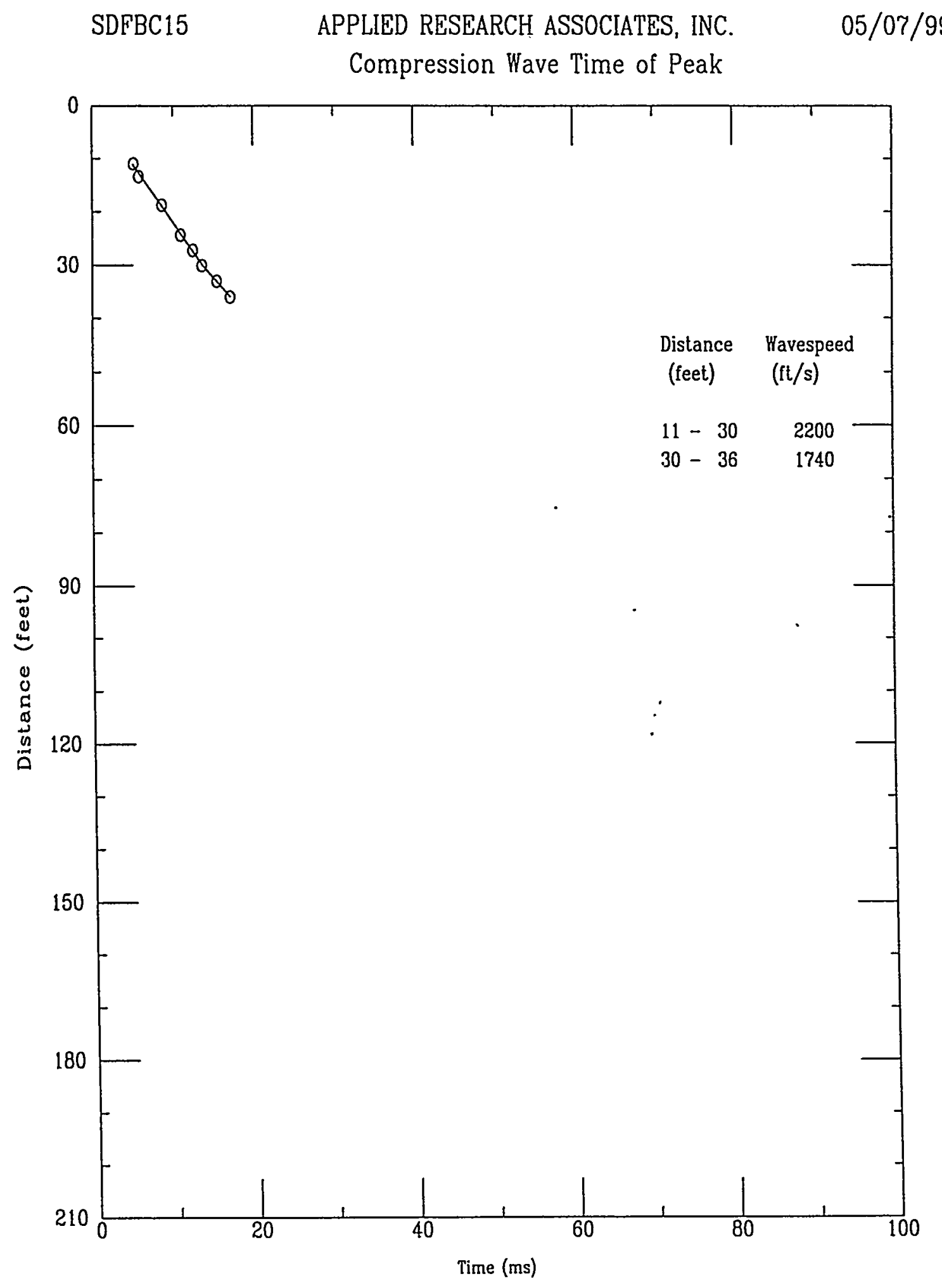

File 307Y901S 
Applied Research Associates

SDFBC14

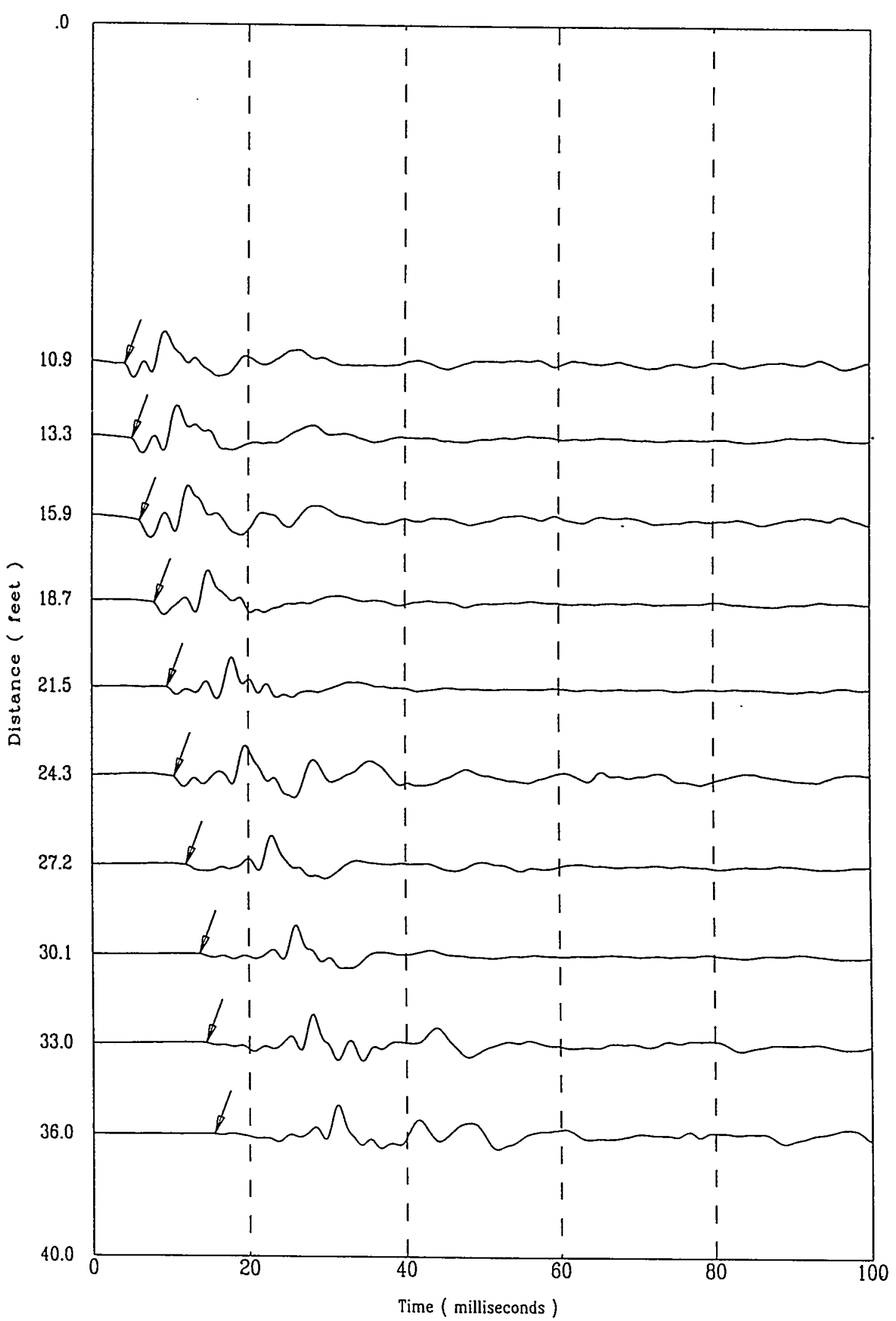

File 310 y901s

Time ( milliseconds ) 
Applied Research Associates

SDFBC15

$\mathrm{P}$ Wave

05/07/99

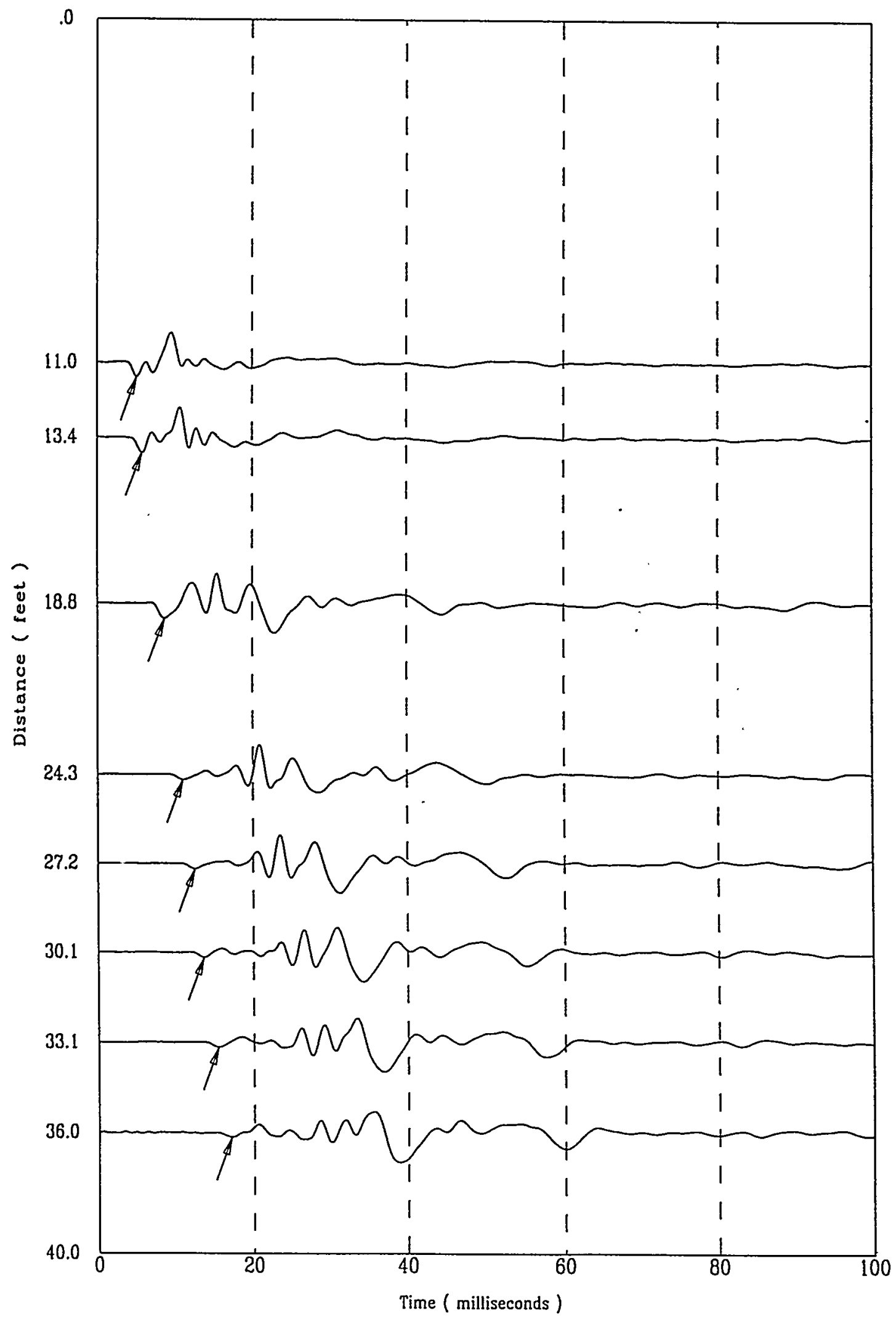


Appendix C

Resistivity Cone Penetrometer Data 
This page intentionally left blank. 


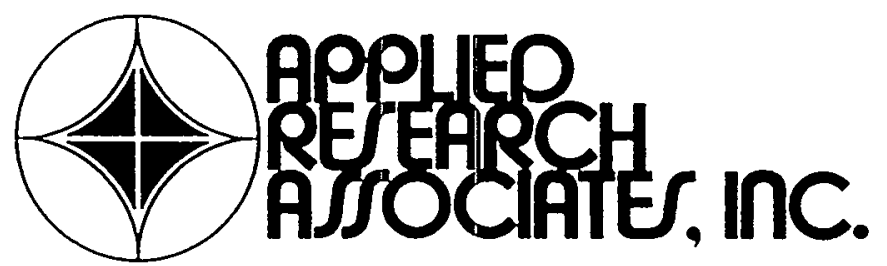

Engineering and Applied Science

June 30, 1999

\author{
L. Bruce Triplett \\ Westinghouse Savannah River Company \\ Building 730-2B, Rm. 1086 \\ Aiken, SC 29808 \\ Dear Mr. Triplett:
}

Attached is the cone penetrometer data from the 10 test locations conducted at the DWPF area of the Savannah River Site, performed under WSRC subcontract AA82276N, task 35. A single water sample was also collected. The cone penetrometer tests conducted and the water sample collected under this task are summarized in Table 1.

The information provided for each cone penetration test includes: corrected tip stress, sleeve stress, friction ratio, pore pressure, soil classification based on friction ratio, and estimated blow counts. Four of the tests contain soil resistivity data and the remaining six test include seismic data. The computer disks provide the ECP and VEL files that contain the plotted data in ASCII format.

The data presented on the attached sheets was obtained and interpreted by qualified ARA personnel in accordance with the requirements of SRS Subcontract No. AA82276N and contained in Specification K-SP-G-00005, Rev. 0. The information contained on the data sheets and computer disks shall be considered as final and correct.

Please feel free to call us if you have any questions regarding the enclosed information.

$$
\begin{aligned}
& \text { Sincerely, } \\
& \text { Dund Q Tin. } \\
& \begin{array}{l}
\text { David A. Timian, P.E. } \\
\text { Principal Engineer }
\end{array}
\end{aligned}
$$

DAT:bef

d:145691Task reports14569_35_itr_rptI.doc 
Table 1 Summary of cone penetrometer tests and water samples at the DWPF area, Task 35

\begin{tabular}{|c|c|c|c|c|c|c|c|c|}
\hline Test ID & Filename & $\begin{array}{c}\text { Type of } \\
\text { Test }\end{array}$ & $\begin{array}{c}\text { Date of } \\
\text { Test }\end{array}$ & $\begin{array}{c}\text { Maximum } \\
\text { Depth } \\
(\mathrm{ft})\end{array}$ & $\begin{array}{c}\text { Northing } \\
(\mathrm{ft})\end{array}$ & $\begin{array}{c}\text { Easting } \\
(\mathrm{ft})\end{array}$ & $\begin{array}{c}\text { Elevation } \\
(\mathrm{ft})\end{array}$ & $\begin{array}{c}\text { G.W.T. } \\
\text { Depth } \\
(\mathrm{ft})\end{array}$ \\
\hline \hline SDFBC4 & $326 a 901$ & S/P-CPT & $4 / 26 / 99$ & 142.0 & 72846.7 & 65251.9 & 278.0 & 37 \\
\hline SDFBC7 & $327 a 901$ & S/P-CPT & $4 / 27 / 99$ & 154.6 & 72703.0 & 65393.4 & 274.0 & 37 \\
\hline SDFBC2 & $327 a 904$ & S/P-CPT & $4 / 27 / 99$ & 130.1 & 72703.0 & 65104.3 & 277.0 & 37 \\
\hline SDFBC10 & $306 y 902$ & S/P-CPT & $5 / 6 / 99$ & 154.0 & 72751.5 & 65251.9 & 277.0 & 47 \\
\hline SDFBC15 & $307 y 901$ & S/P-CPT & $5 / 7 / 99$ & 152.0 & 72768.8 & 65444.7 & 275.0 & 38 \\
\hline SDFBC14 & $310 y 901$ & S/P-CPT & $5 / 10 / 99$ & 147.4 & 72764.3 & 65025.3 & 279.1 & 38 \\
\hline SDFBC5 & $303 y 902$ & R/P-CPT & $5 / 3 / 99$ & 151.8 & 72703.0 & 65251.0 & 276.0 & 43 \\
\hline SDFBC3 & $303 y 904$ & R/P-CPT & $5 / 3 / 99$ & 151.5 & 72751.3 & 65326.4 & 276.0 & 38 \\
\hline SDFBC6 & $303 y 906$ & R/P-CPT & $5 / 3 / 99$ & 149.0 & 72846.7 & 65393.4 & 277.0 & 38 \\
\hline SDFBC1 & $304 y 901$ & R/P-CPT & $5 / 4 / 99$ & 156.7 & 72846.0 & 65094.0 & 280.0 & 46 \\
\hline SDFBB1 & & WS & $5 / 10 / 99$ & 45.0 & & & & \\
\hline
\end{tabular}


$\begin{array}{cccc}\text { SDFBC1 } & \text { APPLIED RESEARCH ASSOCIATES, INC. } & \text { 05/04/99 } \\ \text { North 72846.0 } & \text { East } 65094.0 & \text { Elevation } 280.0\end{array}$
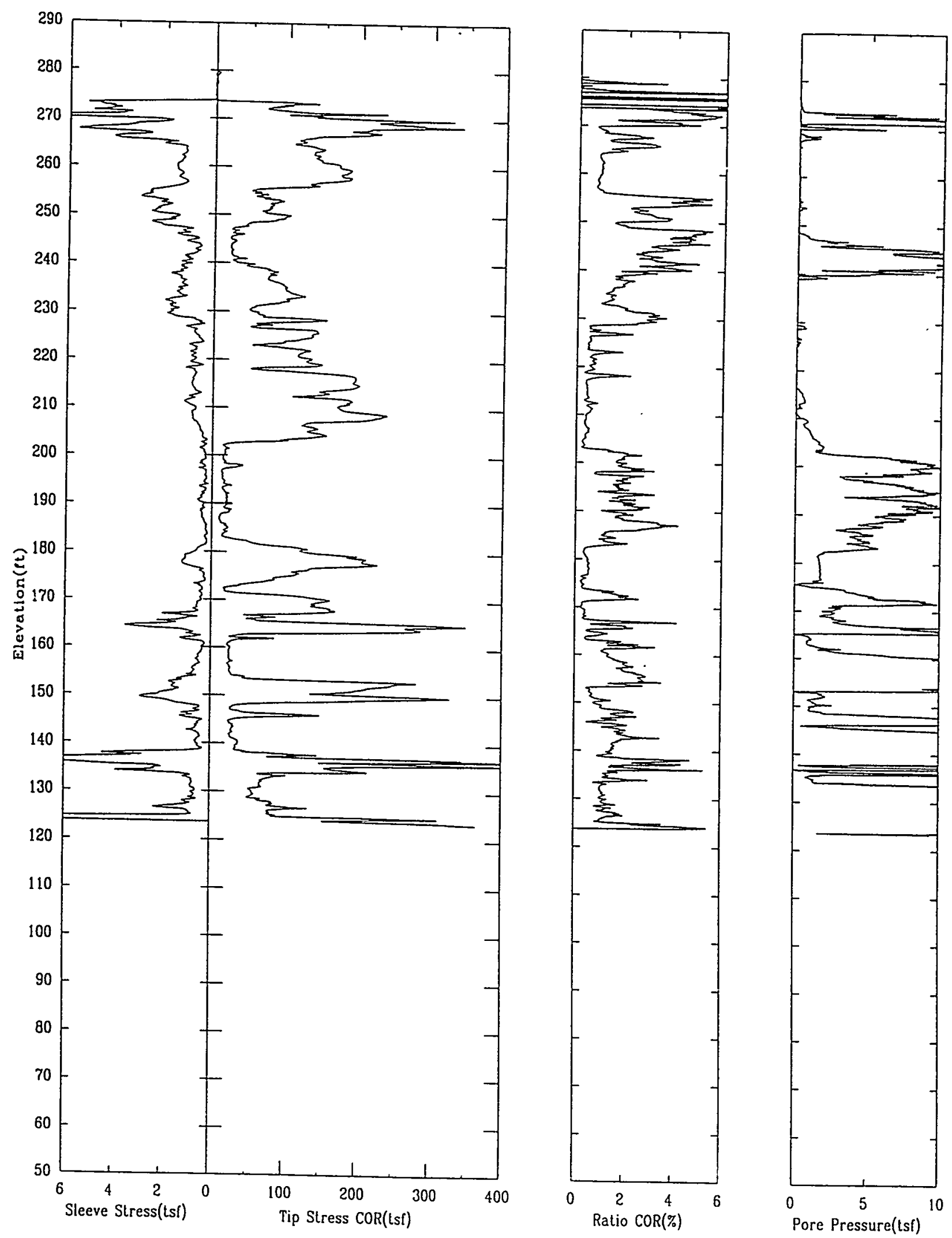
SDFBC1 APPLIED RESEARCH ASSOCIATES, INC.

$05 / 04 / 99$

North 72846.0 East $65094.0 \quad$ Elevation 280.0
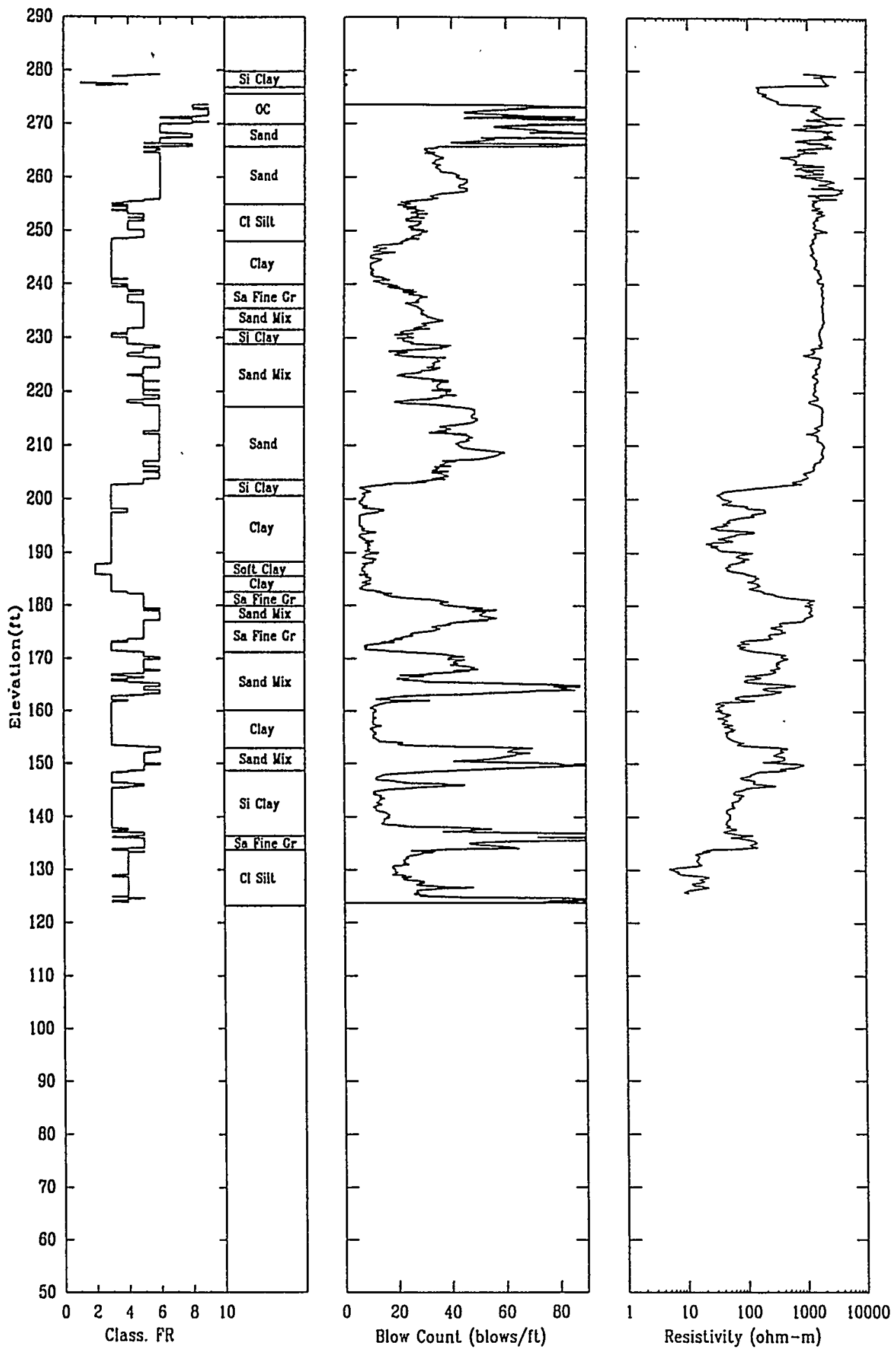
SDFBC3 APPLIED RESEARCH ASSOCIATES, INC.

$05 / 03 / 99$

North 72751.3 East 65326.4 Elevation 276.0
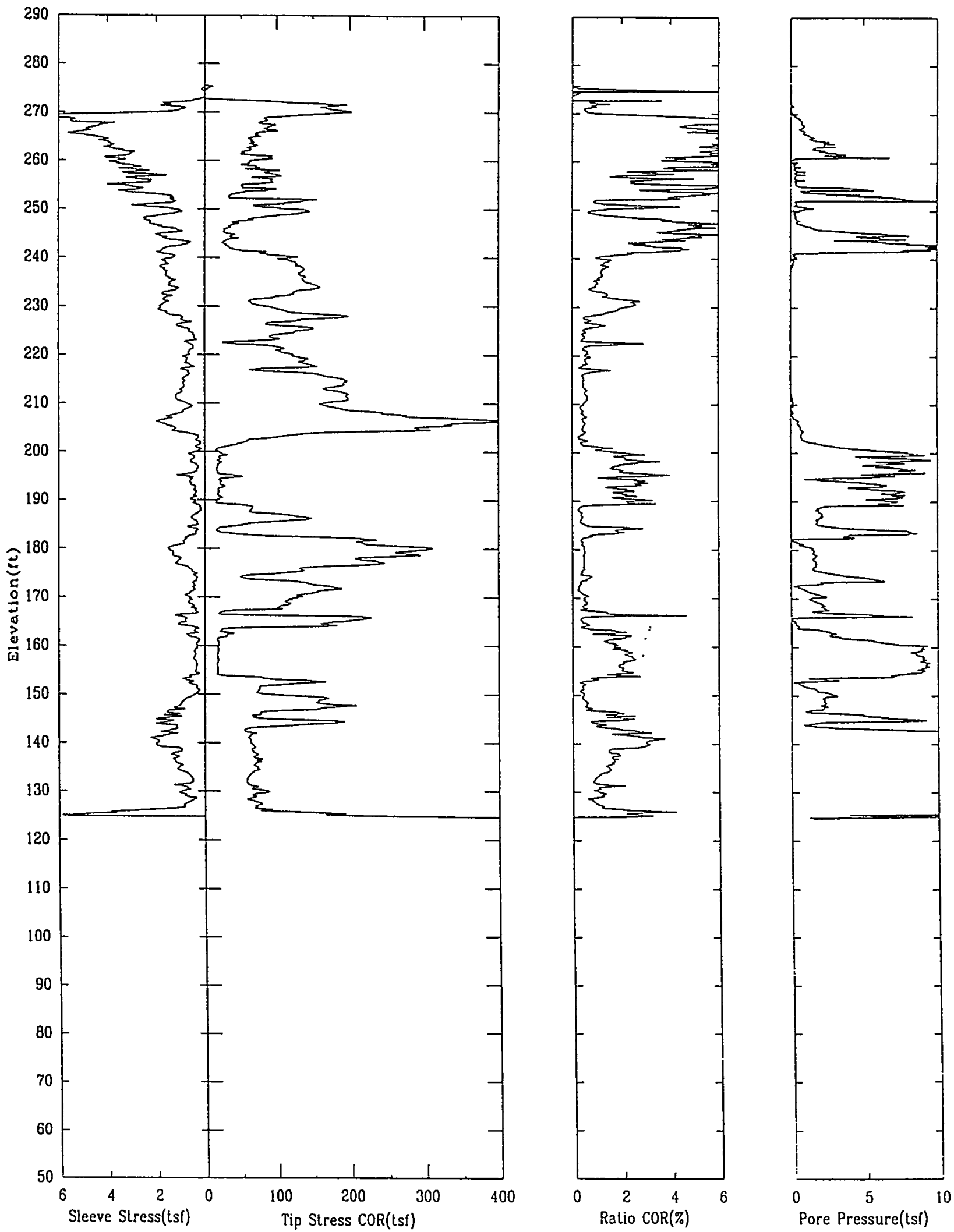
SDFBC3

APPLIED RESEARCH ASSOCIATES, INC.

$05 / 03 / 99$

North 72751.3 East 65326.4. Elevation 276.0
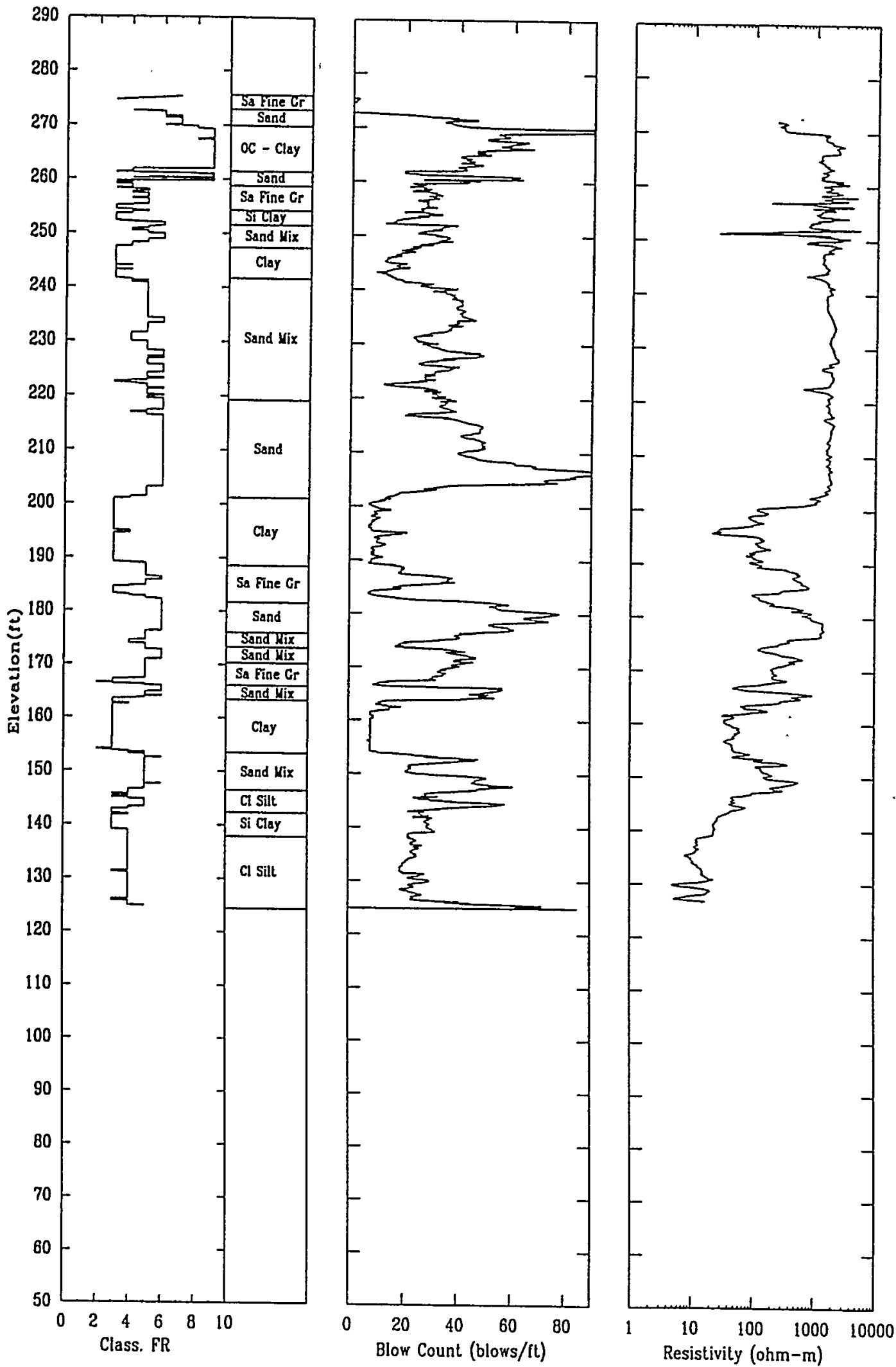

File 303y904.ECP 


\section{North 72703.0 East 65251.0 Elevation 276.0}
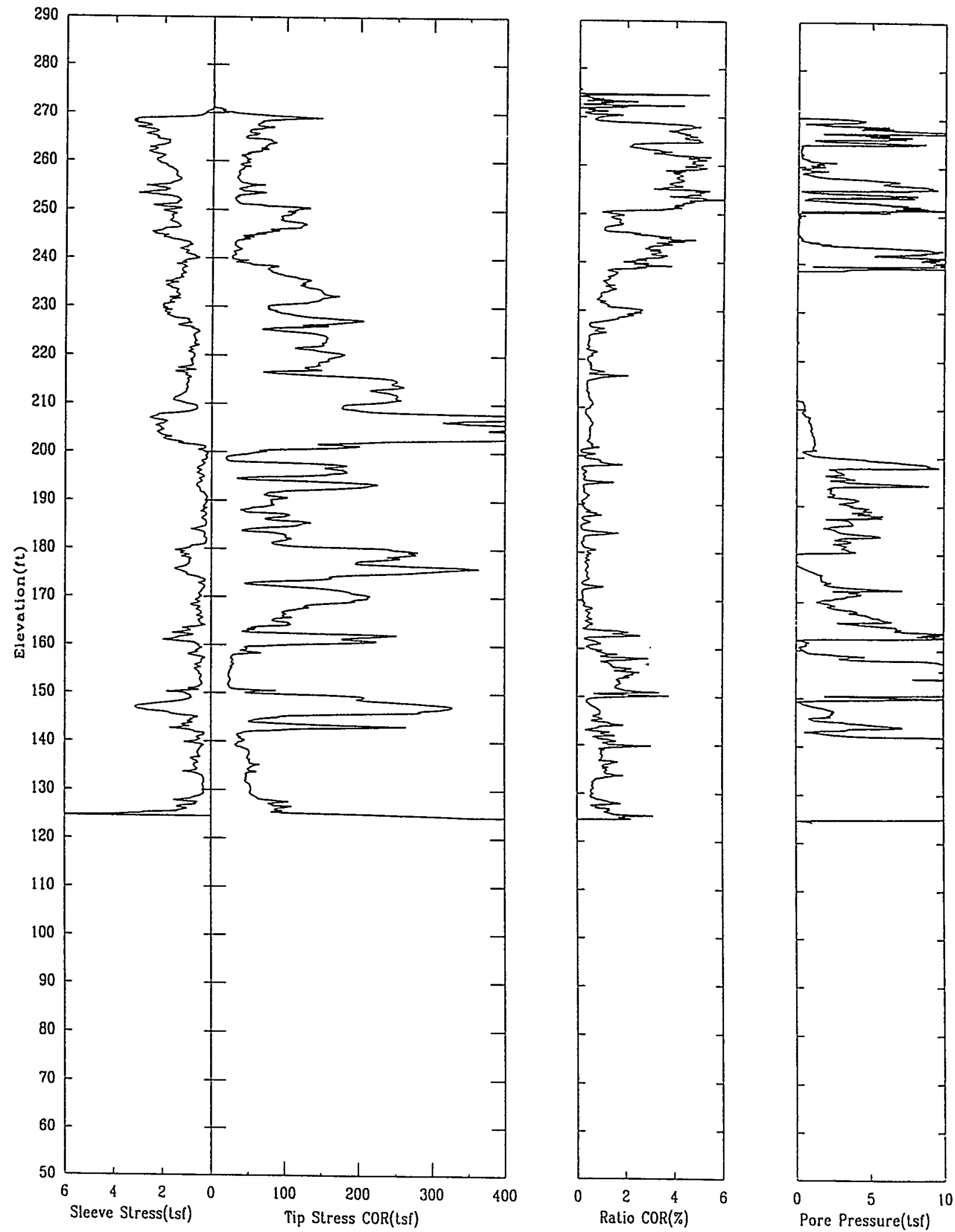


\section{North 72703.0 East 65251.0 Elevation 276.0}
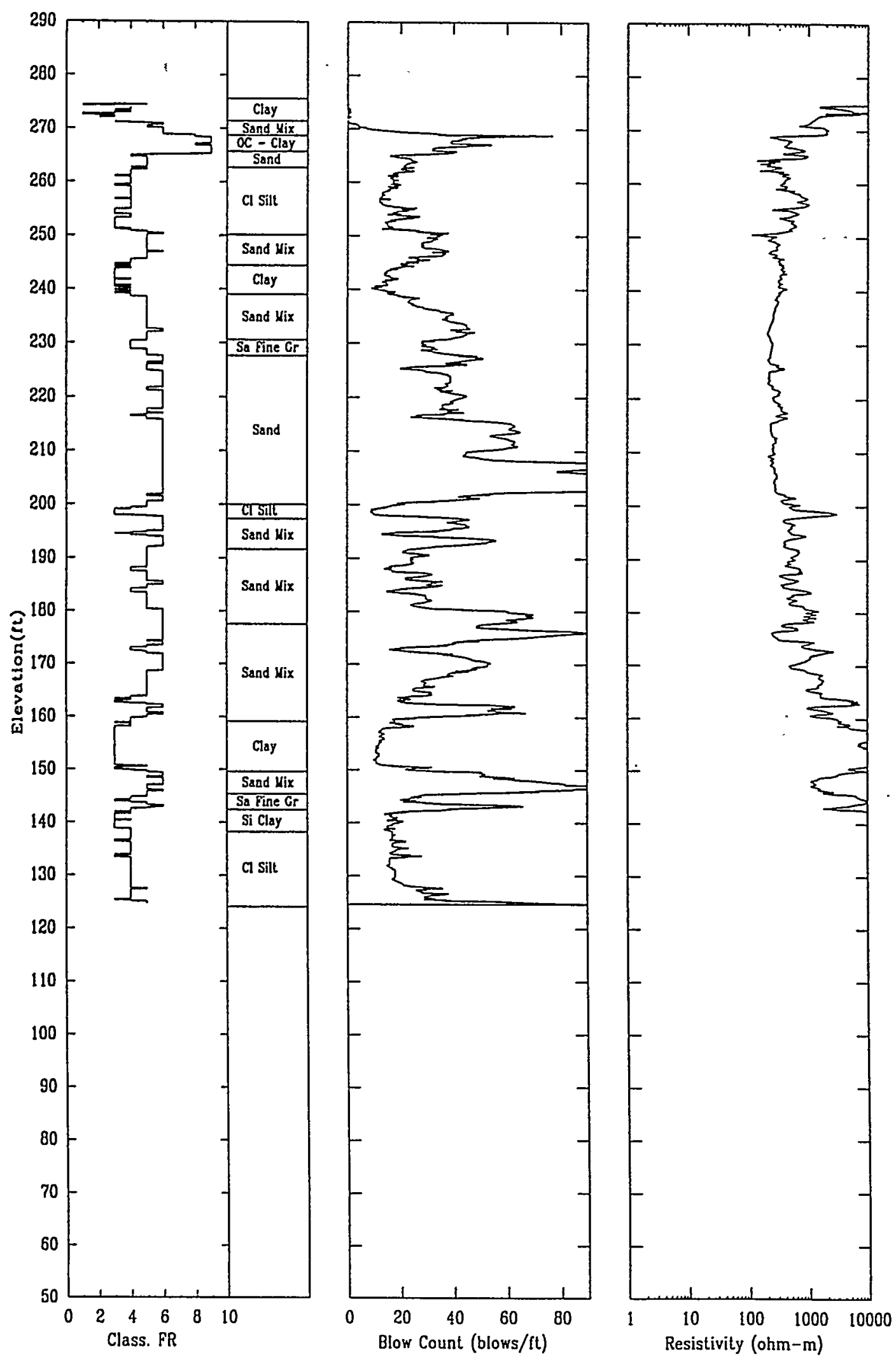
SDFBC6 APPLIED RESEARCH ASSOCIATES, INC. 05/03/99 North 72846.7 East 65393.4 Elevation 277.0
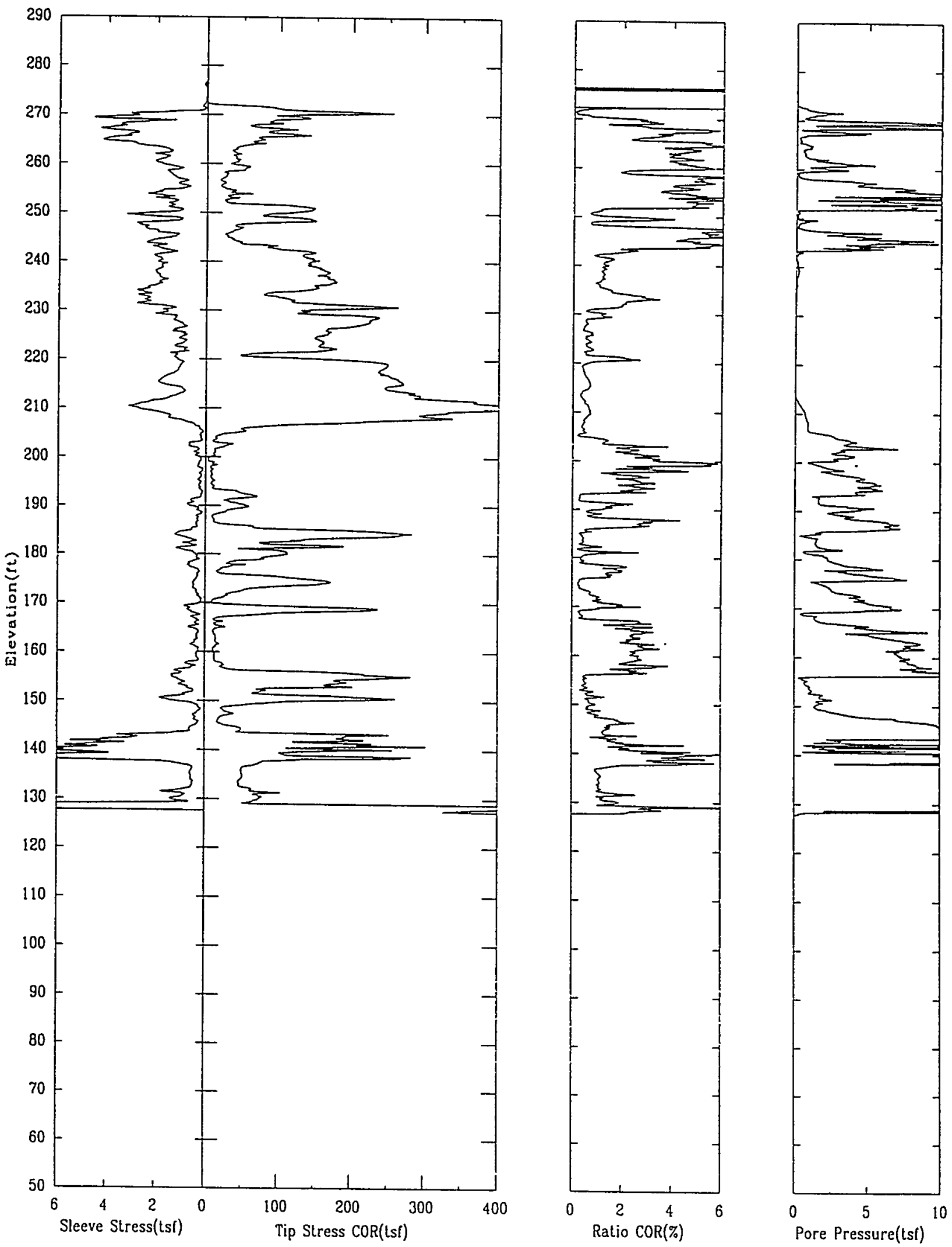
$\begin{array}{cccc}\text { SDFBC6 } & \text { APPLIED RESEARCH ASSOCIATES, INC. } & \text { 05/03/99 } \\ \text { North } 72846.7 & \text { East } 65393.4 & \text { Elevation } 277.0\end{array}$
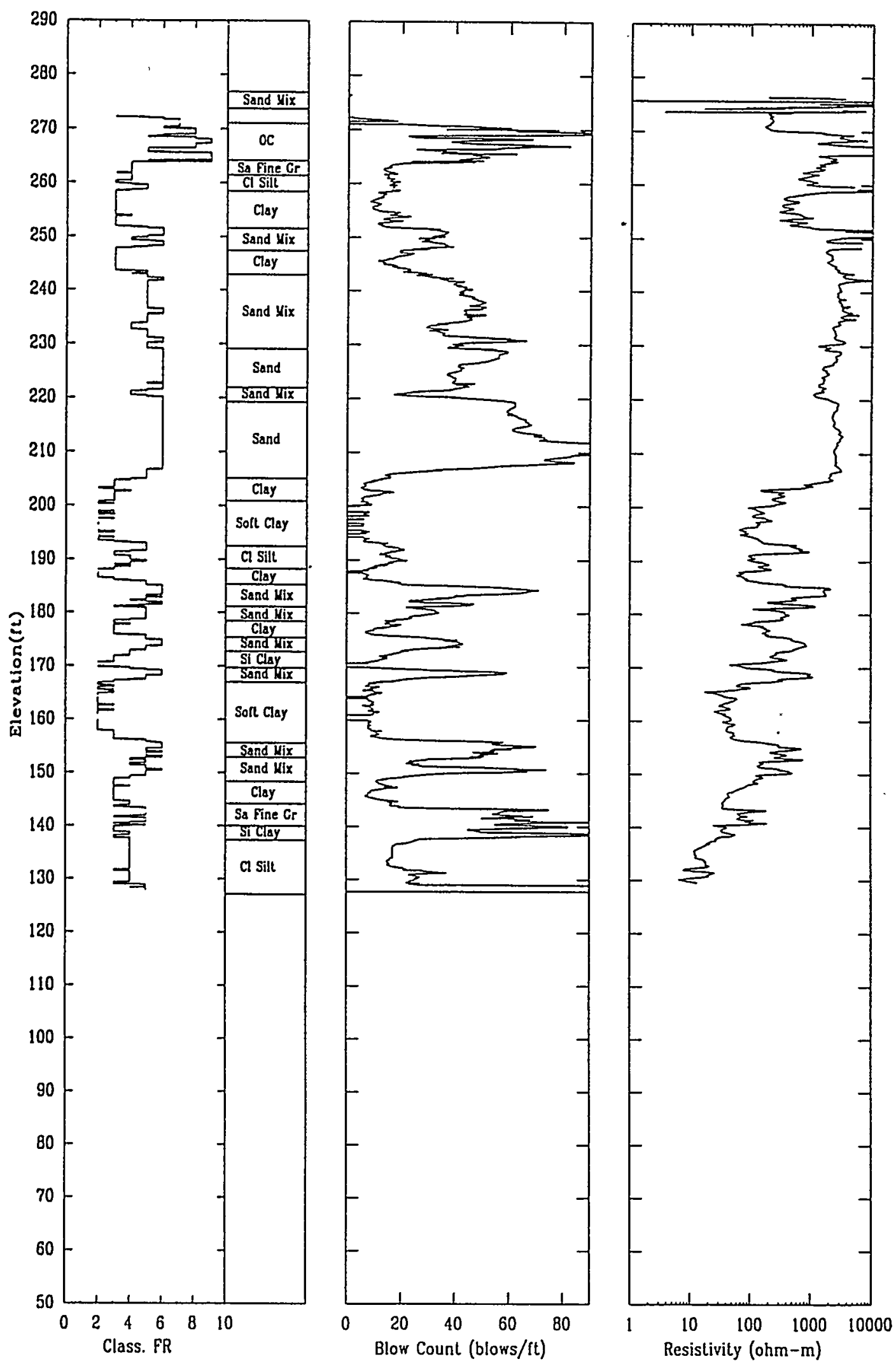
Appendix D

Sediment Laboratory Results 
This page intentionally left blank. 


\section{LAW \\ LAWGIBB Group Member}

June 16,1999

Westinghouse Savannah River Company

P.O. Box 616

Aiken, South Carolina 29808

Attention: $\quad$ Mr. Bruce Triplett

Building 730-2B, Room 1086

Subcontract No. AB80111N

Subject:Transmittal of Test Results: Salt Disposition Facility Investigation

Geotechnical Testing Services

WSRC Site Wide - Task Release No.40

Dear Mr. Triplett:

Law Engineering Project No. 50161-7-0108 (Phase 40)

Law Engineering and Environmental Services, Inc. has completed the assigned laboratory tests for Task Release No. 40 of our 3-year site-wide geotechnical testing contract. We are transmitting to you the tabular and/or graphical summary for each of the specimens tested. A copy of the Laboratory Assignment Sheet is enclosed with the samples tested These are the final results, thus, we have enclosed two copies of the following test results for your distribution:

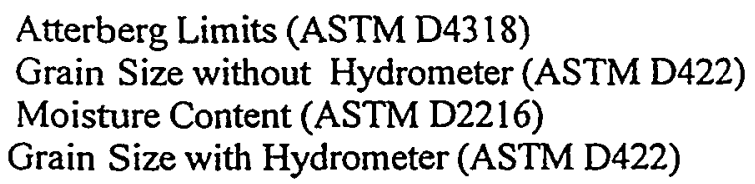

If you have any questions pertaining to these test results or require additional information, please do not hesitate to call us.

Sincerely,

LAW ENGINEERING and ENVIRONMENTAL SERVICES, INC.

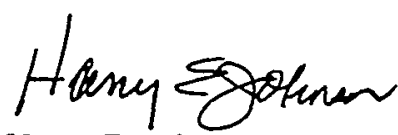

Harry E. Johnson.

Principal Technician 


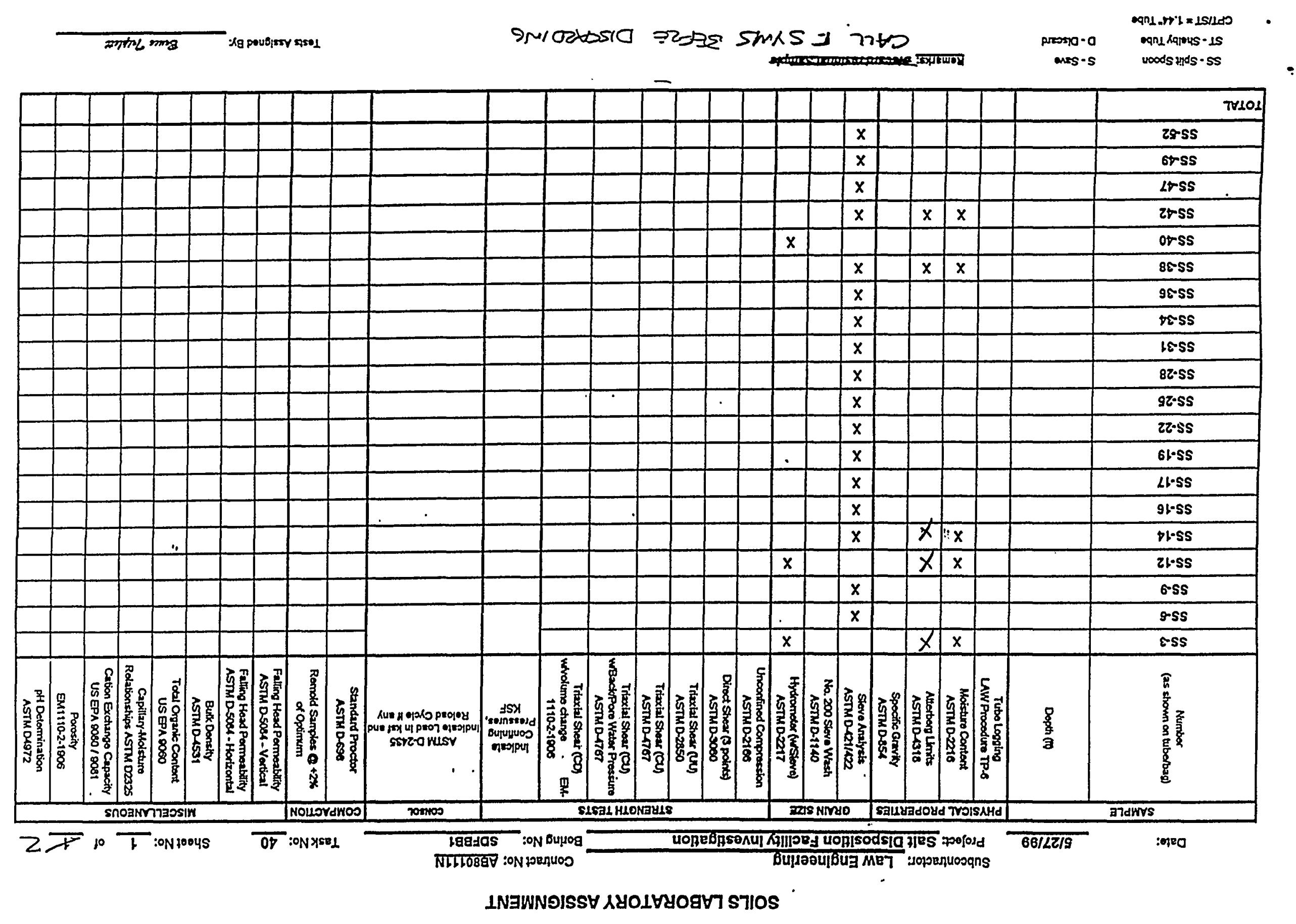




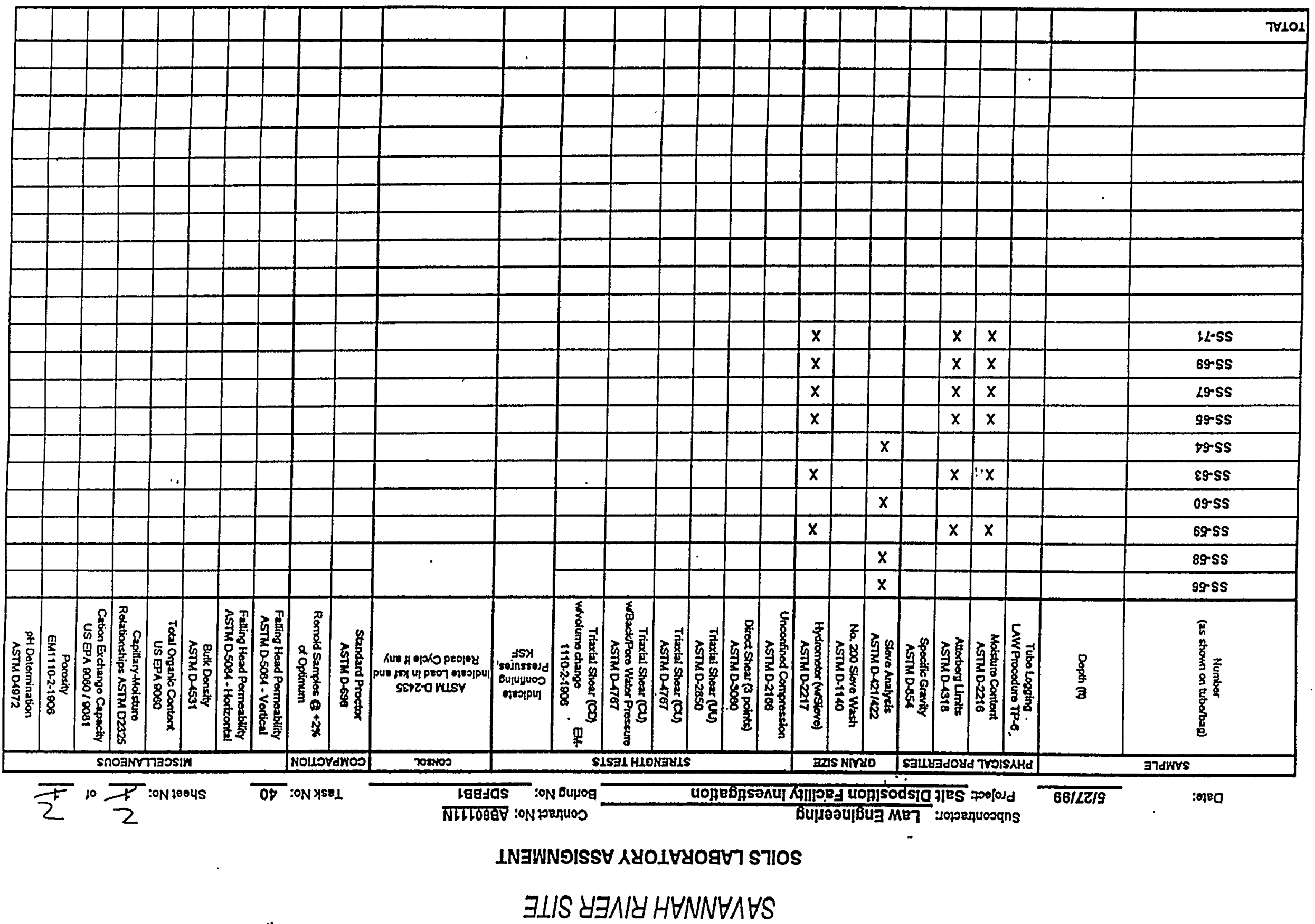




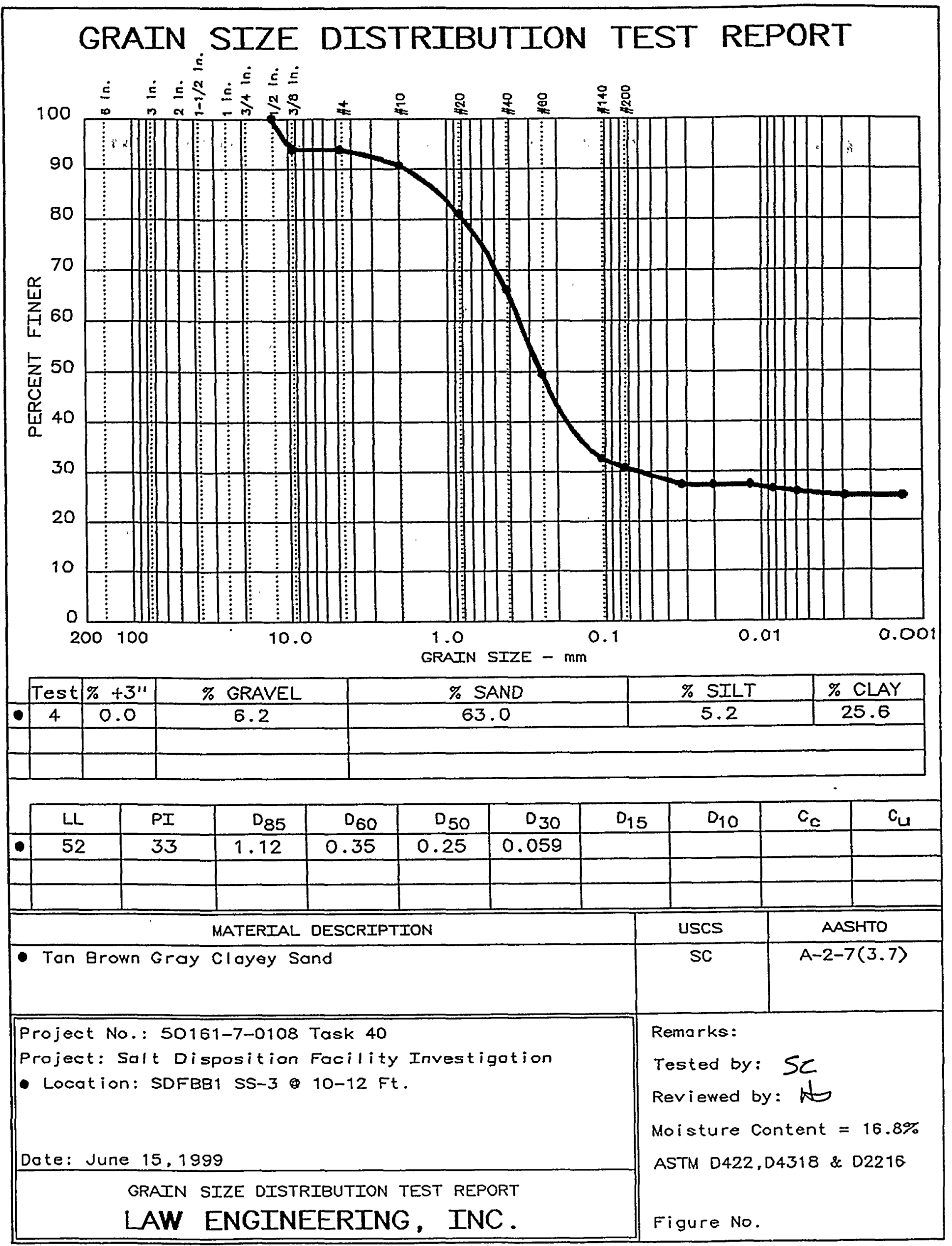




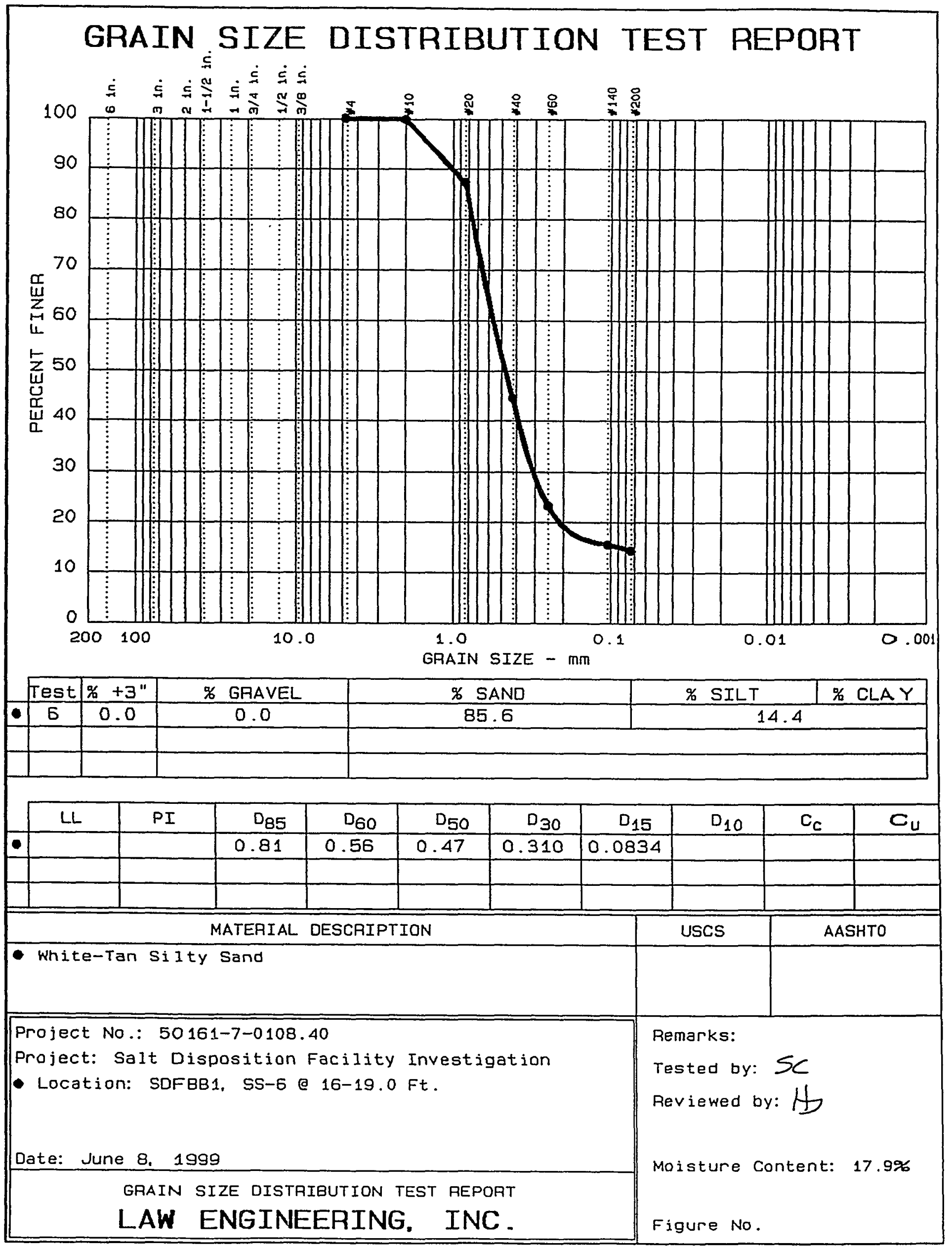




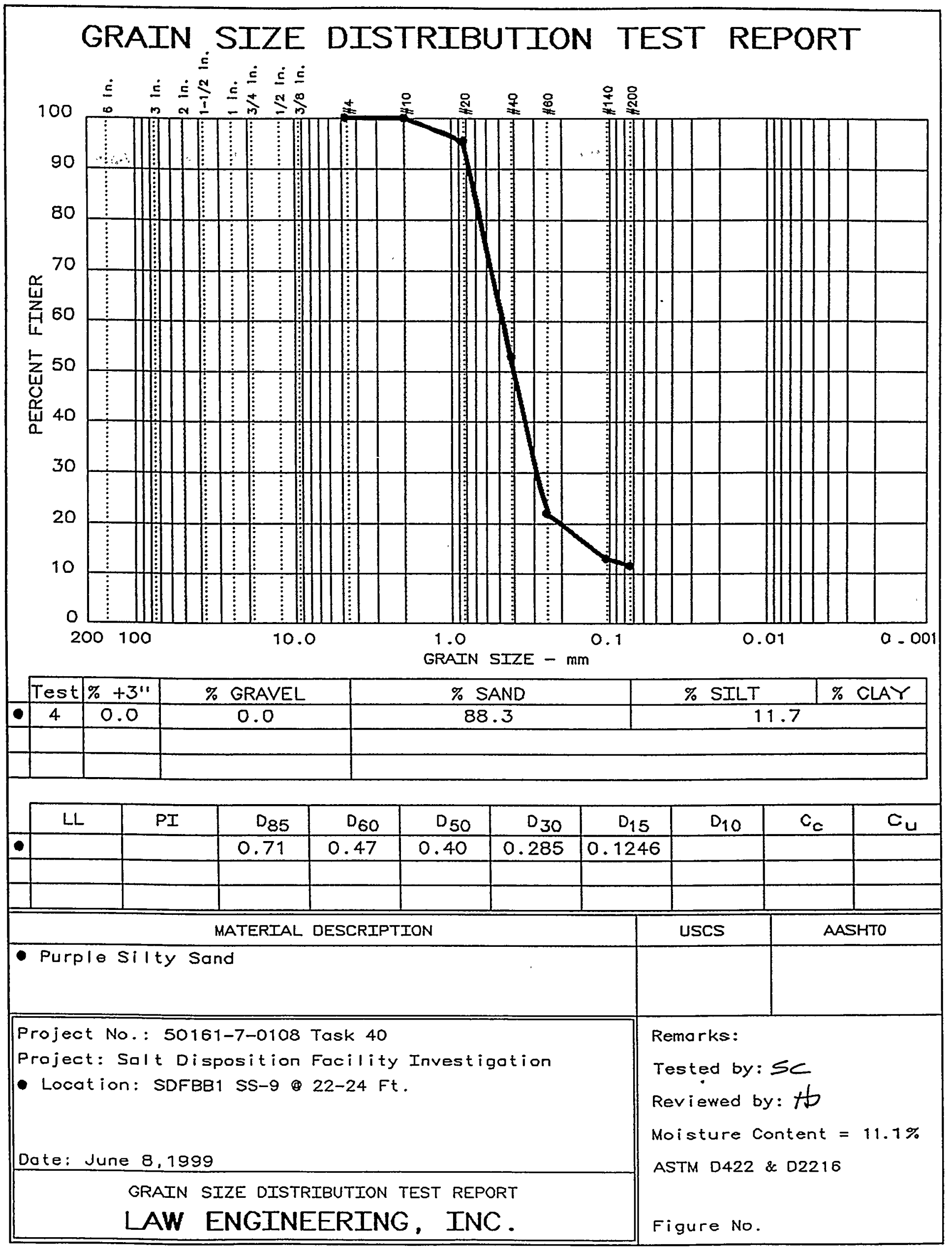




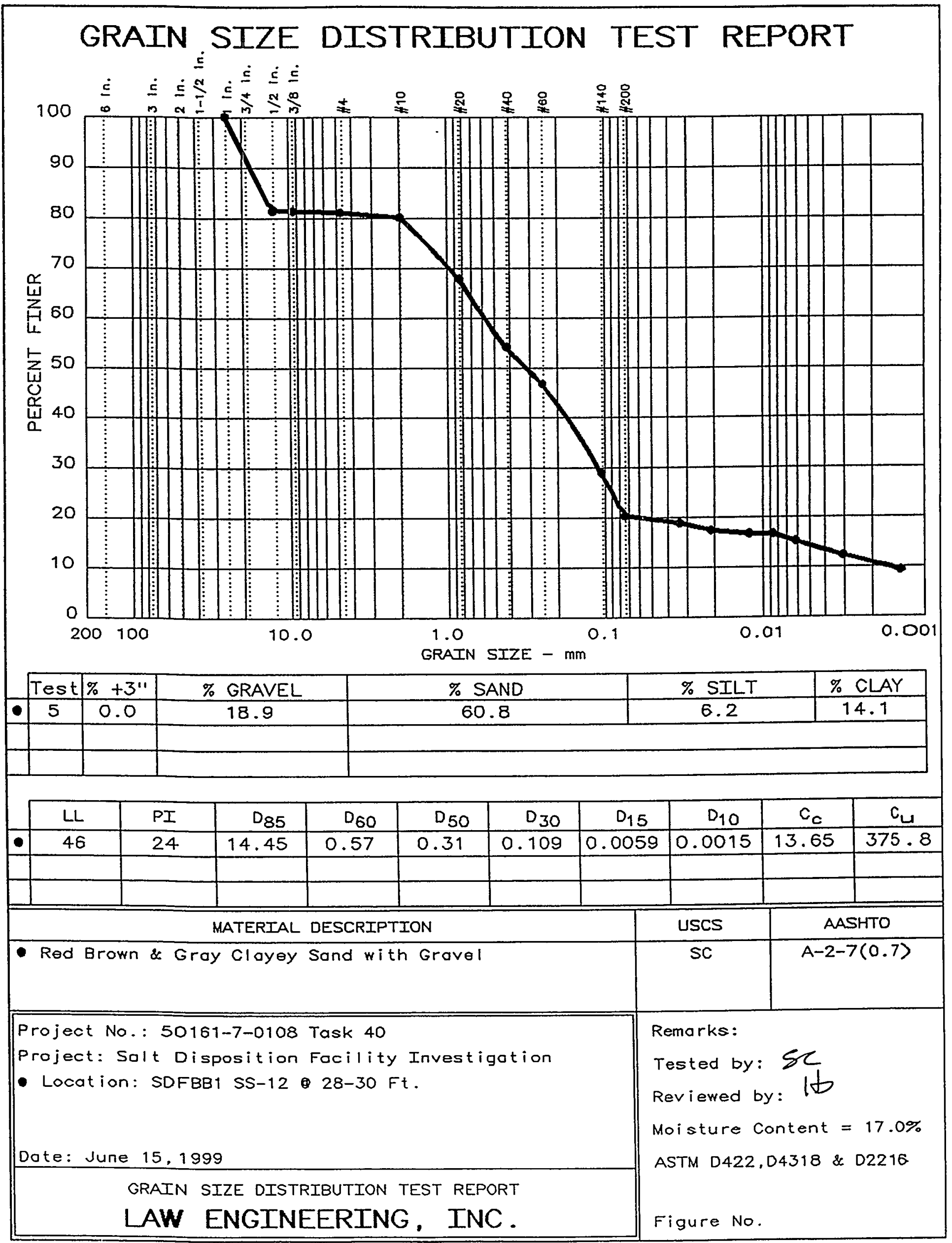




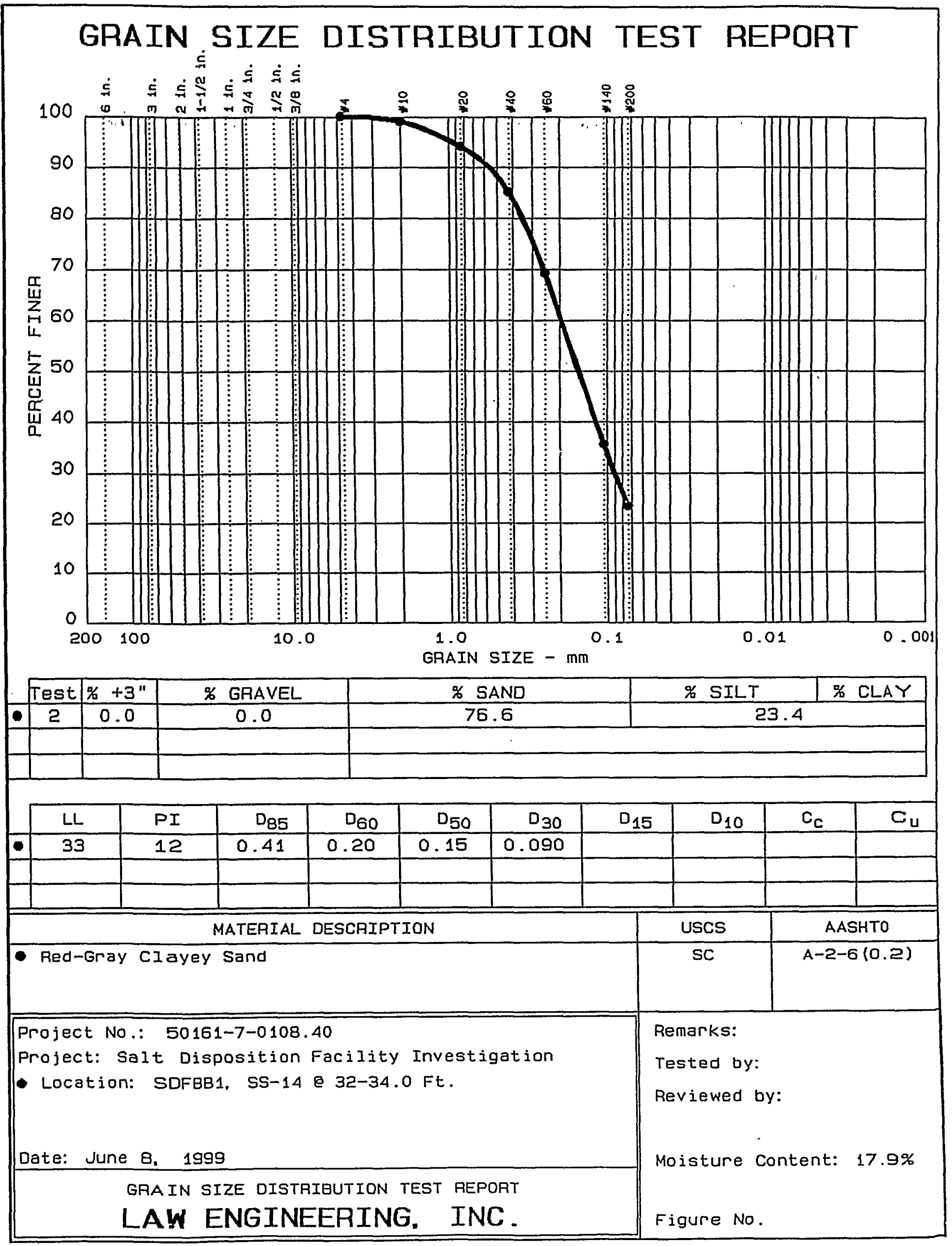




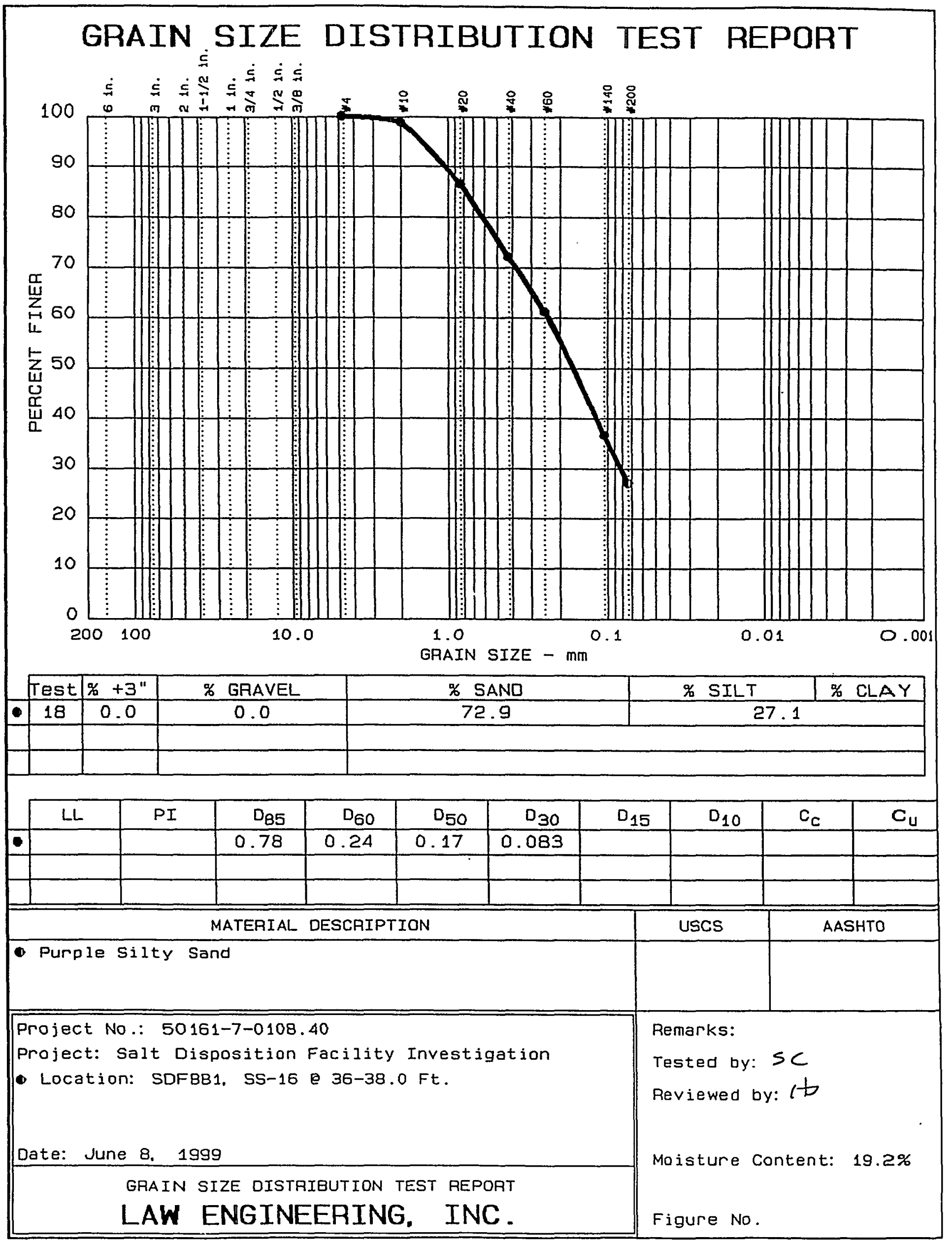




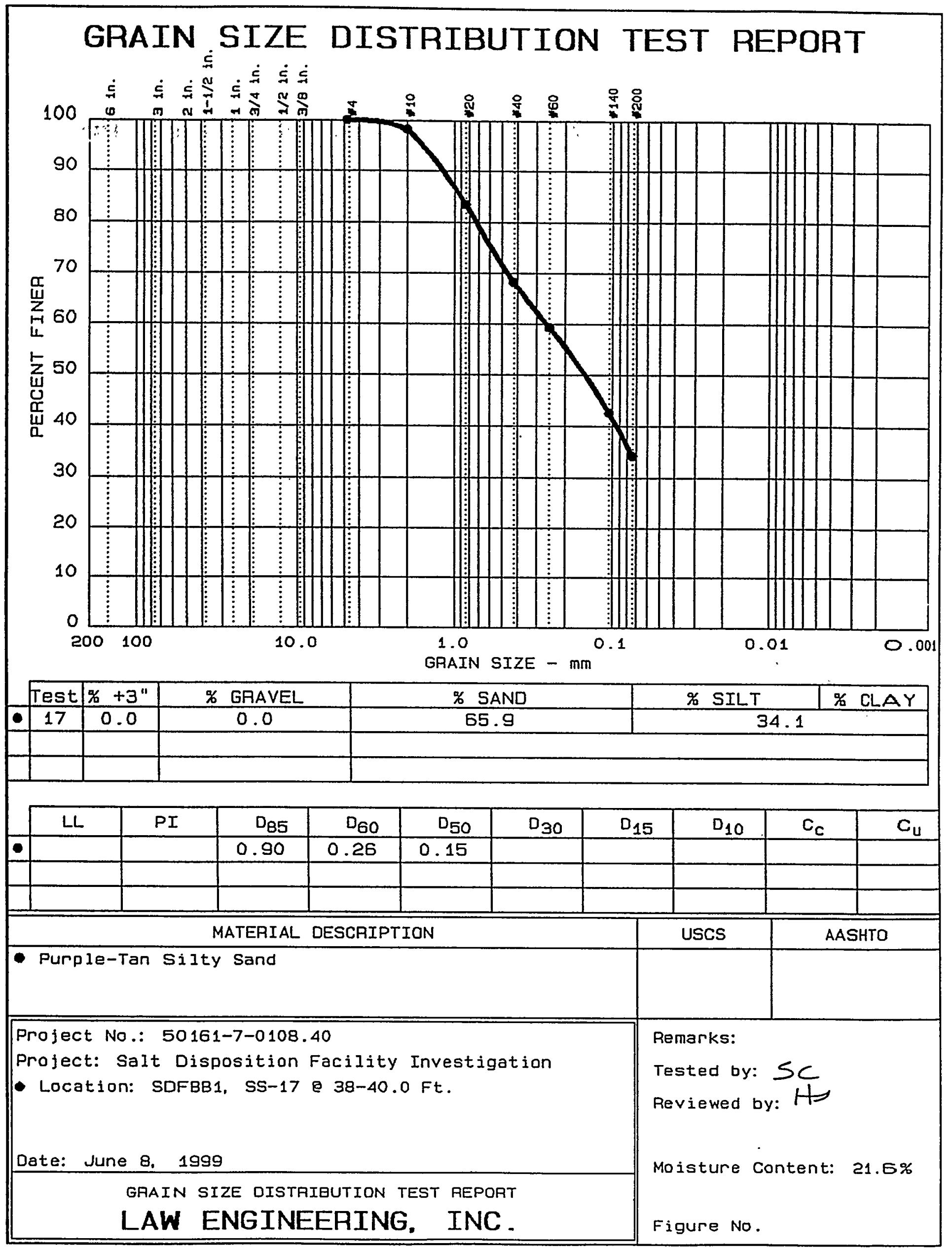




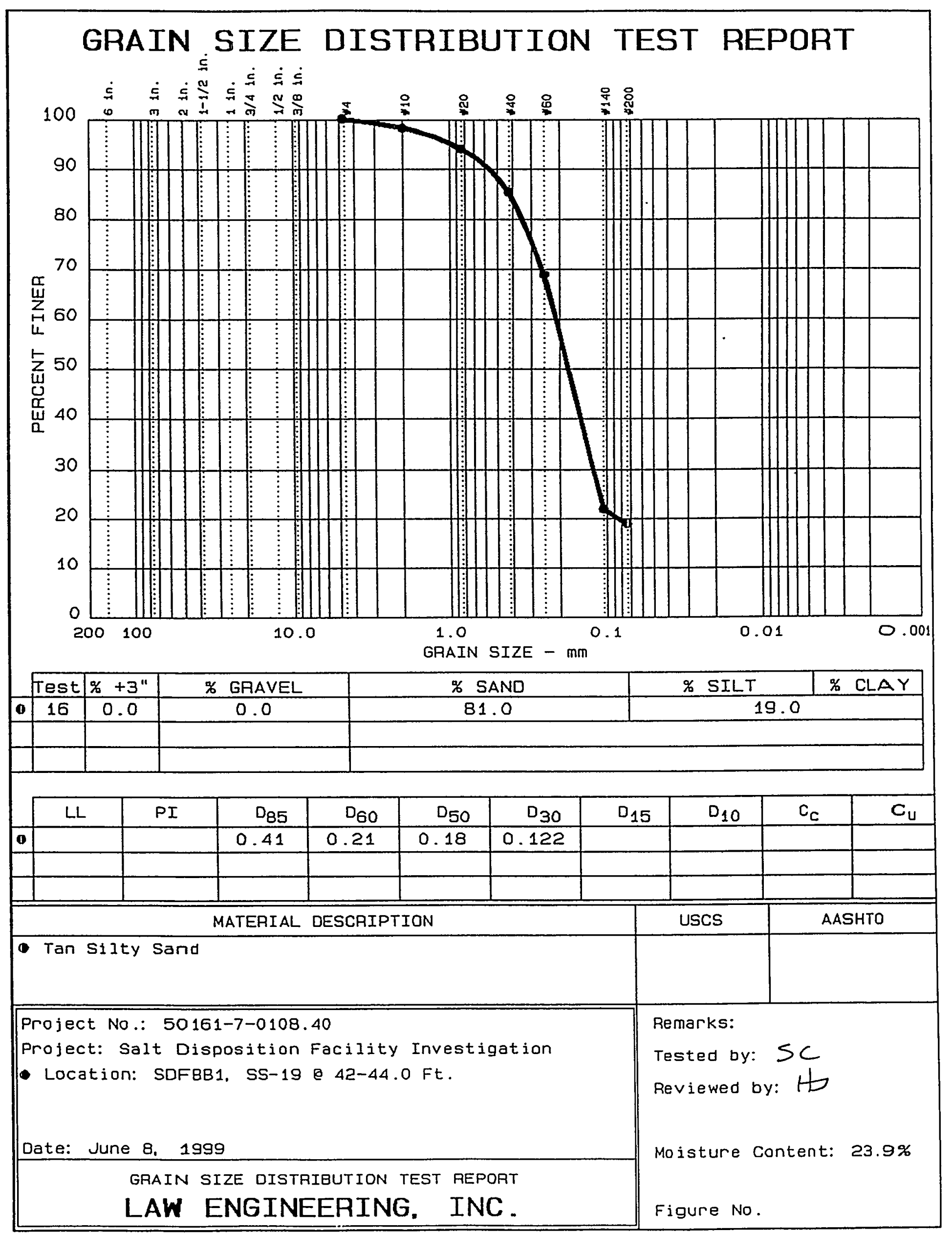




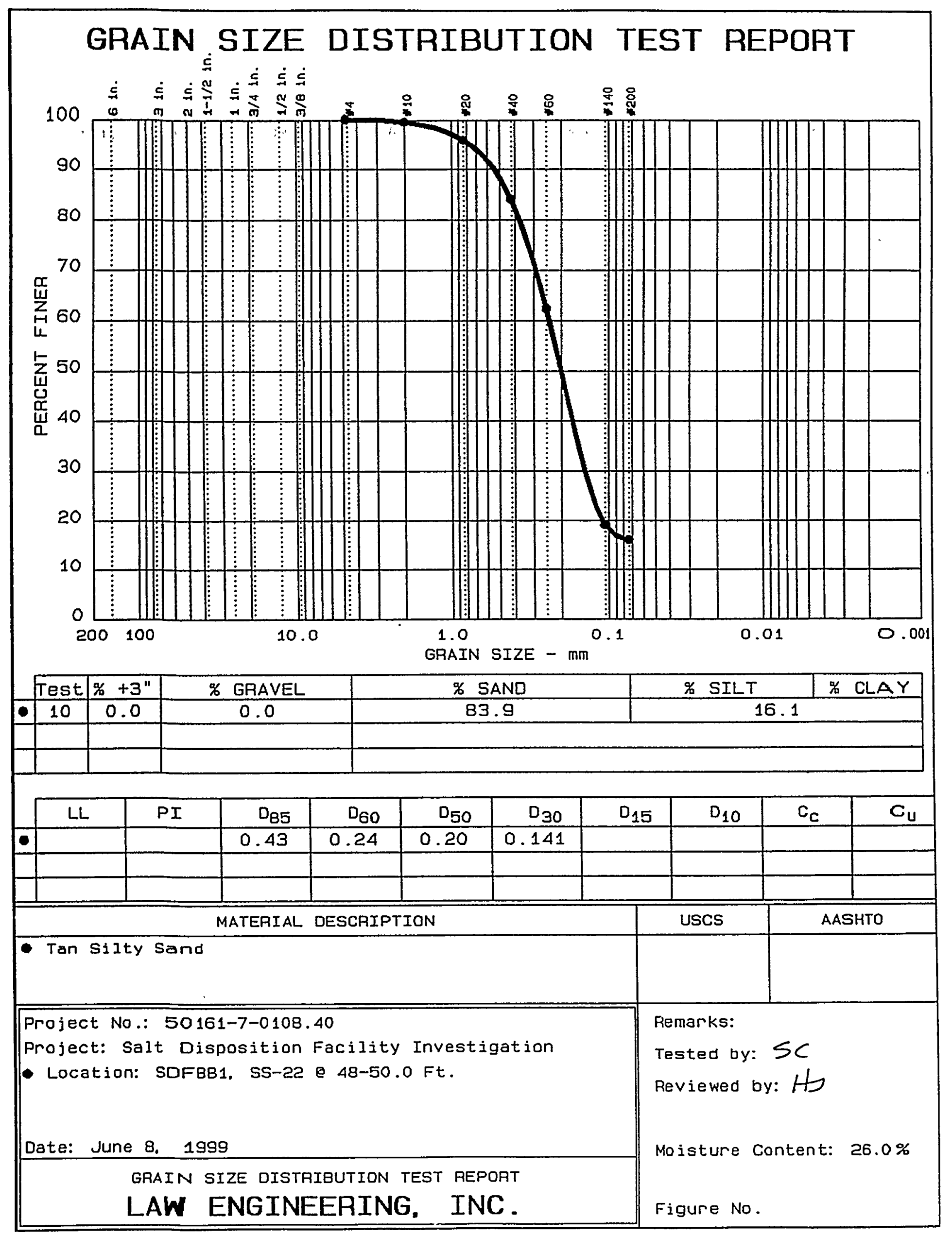




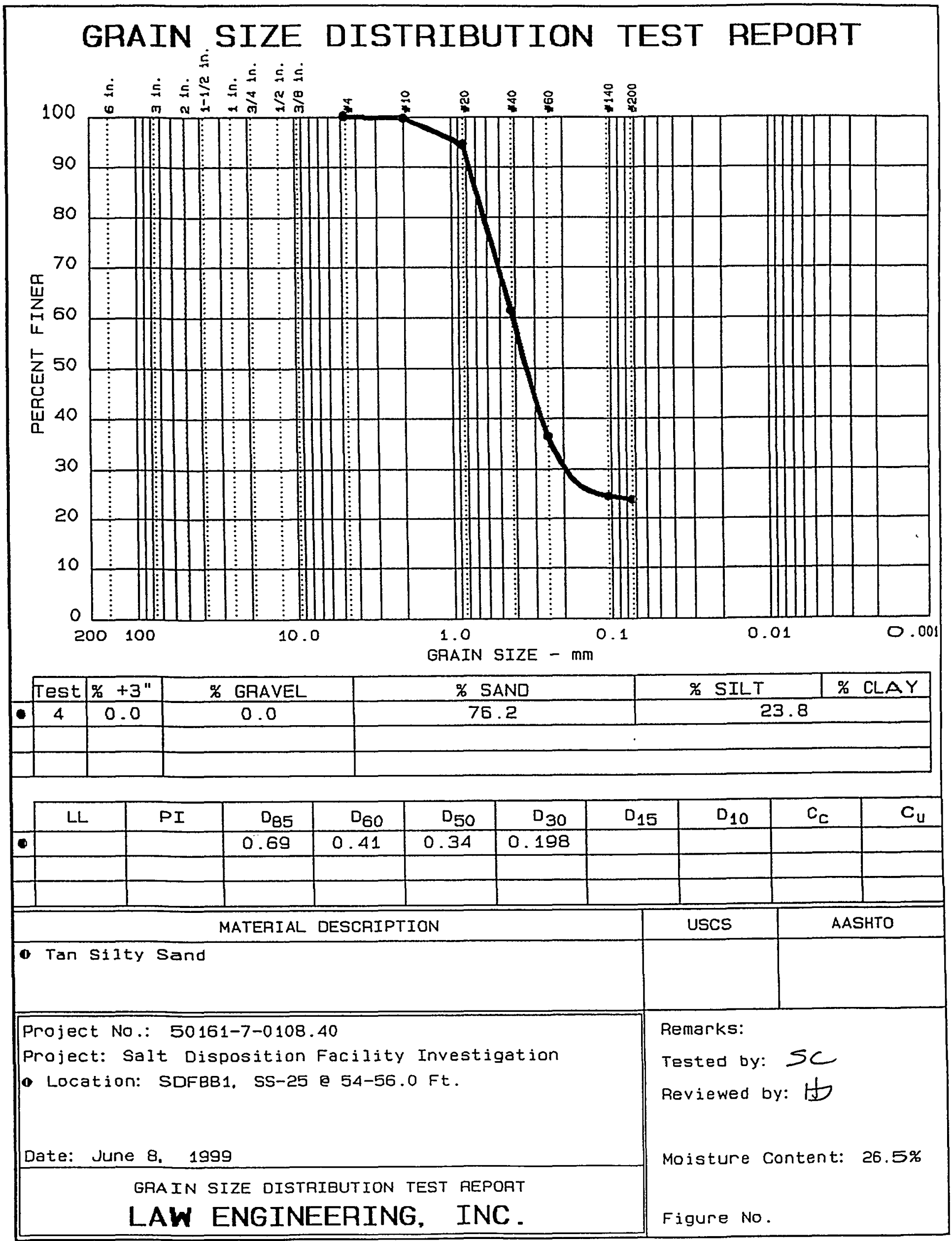




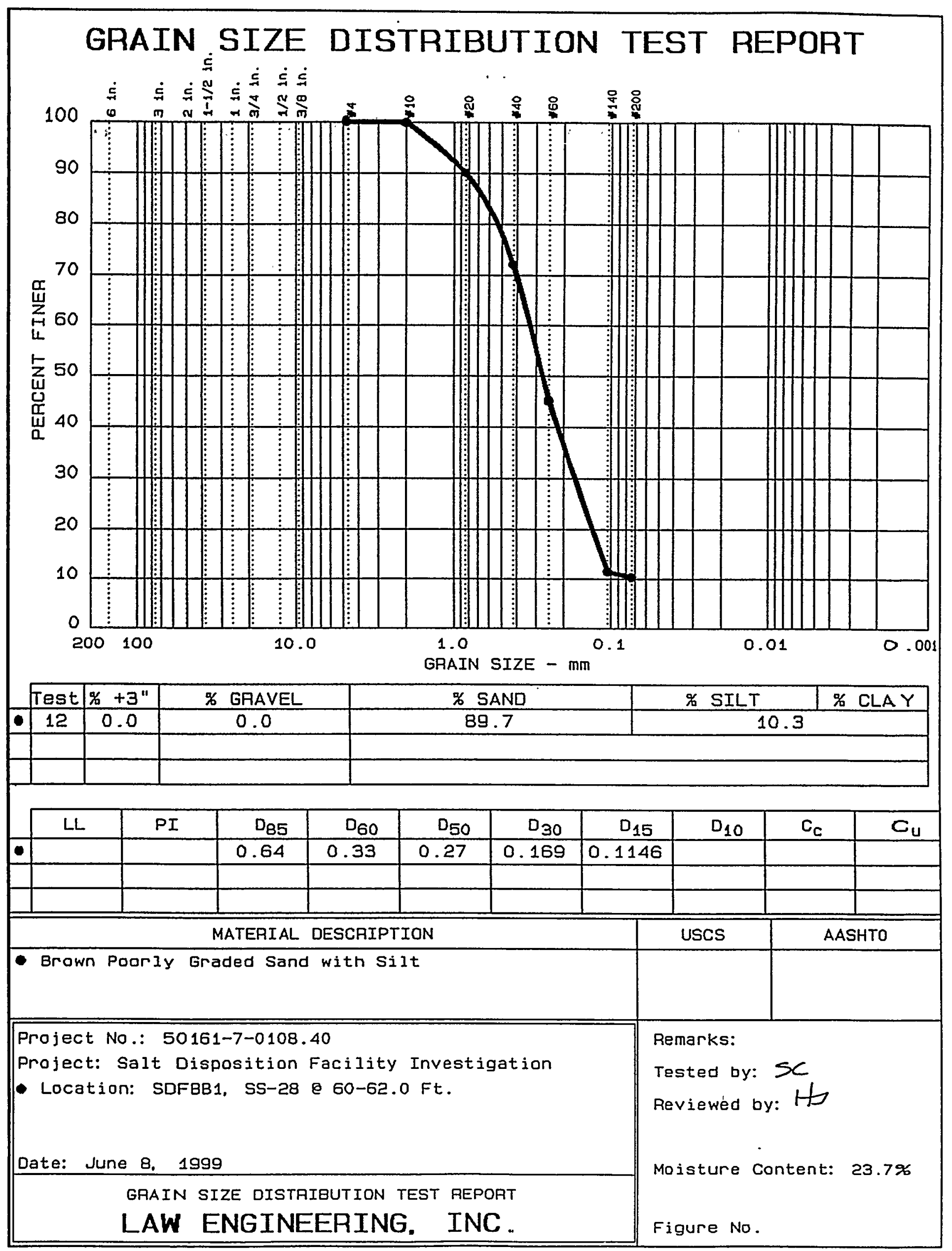




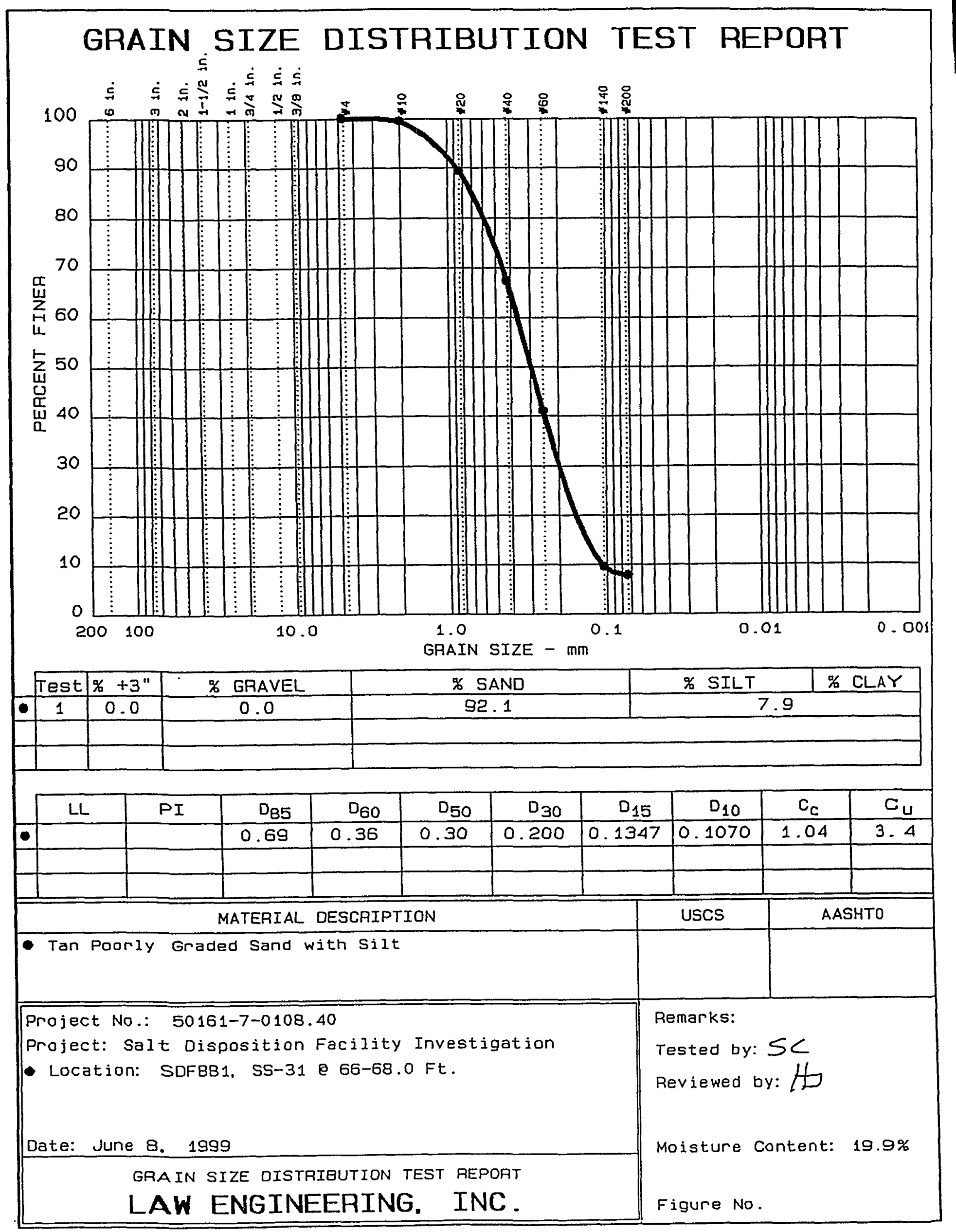




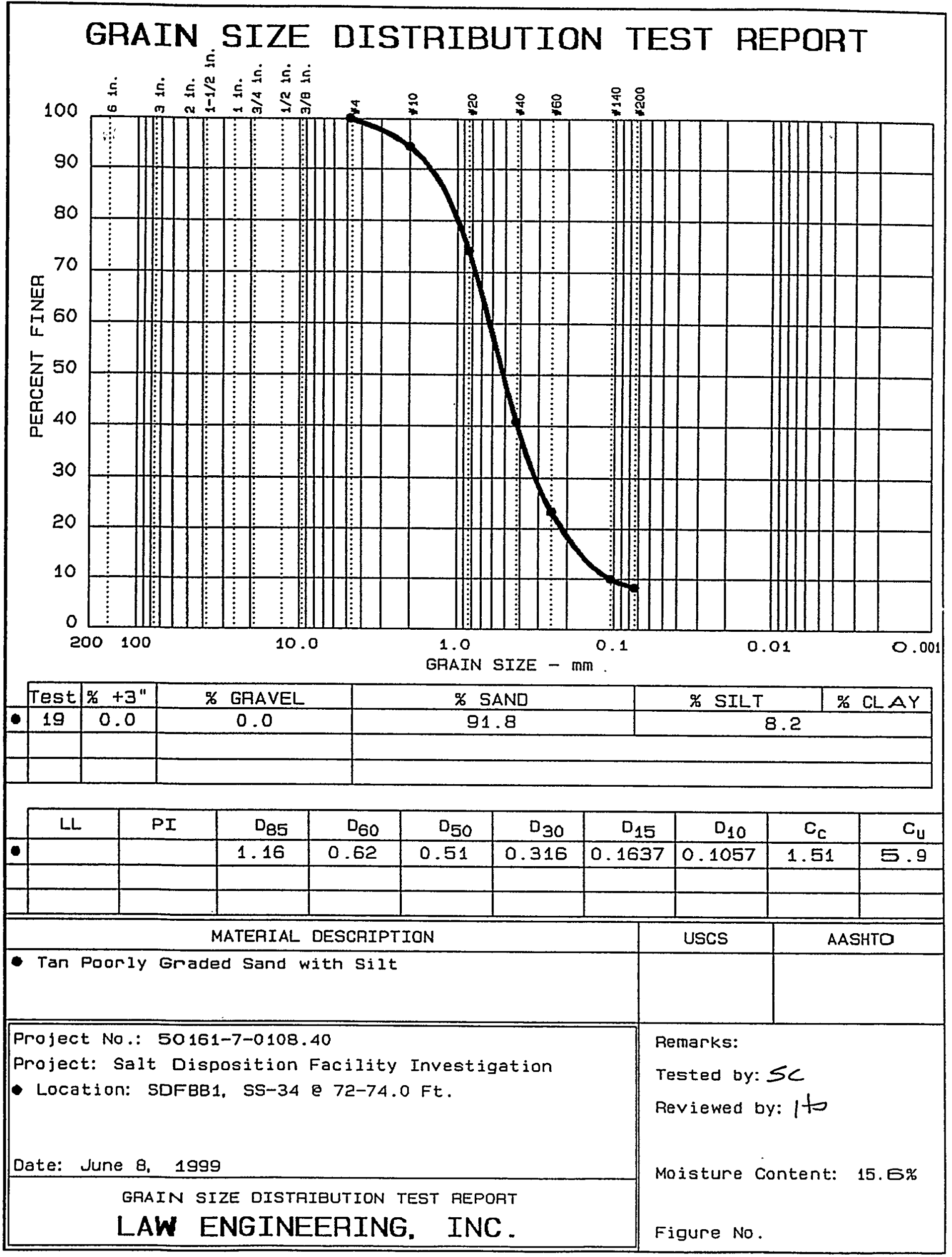




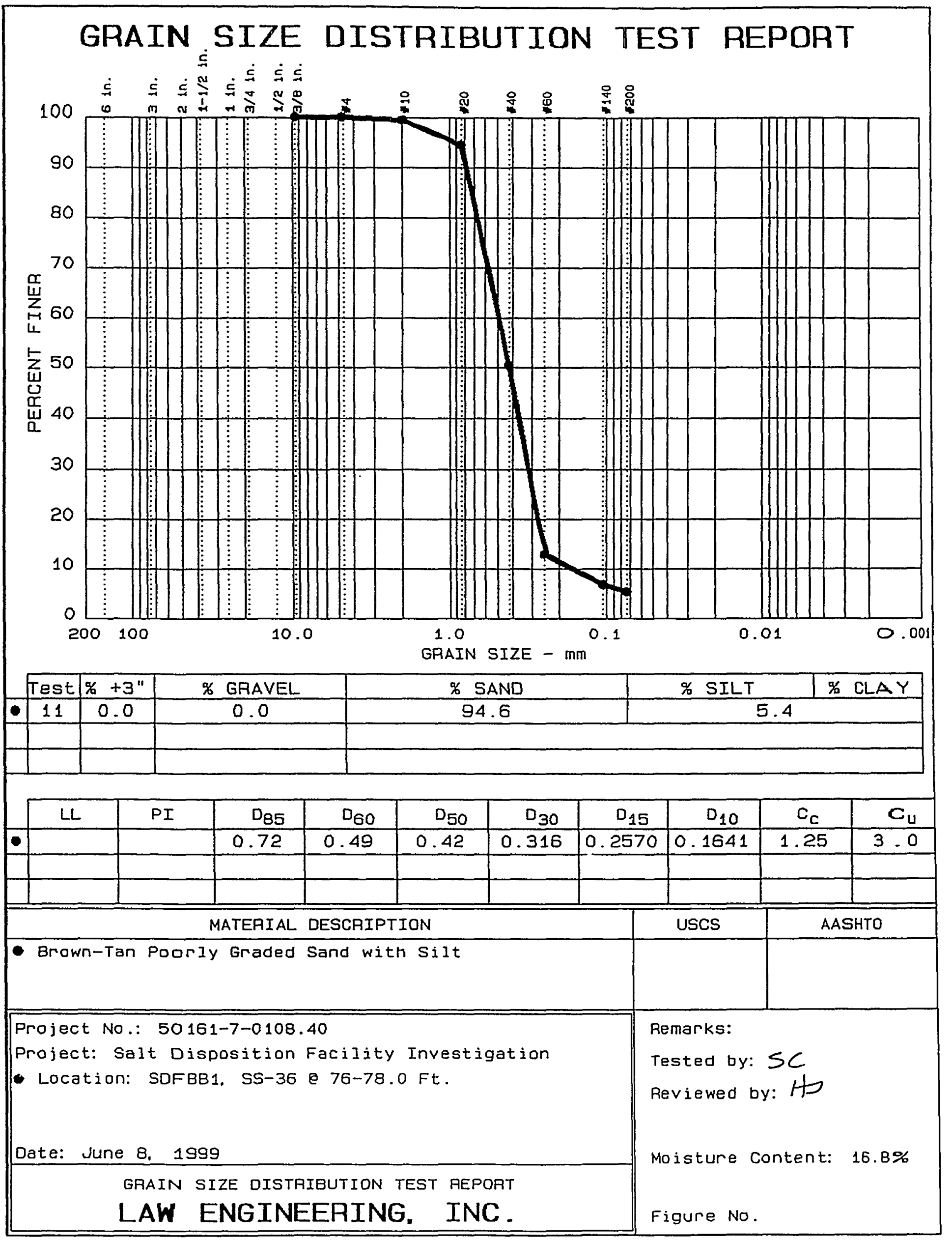




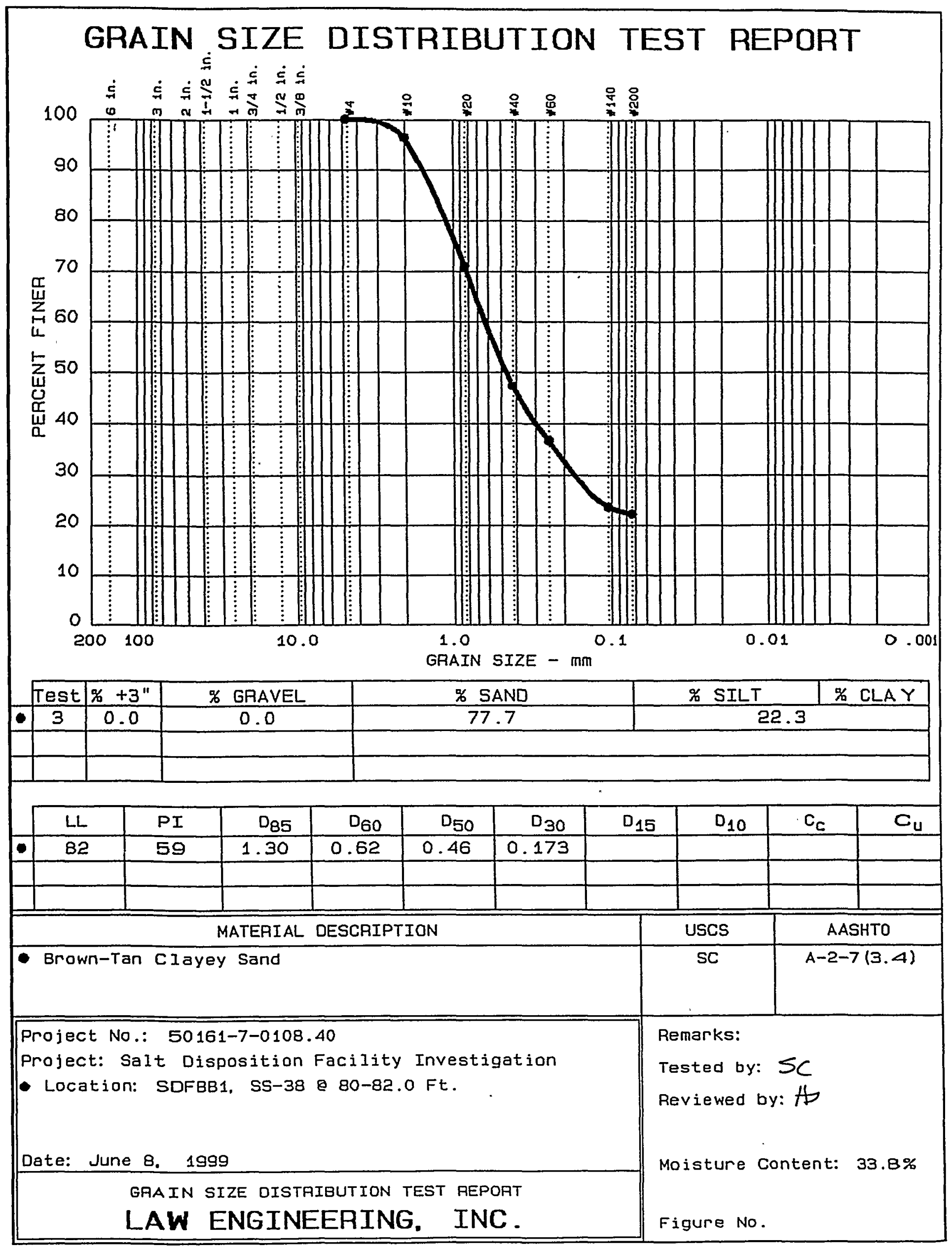




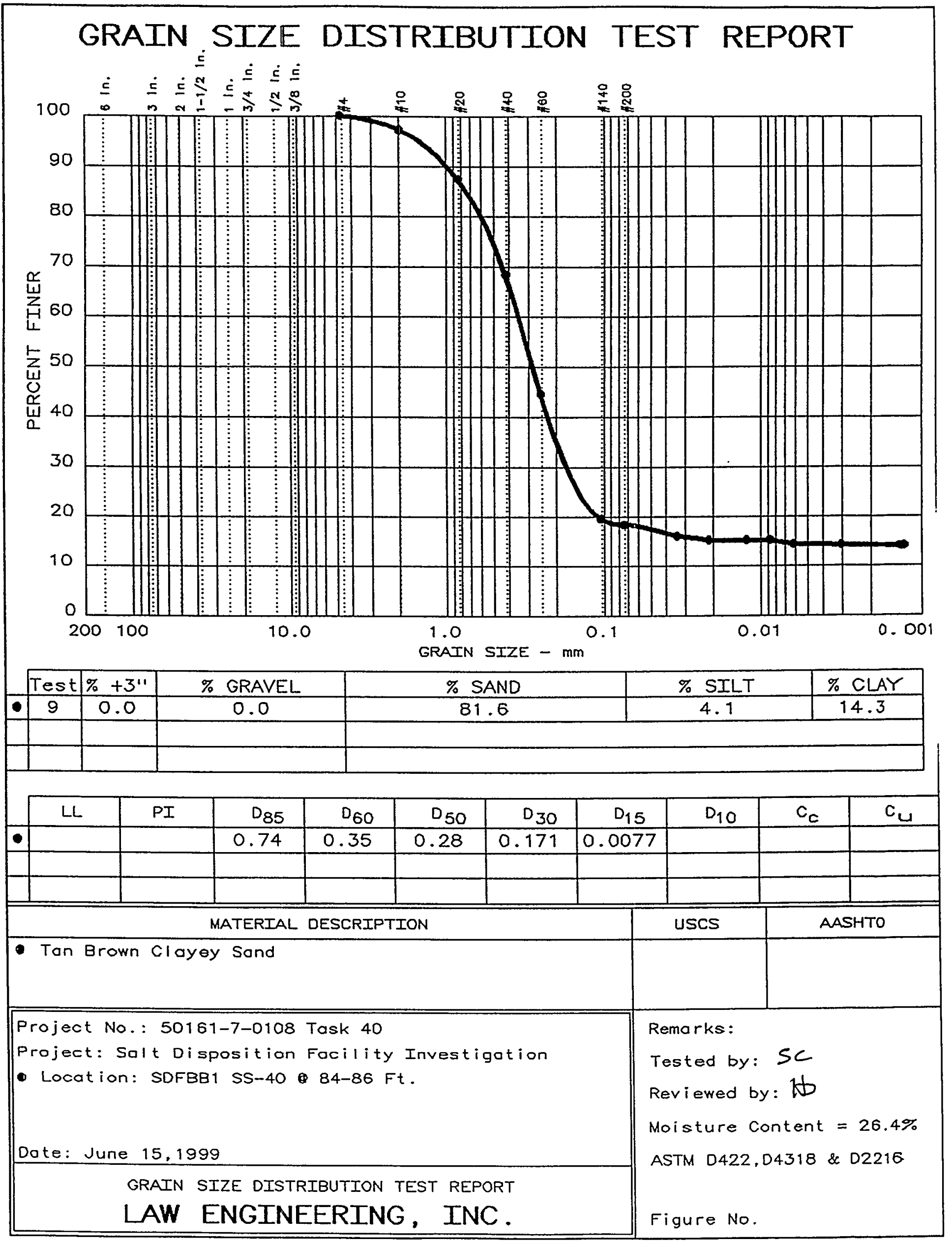




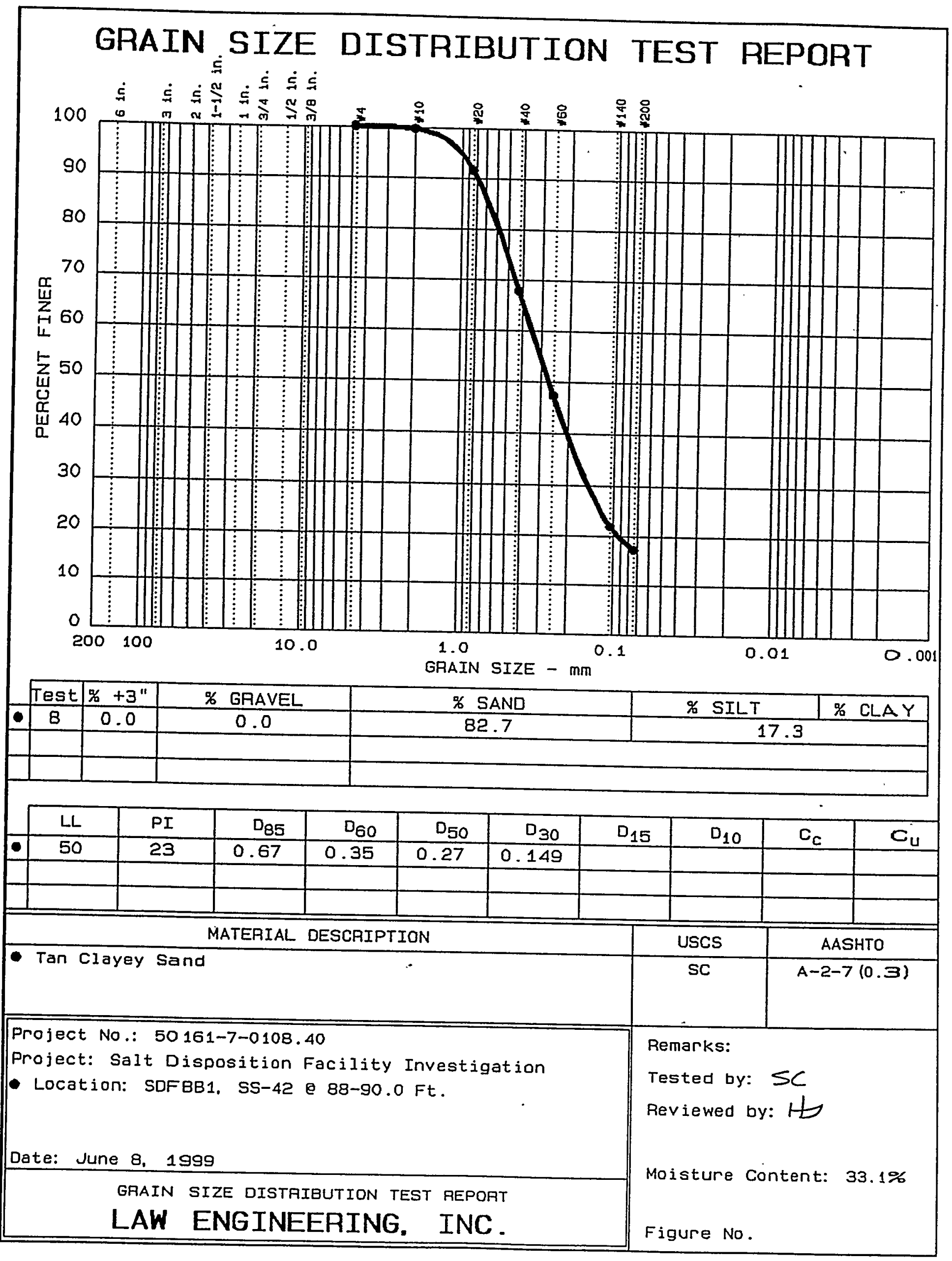




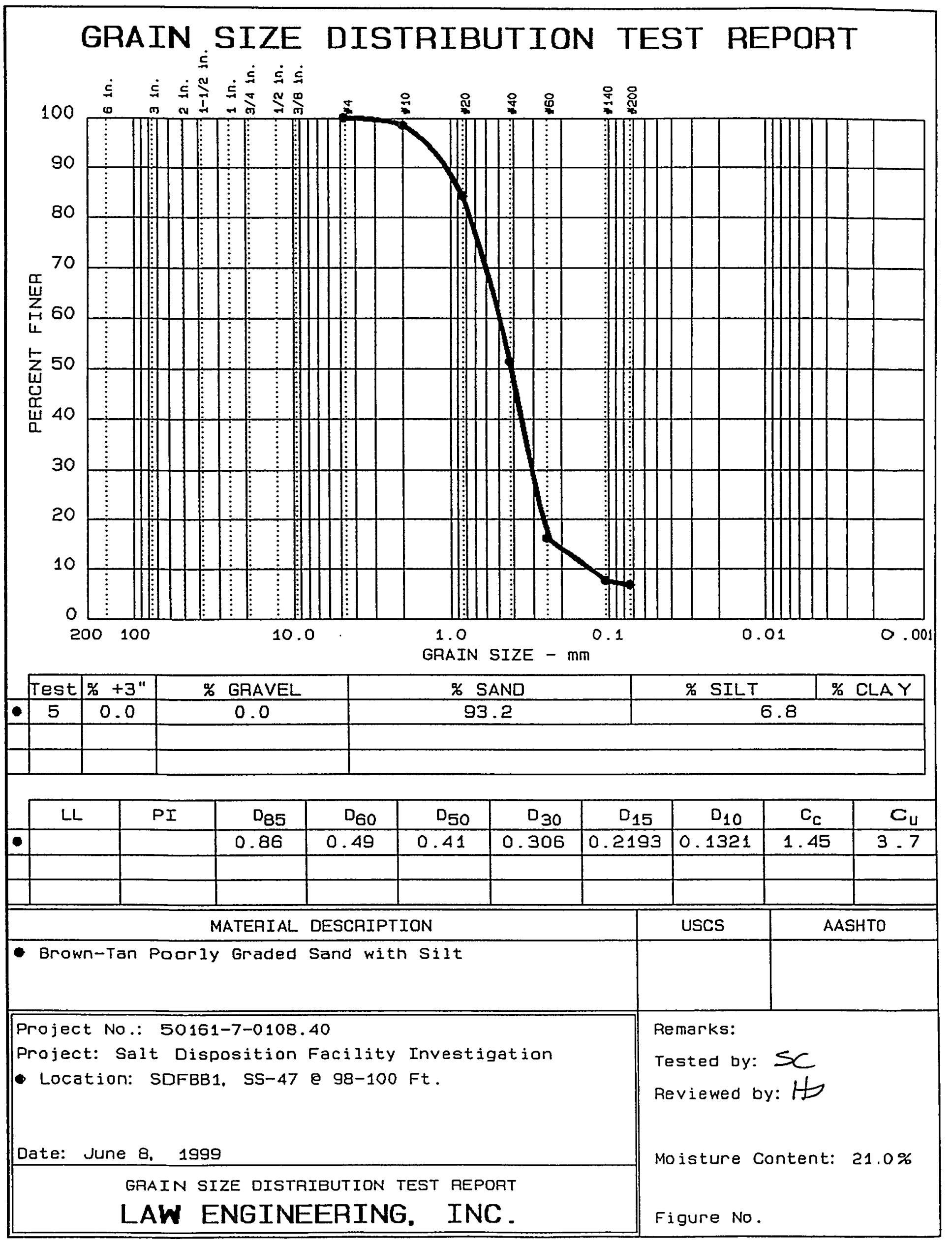




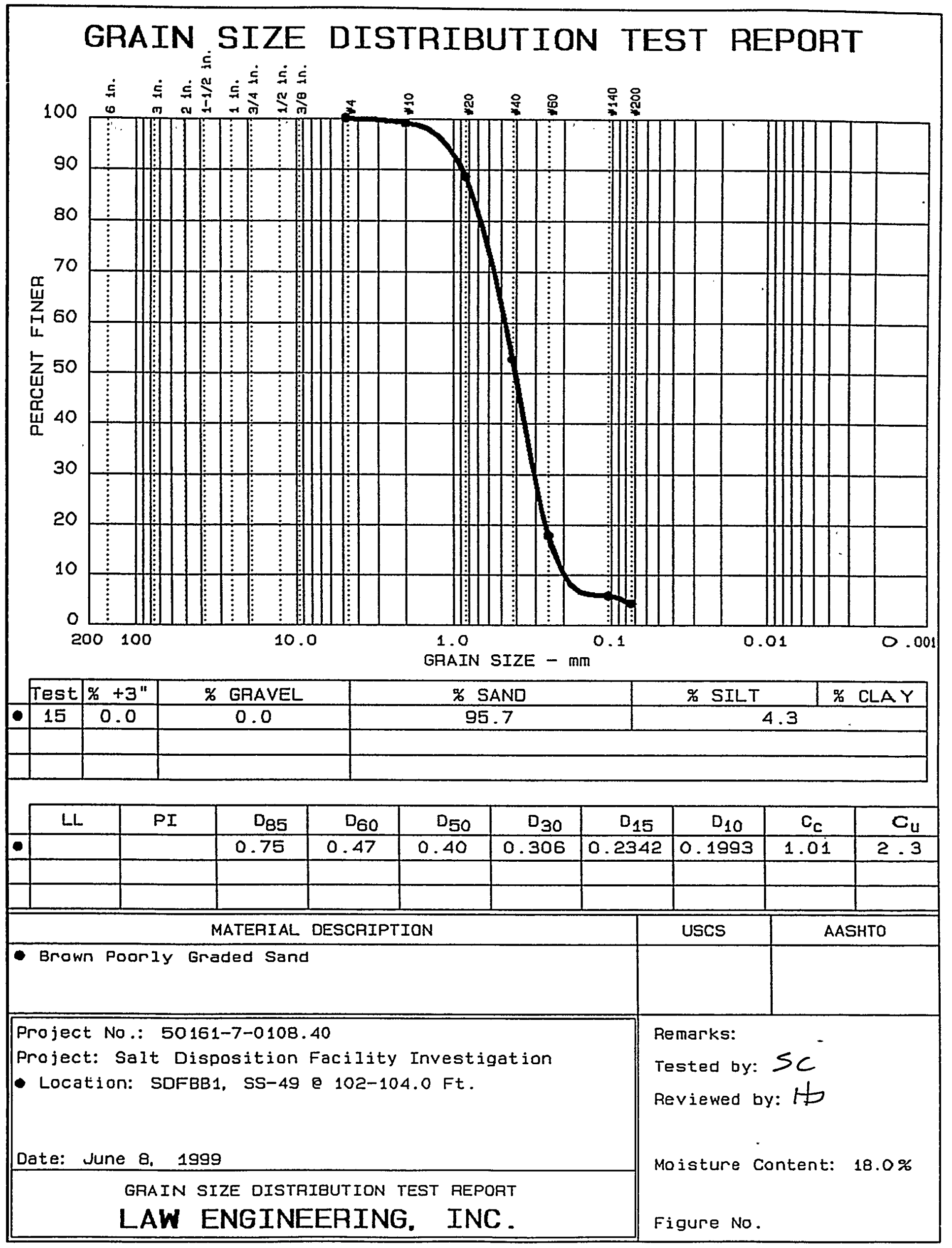




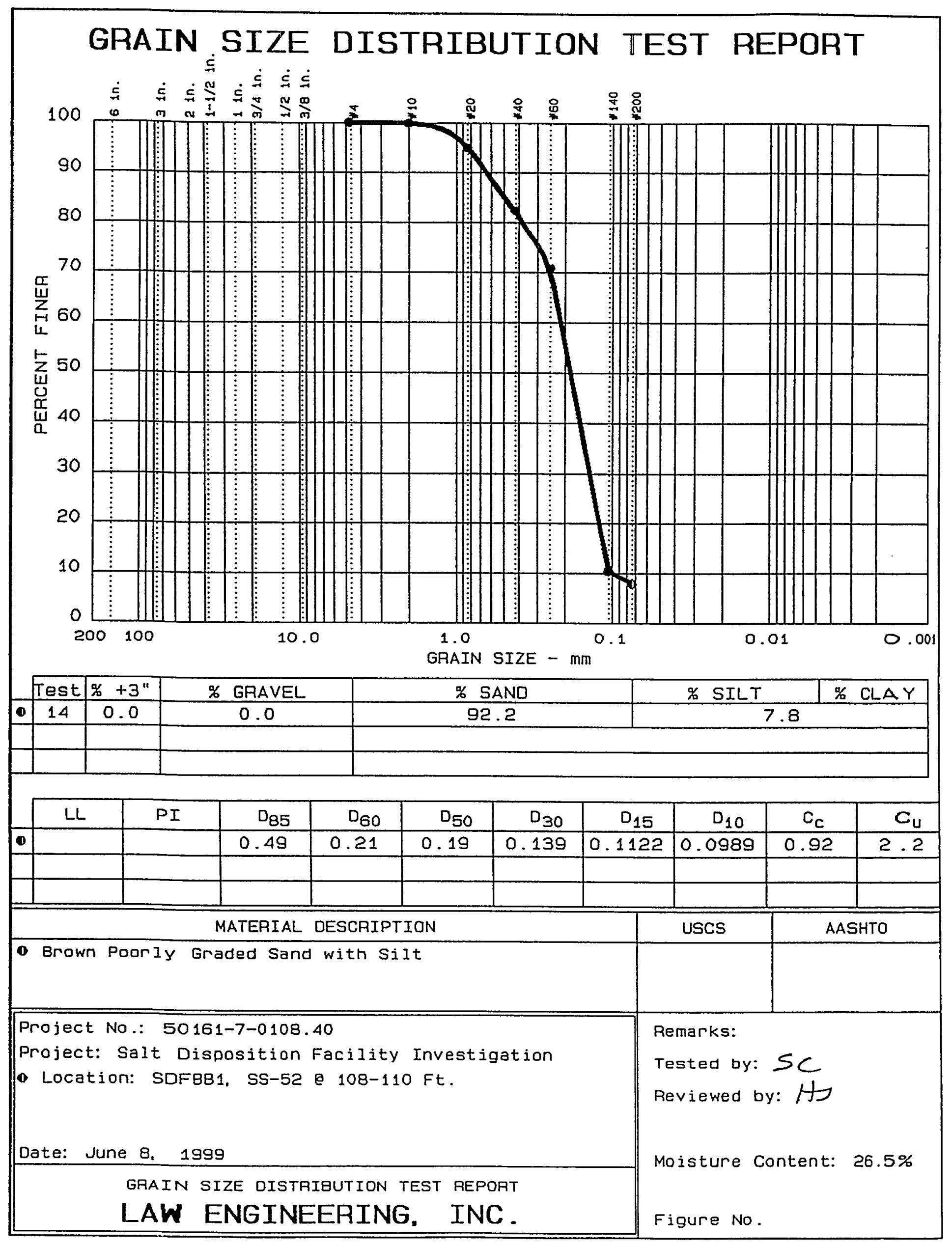




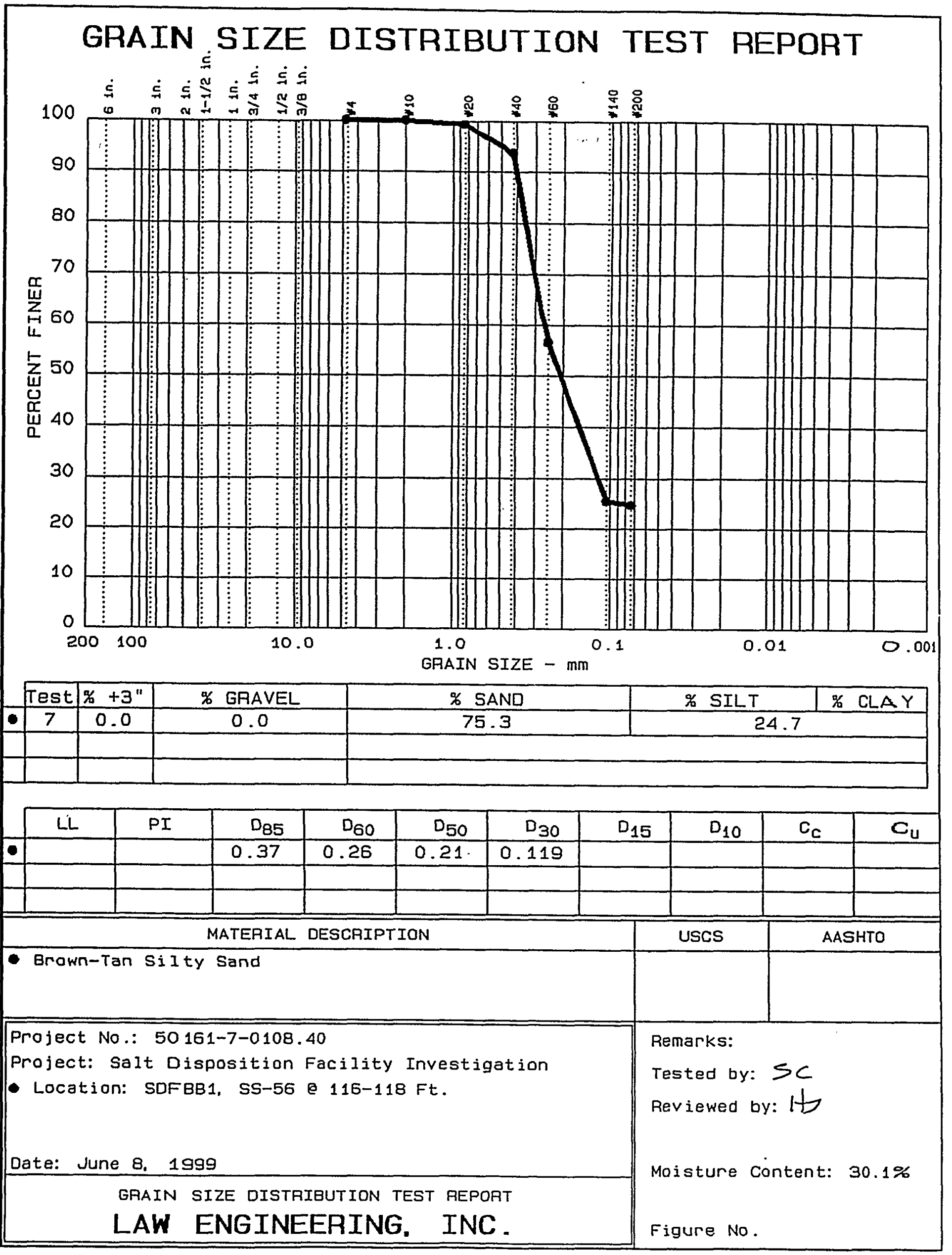




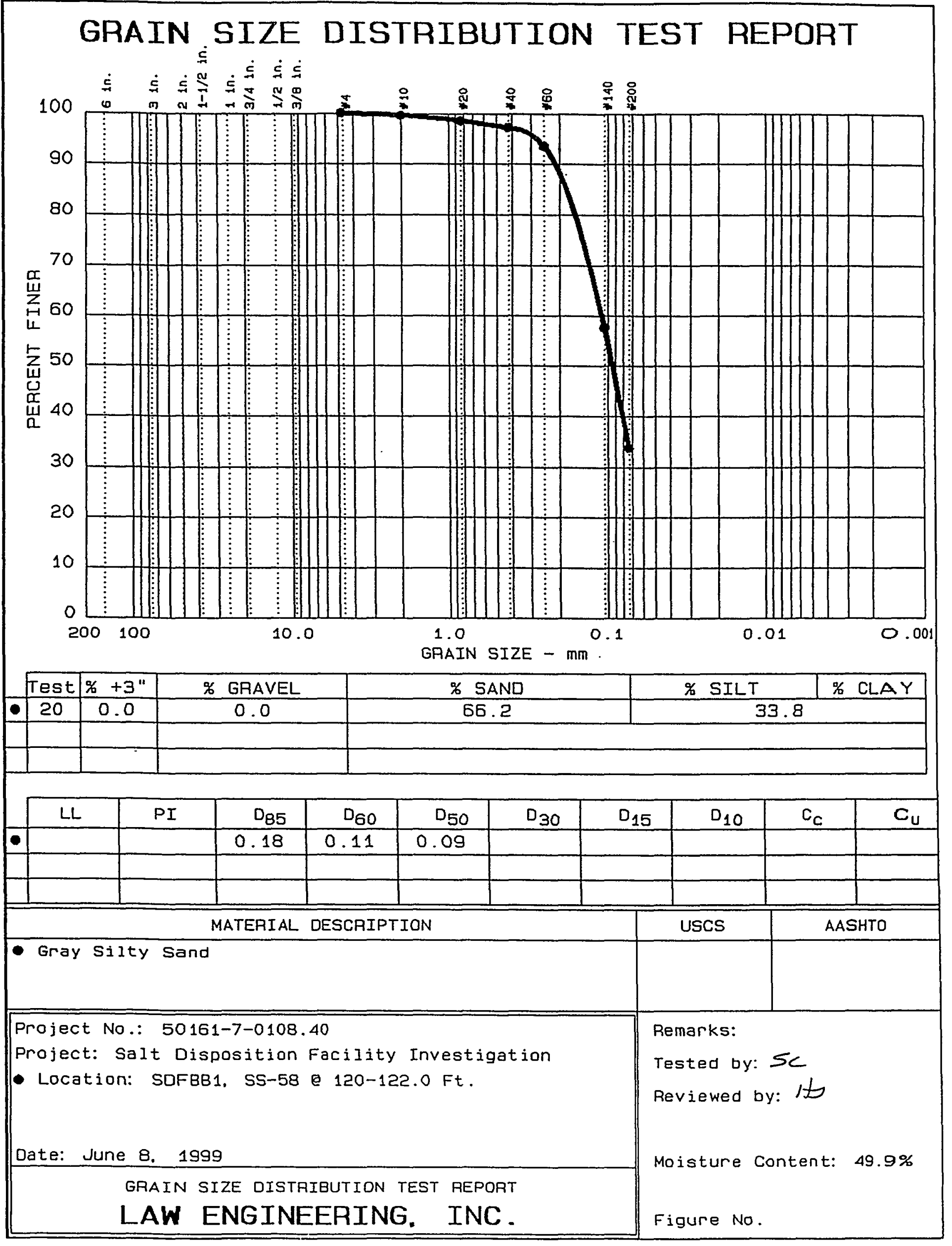




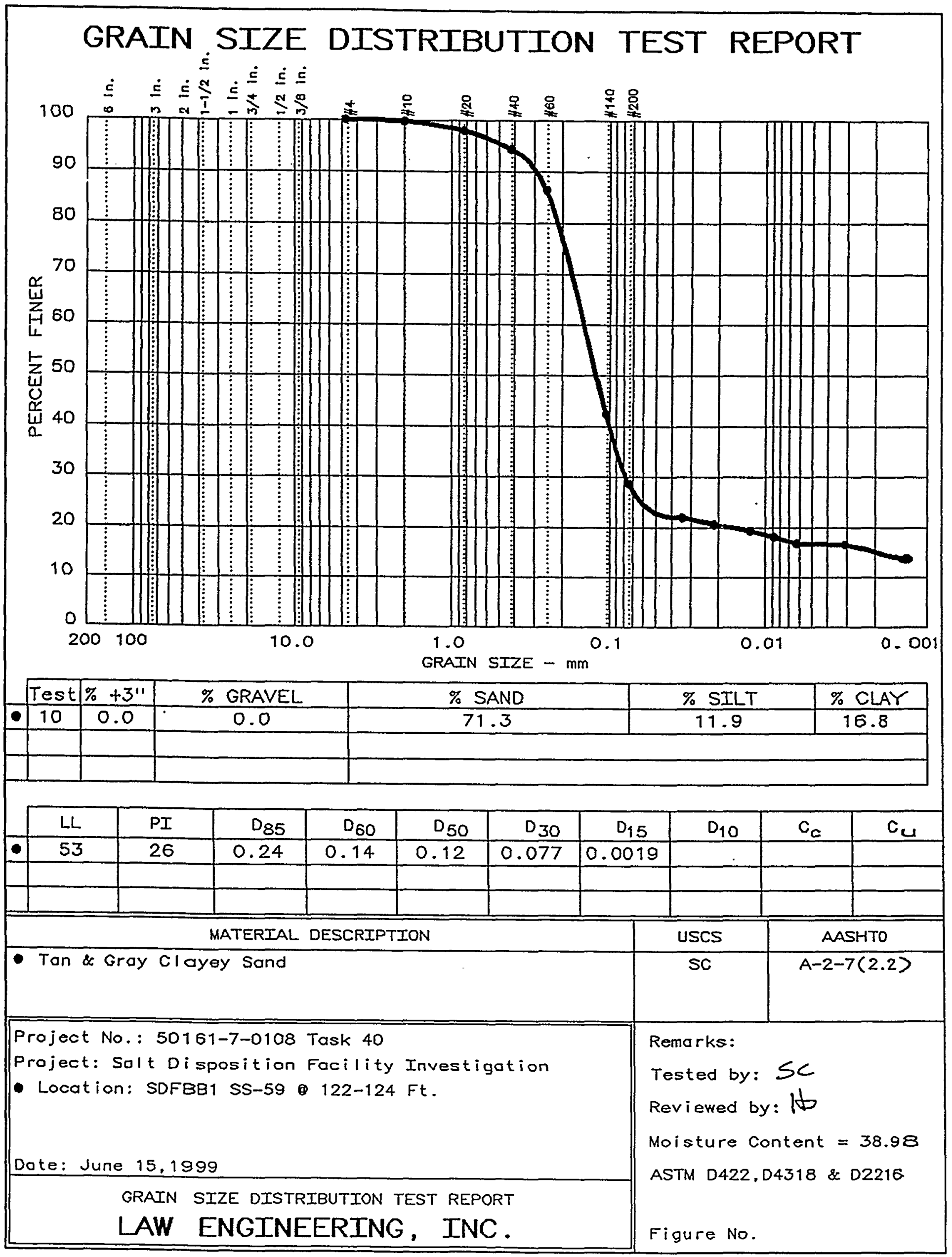




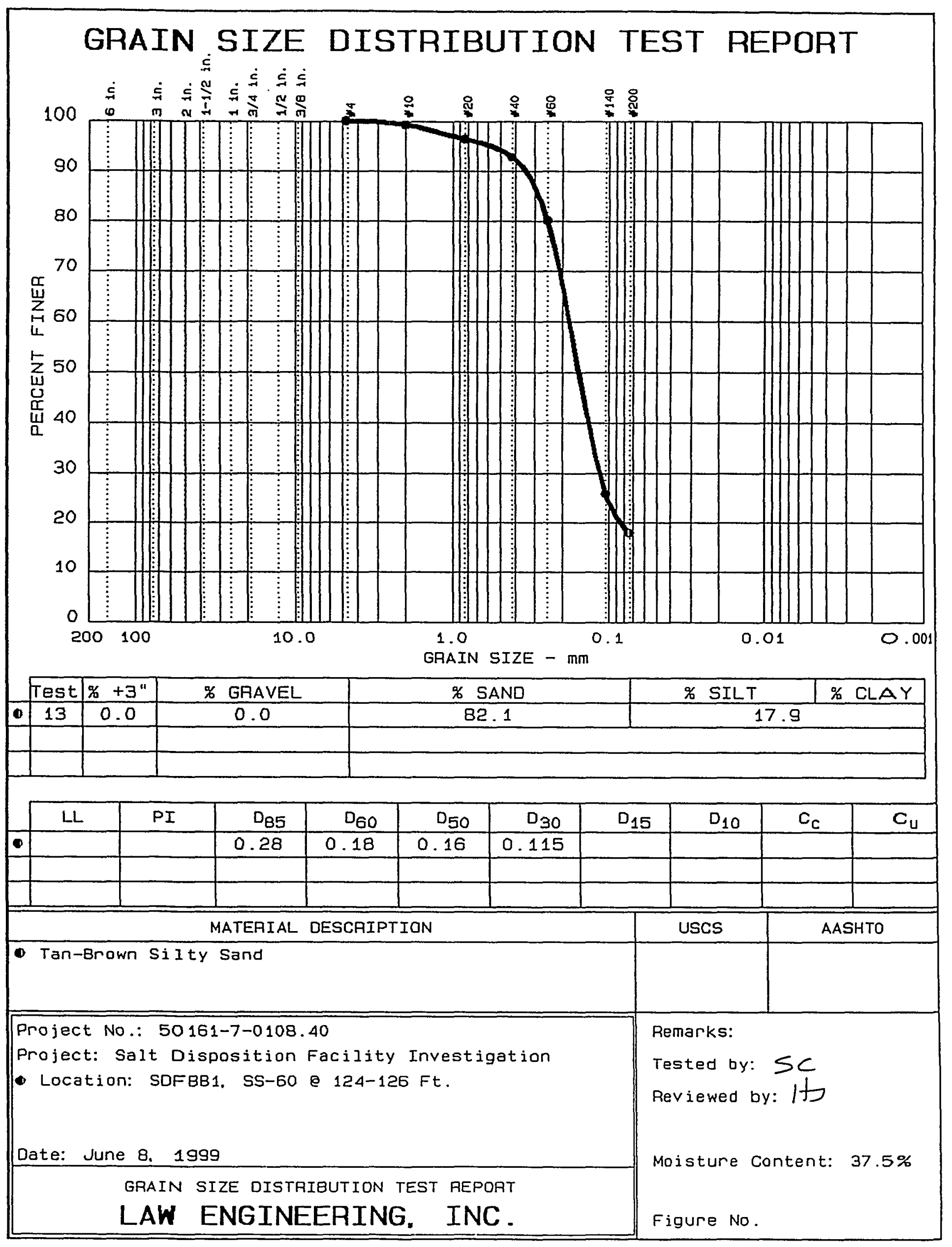




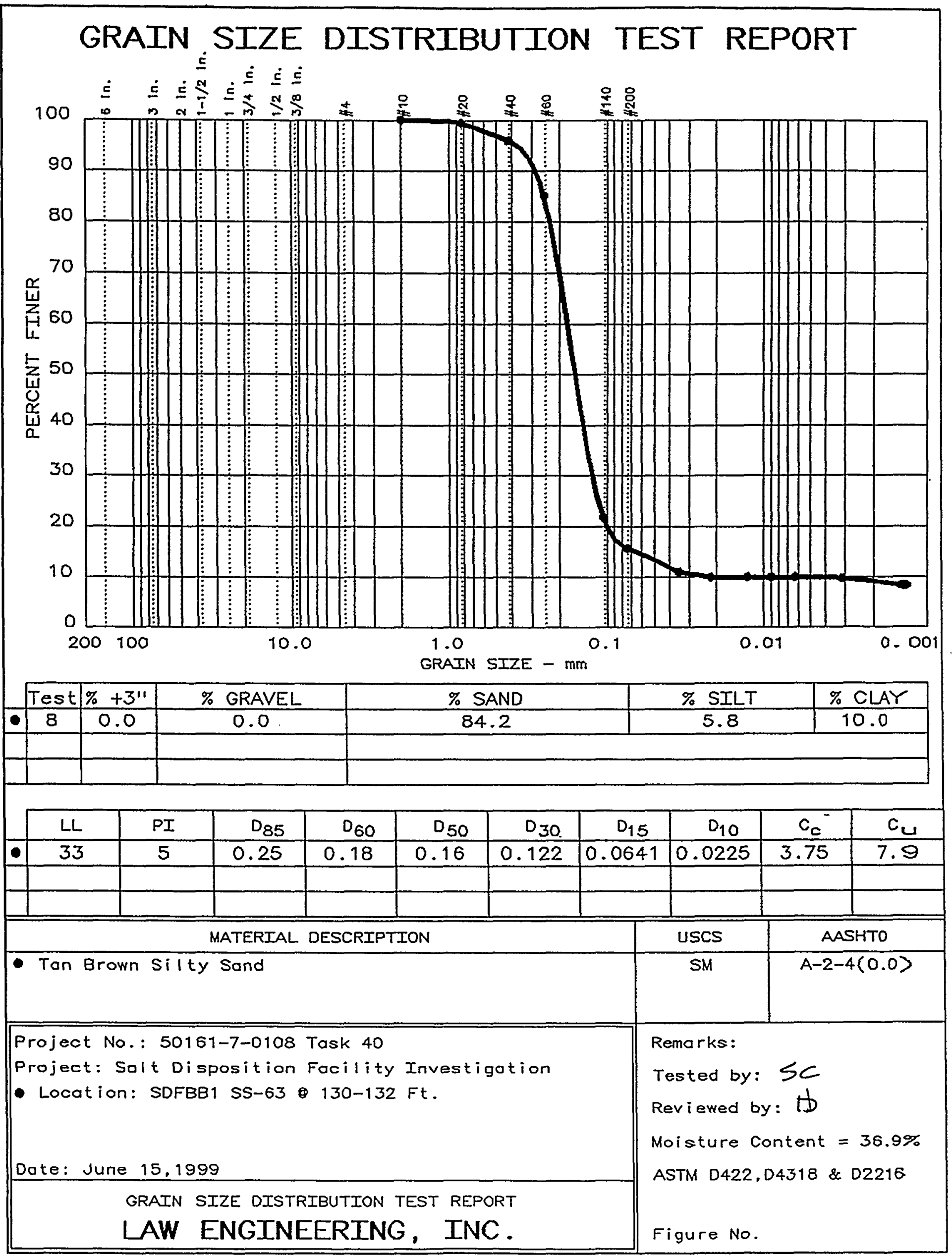




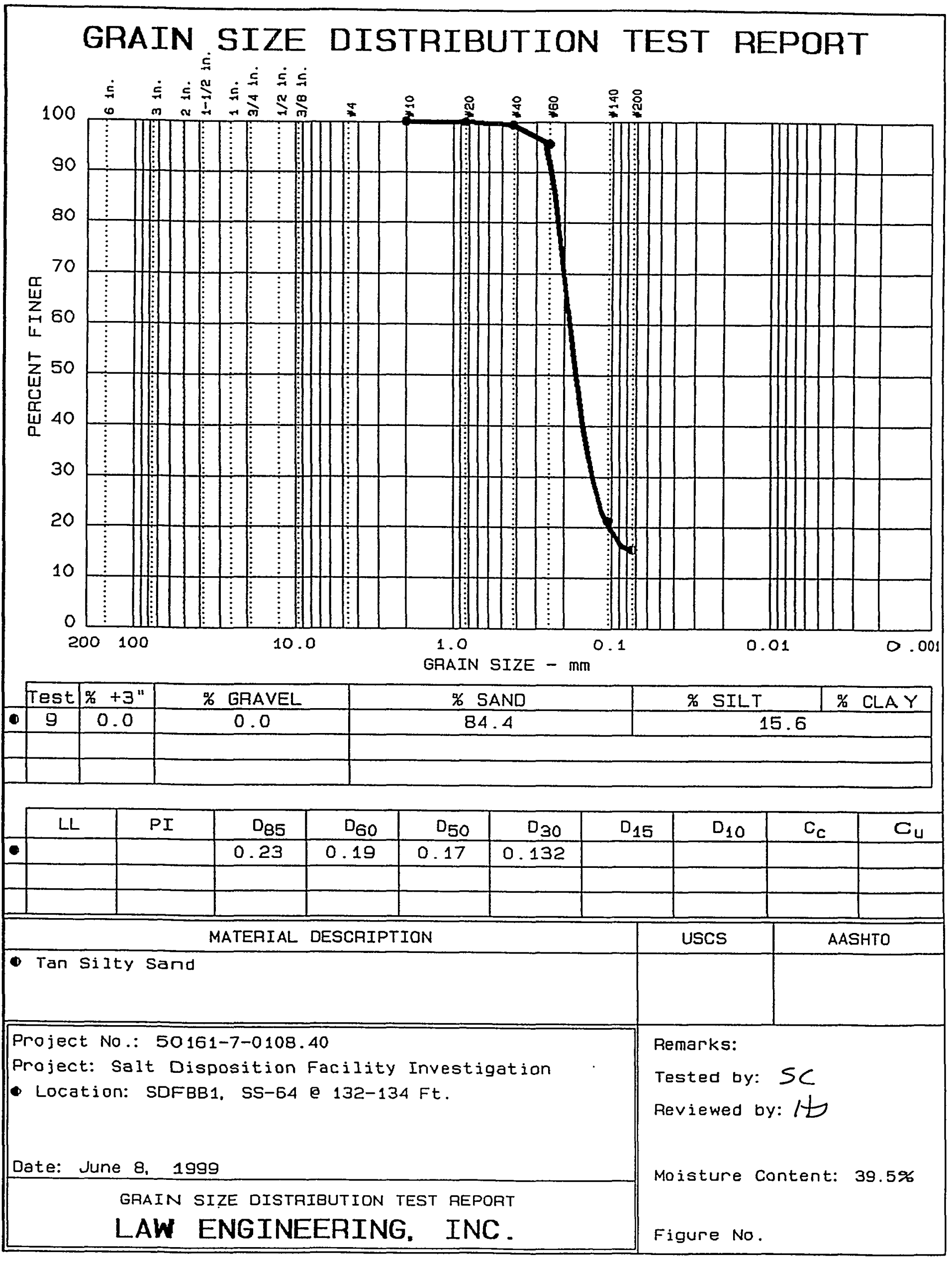




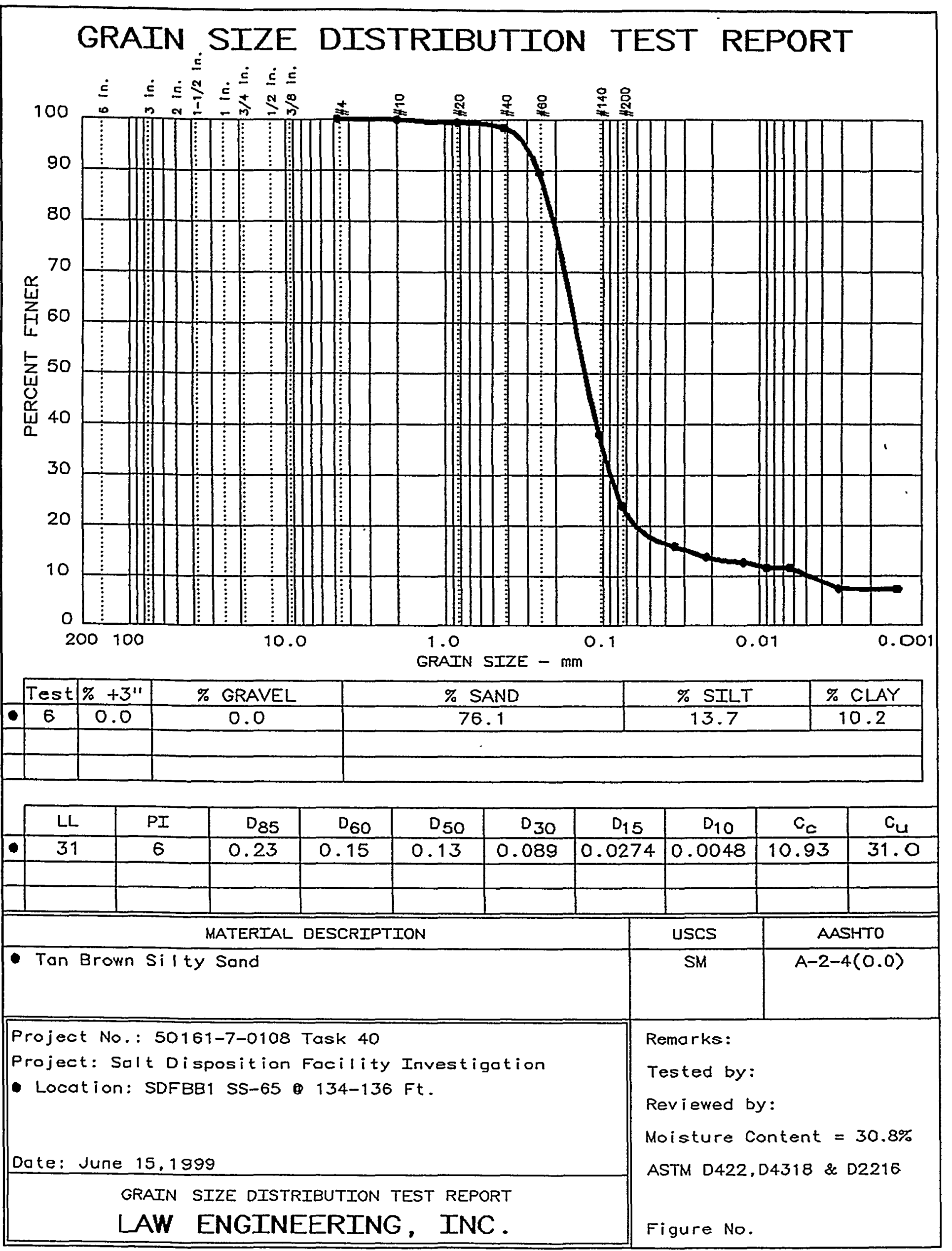




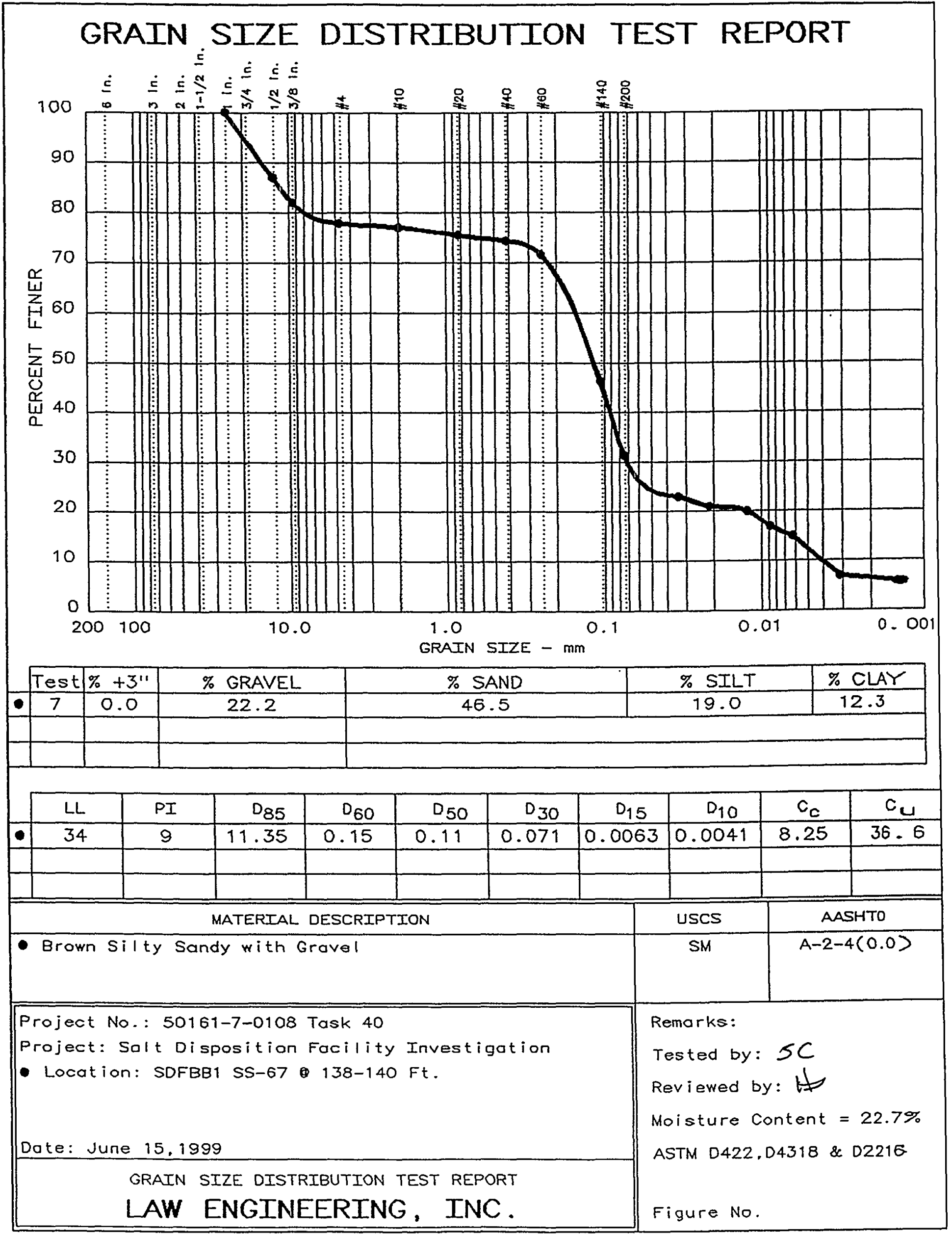




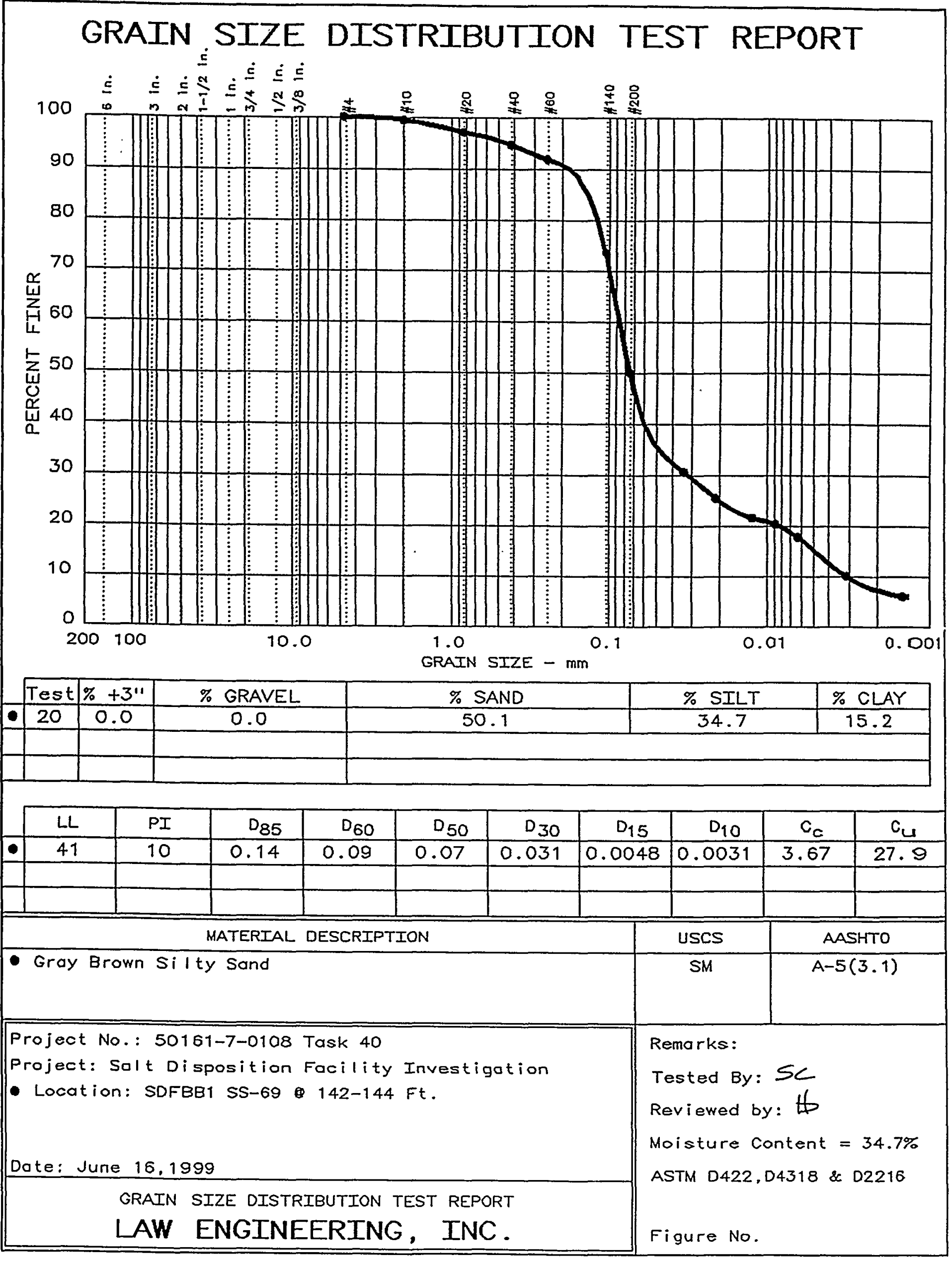




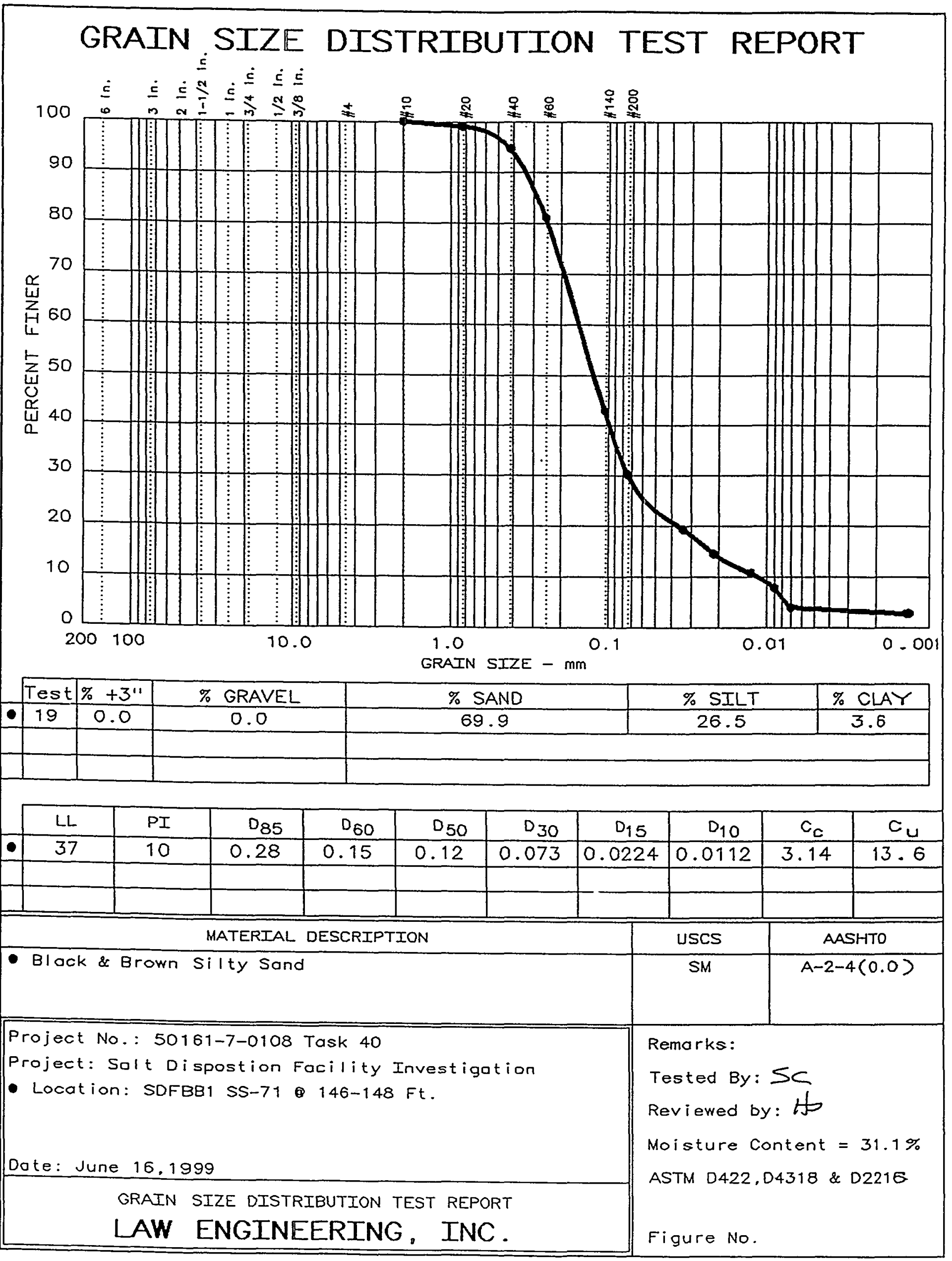


Appendix E

Groundwater Analysis Results 
This page intentionally left blank. 
Author: John02 Young at SRCCA14

Date: $6 / 23 / 99 \quad 4: 12$ PM

Normal

Receipt Requested

TO: Doug wyatt at SRCCB10

Subject: Groundwater Survey - VOA AnaTysis ResuTts

for your files

Forward Header

Subject: Groundwater Survey - VOA Analysis ResuTts

Author: John02 Young at SRCCA14

Date: $5 / 14 / 99$ 9:29 AM

SRT-ADS-99-0174

ADS has completed analysis of your 5/13 sample submission for volatile organic Analysis that was obtained during the site evaluation for the ITP Replacement Facility. The analyses were completed using a

low-level method that was developed for the Inactive process sewer

Line (IPSL) project. This compound specific selected ion monitoring

GC/MS method was used with a performance based method tuned to

optimaliy provide data at your prescribed action levels.

FuT7 range calibration for trichlorofluoromethane (Freon-11) was established and an analytical reference standard was prepared at a concentration of $20 \mu \mathrm{g} / \mathrm{L}$. This standard was fortified with the action levels $(5 \mu \mathrm{g} / \mathrm{L})$ of the other target compounds reported. This standard mix was used to establish calibration accuracy on a daily basis at the action levels for the target compounds.

In addition to the target compounds 7isted below, no other (non-target) compounds were detected in the data.

ADS\# Cust ID

3-127506 SDF-BBI-CP-45 duplicate target compound concentration, $\mu \mathrm{g} / \mathrm{T}$ (ppb) Benzene Freon11 CC74 TCE PCE

$\begin{array}{lllll}<1 & <1 & <1 & <1 & <1 \\ <1 & <1 & <1 & <1 & <1\end{array}$

where:

Freonil - trichlorofluoromethane

CC14 - carbon tetrachloride

TCE - trichloroethene

PCE -. tetrachloroethene

Samples reported with uncertainty values are calculated as the average of duplicate determinations, with the estimated uncertainty computed from the difference between the duplicates as described in standard Methods, 17th edition, section 1-15. Samples with non-detected compounds are not reported with uncertainty values.

Startup qualifications for Taboratory control blanks and calibration verification standards were within the acceptable ranges for each of the calibrated, reported compounds.

Please note that this laboratory is not certified by the south Carolina Dept of Health and Environmental Control for the purposes of generating data that is required to demonstrate compliance with a specific permit. The data is qualified for the purposes of establishing your knowledge of the process or facility. Any data from this laboratory that is available or submitted to DHEC must be qualified as originating from a non-certified $7 a b$. 


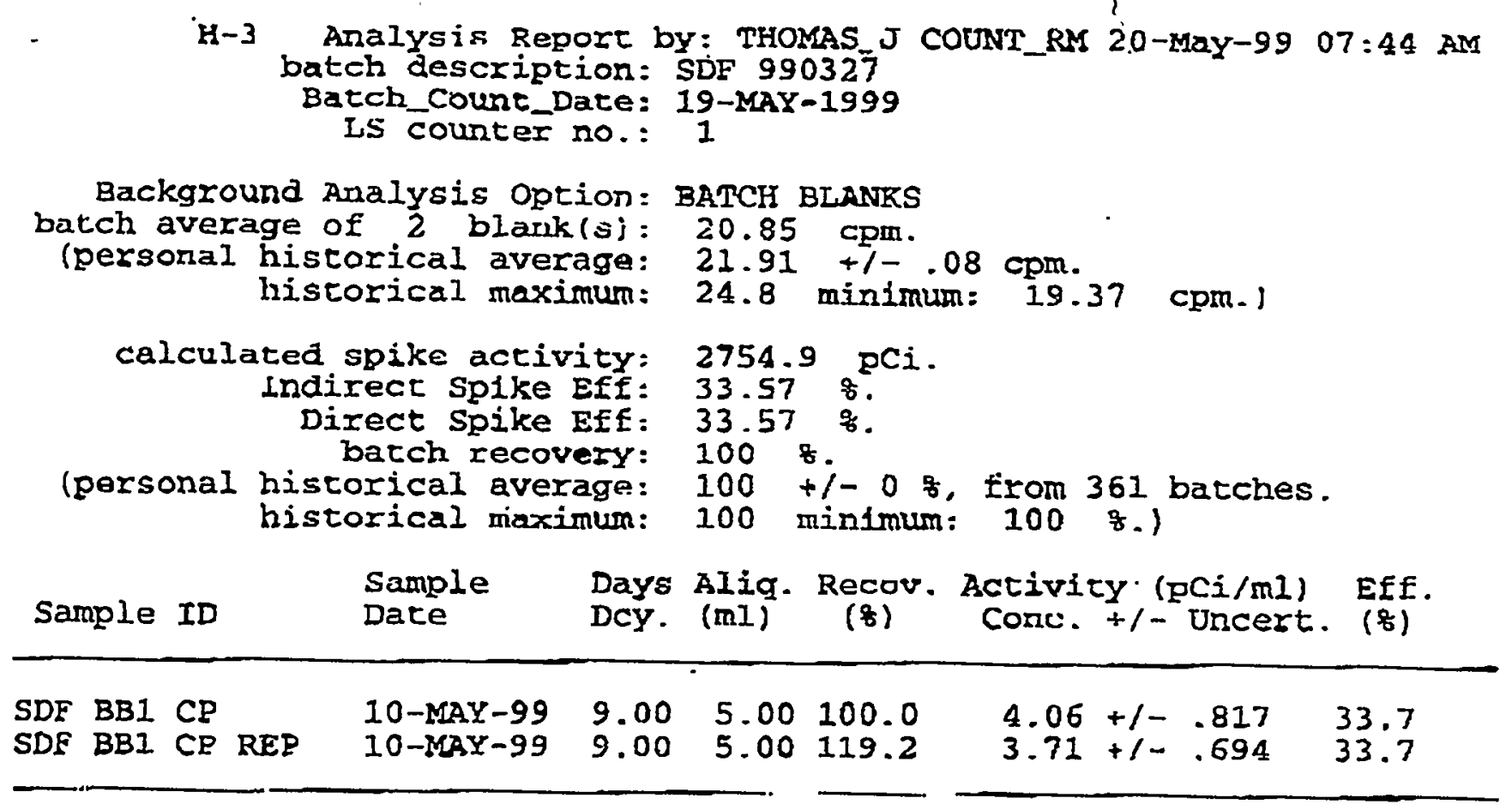

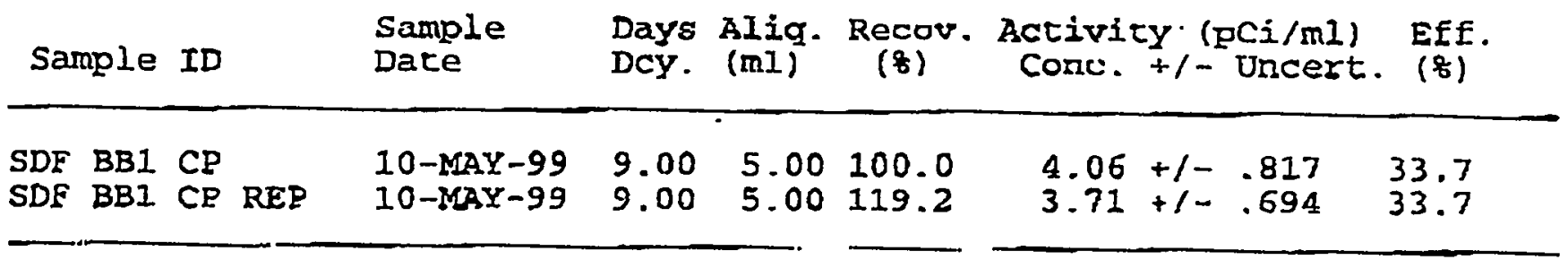

$\overline{10} \cdot$ Doug Wyatt

From. J. Jansen

Tod

not7erodroj soy $\forall[\varepsilon: 60 \quad 66-92-\kappa e w$ 